
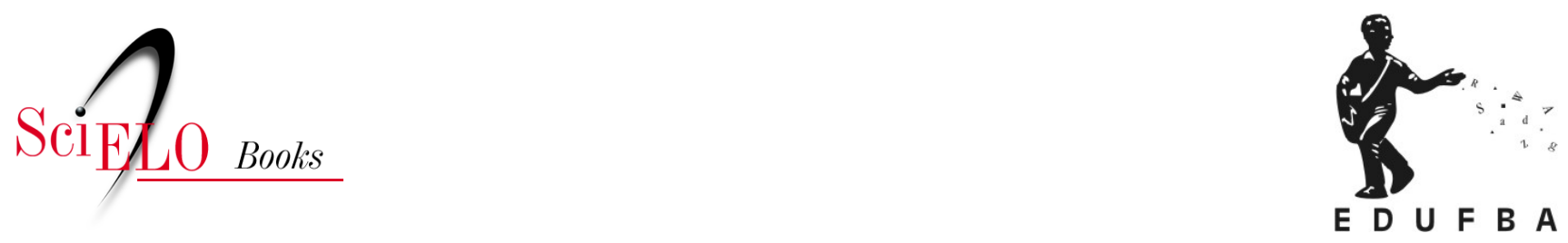

\title{
Diplomas e Decás \\ Identificação Religiosa de Membros de Classe Média no Candomblé
}

\author{
Luciana Duccini
}

DUCCINI, L. Diplomas e decá: identificação religiosa de membros de classe média no candomblé [online]. Salvador: EDUFBA, 2016, 275 p. ISBN 978-85-232-2011-2.

https://doi.org/10.7476/9788523220112.

All the contents of this work, except where otherwise noted, is licensed under a Creative Commons Attribution 4.0 $\underline{\text { International license. }}$

Todo o conteúdo deste trabalho, exceto quando houver ressalva, é publicado sob a licença Creative Commons Atribição $\underline{4.0}$.

Todo el contenido de esta obra, excepto donde se indique lo contrario, está bajo licencia de la licencia Creative Commons Reconocimento 4.0. 


\section{Diplomas e Decás}

Identificação Religiosa de Membros de Classe Média no Candomblé 
UNIVERSIDADE FEDERAL DA BAHIA

REITOR

João Carlos Salles Pires da Silva

VICE-REITOR

Paulo Cesar Miguez de Oliveira

ASSESSOR DO REITOR

Paulo Costa Lima

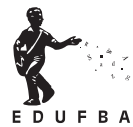

EDITORA DA UNIVERSIDADE FEDERAL DA BAHIA

DIRETORA

Flávia Goulart Mota Garcia Rosa

CONSELHO EDITORIAL

Alberto Brum Novaes

Angelo Szaniecki Perret Serpa

Caiuby Alves da Costa

Charbel Niño El-Hani

Cleise Furtado Mendes

Dante Eustachio Lucchesi Ramacciotti

Evelina de Carvalho Sá Hoisel

José Teixeira Cavalcante Filho

Maria Vidal de Negreiros Camargo 
Luciana Duccini

\section{Diplomas e Decás \\ Identificação Religiosa de Membros de Classe Média no Candomblé}

Salvador, Edufba

2016 
2016, Luciana Duccini.

Feito o depósito legal.

Grafia atualizada conforme o Acordo Ortográfico da Língua Portuguesa de 1990, em vigor no Brasil desde 2009.

CAPA, PROJETO GRÁFICO E EDITORAÇÃO

Lúcia Valeska Sokolowicz

NORMALIZAÇÃO E REVISÃO

Maria Raquel Gomes Fernandes

Bárbara Vanessa Valverde

Sistema de Bibliotecas - UFBA

Duccini, Luciana.

Diplomas e decás : identificação religiosa de membros de classe média no candomblé / Luciana Duccini. - Salvador : EDUFBA, 2016.

275 p. : il.

ISBN 978-85-232-1443-2

1. Candomblé. 2. Classe média - Aspectos religiosos. 3. Cultos afro-brasileiros.

4. Identificação (Religião). I. Título.

CDD - 299.673

Editora filiada à:

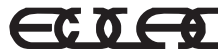

ASOCIACION DE EDITORIALES UNIVERSITARIAS DE AMERICA LATINA Y EL CARIBE
LATITAR DE AMER

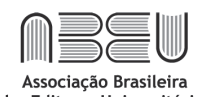

das Editoras Universitárias
$\mathrm{CBaL}$

EDITORA DA UNIVERSIDADE FEDERAL DA BAHIA

Rua Barão de Jeremoabo s/n

Campus de Ondina - 40.170-115

Salvador - Bahia - Brasil

Telefax: 0055 (71) 3283-6160/6164

edufba@ufba.br - www.edufba.ufba.br 
Às pessoas que me cederam seu tempo e suas histórias, em especial, a pai Dary. 


\section{AGRADECIMENTOS}

Muitas vezes dizemos que escrever agradecimentos é algo ingrato: com medo de esquecer alguém, fazemos uma lista infindável, da qual fatalmente esquecemos algum nome importantíssimo. Com isso em mente, gostaria de registrar meus profundos agradecimentos a todas aquelas pessoas que me concederam sua amizade nos últimos anos, mesmo que não estejam expressamente citadas. À Miriam Rabelo, minha "eterna orientadora", desejo agradecer pelos anos de trabalho dedicado, pelo instigante diálogo intelectual e pela amizade. Agradeço também a todos os professores e colegas do Núcleo de Estudos em Ciências Sociais da UFBA, pelo aprendizado e pelos anos de companheirismo em Salvador, em particular Paulo César de Brito.

Ao babalorixá Dary Paim Mota, baba Giberewá, meus mais sinceros agradecimentos por ter me aberto as portas de seu terreiro e também pelo apoio afetuoso em momentos conturbados. A todos os membros do Ilê Axé Torrundê Ajagun, sou muito grata por me terem recebido de forma calorosa, especialmente àqueles que me concederam entrevistas, gentilmente permitindo que me apropriasse de suas histórias e pontos de vista. Do mesmo modo, agradeço aos adeptos de outros terreiros que entrevistei nos últimos anos e particularmente àqueles que se tornaram amigos.

Aos muitos amigos muito queridos que, de perto ou de longe, sempre compartilharam sua força, meu muitíssimo obrigada, em especial às amigas Scyla (e toda a família) Pinto Costa Pimenta, à Sheila Cavalcante, Ivana Chastinet, Elena Calvo-Gonzalez e Gabriela Sampaio. Enfim, aos meus irmãos e cunhadas que, embora distantes, sempre me fizeram saber que encontraria seu apoio a qualquer hora e em qualquer lugar.

Ao $\mathrm{CNPq}$ e à CAPES pelas várias modalidades de bolsas, entre 2000 e 2005, que viabilizaram esta pesquisa. 


\section{Sumário}

11 Prefácio

15 Introdução

25 Uma classe média em Salvador, um terreiro do subúrbio

25 SALVADOR: CAPITAL DA BAHIA, METRÓPOLE DO NORDESTE

30 AS POLÍTICAS PÚBLICAS DE INDUSTRIALIZAÇÃO E O EMPREGO

35 A VELHA "ROMA NEGRA"

39 PARIPE E O ILÊ AXÉ TORRUNDÊ AJAGUN

51 As personagens e seu cenário: distinções de classe e estilo de vida

52 PERFIS GERAIS DAS PESSOAS ENTREVISTADAS

67 ALGUNS PONTOS DE CONVERGÊNCIA

74 QUE CLASSE MÉDIA É ESSA?

86 RENDA E EDUCAÇÃO: O QUE FAZ A DIFERENÇA?

95 Destinos e escolhas: a classe média escolarizada no candomblé

100 CANDOMBLÉ, INTELECTUAIS E CAMADAS MÉDIAS NA LITERATURA ACADÊMICA

108 A QUESTÃO DAS CAMADAS SOCIAIS E O CANDOMBLÉ

112 FORMAS DE PARTICIPAÇÃO NO CANDOMBLÉ: DIFERENTES POSSIBILIDADES DE INSERÇÃO INDIVIDUAL

128 RELIGIÃO COMO ESFERA DO IRRACIONAL: DE ONDE SE ESPERA QUE VENHA A RACIONALIZAÇÃO?

135 RACIONALIZAÇÃO E MORALIDADE

140 CONCLUSÕES PARCIAIS: CANDOMBLÉ E INDIVIDUALIDADE 
145 Orixás e projetos: identidades pessoais em trajetórias religiosas

146 OPÇÃO RELIGIOSA NUM CONTEXTO PLURAL

152 O ORIXÁ TEM TRÊS MORADAS: TEORIAS SOBRE DIVINDADES E SERES HUMANOS

162 IDENTIDADE PESSOAL E BIOGRAFIAS

172 IDENTIDADE ESPIRITUAL

181 "EU SOU FILHO DO ORIXÁ": PROCESSOS DE AUTOIDENTIFICAÇÃO

197 No terreiro: processos encarnados de autoidentificação

199 HABITUS E EMBODIMENT

208 INDUMENTÁRIA, CONVIVÊNCIA E HIERARQUIA

216 LIMPAR GALINHAS E OUTROS GESTOS DIFÍCEIS

224 INCORPORANDO HABITUS E DIVINDADES

238 PARTICULARIDADES INCORPORADAS

245 Conclusões: retomando argumentos

267 Referências 


\section{Prefácio}

Algumas pessoas tendem a confundir o valor que grupos religiosos dão a sua tradição ou origem com imobilidade e ausência de mudança. Produzem, então, uma narrativa que tem ao menos dois grandes defeitos. Torna invisíveis os esforços e investimentos implicados na defesa de qualquer tradição - esforços que, envolvendo reapropriação e retomada da tradição, nunca resultam na repetição do mesmo. E torna invisível a diversidade interna que anima qualquer religião, na medida em que ela se expande e responde a novas inquietações, novos problemas e novos desafios.

Religião de matriz africana que coloca forte peso na tradição, o candomblé foi, por muito tempo, abordado pelos estudiosos a partir de uma narrativa deste tipo. Uma breve incursão histórica mostra-nos um quadro diferente: ao longo de sua existência o candomblé consolidou um modo próprio de lidar com o sagrado, mas também muitas variações neste modo compartilhado e viu transformar-se o contexto em que atua e busca reconhecimento. Como não poderia deixar de ser, respondeu ativamente (e de acordo com seu próprio dinamismo interno) a reconfigurações na sociedade a 
sua volta. De religião fortemente perseguida ganhou espaço nos discursos oficiais sobre a identidade e cultura nacionais e galgou a posição de ator que, se ainda é vítima de forte preconceito e intolerância, dificilmente pode ter sua voz ignorada no espaço público. De religião cultuada por africanos e seus descendentes no Brasil e, em larga medida, restrita aos segmentos mais pobres da população, hoje conta também com muitos adeptos brancos e atrai gente de diferentes camadas sociais. Segundo Reginaldo Prandi tornou-se religião universal, aberta para todos.

Luciana Duccini interessou-se pela mudança no perfil dos seguidores do candomblé, mais particularmente pela participação de indivíduos de camadas médias nos terreiros de Salvador. É essa participação que ela aborda aqui. As pessoas que integraram o universo de sua pesquisa eram, em grande maioria, profissionais com formação universitária, habitantes de bairros privilegiados da cidade, cujo contato com o candomblé deu-se na idade adulta (ou final da adolescência) e representou uma ruptura com a trajetória religiosa de seus pais. O ingresso destes indivíduos em uma religião de forte valorização da ancestralidade africana desperta, sem dúvida, um conjunto de questões importantes. Como vieram a se identificar com o candomblé? Que experiências, expectativas e motivações os conduziram a esta religião? Que impacto tem o candomblé em suas vidas? Como se deu ou se dá seu aprendizado da religião e como se apropriam de seu complexo universo mítico e ritual?

Luciana costura estas questões de maneira bastante original e ao fazê-lo contribui de modo importante para renovar o campo de estudos do candomblé. Por um lado, situa-se com segurança na clássica tradição da sociologia da religião weberiana. Explora a relação entre religião e classe social recusando tanto visões reducionistas que tomam a religião como um reflexo de interesses de classe, quanto abordagens que postulam uma quase total autonomia do religioso. Ambas as posições esquecem que, se uma religião precisa responder aos anseios de seus seguidores (razão pela qual vem a ser marcada 
pelos interesses das camadas que a ela aderem), na medida em que delineia um quadro de experiência, também afeta e em alguns casos transforma de modo bastante radical a orientação subjetiva dos seus adeptos. Para Weber, o quanto uma religião logra reorientar a conduta dos fieis e atender aos seus interesses é uma questão empírica que não pode ser respondida em termos gerais: exige investigação. Luciana segue à risca essa diretiva.

Mas se o livro retoma temas clássicos da sociologia e antropologia da religião, também logra reatualizar de maneira criativa esses temas. Nas mãos de Luciana, a análise da relação entre religião e classe social se transforma em um estudo detalhado dos processos de identificação e aprendizado pelos quais indivíduos de classe média de Salvador passam a incorporar o candomblé em suas vidas e a terem nos terreiros a vivência de um mundo para o qual sua experiência de classe pouco lhes preparou. Entender esses processos, argumenta Luciana, requer atenção tanto a sua temporalidade quanto a sua dimensão corporificada: falar de ingresso em uma religião é uma maneira econômica de descrever um percurso que se estende no tempo, que frequentemente desafia esquemas corporais sedimentados e envolve uma reorganização destes esquemas.

Para tratar de uma experiência religiosa em curso, que não se faz sem ambiguidade, Luciana optou pela etnografia. Seu livro é resultado de uma etnografia fina, construída com a sensibilidade e cuidado de uma pesquisadora cujo fascínio pelo mundo empírico evita que a teoria atue preguiçosamente como seu substituto e cujo respeito pelos seus interlocutores alimenta o compromisso de apresentar bem a sua experiência, de falar dela com a cautela de quem sabe que é grande o risco de deixá-la escapar pelo recurso a formulações genéricas. Com a etnografia de Luciana aprendemos que se a experiência de indivíduos de classe média no candomblé de Salvador é feita de narrativas biográficas complexas, de interpretações intelectualizadas da mitologia, de encontros inesperados com os orixás, também se tece com os gestos tentativos pelos quais enfrentam as tarefas cotidianas do 
terreiro e os pequenos e repetidos esforços pelos quais tentam vencer sua falta de habilidade prática. Aprendemos que o candomblé está longe de ser uma religião parada no tempo - se refaz na experiência mesma de seus muitos e diversos seguidores e nas diferentes possibilidades que oferece para o desenrolar desta experiência. Ninguém como Luciana Duccini para nos guiar nesses percursos cruzados da religião e de seus adeptos.

Miriam C. M. Rabelo

Prof ${ }^{a}$. dr $r^{a}$. do Departamento de Sociologia e Pesquisadora do Núcleo de Estudos em Corporalidades, Sociabilidades e Ambientes da Universidade Federal da Bahia (ECSAS). 


\section{Introdução}

Em 1999, ao me mudar de São Paulo para a Bahia, tive meus primeiros contatos com terreiros de candomblé. Por coincidência, no mesmo momento comecei a participar de pesquisas de professores a cerca desta religião, tornando-me, em agosto, membro da equipe do projeto "Religião, Tratamento e a Transformação da Experiência: Um Estudo das Práticas Terapêuticas no Candomblé, Espiritismo e Pentecostalismo", coordenado pela prof ${ }^{a}$. dra . Miriam C. M. Rabelo, do departamento de Sociologia da Universidade Federal da Bahia. Dessas primeiras experiências de pesquisa efetiva, incluindo estudos bibliográficos e trabalho de campo, surgiu a questão inicial que orientou a confecção do projeto de pesquisa cujo resultado é este livro. Em suas formulações iniciais, o projeto dizia respeito aos modos específicos pelos quais pessoas de classe média se apropriariam das proposições do candomblé, reinterpretando-as de acordo com seus "interesses ideais”, podendo influenciar a construção de suas identidades.

Desse modo, a proposta de pesquisa se enquadrava numa perspectiva weberiana de interrogação sobre as relações mútuas entre tipos de religiosidade e camadas sociais em processos históricos singulares. Era, no entanto, preciso delimitar a classe em questão. Em se tratando de classe média no Brasil, os estudos disponíveis eram pou- 
cos e, em geral, não colocavam a construção da classe enquanto objeto de estudo como parte do problema, considerando levantamentos estatísticos sobre renda e acesso a bens de consumo como ponto de partida suficiente. Contudo, ao considerar como membros "da classe média” todas as pessoas assim contabilizadas, procede-se a um apagamento de todas as particularidades de sua experiência social que, eu suspeitava, precisavam ser levadas em conta numa exploração de identidades, sejam pessoais ou coletivas. Em meu ponto de vista, era preciso levar em conta tanto a posição dessas pessoas numa situação de mercado (de trabalho e de bens) quanto os diferenciais de prestígio envolvidos em tais posições (WEBER, 1974a) e o acesso diferencial a experiências, atividades, grupos de pessoas, lugares etc. O tratamento dado por Pierre Bourdieu (1999a, 1999b, 2001a, 2003) às distinções de classe incorporadas no habitus e expressas em estilos de vida pareceu-me, então, muito mais adequado para a aproximação ao objeto que me interessava, mantendo a referência à situação econômica e ao status envolvido. Mesmo assim, tratar de questões de prestígio exige a definição de critérios facilmente observáveis que permitam uma aproximação ao posicionamento social dos sujeitos da ação. Dessa forma, a classe média aqui considerada se constituiu a partir de portadores de diplomas universitários que exercem as profissões para as quais se formaram. Os títulos universitários encontram-se relacionados tanto a monopólios de posições no mercado de trabalho (e, portanto, obtenção de renda) quanto a um certo prestígio e a certas disposições incorporadas em longos anos de escolarização que oferecem não apenas conteúdos objetivos do conhecimento, mas, também, esquemas de avaliação e percepção transferíveis a outros campos da prática. (AGIER; CASTRO, 1995; BOURDIEU, 1999b, 2003; GUIMARÃES, 1995)

As reinterpretações religiosas, quando recolocadas no âmbito da ação social, apontam também para as experiências individuais envolvidas. O posicionamento social dos agentes exige que se considere as avaliações e concepções difundidas que, apropriadas pelos sujeitos, 
orientam suas práticas. Assim, foi efetuada uma comparação entre análises que destacam características peculiares das concepções acerca da pessoa correntes na contemporaneidade, em especial entre as camadas "educadas", e os acentos relevantes para as pessoas pesquisadas. Dentre estas, a literatura sociológica tem apontado a importância dos aspectos reflexivos nos processos identitários pessoais e dos percursos individuais para identidades religiosas. Isto indicou mais um critério de seleção das pessoas analisadas: que suas famílias não fossem de candomblé, o que tornaria mais fácil a consideração da autoidentificação como um processo relativo à apropriação de disposições para agir. Evidentemente, após encontrar um primeiro grupo de referência (isto é, delimitado pelas características acima), outras pessoas podiam ser consideradas caso houvesse uma recorrência de indicações pelos primeiros com um ou outro dos referidos critérios. Além disso, nem todas as pessoas aqui consideradas foram formalmente entrevistadas para a pesquisa. Muito das presentes análises se baseia em observações de campo realizadas entre 2000 e 2004, durante três anos no mesmo terreiro, o Ilê Axé Torrundê Ajagun, nas quais, evidentemente, eu não "isolei meus sujeitos de pesquisa" dos demais membros. Na verdade, trabalhando com um conceito de classe social, eu não poderia me furtar a considerar também aqueles de quem minha amostra se distingue e através de quê.

A pesquisa iniciada sob esta perspectiva exigiu que fossem considerados aspectos cada vez mais amplos das relações de tais pessoas com a religião. A questão inicial, então, foi retraduzida nos seguintes termos: "como uma pessoa de classe média passa a ser de candomblé”? Isto dirigiu a investigação para as interações sociais nas quais se desenrolam tanto os processos de identificação quanto a apropriação de disposições. Várias questões surgiram, então, acerca das concepções religiosas sobre a pessoa, a articulação ritual - e, portanto, regulamentada pela tradição de cada terreiro - da identidade, o caráter processual e revisável desta e seu processo fundamentalmente interacional, o que coloca em evidência a presença encarnada 
dos sujeitos nos contextos de ação, onde muitas vezes as distinções de classe ganham espaço concreto para ocorrer. Além disso, pude valer-me do generoso diálogo com os dados de minha orientadora, prof $^{a}$. dr ${ }^{a}$. Miriam Rabelo, que vinha trabalhando com experiências de pessoas de classe popular.

A mútua imbricação dos vários aspectos necessários para que esta análise, ainda que preliminar, não permanecesse unilateral, impediu uma construção textual orientada por "categorias" de elementos ou eventos analisados. Assim, a opção narrativa foi seguir, grosso modo, a progressão cumulativa de perspectivas teóricometodológicas. Dessa forma, o capítulo 1 apresenta um breve panorama da cidade de Salvador, em comparação com alguns indicadores de capitais do Sudeste, destacando uma de suas particularidades históricas: a emergência de uma valorização da "cultura negra" ou afro-brasileira. Para esta edição, os dados utilizados, colhidos e disponibilizados pelo Instituto Brasileiro de Geografia e Estatística (IBGE), foram atualizados para os mais recentes, baseados no Censo 2010 e em pesquisas mensais de 2011. Sobre este panorama genérico, foi feita uma apresentação sucinta do terreiro onde realizei a maior parte do trabalho de campo e alguns aspectos do bairro onde está localizado, no Subúrbio Ferroviário de Salvador. Evidentemente, observações feitas em diversos outros terreiros que frequentei ao longo desses anos, com variados graus de intimidade, também entraram na análise. No entanto, foi no Ilê Axé Torrundê Ajagun, carinhosamente chamado de Torrundê, que pude estabelecer os contatos mais duradouros, que permitiram uma constante retomada de questões, interpretações e dúvidas. A opção de permanecer neste terreiro se deu pelo fato de que seu líder, baba Giberewá, pertence ao grupo aqui pesquisado, assim como cerca de um terço dos demais membros, além, é claro, de questões afetivas que tornaram minha presença lá muito mais agradável.

Após este "instantâneo" inicial do contexto da pesquisa, o capítulo 2 apresenta um levantamento de pontos recorrentes nas tra- 
jetórias religiosas, escolares e profissionais dos entrevistados, com especial destaque para elementos enfatizados por eles. A partir daí, apresento uma discussão do conceito de classe nesta pesquisa em particular, argumentando em favor de uma abordagem que agregue pontos de vista teóricos distintos, mas que favoreçam sua pertinência para a investigação de processos identitários. Em outras palavras, não considero frutífera a utilização de uma construção conceitual que não leve em consideração sua pertinência para as questões colocadas em cada investigação específica. É preciso dizer ainda que, embora os limites desta pesquisa não permitissem identificar um estilo de vida próprio a esta classe média a que me refiro, alguns elementos são comentados, e exponho, ao final do capítulo, de que maneira as pessoas entrevistadas percebem e avaliam as "distinções de classe" em suas interações cotidianas. A procura dos elementos que permitem aos próprios agentes enxergar distinções sociais se mostrou uma das tarefas mais interessantes e frutíferas da investigação.

Visando situar a questão fundamental deste trabalho frente à tradição acadêmica e o candomblé no contexto social analisado, o capítulo 3 tem início com uma retomada das formulações de Max Weber acerca das características típicas ao desenvolvimento das sociedades chamadas "ocidentais modernas". A seguir, apresento uma revisão bibliográfica sobre a presença de indivíduos de camadas mais favorecidas no candomblé, discutindo as maneiras como esta foi, em geral, interpretada - e, normalmente, apenas mencionada de passagem. Retorno, então, às proposições weberianas, comparando seus tipos ideais de religiosidade com as especificidades do candomblé e das experiências religiosas dos adeptos de classe média. Nesse sentido, destaco as diferentes possibilidades de inserção e participação no grupo de culto e as possíveis tensões entre expectativas dos filhos de classe média e as características particulares da religião. Aqui discuto especialmente a fundamentação carismática da autoridade e os conflitos com certas necessidades de racionalização religiosa, apresentando algumas possibilidades de interpretação e negociação. Na verdade, todo 
este procedimento só tem interesse por permitir, ao final, destacar características marcantes das apropriações que as pessoas investigadas fizeram do candomblé, indicando algumas peculiaridades da religião especialmente aptas a atraí-las.

Uma vez apresentado este quadro geral da posição social dos pesquisados, relativa ao contexto em que vivem, e das formas de inserção e interpretação religiosa, volto a atenção para os processos de autoidentificação propriamente ditos. Todo o capítulo 4 concentra-se sobre este tema, discutindo vários aspectos relevantes a serem levados em conta. As identidades pessoais são, então, tratadas com relação a seu caráter processual, aberto e interacional. Discuto a ênfase usual em seus aspectos reflexivos, apontando tanto sua pertinência em certos níveis como sua insuficiência para dar conta dos processos de autoidentificação religiosa. Neste ponto, foi interessante apontar para as relações entre narrativas, experiências e identidades. Retomo a discussão acerca da construção ritual da identidade religiosa, enfatizando a necessidade de tratar das interações concretas em que se desenrolam e, portanto, da presença encarnada dos sujeitos na comunidade de culto. Algumas análises propostas por diferentes autores que tocam na questão da identidade no candomblé são comentadas principalmente pelo fato de convergirem em apontar a importância da manutenção de dualidades na perspectiva teórica, evitando que estas sejam transformadas em dicotomias.

O capítulo 4 segue uma estrutura um pouco distinta dos demais, pois sua primeira parte é baseada num trecho de entrevista especialmente elucidativo para a análise da identidade pessoal e, subjacente a toda a discussão, há uma preocupação em destacar o modo como os adeptos compreendem suas relações com os orixás. Aqui encontramos um paralelismo entre suas formulações e a perspectiva teórico-metodológica: também eles indicam a importância das interações em que se envolvem para suas identidades e uma consideração cuidadosa de quem são os agentes nessas relações. Os próprios orixás foram, dessa maneira, tomados sob pontos de vista complementares: 
como conhecimentos incorporados no âmbito reflexivo dos processos identitários; como agentes com os quais se interage e negocia; e enfim, como formas de conhecimentos emergentes a partir das experiências dos indivíduos nestas interações. Considerei rapidamente algumas proposições acerca da relação entre narrativas, experiência e identidade, apenas com o intuito de clarificar as relações entre o nível reflexivo e o experiencial, indicando a relevância dos aspectos pré-reflexivos para a compreensão dos processos identitários. Por fim, o capítulo introduz reflexões iniciais sobre a corporalidade e seu caráter produtivo na autoidentificação.

O capítulo 5 consiste em aprofundar este ponto tanto no debate teórico quanto na relação com a pesquisa etnográfica. De início os conceitos de habitus e embodiment são retomados e postos em diálogo. A proposta é que ambos podem ser operacionalizados como um par complementar que permite focalizar tanto a constituição ativa do mundo humano pelos sujeitos em sua ação quanto as especificidades de seu posicionamento social enquanto sujeitos históricos. Dessa forma, momentos em campo foram retomados e analisados à luz das disposições incorporadas pelos envolvidos, evidenciando como a relação com o mundo e os outros solicita o engajamento dos sujeitos, reelaborando suas próprias "fronteiras". Alguns pontos que já haviam sido expostos nos capítulos anteriores ressurgem, então, sob outros ângulos. Neste último capítulo a questão inicial que orientou todo o trabalho é retomada em um sentido radical: passar a ser uma pessoa de candomblé é uma forma de estar no mundo - o que envolve tanto o existir individual quanto o que conta como mundo. Neste sentido proponho que o processo de autoidentificação de pessoas de classe média nesta religião se dá no jogo entre as disposições já adquiridas e aquelas exigidas no contexto particular, o que evidencia a mobilidade dos limites do sujeito e a dinâmica complexa entre sua determinação social e sua flexibilidade existencial.

Considerando que a relação com o candomblé como algo "próprio" - tanto no sentido de apropriado quanto de propriedade - 
é uma afirmação sobre a existência, este trabalho se encerra com a retomada de alguns elementos distintivos que esta afirmação assume para as pessoas diretamente pesquisadas. De acordo com as análises que precederam esta última seção, os orixás apresentam certas características peculiares: são simultaneamente o mais genérico e o mais individual. O argumento final é que as próprias divindades, ao encarnarem neste mundo, através dos corpos de seus adeptos, são constituídas no mesmo movimento exploratório que nos dá este mundo. Assim, compartilham do caráter dos sujeitos constituídos em sua exploração ativa o que sugere que orixás, erês, caboclos, exus e eguns podem ser considerados como agentes também constituintes e constituídos no mundo com outros. Tal afirmativa, porém, aproxima-se perigosamente do âmbito do discurso propriamente religioso, sobre o qual não tenho nem o direito nem a intenção de me manifestar, de forma que tudo o que posso fazer é apresentar mais uma questão: qual a relação do conhecimento objetivado, "científico", com aquele conhecimento primordial que eu afirmo ser emergente da experiência? Evidentemente, não tenho condições de responder a esta indagação e gostaria apenas de deixá-la explícita para, mais uma vez, indicar que nunca foi minha pretensão esgotar o objeto tratado através do diálogo entre perspectivas teóricas distintas - uma vez que não creio nesta possibilidade.

Propor que as perspectivas analíticas sejam aprofundadas numa referência mútua, complementando-se umas às outras de modo a iluminar cada vez mais aspectos do mesmo objeto comporta um grande risco: por nunca esgotá-lo, faz surgir sempre novas questões. Dessa forma, o momento final da discussão que apresento aqui remete para mais um âmbito de construção do objeto, aquele que diz respeito à relação entre a autoidentificação com o candomblé por parte de pessoas de classe média e a ancestralidade. A partir daqui, é possível desdobrar toda uma série de novas questões que merecem um projeto de pesquisa por direito próprio, mas que não poderia ser pressuposta ou dada de antemão sob a forma de concepções reificadas sobre pessoas e 
ancestrais. Para que estas questões pudessem emergir, era necessária toda a construção do objeto do qual apresento a seguir algumas possíveis "visadas".

Ao reler o trabalho com vistas à publicação, optei por fazer algumas atualizações que, contudo, não alteraram os argumentos centrais da tese, nem sua estrutura, embora eu tenha subdividido o primeiro capítulo original em dois. Esta decisão teve motivos estéticos, para facilitar a leitura, e não teóricos, de modo que não a considero como uma alteração de conteúdo significativa. De forma semelhante, foram eliminados alguns comentários e explicações repetitivas e acrescentados mais momentos extraídos do trabalho de campo. Infelizmente, nestes anos que se passaram entre a defesa da tese e a publicação deste livro, embora alguns membros do terreiro tenham tido acesso ao texto integral da mesma, obtive poucos comentários a cerca de minhas interpretações e, em geral, provenientes de adeptos que cursavam alguma pós-graduação. Muitas pessoas me fizeram relatar, em alguns momentos, partes de minhas conclusões, com as quais pareciam satisfeitas, mas não pude obter um retorno sistemático sobre minha maneira de apresentar uma parte importante de suas vidas. Desse modo, ficou a lacuna da resposta dos entrevistados sobre minhas interpretações acerca de suas experiências.

Por fim, gostaria de reiterar que todas as perspectivas nos dão apenas aspectos e não a totalidade da vida. Assim, desde já manifesto que tenho consciência do possível desagrado que este trabalho pode provocar naqueles que gentil e graciosamente me cederam seu tempo e suas histórias. Peço a eles que me desculpem pela desconstrução de seus relatos e ideias, mas que tenham em mente que não me proponho a apresentá-los como realmente são e sim realçar os pontos que se relacionam com o objeto aqui construído. Não se trata de um mundo textual irreal ou fictício, mas de um retrato necessariamente parcial que desloca e não dá conta do fluxo ambíguo e inconstante da vida de cada um de nós. Afinal, o mundo em que vivemos de fato, 
que não se reduz às objetificações abstratas que dele podemos fazer, é o mundo que exploramos em nossa condição de sujeitos da cultura:

O mundo fenomenológico não é puro ser, mas o sentido que é revelado onde as trilhas de minhas várias experiências se encontram e também onde ocorre a intersecção das minhas próprias e das dos outros, onde elas se engajam umas nas outras como direcionadores. (MERLEAU-PONTY, 1962) 


\section{Uma classe média em Salvador, um terreiro no subúrbio}

\section{SALVADOR: CAPITAL DA BAHIA, METRÓPOLE DO NORDESTE}

Salvador, com suas praias e construções da época colonial, é a mais bela cidade do Atlântico Sul, segundo a página oficial da prefeitura municipal. Para quem vem de São Paulo, no entanto, Salvador apresenta uma fisionomia curiosa: próximo aos prédios residenciais de alto padrão aglomeram-se incontáveis construções sem acabamento, sem projeto arquitetônico, espremidas umas contra as outras, nas quais são erguidos dois, três, até quatro andares, em vielas e escadas por onde mal se passa uma geladeira. É costume dizer que “o sonho do baiano é bater laje", ou seja, construir mais um andar da própria casa, ou até mesmo outra residência independente. Aqui o "padrão periferia" é encontrado nas áreas centrais da cidade e não somente nos subúrbios distantes. ${ }^{1}$ Contudo, a periferia, propriamente dita, não é tão "feia": Paripe, Plataforma e outros bairros do Subúrbio Ferroviário

Isto se refere a um período anterior ao governo Lula. Após seus dois mandatos, esse padrão de construção mudou visivelmente, incorporando acabamento e pintura externa a muitas moradias em Salvador, embora ainda se destaquem claramente das construções de alto padrão. 
não são totalmente marrons nos tons dos tijolos e da terra batida. Há muito mais verde, seja nos terrenos desocupados e cobertos de mato, seja nos quintais, jardins, canteiros e quaisquer outros pequenos espaços tomados por árvores e plantas de diversos portes, seja pela vegetação característica da região que ainda estabelece limites à grande cidade, onde a Baía de Todos os Santos não o faz. Existe ainda o parque São Bartolomeu, reserva florestal situada no bairro de Plataforma, que, embora não seja amplamente frequentado devido à violência, ainda fornece uma imensa área verde com riachos e cachoeiras.

À primeira vista, a "periferia no centro" - antigas invasões hoje regularizadas, como o Alto das Pombas, na Federação, se embrenhando pelas encostas e circundando áreas comerciais e residenciais muito mais valorizadas - pode dar a impressão de uma grande proximidade entre camadas sociais distintas, assim como as massas que se aglomeram no Carnaval e nas festas de largo. ${ }^{2}$ No entanto, a proximidade física parece não diminuir a distância social e Salvador é muitas vezes referida pela pobreza e pela grande desigualdade que divide sua população, na maioria negra. De fato, a capital baiana apresenta altos índices de precariedade e informalização do trabalho (CASTRO, 1998; CASTRO; BARRETO, 1998, GORDILHO, 2000), além da concentração de renda costumeira no país.

De toda forma, Salvador é hoje uma das grandes cidades do país, com mais de 2,6 milhões de habitantes ${ }^{3}$ no município em 2010 e 3,7 milhões na região metropolitana em 2009 (IBGE, 2010). Destes residentes, 1.925 mil eram economicamente ativos, em novembro

Como são chamadas as festas que acontecem nas ruas, como a festa de lemanjá, no Rio Vermelho, a procissão da Conceição da Praia e a Lavagem do Bonfim. Em geral, tais eventos misturam motivos religiosos à festa profana, com barracas de comida, bebida e jogos, além de muita música e paquera, tudo imerso no sincretismo com o candomblé.

3 Os dados utilizados nesta seção foram atualizados sempre que possível, pois embora tenham ocorrido muitas mudanças na economia brasileira entre a redação da tese e a revisão para o livro, veremos que o perfil geral das camadas de renda e escolaridade nas capitais consideradas não se alterou significativamente. (IBGE, @ 2014 ) 
de $2010,{ }^{4}$ o que representava $57,4 \%$ da população em idade ativa, isto é, com 10 anos de idade ou mais. Desta última, 52,1\% encontrava-se ocupada no referido mês, revelando um pequeno crescimento com relação aos anos de 2004 (50,2\%) e 2005 (49,9\%) que, contudo, apresentou tendência de queda em novembro de 2011, com 50,8\% da população em idade ativa (IBGE, 2011), o que permite considerar o nível de ocupação na cidade de Salvador como relativamente estável na última década. Isto, porém, só apresenta alguma relevância para o enfoque dado neste estudo, quando considerado o conjunto das relações de ocupação, renda e escolaridade da população da cidade, seu desenvolvimento histórico e configuração econômica entre as demais capitais brasileiras, possibilitando visualizar o cenário no qual destacaremos o estilo de vida da classe média aqui considerada.

Figura 1 - Bairros da Ondina e do Calabar

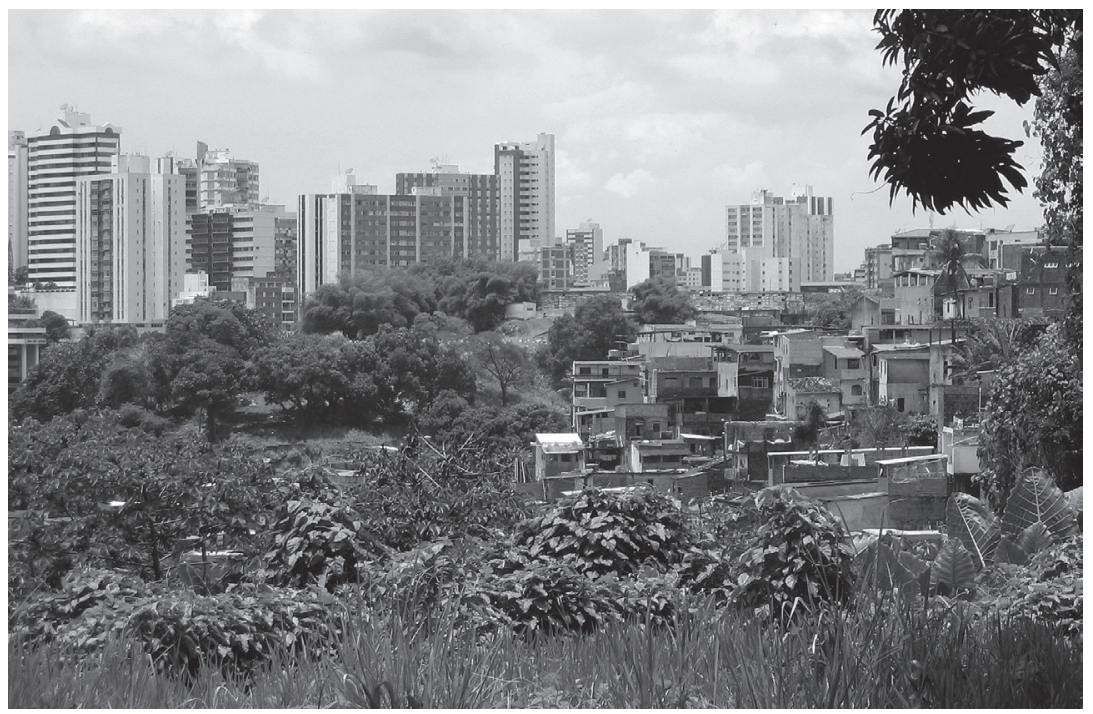

Fotógrafo: Elena Calvo-Gonzalez.

Dessa forma, interessa ressaltar que, entre 2004 e 2010, a proporção da população ocupada com carteira assinada no setor privado

4 A variedade das fontes consultadas deve-se ao fato de que, muitas vezes, os dados disponíveis não se referem às mesmas unidades territoriais ou ao mesmo período. 
subiu de $33,8 \%$ para $42,3 \%$, ao passo que a ocupada no setor privado sem carteira caiu de $14 \%$ para $11,9 \%$. Já a população ocupada no serviço público (funcionários e militares) ficou entre 7,5\% e 7,9\%, respectivamente, e como empregadores entre $4,2 \%$ e $3,7 \%$. A taxa da população ocupada por conta própria teve queda de $26 \%$, em novembro de 2004, para 20,7\% em 2010. Da população ocupada em novembro de 2010, 14,6\% tinha entre quatro e sete anos de estudo, $14,1 \%$ entre oito e 10 anos e $66,4 \% 11$ anos ou mais. Embora estes dados indiquem que há maior probabilidade de se conseguir uma ocupação quanto maior for a escolaridade, não significam que esta resulte, necessariamente, em melhor posição ocupacional, pois entre a população desocupada (em idade ativa) da capital na mesma época, encontrava-se 60,4\% com mais de 11 anos de estudo (bastante acima dos $55,5 \%$ encontrados nas seis regiões metropolitanas analisadas) e 20,8\% entre oito e 10 anos. É preciso considerar ainda que Salvador apresentava uma taxa de analfabetismo entre pessoas de 15 anos ou mais de $4 \%$, naquele ano, bem abaixo da taxa nacional $(9,6 \%)$ e da encontrada em Recife $(7,1 \%)$, porém acima de capitais do Sudeste como Belo Horizonte (2,9\%) ou São Paulo (3,2\%) (IBGE, 2011). Contudo, no que diz respeito aos adolescentes entre 15 e 17 anos frequentando o nível escolar adequado, a taxa no Nordeste continuava abaixo daquela encontrada no Sudeste no ano de 2009, respectivamente $39,2 \%$ e $42,1 \%$, embora tenha havido ligeira melhora no país como um todo (IBGE, 2010, p. 46).

Discrepâncias também podiam ser verificadas no acesso à renda das grandes regiões e suas capitais. No ano de 2010, o rendimento médio total nominal efetivamente recebido pelas pessoas ocupadas com 10 anos de idade ou mais foi de $\mathrm{R} \$ 1.371,00$. Contudo, quando comparado ao rendimento mediano, ou seja, o número que divide a população investigada exatamente ao meio, vemos que o valor recebido foi de R\$ 605,00, o que significa que uma parcela minoritária da população, praticamente, duplica o valor da renda média, enquanto a maioria, na verdade, recebe bem menos do que o acima mencionado. 
Em São Paulo, esses valores eram de R $\$ 1.989,50$ e R \$ 935,00, respectivamente, e em Belo Horizonte, de R \$1.942,00 e R\$ 885,00. Embora esta discrepância entre os valores médios e medianos esteja presente em todas estas capitais, vemos que tanto o rendimento médio quanto o mediano eram relativamente baixos em Salvador. Não apresento estes números com o intuito de introduzir uma análise quantitativa da classe média em Salvador - o que, diga-se de passagem, é extremamente difícil, devido à ausência de estudos semelhantes no Brasil, como aponta Figuereido (2003, f. 46) - , mas apenas fornecer um panorama geral do que significa ser de "classe média" numa metrópole nordestina, em comparação com alguns elementos de outras grandes cidades do país. Evidentemente, tudo isto só faz sentido quando consideramos as características específicas da formação da cidade de Salvador e sua região metropolitana.

Figura 2 - Av. Vasco da Gama, vista da área popular em direção à de classe média

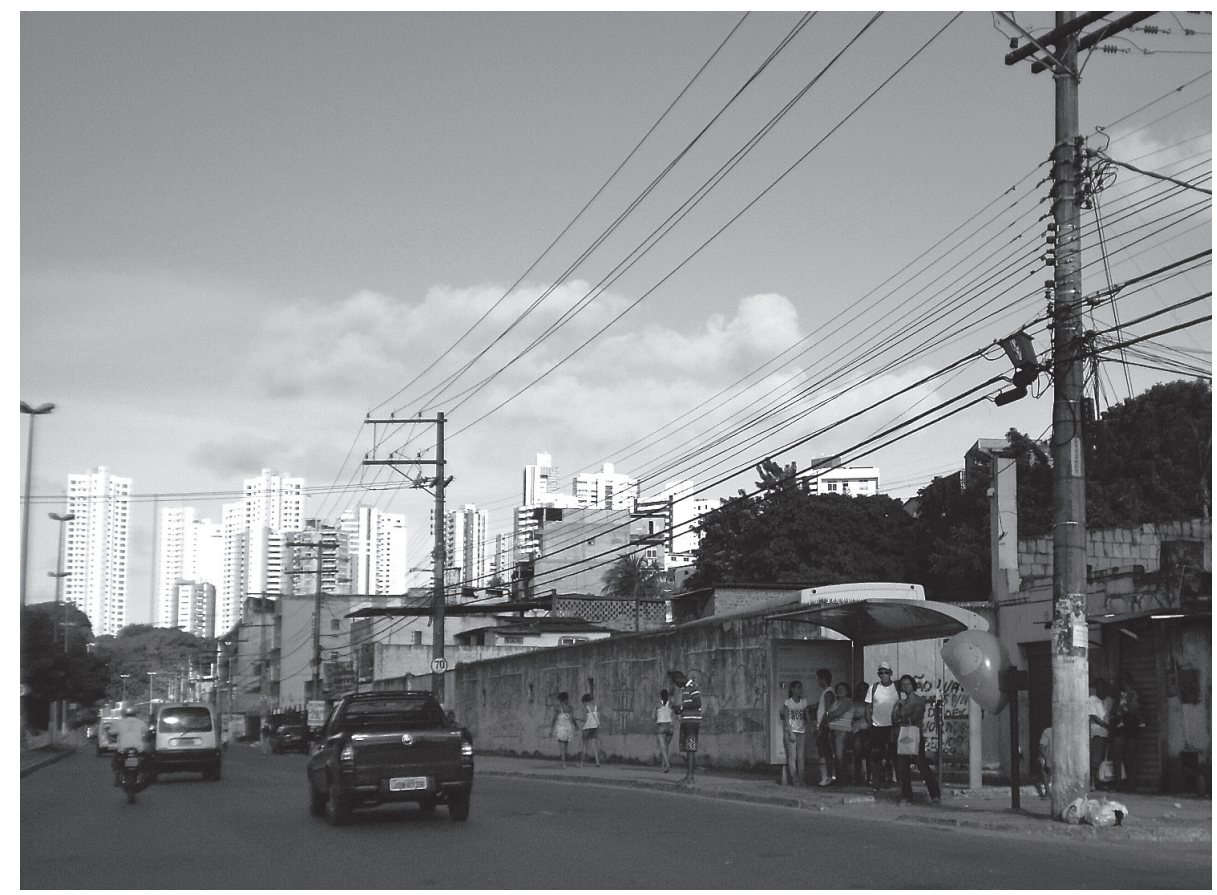

Fotógrafo: Luciana Duccini. 


\section{AS POLÍTICAS PÚBLICAS DE INDUSTRIALIZAÇÃO E O EMPREGO}

Segundo Castro e Barreto (1998, p. 145), em meados do século XIX houve um florescimento da economia industrial na Bahia, seguido por um período de estagnação na primeira metade do século XX. A partir dos anos 1950, porém, o crescimento industrial foi retomado com investimentos estatais na indústria de petróleo. Nas décadas de 1960 e 1970 as políticas públicas de desconcentração industrial, através de incentivos fiscais e financeiros, impulsionaram o crescimento econômico da Região Metropolitana de Salvador (RMS), encontrando um mercado de trabalho urbano já consolidado pelos períodos de desenvolvimento anteriores. Até mesmo a década de 1980 - muitas vezes chamada de "década perdida", devido à recessão no país - ainda manteve as consequências positivas das políticas de industrialização e o estado da Bahia continuou crescendo até o início dos anos 1990. Entretanto, apesar de todo esse crescimento ser calcado na industrialização, este processo não foi capaz de alterar os altos níveis de informalização e precarização do trabalho:

Sabemos, ademais, que a ampliação do processo de precarização do trabalho se deu na RMS a partir do final dos anos 60, paradoxalmente, no mesmo momento em que se intensificava o crescimento econômico local com base na indústria de bens intermediários. Este importante surto de industrialização gerou uma estrutura ocupacional moderna, em torno do Pólo Petroquímico de Camaçari, elevou a arrecadação pública, incrementou a massa salarial em Salvador e RMS, diversificou o comércio, gerou pequenos negócios na área de serviços direcionados ao Pólo. Entretanto, pela ausência de indústrias de terceira geração, teve um efeito relativamente restrito sobre o emprego; [...] Nessas condições, a grande massa urbana continuou a sobreviver em situação de precarização, mesmo num período de acelerado crescimento econômico local. (CASTRO; BARRETO, 1998, p. 162)

Na verdade, o impacto do desenvolvimento industrial na RMS foi muito além dos empregos diretamente gerados que, no final da 
década de 1980, representavam apenas $12 \%$ do emprego total, enquanto serviços ${ }^{5}$ e comércio detinham, respectivamente, 48,8\% e $18,9 \%$ dos postos ao passo que, em novembro de 2011, serviços e comércio representavam $52,4 \%$ dos postos ocupados, a indústria de extração, transformação e produção 10,9\% e a da construção 9,2\%.6 De acordo com Castro e Barreto (1998), cerca de 80\% do emprego na RMS ao final dos anos 1980 tinha alguma relação com a industrialização. Isto, porém, não significou a reversão de relações de trabalho precárias, uma vez que Salvador manteve altas taxas de desemprego oculto, em comparação com São Paulo, por exemplo, até o ano 2005, o que segundo Gozanga (2006, p. 445) indica a deterioração do mercado de trabalho.

Ainda assim, não apenas os números, em postos de trabalho e renda, sofreram grande influência das políticas estatais de desenvolvimento para a região. O "emprego no Pólo" e nas empresas similares passou a conformar carreiras profissionais e expectativas para uma larga parcela dos trabalhadores. A profissão de nível técnico, especializada, que oferecia salários muitas vezes semelhantes aos de profissionais de nível superior, além de garantias trabalhistas, passou a fazer parte do horizonte, e dos sonhos, de homens e mulheres de classe baixa (mas não tão pobres que não conseguissem perseguir uma escolarização mínima, nem sempre alcançando o nível médio) e de classe média baixa, exercendo um amplo impacto tanto na configuração de suas identidades, como mostram Guimarães, Agier e Castro (1995), quanto na reconfiguração de distinções de classe. Segundo Castro e Guimarães (1995), com a estabilização de camadas operárias fabris, seus padrões de consumo e distinções de status puderam ser redefinidos, mas ao mesmo tempo, as camadas médias também redefiniram os seus próprios padrões. Nesse movimento, os autores destacam como relevante para a compreensão de tais distinções os

Exclusive serviços domésticos, cuja taxa era de 9,1\%.

6 Pesquisa Mensal de Emprego: Salvador (IBGE). Novamente, excluindo-se serviços domésticos, com taxa de $8,3 \%$ dos postos de trabalho. 
eixos trabalho (e sua organização), família, capital cultural, distribuição de poder na fábrica e fora dela (AGIER; GUIMARÃES, 1995), apoiando-se na ideia de que a situação de um indivíduo não pode ser reduzida à sua posição na esfera econômica e, muito menos, pode-se inferir a partir daí a formação de uma identidade de classe.

Com as transformações na esfera do trabalho mencionadas acima, ganhou importância a noção de "profissão" (em oposição a “ofício") como uma “[...] atividade permanente de caráter técnico e mental, dotada de uma carreira, ou seja, de uma gradação de funções e cargos que só podem ser exercidos pelos titulares de um diploma.” (AGIER; GUIMARÃES, 1995, p. 42, grifo do autor) As profissões de caráter técnico foram, então, associadas a oposições entre moderno e antigo, útil e inútil, produtivo e improdutivo, os últimos termos sendo correlacionados à tradição bacharelesca das universidades. (AGIER; GUIMARÃES, 1995)

Mesmo assim, esta reconfiguração das representações e das posições objetivas no trabalho não significou uma real perda de prestígio das profissões de nível universitário. Estas continuaram a deter não apenas maior valor social, como também o monopólio das funções "menos subordinadas" na fábrica, aquelas que permitiam uma adequação do tempo do trabalho ao das atividades familiares e sociais, quebrado pelo trabalho em regime de turno. Muito mais do que um conhecimento tecnicamente superior, tais funções exigiam o domínio de condições internas e externas ao processo de produção em si mesmo (AGIER; GUIMARÃES, 1995) isto é, um conhecimento muito mais amplo que é socialmente valorizado como superior. Era, e ainda é, o diploma universitário o único meio de acesso a esta "outra” esfera do trabalho e as carreiras de nível médio encontravam aí um bloqueio intransponível na ausência da escolarização continuada.

Guimarães (1995) analisa exatamente a situação de um operário que, proveniente da "pequena classe média" do interior, optou por ingressar na indústria petroquímica como profissional de nível técnico ao invés de investir numa carreira universitária, como fizeram seus 
três irmãos. A princípio, frente às dificuldades financeiras e familiares do momento e às possibilidades econômicas de tal emprego, a escolha parecia compensadora. No entanto, como mostra o autor, ao longo do tempo essas vantagens foram superadas por aquelas obtidas pelos irmãos com carreiras universitárias, e este indivíduo ressentia-se das relações de trabalho vividas, sobretudo, por suas ausências do convívio familiar.

Em suma, Guimarães, Agier e Castro (1995) revelam que as percepções do trabalho e da identidade do trabalhador não são delimitadas apenas pelo rendimento auferido e pelo consumo que proporciona, mas também pelo tipo de saber mais, ou menos, socialmente valorizado que requer. Estes conhecimentos, geralmente, estão correlacionados com o monopólio de certas funções e cargos (expresso em títulos e diplomas), correspondentes a determinados usos do tempo (por sua vez também valorados) e pela relação com as possibilidades e expectativas construídas no ambiente familiar. Até mesmo a participação em movimentos reivindicatórios deve ser analisada, segundo os autores, em relação com esses outros elementos e não apenas face à posição do sujeito no processo de produção.

Dessa forma, não podemos negar que a escolarização de nível superior se faz acompanhar, muitas vezes, de rendimentos mais elevados, como mostra Almeida (2006). Fazendo uma comparação entre os custos médios de uma graduação e os rendimentos médios por idade com e sem o curso superior, Almeida concluiu que a posse de um diploma universitário pode aumentar entre 50 e 100\% os rendimentos líquidos ao longo da vida de uma pessoa. Mais precisamente, no ano de 2006, na cidade de Salvador, o portador de um diploma de universidade pública viria a receber, ao final de sua vida de trabalho R\$ 623.477,91 a mais do que uma pessoa com apenas o nível médio. (ALMEIDA, 2006) Para o caso de um diploma de faculdade particular a diferença caía para $\mathrm{R} \$ 587.477,91$. Isto quer dizer que, embora não possamos limitar o estilo de vida da classe média ao seu diferencial de renda, nem inferi-lo diretamente da posse de um diploma de cur- 
so superior, podemos dizer que a afirmação do senso comum de que renda e padrão de consumo estão ligados à escolarização prolongada, de fato, têm grandes probabilidades de se verificar. ${ }^{7}$

Figura 3 - Av. Manoel Dias da Silva no bairro da Pituba

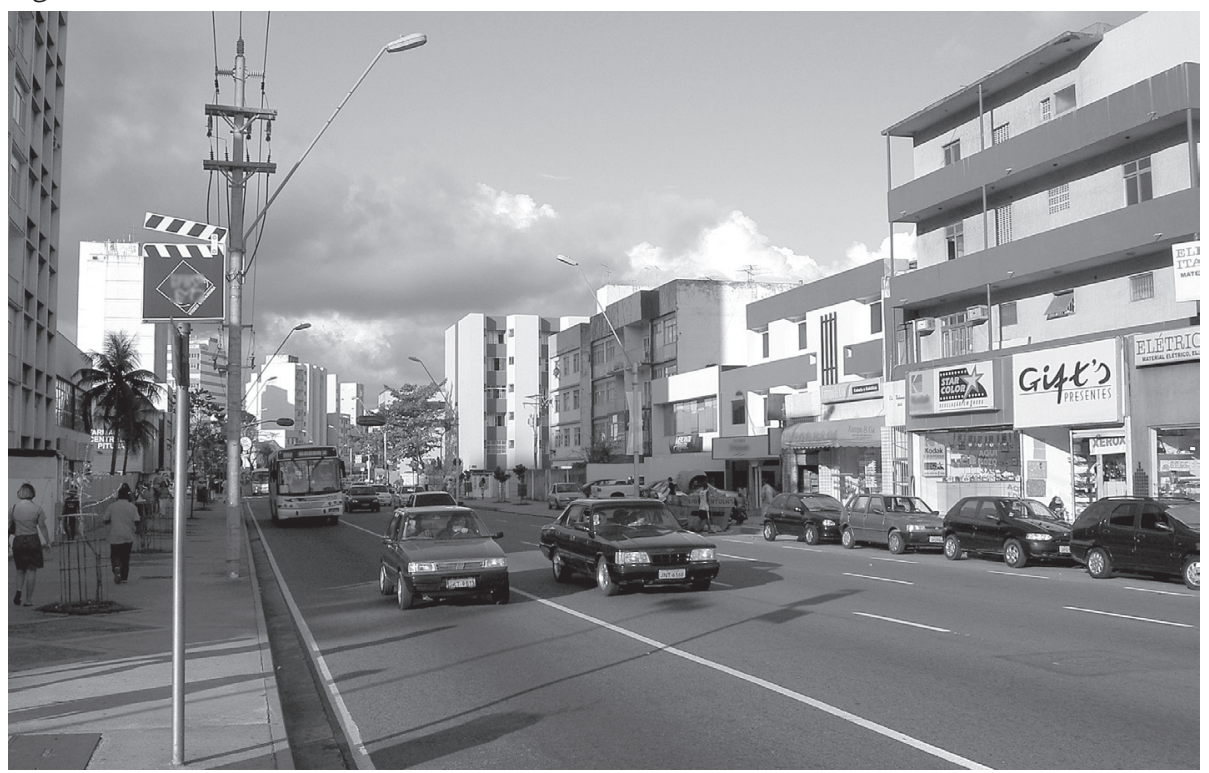

Fotógrafo: John Gledhill.

Em resumo, podemos dizer que Salvador passou por um período de acelerado desenvolvimento industrial (entre os anos 1950 e 1970) que, apesar de figurar no horizonte de possibilidades de trabalho e ascensão social de ampla parcela da população, não foi capaz de reduzir as disparidades entre diferentes camadas sociais, nem de diminuir os altos índices de desemprego e pobreza, tampouco de absorver um efetivo realmente grande de trabalhadores a ponto de criar uma camada operária "média” numericamente expressiva. Além disso, distinções de status baseadas na formação universitária e exercício

\footnotetext{
Embora o trabalho de Almeida apresente médias estatísticas e tenha um caráter probabilístico, não apresentando uma relação de determinação entre escolaridade e renda, trata-se de um exercício interessante e realizado a partir da ponderação de diversas variáveis, como média de tempo de trabalho no conjunto das ocupações em Salvador, média de anos de estudo para a graduação, custos diretos e indiretos dos cursos etc.
} 
de profissões correlatas permaneceram operantes, mesmo que não resultassem em renda muito mais elevada. Em concordância com as propostas destes autores, as pessoas por mim investigadas avaliavam positivamente o domínio de certos “conhecimentos” e certas modalidades de consumo. Tal qual a classe média paulistana pesquisada por O’Dougherty (1998), , a classe média soteropolitana que vai ao candomblé também vê na "diferenciação cultural" aquilo que a distingue de estratos mais baixos.

Figura 4 - Residências populares na av. Vasco da Gama

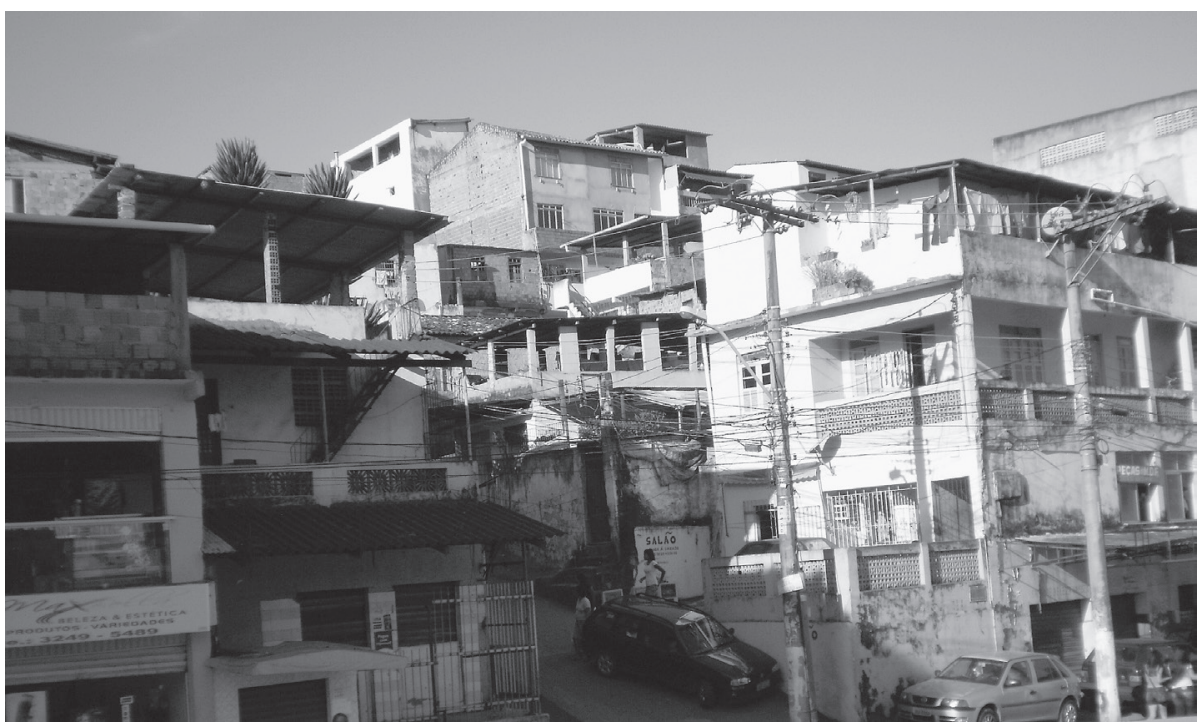

Fotógrafo: Luciana Duccini.

\section{A VELHA "ROMA NEGRA"}

No entanto, isso ainda não é tudo. É preciso levar em consideração que Salvador é tida como a "grande metrópole negra" do Brasil. Referências à negritude - e aos seus corolários "culturais", tais como a capoeira, a música e o candomblé - estão por toda à parte.

8 Todavia, não defino a "classe média" somente em termos de consumo, mas também em termos de profissão, o que será discutido na seção final deste capítulo. 
São famosos os afoxés, como Filhos de Gandhi e blocos afros, como Ilê Aiyê, presentes não apenas no Carnaval, mas em muitos outros eventos: nas festas religiosas (e também "profanas") da Lavagem do Bonfim, de São Lázaro, São Roque e Iemanjá; nos shows, gratuitos ou não, em lugares amplos da cidade, muitas vezes patrocinados pela prefeitura ou outro órgão público. É possível comprar berimbaus, pandeiros ou calças de capoeira com relativa facilidade, seja como "souvenir", seja para uso de fato. Exibições da luta são mais restritas às áreas turísticas, embora seja bastante fácil encontrar uma roda ou uma escola de capoeira por toda a região central, nos bairros de classe média e mesmo nos colégios frequentados por suas crianças. Sem contar a variedade de penteados para cabelos crespos que se vê nas ruas, bem como estampas e tecidos "afro".

Figura 5 - Orixás do Dique do Tororó

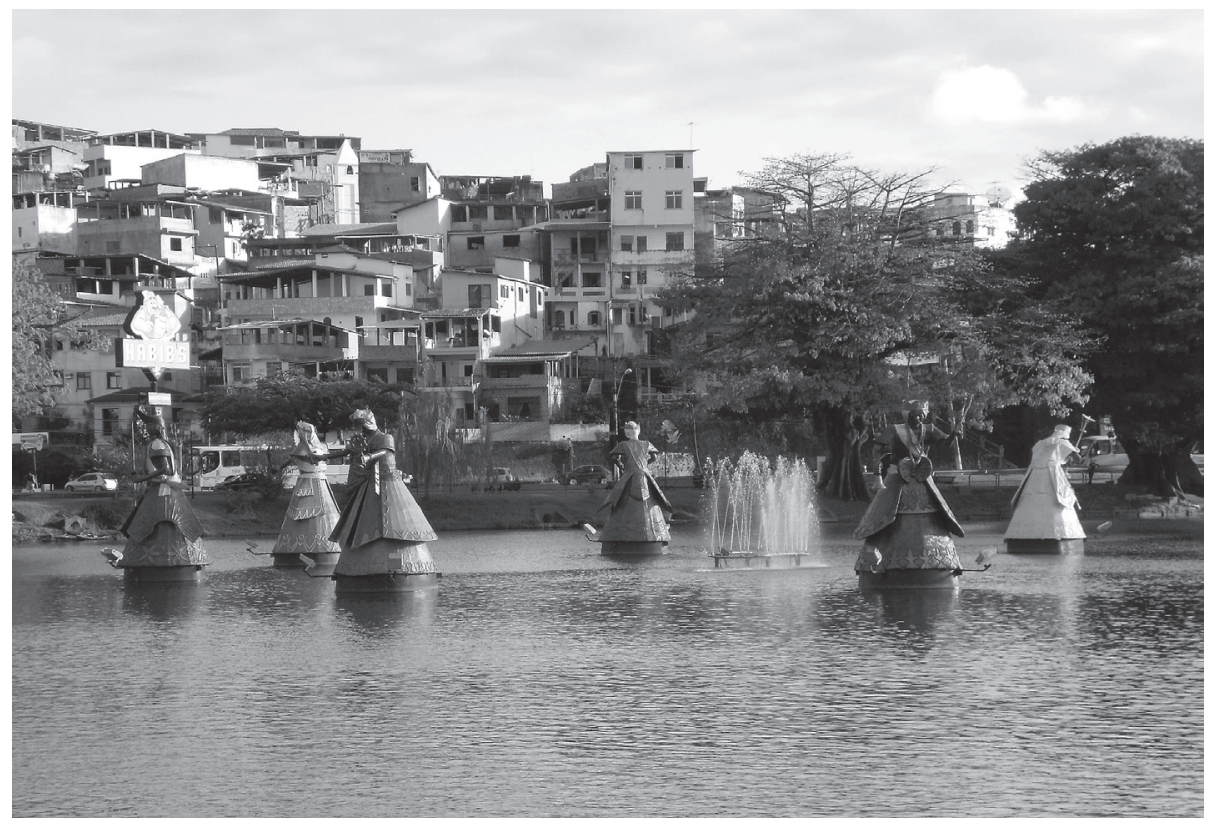

Fotógrafo: Luciana Duccini.

Estátuas de Orixás enfeitam o lago do Dique do Tororó, uma grande área pública transformada em área de lazer pela prefeitura 
municipal, com direito a painel explicativo sobre quem é cada um. Esculturas mais estilizadas, de artistas plásticos famosos como Caribé ou Bel Borba, podem ser encontradas no Rio Vermelho, bairro boêmio onde se pode comer acarajé e tomar cerveja em mesinhas de plástico dispostas pelos bares, antes de ir dançar ou assistir a um show de rock numa das pequenas casas noturnas da região. A central dos Correios, na Pituba, apresenta também três obras representando Iemanjá, Exu e Oxalá, este último sobre uma grande base de concreto redonda onde se vê os outros orixás em relevo. As baianas de acarajé, com suas saias enormes, batas de renda e torços, podem ser encontradas em cada esquina. De maneira mais discreta, são vários os edifícios que trazem nomes como Oxalufã (no Centro), Nanã (na Barra), Logunedé (em Ondina) e até mesmo baba Elemajó (no elegante bairro da Graça). Isso sem contar com o Vale do Ogunjá, avenida cujo nome oficial ninguém sabe, pois até a placa de trânsito traz o nome do orixá. Alguns dos terreiros mais conhecidos são de fácil acesso, próximos ao Centro, como a Casa Branca e a Casa de Oxumaré, na avenida Vasco da Gama, e o Gantois, na Federação. No caso dos turistas, é possível agendar, através da própria Bahiatursa, uma visita com guia a um terreiro, preferencialmente, quando há cerimônias públicas.

Na verdade, essa "publicidade" de elementos da "cultura afro", especialmente do candomblé, faz parte de um processo que se desenrola desde a década de 1960 e que pode ser interpretado como uma busca pela "autenticidade" relacionada ao movimento muito mais amplo, de caráter internacional, da contracultura. (PRANDI, 1999, p. 102) No caso do Brasil, essa autenticidade veio a valorizar aspectos que já eram colocados em evidência desde o século XIX, com a grande questão da "identidade nacional mestiça". ${ }^{9}$

Ver Schwarcz (1995) para uma discussão sobre a problemática racial na preocupação em conformar uma identidade "verdadeiramente brasileira" e positiva; ver também Birman (1997) para uma crítica das relações entre este interesse difuso e as religiões afro-brasileiras na academia. 
Como afirma Sansone, (2000, p. 93) “[...] a desestigmatização de várias expressões culturais tidas como típicas dos negros na Bahia urbana, o que lhes permitiu tornarem-se parte da imagem pública do Estado da Bahia [...]" teve lugar num processo de intercâmbio de objetos e ideias entre grupos e locais (entre estados brasileiros e destes com outros países, sobretudo Estados Unidos e alguns países africanos), que culminou com uma ênfase no consumo como marca de identidade. Assim, em Salvador, há sempre a possibilidade de se optar por consumir bens e produtos "autênticos" (de referência africana), "modernos" (SANSONE, 2000, p. 98) ou simplesmente o que está nas revistas de moda (que incluem de roupas e livros a como educar os filhos). Num resumo muito breve, o que nos mostra o autor é que o consumo também é uma arena de constituição de marcas de identidade (e nesse caso visíveis desde a primeira impressão) e que, mesmo num contexto de "globalização" e de produção de massa, as apropriações (e não poderíamos dizer "opções”, num sentido bastante amplo?) que se faz dos objetos de consumo sofrem constrangimentos históricos locais. Assim como qualquer metrópole, Salvador comporta espaços de criação de estilos de vida diversificados, porém, com um acento especial naquilo que remete à África, como típico da cidade.

Se, como foi mencionado acima, os setores de serviços, comércio e indústria concentram a maior parte dos empregos em Salvador, podemos esperar que uma pessoa de "classe média" seja dona de uma microempresa de serviços especializados (imobiliárias, por exemplo) ou de uma microindústria (especialmente manipulação de alimentos ou confecções), profissional liberal (principalmente médico ou advogado) ou, com menos frequência, funcionário de nível superior do poder público ou de uma grande empresa. Essa pessoa também tem muito mais chances de morar: em Brotas, Rio Vermelho, Amaralina, Nazaré ou Barris, bairros de ocupação mais antiga, próximos ao Centro; num dos novos bairros entre a Orla e a avenida Paralela (via expressa que liga a região do Iguatemi à Lauro de Freitas, município onde se localiza o Aeroporto e muitas das "boas praias” mais próximas), como o Imbuí; em outros bairros mais recentes da Orla; na 
Ondina, Barra, Graça, Vitória, bairros antigos de classe média e alta, comercialmente muito valorizados, ou ainda na Pituba e Itaigara, estes últimos mais homogêneos quanto aos padrões de construção.

Há também grandes chances de que esta pessoa escolha frequentar preferencialmente as cinco salas de cinema do Circuito Sala de Arte ou as 24 do Multiplex e UCI; sair à noite na Barra ou Rio Vermelho, ou preferir o Aeroclube (um shopping de lazer que concentra restaurantes, lanchonetes, lojas de roupas e 10 salas do UCI), ${ }^{10}$ os grandes bares da Pituba e as grandes casas de shows da orla (onde, em geral, se apresentam as bandas de pagode ou forró do momento); ir à praia em Stella Maris e Flamengo (ao norte da cidade, em mar aberto, lotadas de pequenos condomínios para a classe média e grandes barracas de praia), ou no canto direito do Porto da Barra; exibir um visual mais "comportado", mais "moderno", mais "mauricinho", ou de referência afro, mesmo que a pessoa não apresente qualquer característica fenotípica negra, como no caso de pessoas de cabelos lisos que utilizam uma espécie de cera para fazer dreadlocks. Outros "retratos" de Salvador podem ser construídos, evidentemente. Entretanto, aqui interessa privilegiar elementos que nos permitam distinguir diferentes extratos sociais e que, dessa forma, exemplifiquem relações entre eles.

\section{PARIPE E O ILÊ AXÉ TORRUNDÊ AJAGUN}

É nesse contexto geral em que vivem as 15 pessoas entrevistadas para esta pesquisa, oito delas pertencentes ao Ilê Axé Torrundê Ajagun, terreiro onde realizei três dos quatros anos de trabalho de campo. O Torrundê situa-se no distante bairro de Paripe, como mencionei, a cerca de 40 minutos do centro, de carro, ou mais de uma hora de

10 Poucos anos depois da defesa da tese, este espaço entrou em vertiginosa decadência, tornando-se um local de prostituição notória nos bares e restaurantes que persistiram abertos. Por volta de 2010, a prefeitura entrou em negociação com os lojistas para sua reabertura como centro comercial comum, o que, no entanto, até hoje não ocorreu. 
ônibus. Trata-se de um bairro recém-reurbanizado, ${ }^{11}$ que conta com sistema de saneamento básico (embora o fornecimento de água não seja lá muito regular), tem a maior parte das ruas pavimentadas, ${ }^{12}$ com passeio, iluminação pública e muitos quebra-molas para proteger as crianças que brincam em frente às casas.

Figura 6 - Vista parcial do bairro de Paripe; área próxima ao terreiro

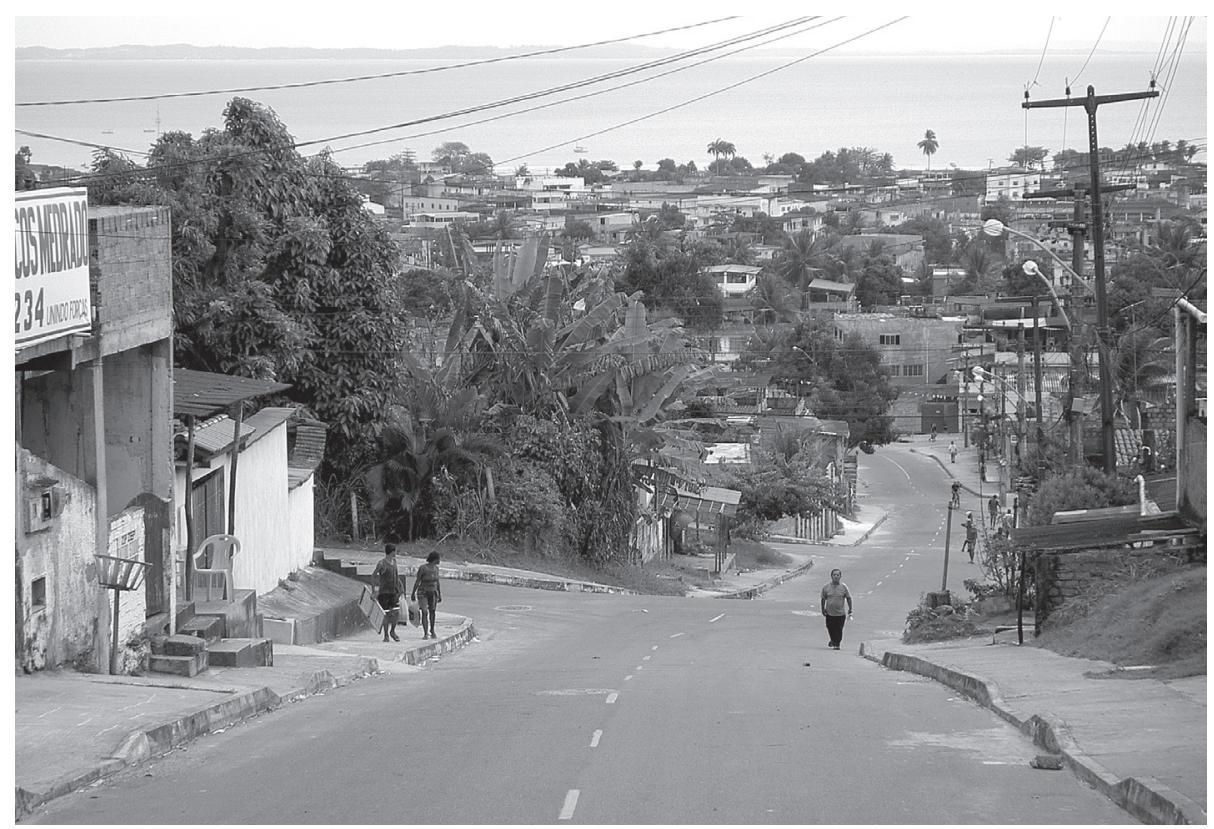

Fotógrafo: John Gledhill.

Na verdade, as ruas são bastante frequentadas também por jovens e adultos que conversam ou andam tranquilamente, além de muitos cães, galinhas e uns poucos cavalos. Há a Prainha, com algumas barracas e muitas canoas usadas por pescadores. Uma quadra de esportes e um campo de futebol de várzea ficam bem próximos ao

11 Quando iniciei o trabalho de campo, em janeiro de 2001, as ruas da área do terreiro estavam sendo pavimentadas. Naquela época, chegar à roça em dia de chuva era uma aventura, pois o ponto de ônibus fica distante quase $1 \mathrm{~km}$ e era preciso andar em meio ao lamaçal das obras.

12 Em maio de 2009, fortes chuvas na cidade levaram ao desabamento de algumas ruas do bairro, incluindo uma parte do terreiro. Descobrimos, então, que nas obras de 2001 não foram construídas galerias pluviais e que toda a água das chuvas retornava ao solo ou juntava-se ao esgoto. 
terreiro, numa área com ares de limite: o asfalto acaba exatamente em frente a um dos portões do Torrundê. À sua direita vemos a imensidão da cidade e à esquerda, um rio e morros cobertos de vegetação, embora existam ainda casas mais à frente. De fato, a roça ${ }^{13}$ está numa região onde ainda se encontra muito verde e seu aspecto é muitas vezes o de cidade do interior e não de periferia urbana. Talvez Paripe seja um dos melhores bairros do subúrbio, pois além de praia e verde tem escolas, uma central de abastecimento de alimentos, um hospital, algumas clínicas particulares menores, um supermercado grande, vários mercadinhos e padarias, além dos incontáveis bares, botecos e vendinhas montadas na janela ou varanda de alguma casa.

O terreiro é relativamente novo, seu barracão ${ }^{14}$ foi inaugurado em 1995 (antes disso, durante um ano foram realizadas sessões de caboclo na pequena área onde hoje está a cozinha), mas já contava, na época do início da pesquisa, com mais de 80 iniciados, entre filhos de santo, ogãs e equedes, ${ }^{15}$ dos quais muitos eram jovens entre 18 e 30 anos. Pai Dary, ou baba Giberewá, é seu chefe e fundador e tinha, no final de 2004, aproximadamente 56 anos de idade e 21 de iniciado. Inicialmente, ele não pretendia abrir seu próprio terreiro e assumiu o cargo de pai pequeno na casa de um de seus irmãos de santo. No entanto, segundo ele conta, quando o orixá tem um desígnio para uma pessoa este acaba se cumprindo: sua parceria terminou com um grave desentendimento e pai Dary decidiu-se a abrir sua própria roça. Sua mãe de santo, Alaíde de Itapoã, ainda chegou a participar dos fundamentos do terreiro antes de falecer. Hoje, há cerca de 10 outras casas atuantes,

13 Os membros do candomblé costumam se referir ao terreiro como "roça".

14 Nome dado ao salão principal, e em geral mais amplo de um terreiro, onde têm lugar as cerimônias públicas.

15 Ogãs são homens que não entram em transe, sendo escolhidos pelas divindades para ocupar cargos religiosos e equedes são seu equivalente feminino. Os números aqui indicados são aproximados e me foram fornecidos por pai Dary, babalorixá do Torrundê, já que é difícil dizer com precisão quantos membros a casa efetivamente possui, pois é comum no candomblé que algumas pessoas "desapareçam" do terreiro algum tempo depois de iniciadas. Outras vão apenas para as principais festas e algumas se mudam para outros estados e países, mantendo contatos com a casa, apesar da impossibilidade de ir ao terreiro. 
filhas da mesma matriz. Entre os dois terreiros que conhecemos ${ }^{16}$ há uma série de elementos rituais comuns: o culto aos caboclos, a festa anual de baba Egun - que ocorre em novembro, próximo ao dia de Finados - e a obrigação de cinco anos de inciação $0^{17}$ são os mais visíveis. No entanto, há uma peculiaridade na iniciação de pai Dary para Obaluaiê, tido por uma divindade jeje. Com isto foram incorporados alguns elementos dessa nação ${ }^{18}$, como certas cantigas para Omolu, Oxumaré e Nanã e alguns termos, por exemplo, vodunsi para designar os filhos de santo iniciados com mais de sete anos. Apesar disso, são os ritmos, cantigas e a nomenclatura do queto que dão o tom geral às cerimônias para os orixás, ao passo que elementos da nação angola demarcam os rituais para os caboclos. Assim, o terreiro apresenta uma combinação de elementos variados que é muito comum em Salvador, à exceção, talvez, da referida influência jeje.

Em dezembro de 2004, o babalorixá estava finalizando a preparação da roça para a grande festa comemorativa dos seus 21 anos de iniciação, com um atraso estratégico, de forma a não causar embaraços para as pessoas que tinham emprego formal ou frequentavam escolas e que por ventura fossem recolhidas na ocasião, já que muitos estariam de férias, como ele me explicou. Para o grande evento, o terreiro sofreu mais algumas ampliações. O terreno vizinho, que já estava comprado, foi incorporado (a área total ficou em torno de $2.500 \mathrm{~m}^{2}$ ), criando um grande estacionamento rodeado por mudas de árvores e arbustos. Mais um banheiro e dois quartos foram construí-

16 Por uma feliz coincidência, a profa. $\mathrm{dr}^{\mathrm{a}}$. Miriam Rabelo realizava trabalho de campo no terreiro da irmã de santo mais velha de pai Dary.

17 Nem todos os terreiros realizam a obrigacção de cinco anos, que é mais característica da nação angola. Os da nação queto realizam obrigações aos um, três e sete anos.

18 Utilizo o termo como referente a diferenças internamente reconhecidas: "Portanto, o termo 'nação' se tornou uma forma de distinguir entre padrões rituais e ideológicos diferentes [...]" e diz respeito a distinções internamente reconhecidas que se refletem nas diversas "ortodoxias" ou "preceitos" relativos à divindade a qual o terreiro foi consagrado e as demais cultuadas, à linguagem ritual (yorubá ou quicongo, por exemplo) e aos "fundamentos", isto é, rituais mais privados de fundação de uma casa, iniciação e sacrifício de animais. (NICOLAU-PARÉS, 1997, p. 36-37) 
dos, além dos que já existiam antes. A casa principal, onde ficava a suíte do babalorixá e onde residia a Iá Morô, ${ }^{19}$ foi reformada e pintada e novas estátuas de caboclos e orixás foram erguidas. Pai Dary é o autor dessas esculturas que representam as divindades tais como lhe apareceram em alguns sonhos. O terreiro já contava com 10 delas e 13 alto-relevos, alguns ainda sendo finalizados. Com a ajuda de filhos e ogãs residentes nas redondezas, além de operários contratados, as obras seguiam em ritmo lento.

Figura 7 - Pátio lateral com a cabana do caboclo à direita e casa principal ao fundo, em 2004; o barracão é localizado no piso térreo da casa

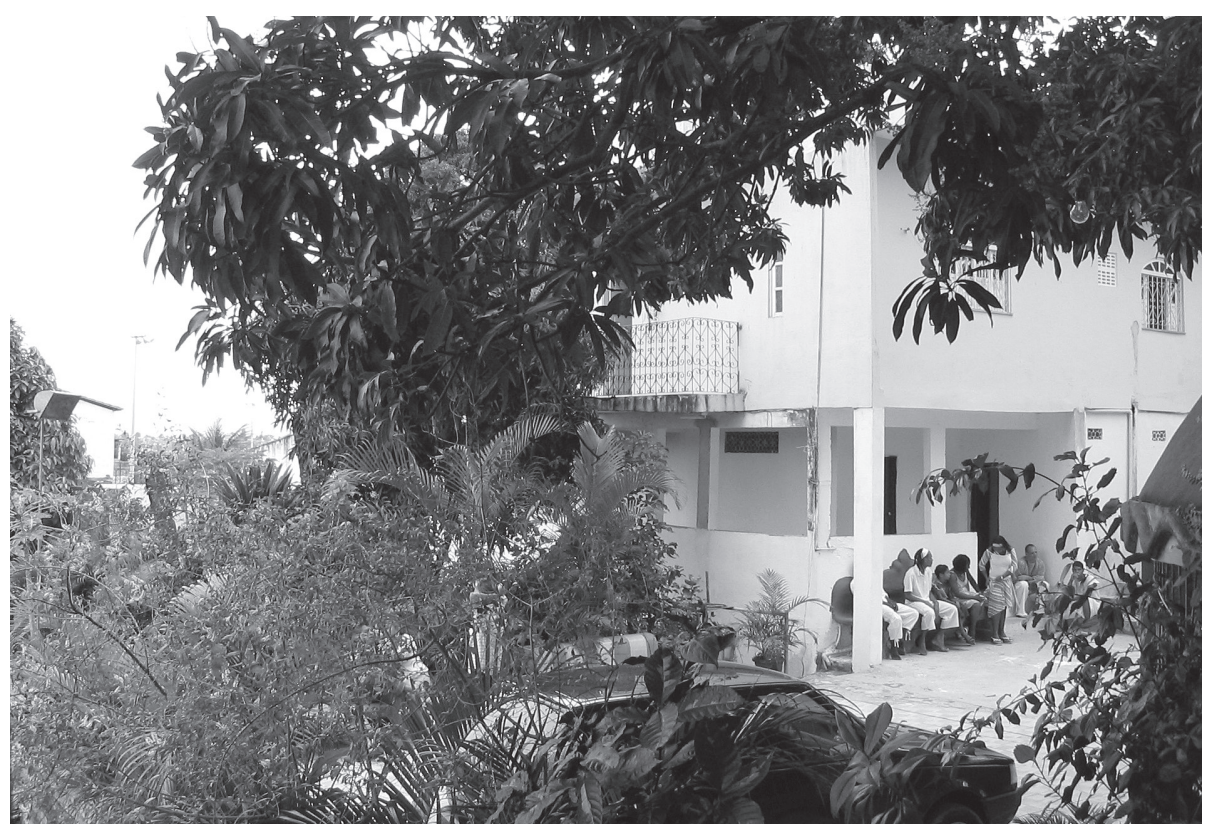

Fotógrafo: Luciana Duccini.

As edificações foram erguidas aos poucos, como costuma ocorrer com terreiros e residências da periferia, muitas vezes com o trabalho dos membros da casa e sem um projeto arquitetônico pré-definido. O próprio pai Dary é bastante afeito aos trabalhos de construção,

19 lá Morô é um cargo no candomblé. Quem o recebe torna-se responsável por todos os cuidados com o Exu da casa, desde as oferendas e a manutenção de seu "altar" (o peji, num quarto separado), até as cerimônias a ele dedicadas, como o padê que precede os rituais públicos. 
modelagem e ferragem, fazendo não apenas as estátuas das entidades que enfeitam o terreiro, mas também as grades e portões que delimitam a cabana do caboclo e os assentamentos de Ossaim e Iroco, ou tão somente protegem janelas. O aspecto geral do terreiro é bastante urbanizado, com piso de concreto, certas áreas com acabamento em mosaico de cerâmica e canteiros para as plantas e árvores. Ainda assim, há espaço para aves e muito verde. Um dos elementos arquitetônicos que julgo mais interessante é a cabana do caboclo: uma área circular construída em volta de uma grande mangueira. Ao invés de paredes, a cabana tem grades em toda a volta e um portão na frente, encimado por uma serpente e uma coruja. A cabana apresenta uma combinação de cores e texturas que nos dizem algo sobre os caboclos. Há o tronco da mangueira, a hera por sobre a cobertura, várias plantas, a predominância do verde e do amarelo, com um pouco de azul, e a escultura em homenagem a Tupinambá, com sua expressão vívida.

Figura 8 - Escultura de Tupinambá

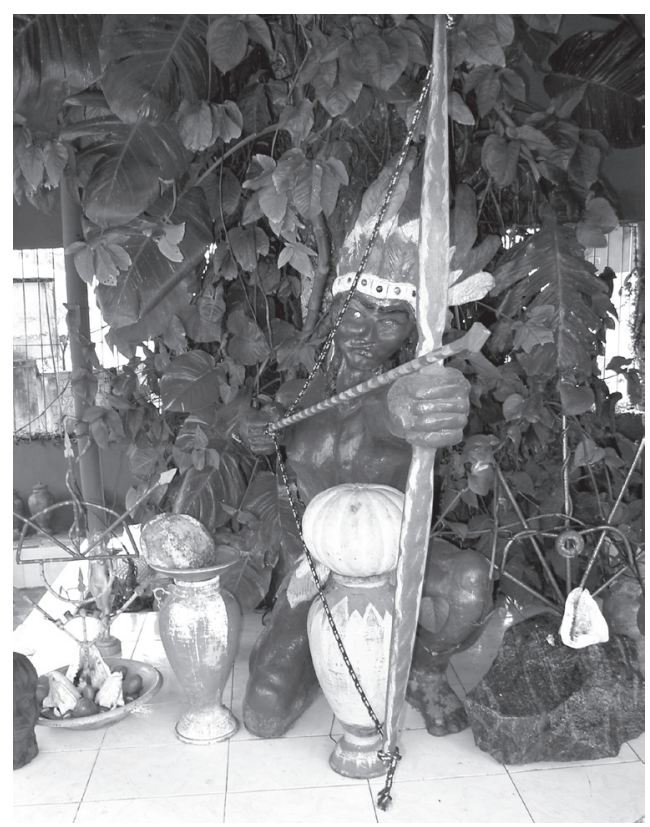

Fotográfo: John Gledhill. 
Alguns orixás também têm seus assentamentos ${ }^{20}$ fora da construção principal, como é o caso de Ossaim e Iroco, já mencionados. Exu possui uma casa só para si, junto de uma das entradas da roça e um assentamento na outra; Ogum e Xangô possuem uma casa um pouco maior, dividida entre eles. Há ainda uma pequena casa para Egun. ${ }^{21}$ Junto do barracão encontram-se, de um lado, o runcó, ${ }^{22}$ com um sabagi ${ }^{23}$ pequeno e do outro um sabagi maior e o quarto de Obaluaiê, dono da cumeeira ${ }^{24}$ que abriga também os assentos de outros orixás consigo. ${ }^{25}$

Pouco mais da terça parte dos membros do terreiro, cuja idade varia entre 15 e 50 anos, não tem empregos formais, trabalhando em barracas de bebidas, fazendo bordados, serviços de manicuros, diaristas e todo o tipo de biscate sem garantias. Se, com isto, eles têm mais disponibilidade de tempo para o terreiro, por outro lado enfrentam dificuldades financeiras. São quase todos negros ou mestiços. Alguns adeptos residem em bairros populares bastante

20 Conjunto de elementos materiais que é agregado quando da iniciação, ou subsequentes obrigações, normalmente mantido no quarto do santo, peji, e onde são colocadas as oferendas ao orixá.

21 O desabamento de 2009 provocou a interdição da casa de Egun - espíritos dos ancestrais e sérios danos à casa de Xangô e Ogum.

22 Quarto de acesso restrito onde se dá a reclusão para a iniciação e para as obrigacções que têm lugar depois de um, três, cinco e sete anos. Cada uma dessas obrigações marca um degrau na hierarquia do terreiro e traz consigo privilégios e compromissos específicos.

23 Área de acesso semirrestrito onde apenas membros do terreiro podem entrar, sendo também acessível a abiãs. Lá se organiza a distribuição do repasto na cerimônia pública, se chama um filho de santo de volta a si e várias outras atividades que devem ficar fora do alcance da assistência.

24 Ponto junto ao teto, bem acima do local no qual, supostamente, está enterrado o axé fundamental da casa (isto é, os elementos rituais utilizados na sua consagração) e onde são postos símbolos do orixá para quem o terreiro foi fundado.

25 Talvez seja útil lembrar que todas as informações aqui apresentadas dizem respeito ao Torrundê exclusivamente e que não será feita qualquer confrontação com outros terreiros, uma vez que o objetivo deste trabalho não é estabelecer um sistema religioso para o candomblé. 
distantes, como Cajazeiras ${ }^{26}$ ou Federação, ${ }^{27}$ compartilhando semelhantes condições de vida. Entretanto a maioria deles, especialmente dos ogãs, reside na vizinhança, o que torna possível sua presença no terreiro mesmo quando não é dia de festa nem de sessão de caboclo. Dessa forma eles representam uma boa ajuda na preparação e execução dos ebós, ${ }^{28}$ além das infindáveis reformas das edificações, como já mencionei.

Outra parte dos membros, pouco menos de um terço, é de profissionais sem nível universitário, mas em melhores condições econômicas, como um taxista, uma policial ou um operário qualificado da Ford, por exemplo, que residem em Paripe, na Liberdade e próximo ao Centro. No entanto, o que me levou a eleger o Torrundê como local de trabalho de campo foi que não apenas pai Dary é médico (e continuou a clinicar até sua aposentadoria), mas que cerca de um terço dos filhos da casa é de profissionais de nível universitário, na maioria jovens entre 25 e 35 anos, que residem nos bairros de Brotas, Boca do Rio, Itapuã e Barra, possuem empregos estáveis nas áreas para as quais se formaram e combinam um cotidiano de classe média com as atividades religiosas. Assim, se apresentou uma boa oportunidade para, ao mesmo tempo, localizar várias pessoas a serem entrevistadas e observar sua presença no grupo religioso, as interações com os outros membros, os conflitos, soluções e associações disto decorrentes, bem como seu comportamento em momentos rituais.

26 Enorme bairro com muitos conjuntos habitacionais no miolo da cidade, afastado do Centro e da Orla.

27 Bairro próximo ao Centro e à Orla. Mescla zonas de classe média e popular.

28 Alguns ebós, como as limpezas, são muito elaborados, exigindo uma grande quantidade de grãos e vegetais picados e arrumados em pratinhos, numa longa sequência; outros exigem ainda o sacrifício de uma ave, além do preparo do banho de folhas, acassás e outros elementos. Contudo, creio que mais importante do que a mão de obra para o preparo de tais coisas é a própria presença de membros do terreiro. Ao assistir um ebó, os filhos de santo incensam o local, cantam e marcam o ritmo com palmas, varem o que cai ao redor e juntam tudo o que foi usado para ser despachado. Há ainda algumas coisas que só podem ser feitas por certas pessoas com certos cargos, como levar os ebós para Exu, por exemplo. Assim, mesmo uma simples limpeza tem seu caráter ritual enfatizado, envolvendo o cliente no grupo de culto. 
A presença dessas pessoas na comunidade de culto apresenta algumas particularidades. Não lhes é possível estar presentes no terreiro no dia a dia, já que tais indivíduos obedecem horários de trabalho formais e, por isso mesmo, enfrentam dificuldades na execução de tarefas para a preparação dos rituais, o que cria uma série de conflitos e fofocas. Por outro lado, têm gerado um incremento de um público de classe média num terreiro relativamente novo, que não tem suas origens nas linhagens mais famosas e "tradicionais" ${ }^{29}$ de Salvador e que fica a quilômetros de distância, nos confins de um subúrbio que muitos membros da classe média nem sabem onde fica.

Para resumir, o Torrundê é um terreiro de grandes dimensões e, como a maior parte deles na cidade, foi (e ainda está sendo) lentamente construído, no que há a participação ativa de membros do grupo religioso, embora esta não seja majoritária. O terreiro não apresenta um aspecto tão luxuoso como o de outros apontados como "classe média”, por exemplo, do Pilão de Prata, na Boca do Rio (cujas áreas externas eram de cimento pintado de verde, com várias estátuas em estilo greco-romano pintadas de dourado e prateado representando os orixás, entre muitos outros elementos decorativos bastante suntuosos), mas sua estética é bastante exclusiva e alegre. As esculturas de baba Dary, numa profusão de materiais como conchas, palha, espelhos e contas, misturam suas cores às plantas da roça e dos arredores. O Torrundê é ainda espaçoso e confortável, quer dizer, há banheiros para o público e para os membros, bebedouro, bancos do lado de fora e quartos para se dormir, embora em esteiras, e estacionamento. Chama atenção a presença de um enorme cinzeiro de areia próximo à porta do barracão que alguns filhos e frequentadores não se acostumam a usar, talvez imaginando se

29 São terreiros que lograram alcançar grande visibilidade na sociedade baiana, como a Casa Branca, o Gantois, o llê Axé Opô Afonjá - este liderando um movimento intelectual antissincrético - e o Alaketu. Mais recentemente, o Bate Folha, de nação angola, vem conseguindo atingir reconhecimento para além dos círculos de iniciados, tendo sido também tombado como Patrimônio Histórico Cultural e recebendo intelectuais, orgânicos ou não, além dos inevitáveis turistas estrangeiros. 
tratar de um vaso ou objeto consagrado. Suas dimensões e "facilidades" o distinguem de muitos outros terreiros de Salvador.

$\mathrm{Na}$ verdade, as feições da roça parecem combinar bem com o babalorixá, e um dos elementos que tornaram meu trabalho de campo mais fácil e agradável foi exatamente uma certa "simplicidade" de pai Dary, que não se importa em ser fotografado usando bermudas e sandálias Havaianas, em meio ao seu trabalho braçal com as estátuas e só exibe seu conhecimento literário do candomblé quando o diálogo com pesquisadores e enxeridos em geral lhe coloca questões bibliográficas. ${ }^{30}$ Sua maneira de receber a mim e a outros pesquisadores que por lá passaram sempre foi paciente, indicando certa compreensão e tolerância para com nossos objetivos e presença - tanto quanto ausência, pelo menos no meu caso atualmente. Um dia, ele me revelou que mantinha esta atitude devido a sua própria experiência na redação de uma monografia para a conclusão do curso de especialização em Saúde Pública.

Contudo, mais interessante, para esta pesquisa, é o fato de um terreiro com uma considerável frequência de classe média estar localizado no distante Subúrbio Ferroviário. Quando perguntei a pai Dary o motivo da localização, ele disse que foi pelo preço do terreno. Por ser numa zona desvalorizada, ele pôde comprar vários lotes e dispor de uma área ampla. Contudo, para as pessoas aqui consideradas, isto significou ter que percorrer um longo trajeto por uma região não somente desconhecida, mas muitas vezes também temida, da cidade. Como comentei rapidamente, o terreiro encontra-se na porção final de um dos últimos bairros do subúrbio o que lhe traz vantagens - como o acesso a plantas - e também desvantagens. Chegar ao terreiro de ônibus, a partir da região central, leva mais de

30 No entanto, isso não impediu que algumas vezes trechos de textos acadêmicos fossem colocados no mural para a leitura de todos. Estes diziam respeito à história e costumes da região da Nigéria, ou às garantias constitucionais ao livre exercício religioso, o que se deu no período em que houve disputas judiciais entre grupos de candomblé e pentecostais em Salvador, entre 2002 e 2003. Hoje, o mural foi retirado da área pública, e as mensagens escritas são afixadas junto à porta da cozinha, isto é, elas se destinam aos membros da casa e não aos olhos dos visitantes. 
uma hora. De carro, o tempo diminui bastante, mas é preciso escolher entre uma rodovia federal e depois uma estrada bastante ruim ou avenida Suburbana, com suas centenas de ônibus, semáforos, ciclistas, pedestres etc. Além disso, há ainda o estigma carregado por essas zonas de ocupação mais pobre e mais irregular. Não quero dizer com isso que todo o Subúrbio Ferroviário tenha o mesmo padrão de ocupação, mas sim que sua imagem é limitada as suas piores áreas, para aquelas pessoas que não conhecem esses bairros, ou seja, muita gente de classe média. A imagem do Subúrbio a que se tem acesso na mídia é aquela das enchentes e deslizamentos de barracos, ou a dos assaltos a ônibus e linchamentos. Assim, como veremos mais adiante, passar a fazer parte de um terreiro como este pode significar também o estabelecimento de novas fronteiras na cidade, pois as pessoas que constituem o foco central desta análise moram, estudaram e, muitas vezes, trabalham em bairros próximos ao Centro, bem urbanizados, ricos em serviços públicos e privados. Passar a ser de candomblé, para elas, significou aprender a convivência com pessoas de outros estratos sociais e em outros espaços da cidade. 


\section{As personagens e seu cenário: distinções de classe e estilo de vida}

Após esta breve descrição do cenário em que se desenrola esta análise, convém apresentar as personagens deste texto, o que iniciarei por pai Dary e pelos demais membros do Torrundê. Antes, porém, é interessante tecer algumas observações mais gerais acerca do grupo de pessoas entrevistadas. Cinco delas tinham entre 24 e 30 anos, mais cinco entre 31 e 50 e os outros cinco entre 51 e 58 anos, mas esta divisão equitativa foi totalmente aleatória, não contendo qualquer intenção de constituir uma distribuição por classes de idade, assim como foi por mero acaso que entrevistei oito homens e sete mulheres. Da mesma forma, a presença de sete ogãs e equedes e oito pessoas que entram em transe também não resulta de uma escolha deliberada. Os critérios iniciais de seleção dos entrevistados foram apenas o nível superior completo, o exercício desta profissão, que a família não fosse de candomblé e a iniciação. Três pessoas, porém, não eram iniciadas, mas decidi incluir os casos de Francisco e de Rosana por representarem relativos "fracassos" de apropriação - e como tal, bons elementos de comparação - e o de Marta porque tive o privilégio de acompanhar sua iniciação ainda recente. 
A apresentação sucinta dos perfis das pessoas entrevistadas antes do restante dos argumentos tem por objetivo permitir que os elementos destacados como relevantes para a análise - distinção frente à família e importância atribuída à educação, entre outros - possam ser considerados a partir das trajetórias de vida das pessoas acompanhadas. Uma vez que suas características pessoais e profissionais não serão tomadas como indicadores de posição social, mas como elementos dentro de um contexto constitutivo de experiências, é importante que não sejam apresentadas de modo isolado. Por outro lado, não seria possível apresentar biografias mais completas dos entrevistados por uma questão de economia de espaço e da manutenção de sua privacidade. Alguns detalhes, excessivamente fáceis de identificar, foram omitidos e, quando precisarem ser referidos, serão considerados fora do contexto dos perfis. É bem verdade que os entrevistados e seus amigos poderão identificá-los sem dificuldades, mas esse não seria um problema já que eles não procuram ocultar seu pertencimento à religião. Minha única preocupação é que estas pessoas não possam ser criticadas por correligionários pelas opiniões que gentilmente compartilharam comigo. Dessa forma, todas as pessoas apresentadas a seguir tiveram seus nomes substituídos por pseudônimos, exceto pai Dary, cuja identidade seria impossível dissimular, a menos que eu criasse um terreiro fictício, e que me permitiu verbalmente manter seu nome em todas publicações decorrentes deste estudo.

\section{PERFIS GERAIS DAS PESSOAS ENTREVISTADAS}

\section{Dary Paim Mota}

Baba Giberewá, como já foi dito, é um médico, clínico geral, de 56 anos que nasceu em Santo Amaro e viveu lá até que sua mãe ficou viúva e se mudou para Salvador com os filhos, quando ele tinha 8 anos. Ele se diz "mestiço" e, de fato, apresenta traços que podem 
ser identificados como negros e, principalmente, índios. Sua família é católica "de batismo", mas a mãe pratica o espiritismo. Com cerca de 17 anos, o próprio Dary começou a frequentar esta religião, mas apenas após ter passado por uma manifestação, pois, até então, ele não acreditava em "nada disso". Com cerca de 25 anos ele foi ao candomblé pela primeira vez, para assistir à saída de iaô de sua cunhada, o que fez sem muita vontade, já que o preconceito era forte e ele pensava que o candomblé era uma espécie de "baixo espiritismo". Ao chegar ao terreiro, ficou muito mal impressionado com o que lá se passava, reforçando assim seu preconceito. Entretanto, ele acabou bolando ${ }^{31}$ já neste contato inicial, o que o deixou apavorado, pois pensou que iria ficar "preso" no terreiro e ser iniciado contra sua vontade.

Passado o susto, ele começou a se interessar, a frequentar o terreiro de mãe Alaíde e quatro anos depois se recolheu para a feitura. De início ele não quis aceitar o cargo de babalorixá e foi ser o pai pequeno de um de seus irmãos de santo, mas cerca de um ano depois, eles começaram a se desentender e terminaram por romper relações. Após esse acontecimento pai Dary abriu o Ilê Axé Torrundê Ajagun, num grande terreno que havia comprado em Paripe com a intenção de fazer um local apenas para as obrigações maiores da casa de seu irmão. Alguns outros irmãos de santo o acompanharam e teve início a roça.

Pai Dary é viúvo e tem apenas uma filha "de sangue" que, porém, é fruto de um relacionamento posterior, pois sua esposa faleceu muito jovem, pouco depois do casamento. Hoje ele tem uma neta e um neto. Sua filha é o único outro membro da família que entrou para o candomblé. Sua mãe e seu irmão, hoje, são frequentadores do terreiro.

Ele divide seu tempo entre a casa no terreiro e um apartamento que possui no Caminho de Areia, bairro da Cidade Baixa, uma área

31 Modalidade de transe na qual a pessoa cai ao chão de bruços, ficando estirada imóvel, e que é tida como um sinal inequívoco de que o orixá deseja sua iniciação. 
antiga da cidade que comporta zonas de classe baixa e média baixa e se encontra bastante desvalorizada comercialmente, apesar de ter grandes sobrados e apartamentos muitas vezes espaçosos e confortáveis. A clínica particular onde trabalha também está localizada na Cidade Baixa e, além disso, pai Dary atende num posto de saúde do Sistema Único de Saúde (SUS). Ele combina as atividades de médico e de pai de santo, procurando "separar" as duas esferas de atividade. Mesmo assim, como o terreiro fica num bairro pobre, é comum que os vizinhos, e até mesmo os filhos da casa, o procurem para uma consulta médica improvisada e gratuita, peçam guias para exames, medicamentos e coisas do gênero. Apenas a título de curiosidade, trata-se de um médico de Obaluaiê, o que não deixa de ter interesse do ponto de vista da mitologia. A primeira entrevista foi gravada em 13 de janeiro de 2001 e uma segunda em 11 de maio de 2001, ${ }^{32}$ ambas no terreiro.

\section{Equede Hortência}

É uma senhora solteira e sem filhos, de 56 anos, nascida no interior de Sergipe, mas que se mudou ainda criança para Salvador, pois seu pai era funcionário público federal. Formada em História e Direito, Hortência foi professora do ensino médio estadual até se aposentar, em 1998, mas continua trabalhando como prestadora de serviços para a Universidade do Estado da Bahia. Residente do bairro de Brotas, a equede pode ser classificada como uma "mestiça clara”, já que não tem a pele escura, mas apresenta outros traços de aparência negra. Sua família também é católica "formal”, isto é, que não frequenta a igreja regularmente, e alguns membros passaram para o espiritismo.

\footnotetext{
32 Tratou-se de um questionário do projeto "Religião, Tratamento e a Transformação da Experiência: Um Estudo das Práticas Terapêuticas no Candomblé, Espiritismo e Pentecostalismo", coordenado pela prof ${ }^{a}$. dra . Miriam Rabelo, minha orientadora, no âmbito do núcleo de Estudos em Ciências Sociais e Saúde (ECSAS), da UFBA, e do qual participei por cinco anos, inicialmente como bolsista de Iniciação Científica da fase 1 do projeto e, posteriormente, como orientanda e colaboradora. Agradeço à prof a . Miriam Rabelo e colegas pela permissão no uso de dados gerados no projeto, bem como por todas as discussões teóricas ali desenvolvidas.
} 
Três de suas irmãs - são oito irmãos, no total - são kardecistas e seu pai também chegou a frequentar um centro, pouco antes de falecer. No momento da entrevista (22 de setembro de 2001) ela já tinha mais de seis anos de confirmada, foi a primeira equede de Obaluaiê da casa. Antes de começar a ir ao Torrundê, ela havia apenas assistido a uma entrega de decá, em 1975, mas não se interessou pela religião. Pai Dary foi quem a convidou para ir conhecer a roça, o que ela fez porque já o conhecia e o considerava uma pessoa séria e respeitosa. A partir daí, Hortência começou a frequentar o terreiro, e quando foi suspensa aceitou imediatamente, pois tinha certeza de que "iria ficar ali" o resto da vida.

\section{Fábio}

Fábio é um dos vários jovens ("filhinhos de papai da Barra", como disse ele) que começaram a frequentar o terreiro logo nos seus primórdios. Na época da entrevista ele tinha 28 anos e nove de feito como filho de Ogum, sendo um dos mais velhos da roça. Fábio morava há dois anos com Ana, filha de Iansã, com quem namorou por oito anos. Eles tinham um filho de 1 ano e 7 meses e já esperavam o segundo. O jovem casal também reside em Brotas. A família de Fábio nunca foi especialmente religiosa, frequentando a Igreja Católica apenas em ocasiões especiais. Na verdade, sua mãe ficou muito perturbada quando o filho adolescente começou a frequentar um terreiro nos confins do Subúrbio Ferroviário e apenas se tranquilizou com o passar dos anos, vendo que o rapaz prosseguia com os estudos, trabalhava, namorava, enfim, tinha uma vida bastante comportada. Entretanto, ela ainda não vai ao terreiro. Formado em Análises de Sistemas, Fábio trabalha numa empresa que desenvolve programas de computador. Antes de se formar, porém, ele teve alguns empregos e estágios que lhe garantiram certa liberdade financeira, como comprar um carro "sem ajuda de pai nem mãe". Na roça, Fábio costuma ser citado pelos mais velhos como filho de santo exemplar. Sua entrevista foi gravada em seu apartamento em 19 de agosto de 2004. 


\section{Ana}

Ana também tinha 28 anos e foi levada ao terreiro por Fábio. Quando gravamos a entrevista, ela tinha seis anos de feita, mas, a princípio, tinha "ciúmes" das atividades religiosas do namorado, pois muitas vezes eles não podiam sair porque ele tinha que estar na roça. Com o tempo ela disse que entendeu e passou a respeitar sua escolha. Aos poucos começou a compreender a religião e terminou por se iniciar também. Em sua família também conviveu com um catolicismo formal e com o espiritismo mais atuante: suas tias são kardecistas e sua mãe chegou a ir a um terreiro de umbanda algumas vezes, "mas só como cliente”. Um avô era ogã suspenso, porém ela nunca foi ao candomblé com ele, nem foi criada em contato com a religião. Tal como Fábio, o Torrundê foi o primeiro terreiro que ela conheceu. Sua família não gostou nem um pouco quando ficou sabendo que ela iria se iniciar. Depois aceitaram melhor e sua mãe já foi a algumas obrigações da filha. Ana é formada em Administração e trabalha como auxiliar administrativa de Recursos Humanos, área de concentração do seu curso. Como Fábio, ela trabalha desde o fim da adolescência e diz que com o casamento as condições financeiras dos dois caíram muito, pois antes não tinham "responsabilidades", todo o dinheiro era só para eles e agora precisam arcar com todas as despesas de carro, casa, filho. Ambos podem ser classificados como brancos. A entrevista com Ana também foi gravada no apartamento deles, em 14 de julho de 2004.

\section{Ogã Pedro}

Pedro também é jovem, tinha 25 anos e três e meio de confirmado, em 4 de setembro de 2002, quando me deu sua entrevista num café do Shopping Iguatemi. Ele é publicitário e trabalha para um grande jornal. Reside no bairro da Boca do Rio com seu companheiro, também adepto do candomblé e membro de outro terreiro. Ele também é branco e também trabalhou durante o curso superior para suprir 
suas próprias “necessidades”. Sua mãe é católica fervorosa, mas chegou a ir a alguns terreiros num passado "remoto", assim como suas tias, na qualidade de "clientes". Tiveram péssimas experiências e deixaram de ir, segundo Pedro, porque elas não compreenderam como se relacionar com as "energias" envolvidas na religião. Por isso, foi complicado lidar com seus pais quando ele decidiu se confirmar. Aos 14 anos chegou a ir jogar búzios, através da família de um colega que frequentava o candomblé, o que atiçou sua curiosidade acerca da religião. Já no terceiro ano da faculdade, outro colega o levou para conhecer o Torrundê. Um pouco depois ele começou a ir com frequência e "bem depois", segundo ele, foi suspenso, não demorando muito para fazer a confirmação, escondido dos pais, dizendo que iria viajar nas férias. Pedro, Ana, Fábio e mais uma dúzia de filhos jovens, todos universitários, com uma exceção, desenvolveram uma relação de amizade que extrapola o ambiente religioso e constituem um grupo bastante coeso dentro do terreiro.

\section{Marta}

Jornalista de 47 anos, negra, Marta nasceu em Porto Alegre, mas já residia há 14 anos em Salvador no momento da entrevista, gravada em 20 de outubro de 2002, num restaurante vegetariano do centro da cidade. Naquela época ela ainda não havia feito a iniciação, o que ocorreu dois meses depois, após ficar quatro anos como abiã do terreiro. Marta só veio a trabalhar depois de formada, sempre com jornalismo.

Sua família teve envolvimento forte tanto com o catolicismo quanto com o kardecismo e sua mãe tornou-se umbandista em seus últimos anos de vida. Hoje, uma de suas irmãs também incorpora entidades dessa religião, mas "tem muito preconceito", o que a impede de se desenvolver como médium. Já adulta, Marta descobriu que a mãe de seu pai era filha de santo e ele mesmo chegou a ser suspenso, mas após a morte da mãe nunca mais foi a um terreiro, desagradou-se da religião e nunca a passou aos filhos. A partir de 
uma única fotografia da avó, vestida ritualmente, ela vinha tentando identificar alguns elementos, como qual seriam o orixá e a nação dessa ascendente. Ainda no Rio Grande do Sul, chegou a assistir a algumas festas de candomblé com colegas de faculdade, mas apenas se aproximou mesmo de um terreiro aqui em Salvador, quando, levada por seu namorado (que, no entanto, não é adepto), conheceu o Torrundê. No momento da redação deste trabalho, Marta tinha um ano e meio de feita e encontrava-se cursando o mestrado em Educação, um de seus sonhos. Atualmente, ela é professora de uma universidade pública.

\section{Rosana}

Este foi um caso atípico. Conheci Rosana nas primeiras vezes que ela foi ao terreiro em busca de tratamento espiritual, em abril de 2001. Branca, com 47 anos, viúva há dois, Rosana foi aconselhada a se tornar abiã com vistas à iniciação. Em maio de 2001 ela me contou sua história na casa de uma das irmãs, em Brotas, onde ela passou a residir. Parte da família é católica e outra parte kardecista, religião que ela mesma praticou por mais de 10 anos e que abandonou por sentir que "um lado da espiritualidade não podia se desenvolver ali". Nenhum dos familiares participava do candomblé, embora uma de suas irmãs iniciasse uma aproximação naquele momento, tendo levado Rosana em busca de ajuda. Rosana estudou Economia, nos idos de 1970, mas casou-se com um engenheiro mais velho, divorciado e nunca desenvolveu uma carreira profissional, trabalhando somente cerca de quatro anos na área para a qual se formou, geralmente em projetos sociais do centro espírita e atividades desse tipo. Por ter viajado muito com o marido, Rosana conheceu várias formas de religião e sempre se interessou por práticas místicas, inclusive visitando um guru indiano cuja seita não sabia identificar. 
Quando começou a frequentar o candomblé ela tinha muito medo de receber um orixá e perder a consciência, "sair do ar" e por estar entre pessoas tão heterogêneas cultural e financeiramente. Por isso, ela sempre procurava minha companhia, conversávamos muito e ela pedia minha opinião com frequência, pois supunha que no papel de pesquisadora eu teria condições de saber "o certo e o errado". Costumava se queixar das broncas que levava, mas não me dava ouvidos quando eu a aconselhava a assumir uma postura mais "diplomática”. Rosana terminou abandonando o terreiro cerca de um ano e meio depois, sem ter conseguido se adaptar, sobretudo à hierarquia religiosa, angariando uma série de conflitos por isso e sendo classificada como "louca" por vários membros da casa.

\section{Pai Robson}

Este outro babalorixá é um irmão de santo - seria "sobrinho", pois foi feito por outro irmão de pai Dary - que mantém relações próximas com o Torrundê. Costuma comparecer às obrigações mais importantes, acompanhado de alguns filhos mais velhos, e participar das iniciações. O próprio pai Dary foi quem o indicou para entrevista, realizada em seu terreiro em 17 de maio de 2001. Na época ele tinha 38 anos, 16 de iniciado, e já havia passado a se dedicar exclusivamente ao sacerdócio. Nascido no interior do estado, Robson veio à Salvador aos 17 anos para prosseguir os estudos. Um de seus irmãos já residia na cidade. Após tentar um vestibular para Medicina e já trabalhando como prestador de serviços para a Secretaria Estadual de Educação, ele optou pelo vestibular em Biologia, pois sempre gostou de áreas relacionadas à saúde, e passou. Continuou, no entanto, a trabalhar na Secretaria e foi, posteriormente, aprovado num concurso. Trabalhou por mais de 12 anos na área, da qual desistiu por suas implicações políticas. Na época já havia sido iniciado.

Sua família era católica, mas passou a buscar orientações no espiritismo quando ele tinha cerca de 11 anos, pois o menino tinha visões e encontrava-se com a saúde debilitada. Em Salvador ele 
frequentou um grande centro espírita e começou a desenvolver algumas atividades em casa. Com o afluxo de pessoas estranhas que começou a receber, porém, ele abandonou a prática religiosa. Sua vida pessoal ficou, então, muito conturbada e ele foi levado por pai Dary ao terreiro de seu irmão. De início, pai Robson ficou chocado com a religião, mas com a insistência do amigo foi assistir a mais alguns rituais. Acabou por receber seu orixá e, em dois meses, decidiu por si mesmo pela iniciação (pensando que esta resolveria os problemas pelos quais passava). O babalorixá evidentemente resistiu, já que a iniciação não é tida como uma "decisão" individual e somente a "necessidade" colocada pelo orixá resolveu a disputa. Hoje ele mesmo é contra iniciações feitas como a sua, pois ele não estava familiarizado com o candomblé. A família de Robson não foi favorável à sua iniciação, mas terminou aceitando, embora seu pai tenha falecido sem jamais ir ao terreiro.

Estas oito pessoas são, portanto, ligadas ao Ilê Axé Torrundê Ajagun. A seguir apresento mais quatro entrevistados que pertencem todos a um grande terreiro de Salvador e que foram contatados através de uma amiga comum a todos nós. Os outros personagens participam de casas diversas, não tendo relações entre si.

\section{Equede Antônia}

Antônia é uma psicóloga, negra, com mestrado em Ciências Sociais, que tinha 48 anos à época da entrevista, concedida em seu apartamento em Amaralina, em 10 de junho de 2001. Antônia tinha, então, 10 anos de confirmada. Nascida e criada em Salvador, sua família paterna era extremamente católica e a materna seguia estritamente o espiritismo kardecista, o qual o pai veio a abraçar posteriormente, ao passo que sua mãe tornou-se “sincrética até dizer chega!”. Pessoalmente, no entanto, ela apenas freqüentou a Igreja Católica, levada pela família e nunca conseguiu abraçar o espiritismo, embora tenha passado por sessões de passes. Há mais de 20 anos, Antônia foi levada por uma amiga ao terreiro ao qual pertence hoje para fazer uma con- 
sulta aos búzios porque passava por um momento conturbado em sua vida pessoal: o iminente divórcio, problemas de saúde, familiares e financeiros. Antônia fez alguns ebós, começou a nutrir certa amizade pela mãe de santo e a frequentar as festas. Foi ficando, ficando, e "quando eu vi, tava de saia". Passou ainda quatro anos como "abiã", quer dizer, não iniciada, até ser suspensa equede e mais seis para se confirmar de fato. Para Antônia, o candomblé foi um caminho que seguiu com seus “próprios pés”.

\section{Irene}

Irene é uma professora com mestrado em Educação, também negra, que tinha 58 anos em 26 de junho de 2001, quando a visitei em seu apartamento no Itaigara. Nascida no interior da Bahia, numa família de boa situação socioeconômica, ela mudou-se para Salvador na adolescência para estudar e, de repente, se viu órfã com as quatro irmãs, todas mais novas. Aquele foi um momento de dificuldades. Ela e as irmãs foram morar no Subúrbio Ferroviário, mas Irene conseguiu prosseguir nos estudos, fez magistério e foi ser professora de nível básico. Nove anos depois, já casada, voltou a estudar, formando-se em História, mas não gostou de ser professora de nível médio. Chegou a abrir uma pequena escola no Subúrbio, que cresceu, mas em alguns anos "fechou com esses planos Verão, plano isso, aquilo", "mas o sonho ficou" e ela sempre esteve envolvida com questões de pedagogia e da situação dos negros na sociedade (sem ter se tornado uma militante, propriamente), participava de encontros e seminários e acabou por se envolver no ambiente artístico e intelectual da cidade.

De família muito católica, Irene frequentou a igreja e participou de grupos carismáticos até cerca dos 35 anos, quando ficou viúva. Nessa época foi a uma ou duas festas de candomblé, mas seu interesse era pela "cultura africana" e conheceu o terreiro que frequenta através de uma amiga há cerca de 20 anos, devido a esse "interesse cultural". Levou também seu então namorado (e atual companheiro), que foi 
suspenso ogã logo depois e se confirmou. Assim, após passar dois anos com todos os privilégios de "mulher de ogã", de repente Irene se viu como abiã, trabalhando na roça. Ela ainda levou cinco anos para se iniciar. Hoje já tem 15 anos de feita e diz não ser capaz de lembrar quando foi que seu orixá se manifestou pela primeira vez. No seu caso, diz ela, o orixá chegou "também pelo intelecto".

\section{Ogãa João Alfredo}

Nascido no interior do Maranhão, dr. João Alfredo mudou-se para Salvador em 1962, para estudar Medicina, e nunca mais abandonou a cidade. Foi professor de sua especialidade, aposentou-se, mas continua atendendo numa clínica particular e no SUS, o que, para ele, é uma forma de contribuição social. Solteiro aos 57 anos, reside num dos bairros centrais mais valorizados da cidade, a Vitória. Sua família, de origem mais pobre do que os outros entrevistados, se beneficiou com sua formação universitária, passando por um processo de ascensão social na sua geração. De formação familiar católica, ele contou que acompanhava as atividades religiosas "de muito bom grado", mesmo depois de ter se mudado para cá, onde conheceu o candomblé. De início ele assistiu a algumas festas em terreiros que as anunciavam nos jornais, mas “chegava lá, não me identificava, assistia, ia embora”. Até que, uma noite, atraído pelos sons dos atabaques, entrou numa cerimônia do terreiro ao qual viria a pertencer, cerca de 15 anos depois, pois sem ter referências exatas não conseguia encontrar novamente a casa que tanto o impressionou. Um dia o acaso, na forma de um paciente, o levou de volta ao terreiro, que ele começou a frequentar regularmente. Nessa época, chegou a ir também a um centro espírita, no qual esteve por pouco tempo, apenas para uma terapia de desobsessão ${ }^{33}$ sem, contudo, ser “cativado" pela religião. Cerca de

\footnotetext{
3 No espiritismo kardecista a obsessão é uma relação entre uma pessoa e um espírito, ou entre dois vivos, que assume caráter patológico através de pensamentos obsessivos e negativos. Deve ser tratada em sessões onde o espírito perturbador é convocado a se apresentar para ser doutrinado e aconselhado a buscar sua própria evolução espiritual.
} 
um ano e meio se passou até que ele fosse suspenso, e em mais um já estava se confirmando, o que ocorreu 10 anos antes da entrevista que ele me concedeu, em 14 de junho de 2001, no próprio terreiro.

\section{Ogã Ernesto}

Também médico, dr. Ernesto tem 55 anos de idade e 10 de confirmado. Nascido em Salvador, foi criado no Rio de Janeiro, fez especialização em São Paulo e aos 29 anos, já casado com a primeira esposa, voltou a residir em Salvador. Adotado por uma senhora viúva de boas condições financeiras, Ernesto cresceu numa família de médicos, embora tenha mantido a convivência com o pai biológico, de origem menos favorecida. Com isso disse que nunca "escolheu" sua profissão, pois sempre desejou fazer medicina. Sua história apresenta particularidades interessantes. Seus pais, comunistas, sempre foram ateus e ele cresceu sem formação religiosa. Além disso, foi um negro que sempre estudou num ambiente majoritariamente branco, o que, para ele, colocou a cor como elemento importante de sua identidade. Sua agenda de trabalho é bastante intensa, pois atende numa clínica particular, num hospital do Estado e ainda num posto de saúde de um município do interior. Hoje ele reside em Nazaré, no Centro da cidade, com sua segunda esposa e os três filhos desta. Tem três filhos seus já adultos, sendo que dois moram no Rio. Sua esposa também trabalha na área de saúde e pertence ao candomblé, o que, segundo ele, foi um elemento a mais de atração entre eles.

No início da década de 1990, por ter acabado de retornar de Angola, onde trabalhou por três anos e meio, foi levado por uma colega de trabalho para conversar com uma "amiga" que, na verdade, era mãe de santo. Ernesto acabou fazendo uma consulta, começou a ir visitar a mãe de santo, por sentir afinidades com ela, a acompanhar as festas no terreiro e logo foi suspenso ogã. Para se confirmar, no entanto, ele levou mais de um ano e, ao ser entrevistado, tinha 10 anos de iniciado, mas acredita que alguém "que veio chegar no candomblé depois dos 40 anos de idade" não pode ser um "crente convencional”. 
Antônia, Irene, João Alfredo e Ernesto, como foi dito, pertencem ao mesmo terreiro e à mesma rede de amizades lá dentro. Na verdade, a primeira e o último já se conheciam antes de se reencontrarem no grupo religioso.

\section{Equede Helena}

Helena é uma paulistana formada em Comunicação Social que se mudou para Salvador na década de 1970 com seu, então, companheiro e depois marido. Hoje divorciada, ela reside com seu único filho no Rio Vermelho, na casa onde me concedeu uma entrevista, em 27 de novembro de 2000. De família bastante católica, com alguns adeptos do kardecismo, Helena já havia ido, com colegas da faculdade, a rituais de umbanda e a festas de candomblé em São Paulo, porque gostava da "comida e da música". Em seu caso, o encontro com o candomblé pode ser considerado como parte de um percurso de uma "busca" não necessariamente religiosa, mas "cultural”, num sentido mais amplo, que levou muitos jovens a procurar na Bahia as raízes "autênticas" do país, principalmente se considerarmos que ela foi uma estudante da Universidade de São Paulo (USP) na década de 1970 exatamente como descrito por Prandi (1999, p. 102). Assim, desde que chegou à Salvador ela manteve contato com membros de terreiros e artistas locais, mas somente veio a frequentar uma casa quando descobriu que um de seus conhecidos era pai de santo. Lá, foi suspensa e se confirmou há mais de 25 anos. Dentre os oito entrevistados que têm filhos, Helena foi a única que criou o seu no terreiro e com 22 anos ele já havia sido também suspenso.

\section{Paulo}

O único entrevistado a ser iniciado ainda criança, aos 9 anos, este rapaz nascido no interior de Sergipe constitui uma exceção entre os demais. Devido a um grave acidente, Paulo ficou entre a vida e a morte. Sua avó materna, após ter tentado todos os grupos de oração e a Igreja Evangélica da pequena cidade onde residiam, terminou 
por recorrer a uma mãe de santo, levada por uma vizinha. Após a recuperação surpreendente do menino, ela cumpriu o prometido e tratou de organizar sua feitura, às escondidas, porém, porque as famílias "tradicionais" e extremamente católicas jamais aprovariam tal atitude. De fato, aos 14 anos Paulo deixou a casa paterna, em Aracaju, pois seu pai descobriu sua ligação religiosa. Formado em História, Paulo começou a trabalhar como professor antes mesmo de terminar o curso. Casou-se com uma colega, com quem tem uma filha, e residia em Salvador, em 2000, para fazer o mestrado em História, concluído um ano mais tarde. Paulo era professor universitário em Aracaju e planejava, então, seu doutorado. Devido à sua iniciação precoce, Paulo, em 7 de abril de 2000, tinha 30 anos de idade e 21 de iniciado, ocupando o cargo de babalaxé do seu terreiro. Nos encontramos para a entrevista no apartamento que ele dividia com outros estudantes no Campo Grande, onde passava a metade da semana devido às aulas.

\section{Francisco}

Em 06 de junho de 2000, quando o entrevistei no pátio de uma biblioteca pública, Francisco tinha 23 anos, era recém-formado em História, dava aulas na rede estadual e residia no Barbalho com sua mãe, também professora, o padrasto dentista, um irmão e uma avó. Anos depois, ele havia concluído um mestrado, cursava o doutorado e residia com seu companheiro nos Barris, antigo bairro de classe média próximo ao Centro. A prática religiosa mais efetiva em seu ambiente familiar foi o espiritismo kardecista, que chegou a frequentar levado pela mãe, mas onde nunca se sentiu bem, não desejando participar efetivamente do centro. No fim da adolescência, Francisco começou a ler sobre candomblé e, movido pela curiosidade, tentou várias vezes marcar consulta em um grande terreiro. No final de 1997 foi levado pela mãe de um amigo a um terreiro no bairro do Portão, em Lauro de Freitas, onde foi feito o jogo de búzios. Ele sentiu muita afinidade com o babalorixá e começou a frequentar a casa e a assistir 
às festas, sendo suspenso pouco depois. Não chegou a se confirmar, como gostaria, no final de 2001. Começou a divergir de seu pai de santo, sobretudo, pela falta de sistematicidade nas regras de comportamento dentro do candomblé. Acabou abandonando o terreiro em 2002, dizendo que o candomblé não deixará de ser sua religião e que ele talvez fosse procurar outra casa. Embora continuasse a frequentar terreiros, Francisco não se iniciou efetivamente.

\section{Luciana $^{34}$}

Apesar de não ser um dos "nativos”, sem dúvida, sou um dos protagonistas deste trabalho. Paulista, formada em Comunicação Social e estudante de Ciências Sociais, em 1999, aos 29 anos, transferi-me para a Universidade Federal da Bahia, onde posteriormente ingressei na pós-graduação em Ciências Sociais. Em junho daquele mesmo ano assisti à primeira cerimônia de candomblé em toda minha vida, na Casa Branca, levada pelo prof. dr. Ordep Serra. A impressão causada foi tão profunda que decidi, "de dentro ou de fora", tentar compreender aquele mundo tão estranho. A via "científica” me pareceu mais fácil e iniciei o trabalho de pesquisa como bolsista da prof ${ }^{a}$. dra $^{a}$. Miriam Rabelo. A escolha do tema deste projeto, membros da classe média que entraram no candomblé, pode ser fruto do impacto que os primeiros contatos com a religião causaram sobre minha pessoa, uma vez que sou, eu mesma, uma filha "branca" da classe média e universitária de São Paulo, em especial quanto aos preconceitos contra as religiões afro-brasileiras, vistas ora como superstição de pessoas ignorantes, ora como perigosa degeneração do espiritismo.

Minha pergunta inicial, então, poderia ser refeita da seguinte maneira: de que forma pessoas como eu se tornam membros do candomblé? A partir disso, uma série de questões teóricas e recortes foram sendo feitos, mas desde já fica claro que não cabe aqui uma

34 A decisão de apresentar minhas características pessoais reflete algumas discussões de Silva (1998) acerca da inserção do pesquisador em campo e também traz uma influência dos trabalhos de Stoller (1989). 
distinção rigorosa entre "nativo" e "pesquisador". Por alguns anos depois do trabalho de campo ainda participei do Torrundê, embora marginalmente, na qualidade de abiã, o que me fez compreender que, na verdade, há muitas formas de se conhecer algo e estas duas, a religiosa e a científica, nem se excluem, nem eliminam outras. Apesar disso, este trabalho não consiste num esforço de pôr estas duas perspectivas em diálogo, pois isso demandaria um envolvimento religioso muito mais profundo do que eu tive.

\section{ALGUNS PONTOS DE CONVERGÊNCIA}

Embora todos os casos de que disponho apresentem particularidades próprias, é possível distinguir alguns temas recorrentes. Quase todas as pessoas aqui retratadas - 12 delas - mencionaram o desenvolvimento de uma forte relação afetiva diretamente com o pai ou mãe de santo de seu terreiro, mesmo aquelas que não a citaram como o motivo para a adesão à religião; para seis delas a amizade já existia ou se consolidou antes do vínculo com a religião e foi apresentada como um de seus motivos. Para oito dessas pessoas o terreiro no qual se iniciaram foi o primeiro que conheceram e elas só passaram a frequentar outras casas acompanhadas por demais membros do grupo religioso. As outras sete já haviam ido a alguns terreiros, mas sem estabelecer um contato mais prolongado ou próximo, muitas vezes tendo ido a uma única festa, levadas por um difuso "interesse cultural”, ou como Francisco ou Pedro, que já haviam ido a uma consulta. Ou seja, o percurso religioso desenvolvido não incluiu um trânsito por diversos terreiros, a não ser nos casos de Marta, Helena e João Alfredo, o que levanta a hipótese de que a relação pessoal com o chefe da casa tenha sido decisiva para o ingresso.

Entretanto, a frequência quase que exclusiva a somente um terreiro não deve nos levar a pensar numa grande proximidade com todos os seus membros: apenas quatro dessas pessoas têm um envolvimento mais próximo com todo o grupo de culto. Trata-se dos dois babalorixás - o que é óbvio - de Irene, que além de ser filha de santo 
desenvolve um trabalho pedagógico no terreiro há mais de 13 anos e de Helena, para quem o aspecto comunitário da religião é um dos que mais lhe agradam. A proximidade entre pessoas muito distintas entre si chega mesmo a ser citada como um problema. Pai Robson disse que o mais difícil foi adaptar-se a essa situação e às regras do terreiro, mesmo que com o passar dos anos isso tenha se convertido em algo positivo para ele. Na verdade, quase todos os entrevistados contaram ter tido certa dificuldade de convívio e com a hierarquia religiosa, não tanto pelo fato de terem que "se submeter" a ela, mas por desconhecê-la e muitas vezes "passar na frente" de quem não podiam.

O desconforto na convivência com outros participantes reaparece, com mais ou menos franqueza, nas falas de todos os entrevistados. No caso de Rosana era ainda mais evidente, já que ela frequentemente comentava comigo os constrangimentos que sentia e disse que confiava em pai Dary por ele ser "uma pessoa como nós”. Francisco queixou-se do ambiente de fofocas e afirmou comparecer por motivos estritamente religiosos, não se envolvendo com os outros adeptos:

Eu vou ao candomblé com um objetivo único. [...] Ali eu vou assim, a coisa mais importante que tem na casa de candomblé pra mim não são as pessoas, são os orixás.

Paulo também, apesar do alto cargo que ocupa, quando falou de sua intimidade com a família biológica de sua ialorixá, contrapôs esta relação com o distanciamento que mantém dos outros filhos de santo:

Nem eu, nem eles também gostam que... não, né? No barracão nós somos educados, pra isso. Cada pessoa tem sua particularidade, nós somos irmãos aqui dentro. Lá fora, cada qual tem a sua vida. [...] Eu tenho uma relação muito mais próxima com a família [biológica] da minha mãe de santo, de sair, passar carnaval junto, de ir pra show junto, de passarmos final de semana junto e acamparmos junto, do que com irmão de santo. [...] Tem algumas irmãs de santo que às vezes fazem assim, uma feijoada, um churrasco. E convida a gente pra ir. Aí eu vou pra roça de santo, se a minha mãe de santo for, eu vou. Se ela não vai, eu não vou. 
Hortência contou-me que as pessoas muitas vezes a chamam de orgulhosa, mas que isto se deve ao fato de ela preferir manter-se mais fechada, sem procurar se envolver com os demais participantes, o que ela atribui a uma idiossincrasia própria, mas admite que lhe poupa aborrecimentos. Somente Helena tem opinião diversa. Para ela, o terreiro é um espaço onde podemos atuar em conjunto, para o benefício de outras pessoas, ajudando concretamente aqueles que nos são próximos, possibilidade que ela considera muito restrita na sociedade de hoje. Como foi dito, dentre os oito entrevistados que têm filhos, ela foi a única que socializou o seu no interior do grupo religioso desde criança. Mesmo Irene, que tem um bom envolvimento com a comunidade, não evidenciou ter feito qualquer esforço para que seus filhos ou netos viessem a participar da religião. Fábio e Ana divergem nesse ponto, pois ela é da opinião de que a religião é um assunto pessoal e que seus filhos devem decidir sobre isso por si próprios quando forem maiores, mas ele acredita que a religião, qualquer que seja, é parte da educação moral de uma criança e que, portanto, os pais devem criar os filhos no seu ambiente religioso, embora aceite que adultos mudem por escolha própria. "Se eu acho o candomblé bom pra mim, como não vai ser bom para meu filho?”, diz ele.

É interessante pensar na situação de pessoas cujas famílias pertencem ao candomblé. (SANTOS, 2003; RABELO, 2008a) Para elas o terreiro é um lugar onde se chega levado por familiares e as relações de intimidade muitas vezes se sobrepõem, a família de santo ${ }^{35}$ se combinando com a família biológica. Assim, é evidente que não é necessário estabelecer uma afinidade pessoal com o chefe da casa (embora isto costume ocorrer devido às relações próximas durante a iniciação), pois a mediação entre o indivíduo "novato" e o grupo já se encontra traçada pelos familiares. Além disso, é usual a emergência

35 Termo pelo qual se designa o grupo de iniciados de um mesmo terreiro e de terreiros que possuem a mesma origem, pois se trata de "pais" e "mães", "filhos" e "filhas" e, por extensão, "avós" e "tios" e "tias", embora estes últimos não sejam utilizados internamente, mas apenas para explicar relações. Para um estudo das relações de parentesco simbólico em terreiros ver Lima (2003). 
de um discurso da "necessidade": "Ao orixá não se chega pelo amor, mas pela dor”, é um ditado comum e a iniciação é muitas vezes tida como um destino inescapável, determinado antes do nascimento pelas relações míticas e pela ancestralidade que se manifesta diretamente através da incorporação. Nesses casos, é costumeiro haver uma certa "peregrinação" por terreiros conhecidos até se encontrar uma solução satisfatória. É óbvio que muita gente gosta de ir aos terreiros - que são vistos também como uma forma de lazer em áreas pobres -, mas gostar não significa ver a própria participação como uma marca distintiva pessoal. Tampouco é possível afirmar com isso que há uma equação do tipo "membros de classe média = famílias de outras religiões = opção individual" versus "membros pobres = família de candomblé = não opção”. Entretanto, é preciso levar em conta que, por um lado, o recorte desta pesquisa excluiu os membros de classe média cujas famílias já eram de candomblé, por razões de delimitação da construção do objeto. ${ }^{36}$ Por outro lado, a maior parte dos adeptos desta religião ainda é de pessoas pobres, portanto, é justo imaginar que a maior parte das famílias que frequentam terreiros, e levam seus filhos e sobrinhos, seja deste extrato social.

Assim, no caso do recorte em questão, o vínculo religioso é encarado realmente como um assunto "de foro íntimo", uma opção individual, mesmo que seja preciso nuançar essa noção de "escolha”, já que ela não se dá apenas em função de avaliações refletidas, mas, sobretudo de emoções e relações afetivas. Se nos voltarmos para as origens religiosas desses adeptos, podemos também notar que o catolicismo e o espiritismo aparecem exatamente como religiões familiares, ao passo que o candomblé vai ser a opção que o sujeito opera por si próprio, mesmo quando é levado por uma "necessidade" ou pelo seu orixá. A umbanda foi mencionada em pouquíssimos casos e, às vezes, com críticas à relação "utilitária” dos parentes com a religião.

36 Além disso, essa situação me parece ser atípica. No Torrundê não encontrei um só caso e, pessoalmente, travei contato com apenas duas pessoas que não foram entrevistadas por esse motivo. 
É interessante a total ausência de antecedentes evangélicos ou mesmo protestantes nas famílias.

Antônia, a equede que procurou o terreiro em busca de solução para seus problemas pessoais, manifestou explicitamente este ponto quando disse que, na opção pelo candomblé, foi a primeira vez em que se sentiu tomando uma decisão que só dizia respeito a ela, independente de sua família, “com meus próprios pés”, como disse. Para estas pessoas, não há uma coação para se frequentar o terreiro, como Marta deixou claro, ao comentar que esta religião não atrai pela propaganda:

Luciana - Não é fazendo proselitismo?

Marta - Não, não, não tem, vai quem quer, entendeu? É aquela história, se tá com medo, por que tá? Por que veio, né? A porta tava aberta, entra ou sai na hora que quiser, né? Isso eu acho assim, tem uma coisa de democracia, de direito, de escolha, muito [...].

Para Pedro, a ida ao terreiro é encarada quase como lazer, pois é preciso sentir "prazer" na prática religiosa, pois em sua opinião, "ir e ficar lá de má vontade" afeta negativamente a relação com os orixás. Isso, porém, não quer dizer que os entrevistados desprezem a força das divindades em tal processo. A explicação de equede Hortência é exemplar desse "equilíbrio":

Ele [pai Dary] é uma pessoa realmente decente, pessoa excessivamente escrupulosa, então, quando ele me convidou pra vir até aqui, eu vim com a maior tranquilidade sabendo que tava num lugar, entendeu? Onde eu poderia vir realmente. Isso pesou. Agora, claro que eu tinha alguma ligação com os orixás, porque se eles botaram pai Dary na minha vida, entendeu? Como amigo, e ele me trouxe aqui, e isso claro que tem, isso é um indicativo de que eles tavam me trazendo pra aqui, tanto que quando eu fui suspensa, no mesmo dia eu tive aquela tranquilidade de que eu ficaria aqui. ${ }^{37}$

37 Observe-se que, neste caso, minha pergunta foi sobre a importância de conhecer pai Dary anteriormente e não fazia menção aos orixás e seus desígnios. 
Reconhece-se o chamado dos orixás na trajetória de ligação com o candomblé, admite-se um "destino" que, devido a uma ancestralidade vaga e incerta, ${ }^{38}$ leva para dentro do terreiro. Ao mesmo tempo, não se abre mão da agência individual. Como veremos mais adiante, esse "equilíbrio de forças" encontra-se presente também nas trajetórias escolares e profissionais e permite entrever o outro lado da questão: como os entrevistados veem suas famílias em relação à religião?

Quando questionados a respeito da reação de seus familiares à sua decisão pela iniciação, em geral, esta é retratada como muito negativa. Os familiares tentaram dissuadi-los de sua atitude, criticaram-nos abertamente, ou chegaram mesmo a romper com os entrevistados por causa disto. Entretanto, todos eles parecem ter prazer em narrar como, com o passar dos anos, a resistência foi diminuindo, tornando-se uma tolerância tácita, uma aceitação tranquila ou, até mesmo, a frequência aos terreiros para as obrigações dos entrevistados ou para a realização de trabalhos, embora seja preciso conviver com as "brincadeiras" e ironias acerca disso, como ser chamado de "pai de santo" pelos pais ou irmãos. De modo geral, os familiares são considerados menos tolerantes do que os próprios entrevistados. Assim, também as posições assumidas pelas famílias permitem a demarcação de uma posição singular o que, por sua vez, favorece a ênfase na opção individual. Esta situação pode ser nuançada pelo caso de Paulo, iniciado ainda criança, quando conta como rompeu com seu pai pela religião, aos 14 anos: "Onde cabe meu santo, me cabe, onde não cabe meu santo, também não me cabe”. Neste caso, a família biológica é que parece ter sido objeto de "escolha" e não o candomblé, já que o entrevistado preferiu viver por 4 anos com uma irmã de santo bastante pobre a ter que abandonar o terreiro. Entretanto, como veremos, esta diferença não opõe Paulo aos demais, pois ele também se destaca do meio familiar pela religião. Seu caso nos

38 Amaral e Silva (1993, p. 101-102) mostram como pessoas "brancas" do candomblé de São Paulo podem recorrer a teorias sobre o surgimento da humanidade na África para legitimar sua presença no terreiro, já que não possuem a pele negra que remeteria a uma origem africana. 
permite evidenciar o sentido que deve ser atribuído à "opção": tratase de uma escolha em aberto, realizada e atualizada no percurso, envolvendo também afetos e experiências imediatas. Não se trata propriamente de um projeto deliberado e uma busca consciente, embora em casos como o de Francisco se chegue bem perto disso. Não seria este o caso em qualquer processo de conversão, afiliação múltipla e trajetórias religiosas em geral? Decerto que sim. Contudo, o que as posições narradas evidenciam é a importância atribuída à ideia de que "se pode escolher".

Temos aqui outro ponto: para as pessoas pesquisadas a opção religiosa é exclusiva, exceto no caso de Paulo, que afirma gostar de ir à missa de vez em quando. A postura geral parece ser a de um respeito distanciado das outras práticas religiosas. Assim, os entrevistados não negam a veracidade do que é pregado em outras religiões (salvo nas igrejas neopentecostais que fazem do candomblé seu alvo preferencial e cujas práticas são abertamente desqualificadas como mera forma de ganhar dinheiro), mas criticam posturas morais, interpretações teológicas, as relações entre as pessoas e não frequentam outros cultos, contrastando com a prática muito usual de se frequentar cultos diversos simultaneamente. Essa prática é condizente com a recusa do sincretismo com o catolicismo e a umbanda (o sincretismo entre diferentes nações de candomblé é nomeado como tal e aceito por muitos membros do Torrundê), o que Silva (1999) já havia apontado como um movimento contemporâneo em direção a uma maior coerência religiosa que tem como principais protagonistas os adeptos mais intelectualizados das religiões afro-brasileiras. No entanto, é necessário observar que o discurso das pessoas entrevistadas sobre concepções religiosas encontra-se carregado de expressões e ideias de outros universos religiosos, sobretudo, do espiritismo kardecista. A incorporação é muitas vezes referida como manifestação, fala-se muito de mediunidade e alguns entrevistados expressaram a crença numa evolução espiritual proporcionada pelo culto correto aos orixás, como Fábio, e em reencarnação, como Ana, embora ela acredite que é pos- 
sível a um ser humano voltar como animal, o que estaria mais próximo do hinduísmo e do budismo do que do candomblé. Mais do que uma contradição interna, o que temos aqui é uma das expressões da ambiguidade que marca toda existência concreta.

Gostaria, então, de sugerir que a adesão ao candomblé, nos casos em que analiso, pode ser compreendida como um processo de identificação que possibilita ao sujeito uma singularização frente à família. Passar a ser parte de um terreiro colocou as pessoas acompanhadas numa posição distinta - e, às vezes, antagônica - a de seus familiares. Este, porém, é apenas um eixo no qual podemos situar a iniciação. Ele pode ser entrecruzado com mais dois outros, o eixo das experiências religiosas que o candomblé possibilita, com sua noção de pessoa própria e o da distinção interna à classe média urbana, extremamente heterogênea, o que será o objeto dos próximos capítulos. Para analisá-los, porém, é preciso levar em consideração a constituição do que vem a ser essa "classe média".

\section{QUE CLASSE MÉDIA É ESSA?}

Porque essa coisa da classe média aqui no Brasil, eu acho meio complicada, porque as pessoas vivem como se fossem, mas não são, porque estão presas ao cartão de crédito e ao limite especial do cheque, né? Então isso pra mim não é classe média. Pra mim classe média seria a pessoa que tem condições de ter uma qualidade de vida boa, poder pagar o que o Estado não dá naturalmente, como um bom plano de saúde etc, sem tá presa ao cartão de crédito e ao limite. (Marta) ${ }^{39}$

A partir dos perfis apresentados acima, em que medida se pode dizer que estas pessoas pertencem a uma classe média? Segundo Albuquerque, não se pode “[...] contar os membros de uma classe social

39 É preciso não esquecer que após a redação da tese, em 2004, houve uma grande ampliação do crédito sem garantias e muito mais pessoas passaram a ter acesso a cartões de crédito. No entanto, isto ainda não ocorria no período destas entrevistas. 
como se conta a tropa na hora da chamada.” (1997, p. 12). Ou seja, não se trata de escolher critérios "objetivos" que possibilitem a quantificação de cada classe social, já que estas são compostas por relações econômicas e de dominação e não por indivíduos. Após criticar as distinções entre trabalho manual e intelectual, trabalho que produz mais valia e que não a produz, o autor conclui que as classes médias "São doravante compostas de produtores diretos inseridos em relações de produção capitalistas que tendem a predominar sobre as outras (artesanais ou 'liberais').” (ALBUQUERQUE, 1997, p. 30, grifo do autor) Segundo esta definição todos os meus entrevistados encontram-se na classe média, mas cabe perguntar se ainda haveria alguém - exceto os detentores de capital e terras - que poderia ocupar alguma outra posição na estrutura social. Já Araújo (1977) aponta para a importância das diferenças internas às camadas médias, especialmente entre as assalariadas e as não assalariadas, tanto pelas suas condições econômicas quanto pelas suas "posições subjetivas” e políticas. Dessa maneira, alargam-se as relações que devem ser levadas em conta, mas estas continuam não muito específicas: o que, exatamente, contaria como "posições subjetivas"? Sem entrar agora na discussão acerca da divisão subjetivo/objetivo, é possível, desde já, dizer que não basta assinalar posições na esfera da produção econômica para delimitar as classes sociais.

O objetivo desta seção é justamente procurar uma forma de refinar o conceito de classe de modo que possa ultrapassar a formulação simplista das posições na esfera da produção econômica, porém, sem precisar recorrer aos aspectos "subjetivos" como algo exterior a elas e que lhes seja "acrescentado" por uma superposição simbólica. Para tanto, é frutífero colocar em diálogo as proposições de Max Weber acerca da estratificação social - que envolve tanto classes como grupos de status - e as de Bourdieu sobre estilos de vida. A intenção não é fazer aqui uma exegese do conceito de classe, tampouco uma revisão bibliográfica do tema, mas apenas buscar uma forma de aprofundar os níveis da análise. 
As camadas médias contemporâneas parecem ser especialmente problemáticas para abordagens tradicionais sobre classes uma vez que apresentam grande heterogeneidade no que diz respeito à inserção no campo da produção econômica, aos níveis de escolaridade, aos modos de vida e posições políticas (ARAÚJO, 1977) e mais ainda quando se procura analisar a formação de identidades. Muitas vezes abandona-se o conceito de classe pelo de camadas médias delimitadas pelo estilo de vida ${ }^{40}$

Neste trabalho também recorro a este conceito, seguindo a perspectiva de Bourdieu, para quem um estilo de vida é a expressão da força integradora do habitus e de sua capacidade de aplicação a distintos campos da prática. (BOURDIEU, 2003; MCNAY, 1999) Desse modo, não se trata de expor uma listagem daquilo que os entrevistados consomem no vestuário, lazer, artes e outros produtos, mas de procurar compreender quais eixos são relevantes para a construção dos julgamentos e percepções que os fazem sentir que certas práticas, atitudes e também produtos "combinam" com eles e os distinguem dos outros, o que será discutido mais adiante. Procurar construir a análise a partir dessa perspectiva é relevante, sobretudo quando se trata de uma classe de difícil delimitação e que leva diversos autores a procurar refinar suas elaborações conceituais.

Figueiredo (2003), ao fazer a crítica de algumas vertentes teóricas, mostra como a distinção entre trabalho manual e não manual este último definindo o que seria classe média -, ainda que útil para a análise quantitativa, encobre as diferenças de renda e escolaridade que perpassam esta categoria e que são extremamente significativas para os modos de vidas das pessoas que aí seriam enquadradas. Já O’Dougherty (1998) salienta a importância do consumo nas análises sobre formação de uma identidade de classe média, pois se trata de uma esfera que permite tanto a criação de distinções como a diluição de diferenças, mas, ao mesmo tempo, a autora afirma que o consumo como fator identitário não é fenômeno exclusivo dessa

40 Ver, por exemplo, Velho $(1981,1989)$ 
classe $^{41}$ e que a "educação" emerge como outro elemento relevante, como se pode depreender das próprias citações de seus entrevistados que se distinguem de "uma outra classe média" (ascendente, formada por profissionais "não tão qualificados") por privilegiarem a "cultura" e a educação formal. ${ }^{42}$

Entre categorias que se desdobram e critérios que se conjugam, resta o problema de definir a delimitação das classes sociais, principalmente tendo-se em conta a afirmação de Bourdieu (2001, p. 26-27, grifo do autor) de que:

As classes sociais não existem [...]. O que existe é um espaço social, um espaço de diferenças, no qual as classes existem de algum modo em estado virtual, não como um dado, mas como algo que se trata de fazer.

Se for algo que é preciso fazer no âmbito da prática política não cabe discutir aqui, mas sim o fato de que é algo que se trata de fazer sociologicamente, o que significa dizer que a classe média é uma categoria que se constrói para iluminar determinadas relações que, por sua vez, foram eleitas segundo os interesses da pesquisa em questão. (WEBER, 2006) Estes, no presente caso, consistem em procurar distinguir um determinado grupo de adeptos do candomblé do ponto de vista de sua posição social e compreender, de alguns ângulos privilegiados, as implicações disso para o pertencimento e interpretação

${ }^{41}$ A esse respeito ver também Sansone (2001) que analisa as configurações de diferentes identidades entre jovens da favela do Cantagalo, no Rio de Janeiro, justamente em torno do consumo e as compara com semelhantes distinções entre jovens pobres e negros de Salvador. Análises desse tipo problematizam a afirmação de Bourdieu (1999, p. 24) de que as camadas mais desfavorecidas economicamente não entram no "jogo da divulgação e da distinção" e, portanto, participam apenas como "refugo" de um jogo cultural que, objetivamente, se dirige a elas, quer dizer, se destina a demarcar o seu lugar.

42 Como ela mesma reconhece, isto pode ser devido ao fato de que sua amostra foi selecionada a partir de escolas particulares onde estudavam os filhos de seus entrevistados, mas, ao que tudo indica, sua amostra também se limitava a profissionais de nível universitário e não deixa de chamar a atenção o fato de que é exatamente a "educação" ou a "cultura" o que "distingue" também os meus entrevistados dos adeptos mais pobres dos terreiros, como veremos mais adiante. 
desta religião em particular. Assim, denominar os participantes dessa pesquisa de "classe média" não significa que as observações aqui feitas possam ser generalizadas para toda "a classe média", pois eles não são seus "representantes", mas apenas pessoas que, com relação à esfera econômica - com as ressalvas que veremos logo a seguir -, se encontram em certa posição. Portanto, o que interessa saber para definir a posição social das pessoas pesquisadas?

É importante ter em mente que os entrevistados foram selecionados, como foi mencionado acima, pelo grau de escolaridade superior completo, pelo exercício de uma profissão que exige tal título e pela trajetória religiosa. Assim, de início, eu não falava em classe média, mas em profissionais de nível superior, uma "classe" em sentido weberiano:

Podemos falar de uma 'classe' quando: 1) certo número de pessoas tem em comum um componente causal específico em suas oportunidades de vida, e na medida em que 2) esse componente é representado exclusivamente pelos interesses econômicos da posse de bens e oportunidades de renda, e 3) é representado sob as condições de mercado de produtos ou mercado de trabalho. [Esses pontos referem-se à 'situação de classe' [...] A palavra 'classe' refere-se a qualquer grupo de pessoas que se encontrem na mesma situação de classe]. (WEBER, 1974a, p. 212)

Segundo esta definição, uma escolarização específica que assegura uma ocupação, e consequente possibilidade de renda, monopolizada por detentores de títulos seria um critério válido para a definição de uma classe, embora, nesse caso, não pudéssemos falar de uma classe média propriamente dita (o que exige a explicitação de suas relações com as demais classes) e sim de uma classe de detentores de prerrogativas no mercado de trabalho, e para o autor é exatamente a existência de uma situação de mercado o que possibilita o uso da noção de classe. O problema, porém, é que o "componente causal" no caso da escolaridade universitária não é "representado exclusivamente pelos interesses econômicos", mas também confe- 
re status a seus detentores, no sentido de uma "estima social", de uma "honraria" que delimita o círculo social ao qual um indivíduo pode pretender pertencer, as relações sociais - isto é, aquelas não vinculadas a interesses econômicos - que normalmente estabelece e, em geral, até mesmo suas possibilidades de casamento e relações afetivas. A estratificação por grupos de status contrasta com a situação de classe por não ser determinada em função do mercado - que, por seu turno, não deveria levar em conta questões de prestígio nem exclusivamente pela posse. No terreiro, portanto, há pessoas de diferentes classes e grupos de status que mantêm relações sociais e veremos como inúmeros conflitos surgem dessa situação.

Segundo Bourdieu, Weber oporia classes a grupos de status como "dois tipos de unidades reais" que manteriam relações variáveis de predominância conforme o grau de autonomização da esfera econômica e:

Para restituir às análises weberianas toda a sua força e alcance, antes é preciso reconhecer que os grupos de status e as classes constituem unidades nominais que podem restituir a realidade de modo mais ou menos completo segundo o tipo de sociedade, mas que são sempre o resultado da opção de acentuar o aspecto econômico ou o aspecto simbólico, aspectos que sempre coexistem na própria realidade (em proporções diferentes conforme as sociedades e as classes sociais de uma mesma sociedade), uma vez que as distinções simbólicas são sempre secundárias em relação às diferenças econômicas que as primeiras exprimem, transfigurando-as. (WEBER apud BORDIEU, 1999a, p. 14-15, grifo do autor)

A questão de saber se Weber considerava tais formas de estratificação como "unidades reais" ou "nominais" só pode ser resolvida por um trabalho de especialista, o que não é o meu caso. De toda forma, vale à pena remeter o leitor às proposições metodológicas deste autor que sempre enfatizou o aspecto seletivo e limitado do conhecimento sociológico frente à realidade da vida. (WEBER, 2006) Suas formulações são concordantes com a afirmação de que se trata de um 
"acento" cujo objetivo é a compreensão de relações causais. Antes, parece-me que para Weber (1974a) classes e grupos de status não são critérios excludentes de estratificação social, mas, ao contrário, são conceitos que permitem analisar como em sociedades concretas se articulam essas duas bases nas distinções entre seus membros. Por exemplo, a propriedade tende, em função da estabilização da distribuição do poder econômico, a ser reconhecida como "qualificação estamental", ao passo que demonstrar o pertencimento a certos círculos de "estima" mais elevada pode representar melhores oportunidades no mercado de trabalho.

A sociedade de hoje está estratificada em classes e em grau especialmente acentuado em classes de renda. Mas no prestígio estamental especial das camadas 'educadas', nossa sociedade encerra elementos muito concretos de estratificação estamental. Externamente, esse fator é, muito claramente, representado pelos monopólios econômicos e as oportunidades sociais preferenciais dos detentores de diplomas. (WEBER, 1974b, p. 346)

A proposta weberiana é justamente que tais relações de sentido podem ser exploradas e compreendidas sociologicamente, pois não derivam, necessariamente, de uma única esfera da atividade social. Deste ponto de vista, as pessoas aqui pesquisadas constituem uma classe de portadores de diplomas que favorecem a obtenção de uma renda (relativamente) contínua e estável e a posse de bens não tão escassos - como residências e automóveis - devido ao monopólio de posições no mercado de trabalho, mas não chegam a favorecer a posse de meios de produção. Ao mesmo tempo, esses títulos lhes conferem um certo prestígio que é muitas vezes responsável pela perseguição da educação universitária já que, como vimos com Agier e Castro (1995) e Guimarães (1995), nem sempre sua renda é de fato superior àquela obtida por profissionais de nível médio, principalmente quando estes são empreendedores. Esta seria, então, uma classe intermediária tanto pelas oportunidades de renda e posse de bens quanto pelo grau de prestígio alcançado. 
Também do ponto de vista de Bourdieu poderíamos chamá-la de classe média (urbana), pois pela sua posição de classe distinguemse tanto dos detentores de capitais e meios de produção quanto daqueles que devem vender sua força de trabalho em outras condições, sem os "privilégios do monopólio por título" quanto, ainda, da classe média de cidades pequenas, inseridas diferentemente na estrutura social. Por sua situação de classe, essas pessoas mantêm uma relação com o trabalho e com o meio social metropolitano onde vivem que os distingue de outros grupos, como os "pobres" da cidade, por exemplo. (BOURDIEU, 1999a, p. 4) Pode-se dizer que são pessoas cujo capital cultural tem maior peso relativo do que o capital econômico e cuja origem já foi nas camadas médias, embora urbanas para alguns e para outros, como Irene, de pequenas cidades do interior. No caso das pessoas com mais de 45 anos, apenas o pai de Antônia, familiares de Ernesto e um tio materno (importantíssimo, como veremos) de Marta tinham profissões de nível superior. Isto permitiu que os entrevistados fizessem comparações com o seu tempo de infância, quando um funcionário de nível médio, como o pai de Hortência, podia manter oito filhos, "comendo, dando escola, entendeu?", dos quais apenas um não tem formação universitária. Para os mais jovens, a comparação é com as facilidades e a fartura do tempo na casa dos pais. Se lembramos que eles foram crianças na década de 1980, quando a Bahia ainda não sofria os efeitos da recessão nacional, como vimos acima, podemos imaginar que o passado a que tanto os mais jovens quanto os mais velhos se referem era, de fato, mais seguro financeiramente. Assim, esta é uma classe média que, no geral, tem capital escolar mais elevado do que seus pais, mas encontra-se estagnada financeiramente ou em ligeiro declínio (exceto João Alfredo, que teve grande ascensão), como de resto toda classe média brasileira após o "milagre econômico", o que deve contribuir para uma valorização ainda maior da educação e da profissão. ${ }^{43}$

43 Mais uma vez, é preciso lembrar que este texto foi redigido em 2004, portanto antes da retomada do crescimento econômico do país. Contudo, a recente expansão do ensino superior público não parece ter afetado negativamente o prestígio de seus títulos. 
Segundo Jenkins (2000) o que acabo de apresentar constitui uma categorização, ou seja, uma definição externa de uma "categoria de pessoas”. Entretanto, devido à interdependência profunda entre categorização e identificação de grupo - a definição internamente orientada, o "quem somos?" - é importante verificar se a categorização que apresentei encontra alguma correspondência no "momento internamente orientado" dos processos sociais de identificação. Argumentei a favor da importância da formação escolar, assim sendo faz-se necessário investigar um pouco mais no que ela consiste, se e como pode operar como elemento de identificação e quais as consequências disso para os indivíduos pesquisados. É importante ressaltar que não se trata de uma identidade de classe, mas de procurar por elementos distintivos que sejam operantes nas práticas cotidianas dos indivíduos.

No presente caso, o que constitui um grupo de status é justamente o aceso a esta educação universitária que lhes garante certos privilégios, o que é diferente de uma situação na qual há uma educação especial para membros de um determinado grupo de status. É a própria educação que confere prestígio a indivíduos que mantêm relações tão difusas e vagas que dificilmente poderíamos considerá-los um grupo para além do critério da educação formal. Por que a educação universitária é assim avaliada? De que maneira ela pode conferir certas predisposições comuns a pessoas de origens familiares diversas? Apesar de uma ambiguidade presente nas formulações de Bourdieu (2003), que a tornam alvo de críticas por supostas reduções economicistas, seus conceitos conservam potencial heurístico para iluminar as relações entre agentes divididos em classes (e estas podem ser os sexos, os grupos de idade e não somente posições na estrutura ocupacional) e destes com o mundo social constituído por seus atos. O conceito de habitus é especialmente adequado para análises de situações de classe se mantivermos em mente seu caráter relacional: os esquemas do habitus formam um conjunto de predisposições incorporadas que contrastam com outros conjuntos equivalentes, pertencentes a outras 
classes de agentes. A escolarização, nas sociedades contemporâneas, recebeu destaque por parte do autor, pois:

Enquanto 'força formadora de hábitos', a escola propicia aos que se encontram direta ou indiretamente submetidos à sua influência, não tanto esquemas de pensamento particulares e particularizados, mas uma disposição geral, geradora de esquemas particulares capazes de serem aplicados em campos diferentes do pensamento e da ação, aos quais pode-se dar o nome de habitus cultivado. (BOURDIEU, 1999b, p. 111, grifo do autor)

Bourdieu (2003) chama a atenção para o fato de que os esquemas de pensamento, julgamento e classificação são estruturados nas relações entre diferentes grupos de agentes, e ao mesmo tempo estruturam as relações práticas, cotidianas, mantidas entre eles - e com o que é considerado propriedade de cada grupo - constituindo estilos de vida distintivos. Enfatiza também que tais esquemas são incorporados (embodied), constituídos no e pelo corpo, orientando não apenas ideias, mas gestos, gostos e aquilo que é tido como natural. Esta construção conceitual constitui, portanto, um esforço para escapar à dicotomização da prática entre o concreto e as representações, ou entre o objetivo e o subjetivo, explicitando as relações estruturais entre eles. Estilo de vida é uma noção que procura realçar o caráter sistemático de uma série de práticas referentes a campos diversos - como vestuário, alimentação, lazer, produção econômica, família - e que acabam por exercer uma função distintiva exatamente por se encontrarem classificadas com relação aos agentes que as efetuam. (BOURDIEU, 1999a, 2003)

Dessa forma, como já foi destacado, um estilo de vida é expressão da capacidade do habitus para aplicar uma matriz geradora de avaliações e percepções aos campos mais diversos, das relações em família ao ambiente de trabalho. Um estilo de vida não é descrito por uma coleção de "gostos" pessoais, mas pelos eixos que unificam as práticas mais distintas de modo que elas pareçam "pertencer" ao 
agente. Diferentemente do que diz Amaral, um estilo de vida não atua sobre aquilo que mais se distancia das necessidades básicas do ser humano, “[...] aquelas que determinam minimamente a sobrevivência dos homens: comida, abrigo, vestuário, etc." (AMARAL, 2002, p. 21, grifo do autor) Antes, atua sobre elas, fazendo tanto da "necessidade virtude", quanto da "virtude necessidade" e naturalizando o que foi socialmente construído e posicionado. O conceito de habitus permite desnaturalizar as práticas, até mesmo aquelas que parecem ser estritamente de ordem fisiológica (como o nojo), situando-as em diferentes posições socialmente delimitadas. Sua força integradora transforma-as num conjunto implícito, num estilo de vida.

Um exemplo pode ser encontrado na fala de Marta na abertura dessa seção. Vemos como ter acesso a planos de saúde é simplesmente "natural". Ela também parece pressupor que as pessoas dispõem de cartões de crédito - embora estes, de fato, sejam extremamente populares hoje em dia - e cheque especial. Para ela, isto não constitui uma distinção de classe. Tal como para os outros entrevistados, a profissão é um elemento marcante entre suas atividades, projetos e identidade. Marta foi escolhida para ilustrar este ponto porque apresenta algumas idiossincrasias interessantes, que permitem classificá-la como classe média “alternativa”. Ela é uma jornalista negra, de 47 anos, alinhada com movimentos negros, cuja atual ocupação tem relação com isto e ela tem contatos com políticos profissionais que militam por esta causa, mas Marta mantém no dia a dia um discurso “suave” acerca de sua posição de cor. Ela não reproduz o estereótipo da militante "raivosa". Seu modo de se vestir pode ser chamado de “casual alternativo chic", isto é, ela usa muitos tecidos naturais, cores claras, batas e saias longas, sem parecer uma hippie extemporânea. Marta não tem cabelos crespos - são quase lisos, na verdade - e os usa um pouco abaixo dos ombros, brincando com mechas coloridas, principalmente vermelhas, sobre o preto natural. Gosta de comida vegetariana e realizamos nossa entrevista num restaurante 
natural. Naquela época ela estava experimentando tratamentos fitoterápicos, mas desde criança usou homeopatia, resultado da ligação de sua mãe com um centro espírita no Sul, que ainda mantinha a antiga prática de aviar receitas homeopáticas, há muito abandonada em outros locais. A lista poderia prosseguir infinitamente e ainda assim não comporia o estilo de vida de Marta, embora possa dar uma ideia de qual seja. A questão é tentar manter todos estes detalhes concretos em relação com as posições que ocupam socialmente e com as avaliações de Marta. Evidentemente, trata-se de uma tarefa de grandes proporções, irrealizável neste momento.

Assim, mesmo após a realização de várias das entrevistas não tenho condições de definir um estilo de vida próprio dessa classe média aqui focalizada, pois me falta exatamente a percepção que outros grupos têm de suas práticas e propriedades, o que constituiria uma abordagem propriamente relacional. Tampouco posso dizer que se trata de um estilo de vida marcado pelo candomblé, como sugere Amaral (2002, p. 111). Embora concorde que a religião possa oferecer elementos importantes à delimitação de um estilo de vida, a partir do que venho expondo aqui, somente posso afirmar que o candomblé pode participar de alguns estilos distintos entre si, pois não é correto concluir que os membros do terreiro partilhem uma única matriz de avaliação e percepção, mas, contrariamente, que se distinguem entre si. Entre os entrevistados, os estilos de vestuário e cabelos estão muito mais para o "comportado casual" (isto é, que não apresenta qualquer destaque especial), com alguns toques "alternativos", por exemplo, ter os cabelos pintados de vermelho, ao invés do loiro dominante entre "patricinhas" e jovens da periferia. É interessante notar também que são poucas as referências ao "afro", mesmo no caso das pessoas negras que mantêm contato com movimentos negros, Marta e Irene, isto é, elas valorizam elementos da estética "negra" sem seguir o estereótipo exagerado das batas, tranças e colares "africanos" usados simultaneamente. Entre os membros do Torrundê, em geral, o cabelo trançado é o único elemento "afro" comumente observado. 
Mesmo assim é possível perceber algumas recorrências que diziam respeito, sobretudo, à visão da profissão, da religião e da família, mas também do lazer e da "cultura", fazendo da "virtude necessidade" ao afirmar exatamente a naturalidade de certas escolhas. Elas serão retomadas mais adiante, após a busca pelo eixo que permita construir alguma relação entre essas práticas e as avaliações de posição social.

\section{RENDA E EDUCAÇÃO: O QUE FAZ A DIFERENÇA?}

Do ponto de vista da renda individual mensal, o grupo entrevistado é bastante heterogêneo, indo de aproximadamente $\mathrm{R} \$ 400,00$ à cerca de R\$ 10.000,00. ${ }^{44}$ Entretanto, é preciso levar em consideração que nem todas as pessoas encontravam-se na mesma situação familiar nem na mesma faixa etária na época da entrevista. A personagem que ganhava menos era bastante jovem e residia com os pais. Sua renda familiar era bem mais elevada do que o auferido pessoalmente. O restante dos pesquisados tinha rendimentos individuais em torno de $\mathrm{R} \$ 1.500,00$, ou um pouco mais. Os médicos, como é de se imaginar, apresentavam renda muito mais elevada. Outro elemento a ser considerado é que estas entrevistas se realizaram ao longo de quatro anos, o que relativiza os números absolutos. De uma forma ou de outra, estas são pessoas cujo rendimento do trabalho encontra-se acima da média de Salvador, que em junho de 2004 estava em R\$707,00, e muito acima da mediana. No entanto, como já foi enfatizado várias vezes, a renda somente não responde por outras distinções como o prestígio da carreira de nível superior.

44 Estas informações não foram integradas aos perfis expostos por serem consideradas "delicadas" para muitas pessoas e devido ao fato de que estas são, na verdade, facilmente identificáveis por seus grupos religiosos, o que poderia expô-las a inconvenientes. Da mesma maneira, qualquer citação que possa causar embaraço a seu autor sofreu cortes de quaisquer identificadores. É preciso lembrar ainda que estes valores devem ter o ano de 2002 como referência. 
Assim, ao tratar deste tema é importante considerar a idade das pessoas e sua posição na carreira profissional: jovens com pouca experiência em geral ganham bem menos que pessoas mais velhas, que já alcançaram outros patamares, ao menos nas profissões de nível universitário. Como foi apenas indicado acima, essa é uma noção importante para a maneira como os próprios entrevistados veem suas profissões: como uma carreira que foi sendo (ou será) construída, galgando-se degraus mais elevados através de títulos e experiências "legítimos". Aqueles que têm menos de 50 anos de idade revelam essa concepção em seus sonhos e projetos profissionais. Procuram cursos de especialização ou mestrados e dedicam parte de suas horas vagas a atividades correlacionadas ao trabalho. Mesmo para os mais velhos não há uma ideia de que tais percursos já se cumpriram e o que surge é uma "dificuldade" em se aposentar, mesmo quando afirmam desejá-lo e não o poder fazer devido às "necessidades básicas" que têm que suprir, ou porque, como diz pai Dary, sua profissão e sua religião são sua "cachaça”. Para Ernesto, que afirma desejar se aposentar para "viver de sandálias na praia", a participação em congressos e eventos do gênero deve-se a sua preocupação com a atual situação da saúde mental no país:

Mas eu também não acho que isso é alguma coisa que eu vou realizar individualmente, então eu procuro estar provocando algumas discussões, participando de alguns niveis de reflexão, dando opinião, me metendo onde não sou chamado. [Luciana - Por que? ] Eu tô vivo!

As profissões exercidas tampouco são vistas como simples meio de obter renda. Equede Hortência, que apesar de aposentada "teve" que continuar trabalhando, vê essa situação como extremamente negativa:

A gente tá vivendo num país tão ruim que hoje a gente vê a profissão como meio de vida, entendeu?

Tal percepção vem a corroborar a interpretação de Guimarães, Agier e Castro (1995) de que profissões universitárias possuem uma 
valorização que se vincula muito mais ao tipo de conhecimento exigido e à sua própria posição social do que aos rendimentos obtidos. Desse modo, podemos inferir que se trata de uma camada para quem o trabalho ainda é um componente central de suas identidades, ao contrário do que é apontado por Sansone (2001) para os jovens da favela do Cantagalo - com sua marcada preocupação com o consumo e a aparência para demarcar estilos distintos - e por Agier e Guimarães (1995) para os trabalhadores de origem pobre e sem títulos escolares de Salvador, cujas identidades são construídas por oposição a um entorno de pobreza ainda maior.

É interessante, neste ponto, fazer uma breve observação sobre a autoclassificação de tais pessoas. Quase todas se definiram como classe média ou média baixa, à exceção de duas, que se definiram como classe baixa, ambas explicando que, no Brasil de hoje, "não há mais classe média, mas apenas ricos e pobres”. McCallum, que também pediu uma autoclassificação das pessoas que entrevistou na Baixa de Camarujipe, uma área bastante pobre na periferia de Salvador, encontrou respostas semelhantes para uma situação muito diferente:

Estas pessoas normalmente ganham um salário mínimo ou menos (cerca de US\$110,00 por mês em 1996), sofrem altas taxas de sub ou desemprego, vivem principalmente em terrenos legalmente irregulares em casas auto-construídas (ou em conjuntos de "baixa renda"), estudam menos de quatro anos na escola e/ou são iletradas e, geralmente, mestiças ou negras. (MCCALLUM, 1996, p. 210)

Ainda assim, frequentemente se identificavam como classe media, ${ }^{45}$ segundo a autora (MCCALLUM, 1996, p. 214), distinguindo-se dos "pobres" que seriam "os que dormem nas ruas". Esta pequena curiosidade reforça a necessidade de se procurar por aquilo que as próprias pessoas entrevistadas percebem como o que as distingue de outras classes e, evidentemente, mostra a inviabilidade de se usar a

45 Não é possível deixar de observar, contudo, que a situação relatada por McCallum é bastante atípica e não tenho notícias de ter sido observada por outros pesquisadores. 
autoclassificação com qualquer outro intuito. Também é interessante notar que, como as pessoas entrevistadas me foram apresentadas por outras que sabiam do meu interesse pela "classe média”, elas são consideradas como tal por quem as indicou. Normalmente isto representou uma sobreposição entre as indicações para entrevista e as redes de amizade mais íntimas.

Aqui a educação é um elemento fundamental que ganha força ainda maior quando comparada com a "falta de educação" de pessoas mais pobres. As falas a seguir, expressas por diferentes entrevistados, dão uma ideia de como as interações com elas eram percebidas no início da vida religiosa (mesmo que muitas vezes essas opiniões tenham se modificado com o passar dos anos).

Pergunta - Foi muito difícil começar a aprender [a parte ritual]?

Resposta - Sim, porque eu vinha, eu venho de uma situação socioeconômica, 'cultural' diferente das pessoas que vivem ali. Primeiro vem essa situação, tanto na parte da cultura religiosa, quanto na parte de, cultural 'mesmo' e social. [ênfase na entonação]

Pergunta - E você teve dificuldades nos relacionamentos?

Resposta - Tive. Primeiro aprender a lidar com o jeito africano de deixar as emoções à mostra, porque no meio intelectual, tudo é muito cortês. [...] Lá eu não era uma [profissional X]. Lá eu era uma 'abiã', como outra qualquer que não tenha nem o curso primário. Isso foi uma grande aprendizagem na minha vida. Lá eu tinha uma hierarquia rígida, pra cumprir. [ênfase na entonação]

Pergunta - Mas não foi um pouco difícil de aceitar que um, que uma divindade podia vir e tomar o seu corpo?

Resposta - A manifestação em si, pra mim, ela já não era espantosa, já não era algo tão anormal.

$P-A h$, certo.

$R$ - $O$ difícil foi a minha adaptação a todo um processo de convívio social, que é tipo, você trabalhar dentro [do lugar 
$\mathrm{X}]$ e ter que conviver com a plebe, o pessoal mesmo humilde, onde você, as pessoas não sabem se expressar, enfim... e a casa onde eu fui iniciado, o início dela, eram pessoas altamente simples. Semianalfabetas. Então pra você adaptar nesse novo nível... foi muito difícil. O meu convívio, minha dificuldade maior, eu diria que foi social.

Pergunta -E você acha que tem alguma resistência porque você é novinho, você é jovem?

Resposta - Eu sou jovem, eu sou de fora. Eu não moro lá, a maior parte das pessoas é de lá, entendeu? Assim, o fato de eu ser universitário mexe com a cabeça das pessoas, embora eu não comente absolutamente nada disso lá. Assim, essa discrepância social infelizmente mexe com a cabeça das pessoas.

Pergunta - Tem alguma coisa que te incomoda, assim, na relação, não com uma pessoa específica, mas mais no geral, com o grupo?

Resposta - [O terreiro] é uma cidade, né?, Uma polis, aquelas histórias antigas, porque tem... tem todas as pessoas que administram aquela cidade, né?, As relações, por aí vai, e por ela ser assim, muito pequena, você convive mais junto, né?, Com pessoas, com pontos de vista diferente, com nivel de escolaridade diferente, com projetos de vida muito diferentes, muito, muito, muito, e tem momentos assim que é choque, né?

Mas “educação" não significa somente escolaridade, embora esta possa ter sido citada várias vezes:

Pergunta - E como foi que você conheceu o candomblé?

Resposta - [Conta o porquê decidiu ir a uma festa] Quando cheguei, cheguei mais cedo. A dona do terreiro, dona $[\mathrm{X}]$ tinha descido pro barracão e as moças, as filhas de santo ainda não estavam prontas. E ela deu logo um show, né? Ela abriu a boca 'vocês querem me sacanear', desculpe os palavrões porque... 'vocês querem me sacanear, suas puta desgraçada do mangue das cachorras?' Eu achei aquilo o fim da picada. Eu digo 'Deus me livre de nunca ser de can- 
domblé, mas veja só se eu vô aceitar uma coisa dessa, de uma pessoa ignorante, meio metro de mulher pra me xingar desse jeito! Mas nunca na vida, não tem Deus nem o diabo que me faça entrar no candomblé.

Como podemos perceber, a questão da "educação" alcança também o âmbito da moralidade:

Em vez de se concentrar no orixá, de ver que ali é local religioso, de... em vez de estar buscando a energia, o crescimento espiritual, não, tá ali, é, na roda, mas tá rebolando porque tem uma pessoa gatinha olhando, entendeu? Quer passar na frente de todo o mundo por causa disso, quer aparecer mais, quer dançar mais, quer bailar mais, acontece isso também, me deixa triste. É falta de seriedade.

Queixas quanto ao comportamento dos outros adeptos, para quem o terreiro pode ser um espaço de destaque individual e interações sociais mais amplas, são muito frequentes. Na roça, várias vezes ouvi comentários próximos ao citado acima. A grande presença de homossexuais também é comentada, mas é importante notar que as críticas se referem apenas aos "fechativos", isto é, àqueles muito escandalosos. Os demais são aceitos sem problemas, inclusive alguns dos entrevistados o são.

Já o comentário como o que segue, foi único em seu teor, mas ainda assim expressa uma forma de percepção das distinções dentro do grupo culto.

Tem essas desigualdades todas, né? E no que se refere ao culto, as pessoas ficam todas iguais, então cê [...] e mais, elas se agregam conforme a categoria familiar, as pessoas são irmãs, são pais, são filhos, né? Então, é, isso gera algum nivel de interesse nos relacionamentos. Então as pessoas que têm menos posse, com alguma frequência, é, demandam às pessoas que têm maior disponibilidade financeira, ou material, algum tipo de coisa, então isso interfere muito na relação das pessoas, né? 
Em contraste com estes choques muito específicos entre "modos" de pessoas de contextos socioeconômicos mais "baixos", as comparações com o que consistiria em ser de uma camada mais ele$\operatorname{vada}^{46}$ são marcadamente ambíguas e abstratas. Em geral, quando perguntadas sobre o que lhes falta para ser de classe média alta ou classe alta, as pessoas se referiam a ter mais do que elas já têm, poder fazer mais do que elas já fazem e poder "relaxar" quanto às despesas mensais, ou como disse Ana: "ter para este mês e mais para o mês que vem e o outro". É curioso observar que nenhuma delas se referiu, por exemplo, à possibilidade de viver sem trabalhar, caso fossem de classe superior. Parece-me que o seu convívio no terreiro possibilitou experiências diretas com pessoas de camadas inferiores e, com isso, as narrativas "rudes" daquilo pelo que passaram, ao passo que as referências às camadas mais altas se baseiam em preconceitos e hipóteses pouco questionadas. Pode-se argumentar que a mera falta de contato direto com pessoas das camadas superiores levaria a formulações vagas. Por outro lado, pode-se também supor que estas formulações não demarcam uma clara linha de distinção com estas últimas. Grosso modo, podemos dizer que essas pessoas de classe média se distinguem da classe baixa pela "educação" e "não se distinguem" da classe alta - quer dizer, não refletem sobre esta distinção - mesmo no caso de Ernesto, cuja história pessoal inclui o trânsito entre tais pessoas. Para ele, o que demarcou sua posição diferenciada frente aos seus colegas de colégio e faculdade de elite sempre foi sua cor. Irene também viveu algo semelhante por ser filha de uma família negra, porém importante, em uma cidade do interior. Apesar de ser filha de um dos principais organizadores dos eventos religiosos do local, ela nunca pode ser o "anjinho" das procissões, pois naquele tempo, estes só poderiam ser crianças brancas.

Quanto às profissões exercidas, todos os entrevistados afirmaram tê-las escolhido por "gosto", mesmo quando levaram em conta outros

\footnotetext{
46 Agradeço à Ângela Figueiredo pela sugestão, nos idos de 1999, de perguntar nas entrevistas o que demarcaria o pertencimento a uma camada mais elevada. A estratégia revelou-se extremamente útil.
} 
fatores, como o mercado de trabalho ou a dificuldade de certos vestibulares, como Ana, que não passou no vestibular para Psicologia, então escolheu outra área "pelo curso": viu que Administração tinha um bom mercado e que Recursos Humanos lhe permitiria "lidar com gente" que é o que ela sempre gostou. Ou como Pedro, quando fala sobre a possibilidade de escolher outra profissão: "O máximo que eu posso vir a pensar é em trabalhar com eventos. Que tá dentro da minha área. Acho que foi dom", disse ele. É interessante, mais uma vez, comparar a ideia de escolha com o ambiente familiar. O único que afirmou que a outra profissão de seus "sonhos" (questionados se pudessem escolher "qualquer coisa mesmo, de fantasia") era uma semiqualificada (caminhoneiro) é exatamente aquele para quem não houve "opção":

Não foi nem propriamente uma escolha, né? A vida foi toda... evoluiu para que eu fosse médico, né? O pai da minha mãe era médico, a minha mãe tinha dois irmãos, ambos eram médicos e existia uma questão familiar forte, né? Eu tinha muito esse modelo na minha frente e sempre disse, desde que eu me lembro, eu sempre dizia que queria ser médico.

Também Marta alega que a escolha de Jornalismo se deu pela influência de um tio materno que exercia a profissão:

E eu era muito apegada a ele, né? Ele participou muito da minha formação, então eu acho que vem um pouco dele essa coisa. [...] Mas eu acho que tem uma coisinha de tradição, sim, nisso, porque era a pessoa que eu me espelhava, né? [Luciana - O que você via ele fazer?] É, isso. Estudando, indo pra escola, sabe, eu achava aquilo tão bonito!

Tal como na entrada no candomblé, não há conflito entre admitir a influência "exterior" (os desígnios do orixá ou o ambiente familiar) e uma ideia de liberdade quanto ao que se faz. Não estaria isto calcado numa "ideologia individualista" que, havendo incorporado elementos de teorias psicanalíticas e psicológicas (VELHO, 1981), apresenta uma noção de indivíduo enquanto agente social, ou seja, aquele que determina seus movimentos no mundo social? A “educação” tão valorizada que se carrega, o gênero, a idade e mesmo a cor aparecem como atri- 
butos pessoais que posicionam - e não como marcadores de uma posição social -, e é preciso levar isto a sério, pois estes atributos não apontam para um mundo social "além" do sujeito, mas apontam para o próprio indivíduo como lugar da ação social. Não se é o representante de tal ou qual "ordem de pessoas”, mas sim uma pessoa única, um entrecruzamento de qualidades e eventos, embora não se ignore as correlações com o contexto mais amplo.

Em suma, podemos dizer que esta é uma concepção na qual o ser humano não se encontra solto num caos de indeterminação, mas também não é um índice de posições ocupadas como agente social. Isso na visão dos entrevistados. Na deste trabalho procuro estabelecer correlações entre suas posições sociais e o exercício de uma religião. Ou, para utilizar os termos de Jenkins (2000), procuro correlacionar a categorização que fiz dessas pessoas - o momento externamente orientado no processo dialético de identificação/categorização, isto é, o que o outro diz sobre nós - com a sua identificação - o momento internamente orientado, ou que eu penso de mim e de nós - através de distinções que, nas entrevistas, ganharam relevância para a diferenciação entre nós e outros..$^{47}$

Isto, porém, não significa considerar a percepção de si mesmo como indivíduo, como uma ideologia, um simbolismo que mascara a realidade aos próprios envolvidos. Ao longo de todo este trabalho procurarei tratar a noção de individualidade e de escolha como uma forma de se engajar no mundo social e testar sua pertinência para a compreensão de como se dá o processo através do qual tais pessoas identificam-se com o candomblé. Como foi dito, é então necessário focalizar as especificidades do candomblé e de suas relações, pois não é apenas a esfera da produção, o âmbito econômico, que é capaz de oferecer elementos de alto valor para se traçar tais definições.

47 O autor deixa muito claro que diferenciação e semelhança são duas faces do mesmo processo, uma só tem sentido quando confrontada com a outra, e, assim, a identificação envolve tanto o nós quanto os outros, mas cada momento do processo põe a ênfase em um aspecto do mesmo. Mais uma vez, pessoalmente ocupo a posição ambígua de pertencer tanto ao outro que categoriza quanto ao grupo que identifico como "nós". 


\title{
Destinos e escolhas: a classe média escolarizada no candomblé
}

\begin{abstract}
Porque a principal mudança, ela é interior, né? A partir da minha mudança interior, a minha mudança de valores, que eu acho que a principal [...] a mudança de condição, financeira e tal, isso é mínimo. Não, cê pode estar muito bem como protestante, como católico, não importa, não é isso. A questão financeira, social, é uma outra história, mas a principal mudança, ela é interior. A forma como você vê a vida, a forma como você busca orientar e conduzir a tua vida, e as pessoas que te buscam. Que tipo de orientação você pode dar, né? (Robson, babalorixá)
\end{abstract}

Nesta fala de pai Robson, podemos identificar duas noções muito comuns em nossa sociedade: a de que todos nós temos uma espécie de "vida interior" e a de que esta vida interior pode ser transformada, ganhar outras “orientações”, mesmo sem mudanças visíveis nas condições sociais da pessoa. Em termos familiares ao senso comum acadêmico, poderíamos dizer que, para pai Robson, podemos sofrer (e até buscar ativamente) modificações subjetivas sem que estas correspondam a mudanças objetivas em nossas vidas e relações. Para muitos ainda, como Giddens (2002), é na capacidade de nos voltar- 
mos reflexivamente para esse aspecto subjetivo que reside a particularidade da construção de identidades na modernidade:

Começamos com a premissa de que ser humano é saber, quase sempre, em termos de uma descrição ou outra, tanto o que se está fazendo como por que se está fazendo. [...] As convenções sociais produzidas e reproduzidas em nossas atividades diárias são refleximamente monitoradas pelo agente como parte do "seguir em frente" nas diversas situações de nossas vidas. A consciência reflexiva nesse sentido é característica de toda ação humana, e é a condição específica daquela reflexividade instituicional maciçamente desenvolvida, [...] como componente intrínseco da modernidade. (GIDDENS, 2002, p. 39)

Uma vez que a questão central deste trabalho é "como pessoas de classe média passam a se identificar com o candomblé”, a proposição de Giddens sobre processos reflexivos na formação de autoidentidades na contemporaneidade desperta interesse. Afinal, como o autor argumenta, as próprias instituições sociais em que agimos, hoje em dia, são marcadas por alto grau de revisão e incorporação reflexivas de suas ações. Poderíamos dizer, em termos weberianos, que a própria noção de modernidade ficou marcada pelo desenvolvimento, cada vez mais acentuado, de racionalizações em variadas esferas de ação (WEBER, 1974c, 2006), incluindo as concepções de identidade e pessoa, apresentando, portanto, fortes afinidades com o desenvolvimento de religiosidades interiorizadas, isto é, centradas na autoinspeção sistemática do próprio comportamento e consciência, muito mais do que em fórmulas mágicas ou rituais. (WEBER, 2004, p. 105-107) Contudo, uma vez que não se deve partir de significações já prontas, seja a ideia de "identidade" ou a de "modernidade", é necessário considerar, ainda que brevemente, como tais noções vieram a se tornar correntes para nós, tanto no meio acadêmico quanto no leigo. Assim, a seguir será apresentada uma tentativa de análise do candomblé como religião em uma sociedade "moderna" - destacando os possíveis "atrativos" que oferece a seus adeptos e, posteriormente, uma interpretação da formação de identidades de 
pessoas de classe média nesse contexto. É evidente que a seleção dos autores escolhidos para sustentar a argumentação já indica filiação a suas ideias, mesmo não sendo uma incorporação de todos os seus aspectos. Portanto, a seguir não será apresentada uma revisão da literatura sobre modernidade ou identidade, mas sim uma apropriação teórica que considero adequada aos objetos desta pesquisa.

Como ponto de partida, gostaria de remeter às análises de Max Weber sobre as inter-relações entre o processo histórico de desenvolvimento da sociedade ocidental moderna e o das religiões nela existentes. Um dos aspectos trabalhados pelo autor, e central nesta discussão, refere-se à importância de certas camadas sociais, no papel de grupo preferencial de adeptos, para a gestação de formas específicas de religiosidade. (WEBER, 1974a, 1974b) A religião deve atender aos interesses - sejam eles "materiais" e/ou "ideais" - de seus fiéis, interesses que estão relacionados ao estilo de vida do grupo social a que pertencem. Assim, nas sucessivas gerações dos membros de uma comunidade religiosa, a religião vai tomando as feições que melhor respondem aos interesses da camada social que mais the fornece participantes. Esta relação, porém, não é unívoca e, segundo o autor, “[...] o tipo de uma religião, uma vez marcado, exerceu habitualmente uma influência de amplas consequências sobre o modo de vida de camadas muito heterogêneas". (WEBER, 1974a, p. 312) Ou seja, se a posição social dos adeptos preferenciais pode marcar profundamente o estilo de uma forma religiosa, esta também pode influenciar a condução da vida em grupos muitos variados. Dessa forma, a própria concepção corrente de "vida interior" reflexivamente monitorada pelo sujeito - acima referida à Giddens - poder ter seu parentesco remetido aos desenvolvimentos do protestantismo dos séculos XVI e XVII, sobretudo às seitas puritanas com sua ênfase na necessidade de condução metódica e racionalizada de todas as ações cotidianas mundanas, em oposição a qualquer possibilidade de salvação por ações exteriores. (WEBER, 2004, p. 105-107) ${ }^{48}$

48 E especialmente. (WEBER, 2004, p. 131-138) 
Contudo, a própria identificação de uma camada social preferencialmente fornecedora dos membros de uma religião particular é uma tarefa bastante complicada, pois se dá de forma retrospectiva, isto é, como historicamente ocorreu em casos particulares, uma vez que não há uma relação necessária nem exclusiva que permitiria a previsão das eleições religiosas pessoais ou coletivas. Em outras palavras, não há nas religiões em si, tampouco nas posições sociais, elementos intrínsecos que determinem umas para camadas superiores e outras para inferiores. O mesmo pode ser afirmado acerca da possibilidade de uma camada social - seja ela urbana, rural, guerreira ou comercial - vir a influenciar de modo decisivo o comportamento econômico de toda uma sociedade num dado momento histórico, mesmo perdendo esta preeminência em outros períodos. (WEBER, 1974b, 1974c, 1991, 1996)

As análises de Roger Bastide sobre a formação do candomblé e suas variações já apresentavam afinidades entre esta religião e particularidades da sociedade brasileira, conjugando uma "[...] sociologia dos contatos de civilizações, tal como se processaram entre nós [e] uma antropologia africana que ele pretende esboçar a partir do exame dos universos africanos aqui existentes”. (PEIXOTO, 2000, p. 95) Ao analisar o sincretismo brasileiro entre catolicismo e religiões africanas, Bastide defende a pertinência de três princípios lógicos: de participação, segundo o qual elementos distintos são pensados como essencialmente aparentados; de corte, que permite a divisão das esferas de ação em "universos" simbólicos apartados; e de correspondência, subjacente às operações de analogia entre elementos de diferentes "universos", sem que estes "participem" conjuntamente de um mesmo nível da realidade. (PEIXOTO, 2000. p. 110) Dessa forma, "participações" ocorreriam entre "universos" de conhecimento/pensamento, mas entre estes e o universo da inserção social ocorreriam analogias, permitindo que os negros brasileiros transitassem entre distintas esferas e, ao mesmo tem- 
po, mantivessem certos traços de suas culturas africanas originais. (PEIXOTO, 2000. p. 112)

Embora a complexa combinação desses princípios permita a aceitação de brancos no universo religioso afro-brasileiro, esta se daria de modo individualizado, enquanto que a produção coletiva dos quadros simbólicos dessas religiões permaneceria negra por excelência. Durante décadas apoiada em análises da "diferença negra", pode-se dizer que, na literatura acadêmica sobre a formação do candomblé como religião, embora com ênfases muito variadas, houve uma identificação com a população mais escura e pobre das nascentes cidades brasileiras, como em Carneiro (1991) e Bastide (1971, 2001), em especial, em certa região:

Como esclarecem os trabalhos de Dantas (1988) e de Birman (1985), a construção de um discurso de 'pureza nagô' produziu um regionalismo que opunha Nordeste e Sudeste em torno do grau de preservação das origens africanas, ficando a última em situação de desvantagem tanto pela menor homogeneidade em termos de influências raciais, quanto pelo predomínio dos grupos 'bantos', cuja cultura e religiosidade não eram tão 'evoluídas' (portanto, mais vulneráveis ao 'incretismo') quanto a dos 'nagôs' que teriam povoado maciçamente o Nordeste. (apud GUIMBELLI, 2003, p. 259)

Em resumo, pode-se dizer que, durante décadas, análises socioantropológicas sobre o candomblé identificaram seus participantes como sendo tipicamente provenientes das camadas menos favorecidas em termos econômicos e educacionais, de pele mais escura, com origens africanas e residentes nas (se não natural das) cidades nordestinas. Contudo, autores como Prandi (1991, 1999) e Oro (1998) observam que, cada vez mais, indivíduos escolarizados de variadas origens religiosas e familiares vêm aderindo ao candomblé em diversas regiões do país. Essa eleição torna-se ainda mais interessante por se tratar de uma religião cuja própria "tradição" afirma sua especificidade em relação ao Ocidente: suas tão aclamadas raízes africanas e seus magníficos aspectos mágicos e rituais. Talvez o número de pes- 
soas de classe média nos terreiros não seja (ainda?) tão expressivo, mas o que chama a atenção é justamente a trajetória que os leva a se vincular a uma religião, normalmente, considerada própria de outro “extrato social”. Como, então, se dá esse processo de identificação religiosa? Que tipo de reelaboração pessoal esses indivíduos efetuam quando se envolvem com esta religião em particular? Tais questões têm ocupado posição marginal nas pesquisas socioantropológicas sobre esta religião afro-brasileira.

\section{CANDOMBLÉ, INTELECTUAIS E CAMADAS MÉDIAS NA LITERATURA ACADÊMICA}

Como dito acima, o candomblé já foi considerado como religião de um grupo social bem definido, composto por pessoas pobres e negras (PRANDI, 1999), ou como continuidade do patrimônio cultural dos africanos escravizados e seus descendentes, destacando-se a persistência da preocupação com o lugar que tais elementos ocupariam na identidade "nacional”, como apontou Birman (1997, p. 79). Mesmo que seja sempre possível uma dúvida quanto a um suposto exclusivismo racial e social dos frequentadores dos terreiros de candomblé (REIS; SILVA, 1989; SANSI, 2003), hoje esta religião é considerada "universal", isto é, aberta a todos, independente de cor ou situação socioeconômica (PRANDI, 1999, p. 93) ou "aberta a conversão de todas as pessoas”. (CAMARGO apud PIERUCCI, 2006, p. 114) Este processo de “universalização" tornou-se nítido principalmente a partir dos "anos 1960", quando na efervescência da contracultura, uma classe média "intelectualizada" passou a valorizar a "autenticidade" nacional como produto digno de atenção e consumo. (PRANDI, 1999, p. 102)

De fato, não é raro encontramos referências, na literatura acadêmica, à presença de indivíduos provenientes de camadas mais favorecidas nos grupos de culto, a começar pelos próprios pesquisadores, que desde fins do século XIX elegeram o candomblé como objeto de estudo. (DANTAS, 1988; SILVA, 1998) Entretanto, é bem 
mais difícil encontrarmos textos que deem alguma atenção analítica a esta participação. Mesmo no caso de se tratar de um pai de santo, sua escolaridade mais elevada do que o comum não parece ter chamado a atenção de Edison Carneiro (1991, p. 40), que se limita a comparar a situação de pobreza dos terreiros, cuja fisionomia não diferia "muito das casas pobres, em geral, da Bahia," com a de um templo em particular:

Segundo a concepção corrente, as mulheres devem dançar descalças sobre chão, nunca sobre soalho. Há alguns anos, Natividade [Neve Branca], pouco antes formado em odontologia, realizou uma inovação na sua casa de Brotas, pondo soalho em todos os compartimentos. Outros candomblés começam a fazer o mesmo. (CARNEIRO, 1991, p. 40, grifo nosso)

Qual a origem social de Natividade, que tipo de clientela e afiliados atraía e que significados pode ter sua "inovação" no piso da casa são questões que não tiveram lugar em um dos textos “clássicos” nos estudos sobre religiões afro-brasileiras. Apenas o encadeamento das frases sugere haver uma conexão de sentido entre a escolaridade do sacerdote e sua atitude, e é corriqueiro encontrarmos apenas breves frases constatando que entre a clientela ou entre os ogãs de um terreiro há pessoas de situação econômica mais favorecida ou mesmo da "elite" econômica e política da região, o que consistiria em uma inegável fonte de prestígio e recursos econômicos para o grupo de culto. (SILVERSTEIN, 1979; DANTAS, 1988; BRAGA, 1999; PRANDI, 1991) Prandi chega mesmo a sugerir que o cargo de ogã foi criado para dar uma posição religiosa a pessoas que poderiam obter benefícios para os terreiros:

No caso do candomblé, este fizera-se cercar desde seus primórdios de pessoas influentes na sociedade: profissionais intelectuais que nutriam pela religião dos negros simpatia e admiração e que mantinham com os terreiros de candomblé e seus dirigentes laços afetivos e de solidariedade. Os candomblés criaram para essas pessoas um cargo hierárquico que representava uma espécie de pai 
protetor, o ogãa, a quem cabia estabelecer uma espécie de ponte entre o terreiro e o mundo branco, protegendo o grupo de culto da perseguição policial, resolvendo problemas burocráticos e políticos, ajudando financeiramente no provimento dos ritos. (PRANDI, 1999, p. 101, grifo do autor)

Em "Mãe de todo o mundo: modos de sobrevivência nas comunidades de candomblé da Bahia”, Silverstein (1979) centrou sua análise justamente na relação de poder desenvolvida entre mães de santo (mulheres, negras e pobres) e homens de classes mais elevadas. Para a autora, a capacidade de atrair homens em posições sociais dominantes para o cargo de ogã seria um componente fundamental do prestígio e da "força" de uma sacerdotisa que, assim, lograria ter mais recursos para atender às necessidades religiosas de seu grupo e mais "poder", tanto social e econômico quanto religioso. Portanto, a presença desses sujeitos - sempre homens que não entram em transe - nos terreiros foi analisada sob a perspectiva das "estratégias" desenvolvidas por essas mulheres para a reprodução e expansão do grupo de culto. Embora seu artigo traga importantes contribuições para a compreensão das relações de poder entre os terreiros e a sociedade abrangente (ou melhor, entre "mães de santo" e "homens", numa sociedade que privilegia as posições masculinas), a perspectiva escolhida não permite que as experiências religiosas desses sujeitos, “estrategicamente seduzidos” pela religião, sejam levadas em conta. Assim, não é possível entrever que relações estes indivíduos estabeleciam com o candomblé, mas apenas o inverso.

Tais posições chocam-se frontalmente com a de Braga (1999), que procura enfatizar tanto as funções "diplomáticas” e "burocráticas" dos ogãs quanto o exercício de atividades propriamente religiosas. Como sustenta o autor, e também Augras (1983), uma boa parte do quadro dos ogãs é recrutada entre parentes e vizinhos, pessoas já conhecidas dos membros da casa e familiarizadas com o universo das religiões afro-brasileiras. Curiosamente, os mesmos textos que con- 
sideram o ogã típico como o "homem em situação social superior" exploram somente as benesses que fluem da posição deste homem para o grupo religioso, sendo o outro o lado da questão quase sempre negligenciado:

Se o candomblé pode ser eventualmente beneficiário de uma ajuda, o ogã está permanentemente protegido do ponto de vista religioso, o que para muitos traduz-se em satisfação e recompensa indescritíveis. (BRAGA, 1999, p. 57)

E o que dizer quando este homem de classe superior não se limita mais a ocupar a posição de ogã e passa a atuar de forma mais variada no grupo de culto? Ou quando não são apenas mulheres pobres, negras ou pouco escolarizadas que estão na roda, como filhas de santo? E sobre as mulheres que exercem as funções rituais mais "racionalizadas”, as equedes, cujas atividades decorrem de seus cargos e são pouquíssimas vezes mencionadas nas pesquisas sobre candomblé?

No célebre trabalho de Dantas (1988) sobre a construção da "pureza nagô", as pessoas de camadas sociais mais favorecidas aparecem, basicamente, de duas formas: como os intelectuais que, voltando-se para o candomblé como objeto científico, imiscuíam-se na disputa interna ao campo religioso por poder e prestígio, acabando por difundir a ideia da superioridade dos cultos de origem nagô; ou então como a clientela mais abastada do terreiro onde a pesquisa foi efetuada, clientela que (apesar de afastada dos cargos da casa), além de recursos financeiros, podia oferecer proteção política à comunidade. No caso em questão, seria realmente difícil que a autora tratasse dessas pessoas de outra forma, uma vez que ela afirma ter sido a estratégia escolhida pela casa estudada a de não ampliar a família de santo para incluir possíveis aliados (DANTAS, 1988, p. 197-234), evidenciando vias diversas daquelas retratadas por Silverstein para o caso baiano. Neste último, a opção foi "estender" a família de santo para abarcar seus “protetores”, que eram "suspensos ogãs” (quer dizer, escolhidos por um orixá para ocupar um cargo no terreiro), criando-se assim um vínculo entre as casas e os senhores eleitos, mesmo que es- 
tes nunca viessem a passar pelos rituais de confirmação. Na situação analisada por Dantas, embora as relações do terreiro com pessoas em posições mais favorecidas sejam mostradas de forma mais nuançada (nem sempre íntima e harmoniosa), elas não constituem exatamente o foco da análise e acabaram por retornar para a marginalidade que vêm ocupando na literatura especializada.

Já Prandi (1991) chega a colocar a questão de quais interesses o candomblé poderia atender para aqueles que dele se aproximam, como fiéis ou como clientes, na grande São Paulo contemporânea. A religião tanto pode ser atraente pelos serviços mágicos que oferece sem exigir vínculo duradouro, quanto pela constituição de seu espaço social e sagrado, ou seja, espaço onde o fiel trafegará pelos diferentes níveis hierárquicos - o que pode ser percebido como uma forma de "ascensão social simbólica" - e onde poderá encontrar novas formas de expressão. (PRANDI, 1999, p. 84-90) No entanto, o autor parece atribuir demasiada ênfase à distinção entre "membros" do terreiro, em sua maioria pobres (a quem interessaria o aspecto da "mobilidade social") e sua "clientela" interessada na manipulação mágica do mundo. Tal distinção deve ser tomada com todas as ressalvas possíveis. (BAPTISTA, 2009) Em primeiro lugar, para que alguém procure um terreiro, mesmo que esporadicamente, em busca de soluções para seus problemas, por mais pontuais e mundanos que sejam, é preciso que esta pessoa considere o candomblé como uma possibilidade de solução. Assim, aqueles que procuram os "serviços mágicos" dos sacerdotes compartilham alguns pressupostos básicos, no mínimo, de que se trata de um "lugar onde se pode ir" e no qual se pode encontrar alguma ação efetiva, isto é, esta religião deve estar no horizonte do sujeito. A distinção muito rígida entre os fins propriamente religiosos e a "manipulação mágica" também é um tanto problemática, como aponta o próprio Weber (1991, p. 293-294, grifo nosso) ${ }^{49}$

49 Ver também Weber (1991, p. 292) para "oração" e (1991, p. 293) para o "sacrifício". 
É possível distinguir a 'magia', como coação mágica, daquelas formas de relações com os poderes supra-sensíveis que se manifestam como 'religião' e 'culto' em súplicas, sacrifícios e veneração e, em conformidade com isso, designar como 'deuses' aqueles seres religiosamente venerados e invocados, e como 'demônios' aqueles forçados e conjurados por magia. A distinção quase nunca pode ser feita em profundidade, pois mesmo o ritual do culto 'religioso', neste sentido, contém quase por toda parte grande número de componentes mágicos. E o desenvolvimento histórico dessa distinção deve-se com freqüência simplesmente ao fato de que, no caso da repressão de um culto por um poder secular ou sacerdotal a favor de uma religião nova, os antigos deuses continuaram existindo como demônios.

Em segundo lugar, é muito comum que a relação de uma pessoa com um terreiro se inicie com a busca de alívio para alguma aflição e, posteriormente se aprofunde na iniciação (AUGRAS, 1983; RABELO; MOTTA; NUNES, 2002; RABELO, 2008), o que torna instáveis as associações pobres $=$ fiéis $=$ sempre presentes e de classe média $=$ clien tes = esporádicos. É bem possível que a cidade de Salvador, onde o candomblé tem hoje uma visibilidade relativamente grande, fazendo parte de sua imagem "oficial” (SANSONE, 2000; SANTOS, 2005), apresente uma especificidade com relação à São Paulo que se traduza num certo "reconhecimento" bem difundido da existência desta religião, colocando em cheque tais distinções que seriam operantes no caso de São Paulo. Entretanto, as trajetórias que levam fiéis, clientes, visitantes ou amigos da casa aos terreiros - sejam eles ricos ou pobres - não foram exploradas nem se deixou espaço para as experiências que estes vivem em tais percursos. Os diferentes interesses que o candomblé pode vir a atender para membros de camadas sociais diversas, assim dicotomizados, perdem de vista a força do que é especificamente sagrado no candomblé - manifestação ${ }^{50}$ das divindades e

50 A distinção entre "êxtase", "transe" e "possessão" na literatura acadêmica é problemática, uma vez que, de maneira geral, procura-se distinguir modalidades de experiência a partir de seus traços observáveis, e muitas vezes exteriores, como "quietude" ou "agitação", ou entre o 
oferendas - para a análise da constituição das identidades das pessoas que o procuram. Talvez os modelos explicativos acima mencionados sofram de um excesso de rigidez que cristaliza as possíveis relações no e com o terreiro em torno de pares de oposições (mulheres/homens; intelectuais/nativos; pobres/ricos; fiéis/clientes), e todas as nuances das formas de inserção e participação religiosa que não podem ser enquadradas em binômios tornam-se residuais e até mesmo invisíveis por não caberem, de fato, na análise.

Tal como mostram Amaral e Silva (1993) e Oro (1998), o ingresso de pessoas das camadas mais favorecidas nos terreiros se dá em meio a uma série de conflitos, choques e também busca por soluções. O trabalho braçal para a manutenção do templo e a preparação das cerimônias é um vasto palco para a emergência de clivagens de classe e raça que Amaral e Silva (1993) analisam segundo as interpretações oferecidas pelos próprios membros dos terreiros, ou seja, de que os filhos "brancos e ricos" trabalham menos, enquanto os mais pobres e escuros fazem a maior parte do trabalho pesado, reproduzindo, assim, no espaço religioso, as desigualdades e os preconceitos operantes em outros contextos sociais - acusação comum também no terreiro que acompanhei, diga-se de passagem. Dessa forma, mantêm-se dentro do terreiro as avaliações acerca de quais tipos de pessoas são adequadas a que tipo de tarefas. Os conflitos tornam-se mais acirrados ainda na medida em que os adeptos com melhores condições financeiras têm mais facilidade para arcar com os rituais que marcam sua idade de santo e, assim, podem ascender mais rapidamente na hierarquia da casa. (AMARAL; SILVA, 1993, p. 102) Os autores tratam ainda da questão da busca por legitimidade no interior do grupo de culto, indicando as estratégias dos dois "grupos" de adeptos num jogo conflituoso onde a cor da pele é convertida em

que seria o "comportamento" e o que seria sua "interpretação nativa", por exemplo, "saída de si" ou "intrusão de um espírito". (LEWIS, 1977; ROUGET, 1985; MAUÉS, 2003) Para uma crítica a estas distinções ver Crapanzano (1977). Assim, os termos transe e possessão, quando aqui utilizados, o serão como sinônimos de "manifestação", "incorporação", "passagem do orixá" ou "descida do santo", termos muito mais frequentes entre as pessoas acompanhadas. 
maior ou menor prestígio (é a real herança africana versus a situação socioeconômica mais baixa) a depender do contexto da disputa.

Já Oro (1998) revela que, em Porto Alegre, esse tipo de conflito é acompanhado por uma "distribuição" desigual dos adeptos entre terreiros chefiados por sacerdotes mais abastados ou menos, brancos ou negros, seguindo as mesmas relações “[...] parentais e de amizade, associadas à raça e situação social, mesmo na relação com as entidades espirituais" (ORO, 1998, p. 37) reproduzindo o mesmo modelo - e os mesmos preconceitos - vigentes fora do terreiro. Em outros termos, segue-se a lógica do estar entre "gente como nós", nas palavras de uma de minhas entrevistadas, Rosana.

Enfim, a presença dessas pessoas no candomblé começa a ser analisada. Os lugares que ocupam nos terreiros, as relações que desenvolvem, os conflitos em que se inserem e como procuram encontrar soluções práticas e teológicas para o fato de que, para o bem e para o mal, são provenientes de outros contextos sociais começam a ganhar visibilidade na literatura acadêmica. No entanto, embora os autores mencionados logo acima tenham utilizado enfoques relacionais, as experiências religiosas desses indivíduos e as trajetórias que os levaram a cruzar essas distâncias - tanto em quilômetros quanto em falta de familiaridade - ainda ficaram por analisar, talvez pelo simples fato de que não se tenha um trabalho monográfico dedicado ao tema.

As religiões afro-brasileiras, tal como qualquer outra religião, não constituem um universo à parte da sociedade em que existem. Como apontaram Dantas (1988), Amaral e Silva (1993) e Oro (1998), encontram-se inseridas em relações de poder desiguais. Encontram-se situadas ${ }^{51}$ por linhas de forças que as correlacionam com os agen-

51 Com isto quero dizer que as percepções, avaliações e práticas desenvolvidas para com estas religiões situam-se umas em relação às outras através das posições que ocupam com relação aos grupos de agentes que, historicamente, têm carregado essas mesmas práticas. Situar uma prática com relação a valores e apreciações não é o mesmo que procurar estabelecer determinações. Assim, não creio ser possível generalizar as situações aqui descritas para todas e quaisquer relações entre pessoas de certas camadas sociais e certos tipos de religiosidade. 0 que pode ser generalizado, caso se mostre adequado, é a construção metodológica do objeto. 
tes que as atualizam, legitimam, combatem ou denegam; encontram-se situadas frente a outras religiões - e às classes de agentes que as efetivam -, como se fossem "propriedades" de certos grupos de agentes. (BOURDIEU, 1989, p. 2001) Se considerarmos, porém, que estas linhas de força não constituem pura construção teórica, mas que podem traduzir algo relevante para a compreensão da experiência concreta de se viver numa dada sociedade, é preciso atentar para o cotidiano das pessoas envolvidas, pois é aí que se desenvolvem as relações que constroem e atualizam práticas e valores, preferências e avaliações, trajetórias individuais e interpretações. As escolhas e conflitos que podem ser relacionadas com posições sociais se dão no âmbito de ação de pessoas existentes, agindo com outros - e muitas vezes contra outros - numa miríade de situações afetivamente carregadas e nas quais comparecem como agentes encarnados, de fato, a única forma como podem comparecer. Assim, é preciso atentar para as nuances de engajamento na atividade religiosa - sem o quê uma religião corre o risco de tornar-se um corpus literário desprovido de vida - e, ao mesmo tempo, é possível procurar as correlações que classificam e estruturam a pluralidade das práticas. Se o candomblé passou por um processo de abertura ${ }^{52}$ a pessoas de origens raciais, sociais e até nacionais diversas, é relevante interrogar quais as marcas que estas pessoas podem estar imprimindo à religião, tanto quanto quais as especificidades que esta religião pode imprimir a seu modo de vida e à construção de suas identidades.

\section{A QUESTÃO DAS CAMADAS SOCIAIS E O CANDOMBLÉ}

Um dos temas centrais na análise weberiana da religião é o da importância de certas camadas sociais para o desenvolvimento de formas

Talvez seja preciso colocar a própria ideia de "abertura" em questão, já que tal processo parece ter uma longa história, havendo registro de tais pessoas nos terreiros desde o século XIX. (REIS; SILVA, 1989)s Pode ser mais apropriado pensarmos em um processo de maior visibilidade pública (SANTOS, 2005), o que, por sua vez, torna o candomblé uma opção viável para grupos sociais mais diversificados. 
específicas de religiosidade, já que certas mensagens e práticas tenderiam a atrair mais ou menos certos adeptos, a depender das afinidades eletivas entre as propostas religiosas e o estilo de vida da camada social em questão.

O tipo do estado empírico de bem-aventurança ou experiência de renascimento buscado como o valor supremo por uma religião variou, óbvia e necessariamente, de acordo com o caráter da camada que o adotou de forma mais destacada. A classe dos guerreiros cavalheirescos, as classes camponesas e comerciantes, e os intelectuais de educação literária tiveram, naturalmente, tendências religiosas diferentes. (WEBER, 1974a, p. 322)

Os intelectuais religiosos, especialistas educados em tradições literárias e rituais, tenderiam a influenciar a doutrina religiosa no sentido de uma maior racionalização teórica, de um ritualismo acentuado - como nas exigências de conformidade a obrigações tradicionais do confucionismo (WEBER, 1968) - ou do misticismo - como no caso do hinduísmo com sua ênfase na gnose como caminho de salvação - embora restrita aos próprios intelectuais religiosos. (WEBER, 1996) Historicamente, a emergência da primeira via dependeu do êxito de uma profecia exemplar, cujo emissário, normalmente, veio das camadas com um mínimo de cultura intelectualista, ou seja, embora dirigissem sua mensagem aos mais desfavorecidos, usualmente os profetas foram oriundos de camadas mais elevadas e com certo domínio literário (WEBER, 1991, p. 332) e talvez por isto estivessem preparados para questionar as mensagens aceitas e propor a "redescoberta" de seu sentido "verdadeiro". Já os intelectuais do hinduísmo, os brâmanes, compondo uma camada sacerdotal altamente especializada, não ocupada nem com a produção econômica, nem com o governo político, mas sim em manter sua própria posição de especialistas religiosos, direcionavam a religião no sentido das especulações acerca dos estados sagrados e das possibilidades e significados da salvação. No caso do confucionismo, o caráter altamente 
estatal e burocratizado de sua camada sacerdotal - isto é, com uma hierarquia de cargos alcançados através do estudo literário tradicional - imprimiu o forte acento ritualista, bem como a tolerância para com a magia e a fé em espíritos no "jardim mágico da crença heterodoxa” do Taoismo (WEBER, 1968, p. 227-229), embora estas fossem vistas com desdém e certo ceticismo pelas camadas chinesas mais educadas. Mais uma vez, tais tendências podem ser identificadas recorrendo-se a uma análise de desenvolvimentos históricos concretos. Nesse sentido, as próprias categorias utilizadas têm peso relativo e sua operacionalidade reside muito mais na aproximação entre elas (já foi comentado que, historicamente, as distinções são sempre fluidas) do que em sua aplicação isolada sobre as ênfases dadas em certos momentos de certas sociedades para combinações entre, por exemplo, manipulação mágica e súplica aos deuses.

No entanto, não apenas o caráter específico dos especialistas religiosos foi decisivo para as feições gerais que uma religião poderia tomar. Os leigos para quem os especialistas se dirigiam buscando atender às suas necessidades “materiais e ideais” também apresentaram tendências típicas de adesão a certos tipos de religiosidade, imprimindo a elas marcas próprias de seu modo de vida. As classes comerciantes tenderiam para um racionalismo de ordem prática, e as camadas camponesas a manter vínculos com concepções "mágicas" - em grande medida decorrentes da impossibilidade de racionalização completa de sua vida cotidiana dependente de fenômenos naturais - aderindo a religiosidades de caráter ético-racional apenas mediante compromissos efetuados entre tais promessas e seu modo de vida e sob condições ameaçadoras. (WEBER, 1991, p. 321336) As camadas "educadas" em geral, por sua vez, tenderiam a aceitar com facilidade religiões de tipo místico, aquelas com ênfase na experiência individual impossível de ser inteiramente comunicada de forma racional, encontrada, provavelmente, em sua forma mais radical no budismo antigo, cuja absoluta indiferença quanto à existência de divindades e completa rejeição da ordem do mundo 
fazia da aquisição da "tranquilidade" íntima e indiferente a única salvação possível. (WEBER, 1996, p. 205-206)

Como já mencionado, segundo este autor, um processo religioso de abstração teórica teria influenciado a visão de mundo de toda a sociedade moderna calcada, sobretudo, na imagem fornecida pelo cristianismo - especialmente em suas vertentes protestantes - "religião mundial" fortemente racionalizada no que se refere ao estabelecimento de princípios éticos abstratos, embora nem tanto em suas práticas rituais. Na verdade, Weber vai ainda mais longe, identificando no processo de racionalização a mola que impulsionou a religião para a esfera do irracional por excelência, cujo ápice acontece quando a experiência mística "inexprimível” passa a ser o "único além”, e a salvação só pode ser pensada no nível individual. (WEBER, 1974a, p. 324-325)

No caso histórico do protestantismo, a promessa de salvação, negativa com relação a este mundo, combinada a um ascetismo ativo (ao contrário do budismo antigo que pregava a não ação no mundo) orientou a condução da vida cotidiana de camadas cada vez mais vastas no sentido de uma ação metódica e contínua aprazível a Deus. Evidentemente, para que uma ética religiosa muito rigorosa não se perpetue como religiosidade restrita a um grupo de virtuosos (mais uma vez, como no budismo antigo), é preciso uma série de compromissos entre esta e o modo de vida das camadas que as adotam, por exemplo, no luteranismo, a ênfase no combate ao intelectualismo e ao liberalismo, característicos da burguesia urbana, e adequada às necessidades dos camponeses, acabou por resultar no "fenômeno moderno" da imagem do camponês como homem especialmente piedoso. (WEBER, 1991, p. 322-323) ${ }^{53}$

Seria então possível identificar algumas tendências semelhantes, por exemplo, em direção ao misticismo ou ao ascetismo, também entre as camadas "educadas” de hoje em dia? Quais seriam, então, as correlações que podemos estabelecer entre tais indivíduos, na Salvador de

53 Ver também as diferentes variações no desenvolvimento do protestantismo em Weber (2004). 
hoje e o candomblé? A que tipo de interesses esta religião pode atender para estas pessoas? Tenderiam elas a proceder a racionalizações religiosas, ou, ao contrário, a aceitar o irracional como característica própria da religião? Talvez, a princípio seja útil procurar algumas aproximações entre esta forma de religião afro-brasileira e os tipos de religião construídos por Weber.

\section{FORMAS DE PARTICIPAÇÃO NO CANDOMBLÉ: DIFERENTES POSSIBILIDADES DE INSERÇÃO INDIVIDUAL}

O momento mais público do candomblé reside nas festas em homenagem aos orixás. Nelas há música, o toque dos atabaques sagrados e as cantigas de louvação, pessoas e divindades dançam e há um repasto comunal que segue as preferências dos deuses. Um dos pontos fundamentais da festa é quando "o orixá desce", ou "baixa o santo". Na prática religiosa há um enorme número de rituais que vão desde os altamente complexos, que envolvem todos os membros do terreiro, às ações mais simples, que podem ser efetuadas em casa, passando por todos os tipos de ebós, pelo cuidado com os assentamentos e pelo próprio jogo de búzios. No entanto, os momentos mais ansiosamente aguardados e cuidadosamente preparados são aqueles que expõem a face pública da religião: as festas de orixá, as cerimônias finais das iniciações e as obrigações dos adeptos. Nestes momentos as divindades não podem faltar.

Os filhos de santo são preparados para a incorporação dos respectivos orixás através de um processo iniciático que apresenta as características de renascimento: "Este conceito é posto em relevo pela perda do antigo nome e a imposição, no final da iniciação, de um novo nome" (VERGER, 2002a, p. 139) ${ }^{54}$ Interpretação com a qual pai Dary concorda e a qual acrescenta o simbolismo da raspagem dos cabelos. Neste processo, podemos destacar uma série de elementos que constrói a morte do sujeito anterior, preparando-o

\footnotetext{
54 Ver também Verger (2002b, p. 36-49), especialmente das páginas 43-46.
} 
para o nascimento religioso: o período de reclusão durante o qual os iniciandos permanecem no terreiro, constantemente cuidados pelos “mais velhos", abandonando as roupas comuns, vestindo somente branco e tendo os cabelos completamente raspados, isto é, nas palavras de Turner, apresentando demarcadores que apagam as posições sociais na liminaridade do período iniciático (TURNER, 1974, p. 121-122), ,55 do qual o indivíduo emerge com um novo nome, um novo status, enfim, "uma nova vida”. O próprio corpo do iniciando foi tratado, manipulado e preparado para a incorporação das divindades (BASTIDE, 1983), num processo que tem por objetivo o despertar de um "carisma”, a manifestação de uma qualidade excepcional pensada como pessoal e intransferível. O renascimento "mágico" através dos rituais centrados na dança, música, comida, possessão pela divindade e sacrifício de animais tornam tentador classificar o candomblé como uma religião de caráter orgiástico, na qual os elementos mímicos do culto são extremamente relevantes para a manifestação do carisma dos iniciados, considerado como o mais alto valor sagrado. Desse ponto de vista, o candomblé apresentaria a possibilidade de uma experiência de transcendência pessoal e inexprimível que poderia operar como atrativo aos membros das camadas mais formalmente educadas, mas, por outro lado, a característica marcadamente sensorial e coletiva dos rituais também poderia colocar dificuldades ao seu ingresso.

No entanto, é problemático falar do candomblé como um tipo único de expressão religiosa, como já mostrou Prandi. Embora o autor enfatize seu aspecto ritualístico, não nega a importância de outros elementos na atração que a religião exerce sobre clientes e fiéis. (PRANDI, 1991, p. 73-213) ${ }^{56}$ Em primeiro lugar, mesmo os iniciados

\footnotetext{
55 Ver também Verger (2002b, p. 38-39)

56 autor também analisa a noção de "axé" como "carisma", isto é, uma qualidade excepcional que se traduz em força e poder que, do ponto de vista interno ao grupo, é responsável pelo seu sucesso e expansão. (PRANDI, 1991, p. 103-118) A mesma ideia pode ser encontrada em Silverstein (1979).
} 
preparados para a incorporação têm outras formas de relação com as divindades, principalmente fazendo oferendas e cuidando dos locais sagrados. Ainda que transformados em "recipientes" dos deuses, em qualquer momento eles podem ocupar uma eventual posição de "clientes do mago" quando precisam consultar os búzios - o que pode ser feito exclusivamente por uma pessoa em cada terreiro ${ }^{57}-\mathrm{e}$ realizar algum ebó com vistas a fins práticos. (BAPTISTA, 2009) Em segundo lugar, aqueles do grupo de culto que não entram em transe também são fundamentais. Ocupando os cargos de equede e ogã, estariam estas pessoas "menos ligadas" ao sagrado? Acredito que não. Sua eleição é feita diretamente pelas divindades, elas também se submetem aos rituais de iniciação que incluem recolhimento e, a depender da casa, raspagem da cabeça (expressão máxima do renascimento, segundo pai Dary), também ficam reclusas no terreiro durante a iniciação, ao término da qual são apresentadas à comunidade numa cerimônia em que se dá a conhecer seu novo nome, embora este seja pronunciado pela divindade que as elegeu, já que seu orixá pessoal "não desce".

Suas funções não são apenas "burocráticas”, pois também envolvem o contato com o carisma, o axé, tais como vestir e acompanhar os orixás que dançam, sacrificar animais e, a mais visível, tocar os tambores sagrados. Mais ainda, certos procedimentos rituais apenas podem ser executados por aqueles que receberam determinados cargos e, na sua ausência, pelo chefe do terreiro, desse modo, equedes e ogãs podem deter uma quase exclusividade sobre algumas tarefas. A “pureza” de seus corpos também é imprescindível para a execução de seus encargos, e eles devem se submeter às interdições específicas a suas posições, por exemplo, um ogã não pode ter contato com objetos sagrados se tiver mantido relações sexuais no dia anterior e não tiver sido "limpo" com o banho apropriado de ervas. Apesar de

\footnotetext{
Mais uma vez, uma série de exceções à regra podem ser encontradas, sobretudo quando o pai ou a mãe de santo passam por uma doença grave ou estão muito idosos, e outras pessoas assumem a tarefa de jogar os búzios.
} 
não serem "recipientes do sagrado", em sentido estrito, sua prática religiosa compartilha do caráter dos "magicamente renascidos", altamente marcada por tabus que delimitam o modo de manter seus corpos ritualmente "puros". Uma vez, ao questionar uma equede, durante uma festa, sobre o modo rápido como elas percebem a chegada de um orixá num filho de santo, obtive uma resposta bem direta: "É fácil, a gente sente a energia".

Sua autoridade, porém, decorre de seu cargo. Normalmente, os membros que não entram em transe não podem ser babalorixás ou ialorixás, as autoridades máximas do terreiro, e, ao contrário destes, podemos dizer que a fonte de sua autoridade não é carismática, mas decorre de uma "transmissão de carisma" em razão da eleição por uma divindade incorporada e dos rituais iniciáticos. Portanto, "feitura" e "confirmação" 58 apresentam algumas características bastante divergentes, ao mesmo tempo em que compartilham outras.

Equedes e ogãs "nascem adultos", e percorrem apenas implicitamente os estágios ${ }^{59}$ de status pelos quais os filhos de santo passam de modo explícito. Isso significa dizer que uma equede nova tem, efetivamente, status inferior a uma ebomi, porém esta distância diminui muito se a primeira foi socializada no candomblé desde a infância. Formalmente uma equede é considerada "mãe" dos filhos da casa ou, ao menos, "tia”. Um exemplo disso pode ser visto na obrigação dos iaôs de tomar a benção a "todos os mais velhos" ao chegar no terreiro, o que inclui equedes e ogãs que estejam presentes. Aliás, é importante ressaltar este aspecto do candomblé: a hierarquia não é baseada apenas na senioridade, embora este seja o princípio explicitado pelos grupos de culto, mas também na distribuição dos cargos. Por exemplo, ser Axogun - ogã que detém o privilégio e o dever de sacrificar os animais votivos - é uma posição de elevado prestígio,

58 Rituais de iniciação daqueles que entram em transe e daqueles que não entram, respectivamente.

59 O que chamo de "estágíos" são os anos de iniciação marcados pelas obrigações de um, três, cinco e sete anos, que representam alguma mudança no status do iniciado. 
já que esta função pode ser exercida tão somente por seu dignitário ou pelo chefe do terreiro. A distribuição de tais cargos importantes pode, inclusive, despertar ciúmes (AMARAL; SILVA, 1993, p. 102), uma vez que a determinação de quem deve ocupar cada um é, ao menos teoricamente, feita pelas divindades e pode "atravessar" outras posições - e expectativas - dentro do grupo. No Torrundê, durante os anos da pesquisa, o cargo de Axogum ficou sob a responsabilidade de um dos homens jovens de classe média que havia se iniciado há mais tempo. Nesse caso, contudo, nunca ouvi alguma fofoca ou comentário depreciativo a seu respeito, mesmo com suas limitações profissionais de disponibilidade e, talvez, isso se devesse à maestria com que aprendeu a desempenhar suas funções. Neste caso, temos um exemplo de como as posições de prestígio, as intrigas e o modo de inserção religiosa não são determinados por uma ou duas características do sujeito, mas processualmente estabelecidos num conjunto complexo de fatores.

Tal como filhos e filhas de santo (os que recebem as entidades em seu corpo), ogãs e equedes têm seus orixás de cabeça identificados pelo jogo de búzios, seu juntó ${ }^{60}$ e seu Exu e passam por um processo iniciático que envolve elementos de todas essas divindades, configurando uma espécie de identidade espiritual única, uma vez que se dá no entrecruzamento entre diversos seres espirituais (AUGRAS, 1983; GOLDMAN, 1985; SEGATO, 1995; NICOLAU-PARÉS, 1997):61 o orixá que os escolheu, o odu ${ }^{62}$ e as demais entidades pessoais. Um

60 Ou "segundo santo", é aquele que tem mais influência sobre a vida de uma pessoa logo depois do orixá de cabeça. A sequência de divindades que configura a identidade espiritual é conhecida como "carrego". Goldman (1985) se refere a sete orixás que são identificados numa ordem decrescente de proximidade com o iniciado. No Torrundê costumam ser identificados dois orixás já antes da iniciação, mas o número total não é pré-definido, dependendo do jogo de búzios.

${ }^{61}$ Ver também Bastide (1973).

62 Trata-se de um "caminho espiritual" traçado antes do nascimento que determina os tipos de "energia" que uma pessoa trará para esta vida. Estas energias não são os orixás - que são "energias da natureza", por exemplo, da água ou do vento - e dizem respeito a aspectos da vida como afetividade, saúde, equilíbrio financeiro etc. É uma espécie de "destino", porém 
ogã e uma equede suspensos, porém ainda não confirmados, permanecem no terreiro como abiãs tal qual aqueles que serão iniciados para incorporar seus orixás. Na verdade, podemos dizer que alguém cuja iniciação ainda não se deu - seja qual for a posição que ocupará no grupo de culto - encontra-se numa situação bastante ambígua. Por um lado, já houve um certo "chamado" da divindade e, assim, a provável posição de tal pessoa já foi explicitada. Por outro, há sempre o risco de que as expectativas iniciais não se cumpram, sobretudo no caso de abiãs que passam anos sem incorporar e acabam por não fazê-lo, a despeito da suspeita de que poderiam entrar em transe, e de ogãs e equedes suspensos, pois estes ainda podem cair no santo ao participarem de rituais mais restritos. Há uma brincadeira no terreiro que consiste em chamar abiãs que ainda não incorporaram de "é queda", sinalizando a indefinição de seu papel.

De toda sorte, para ser de fato um membro do candomblé é imprescindível que qualquer pessoa se submeta aos rituais iniciáticos que, segundo Goldman (1985), operam uma progressiva construção da pessoa. A iniciação no candomblé não se dá de uma vez por todas, sendo constantemente renovada nas obrigações, cerimônias públicas que comemoram, como já mencionado, os “aniversários” de um, três, cinco e sete anos de iniciação. Estas cerimônias, inclusive a iniciação propriamente dita, estabelecem e fixam a relação de um indivíduo com uma série cada vez maior de divindades. A princípio, esta se reduz ao orixá de cabeça, ao Exu individual, ao caboclo, nos terreiros que o cultuam, e ao erê particular, que sempre acompanha cada orixá, além do Egun, no caso analisado por Goldman. Para muita gente estas entidades já se manifestavam antes do ingresso no terreiro. Caboclos, erês e Exus são pródigos em aparições não anunciadas e, muitas vezes, surgem em casa para ajudar seus filhos, ou parentes e amigos destes. Não obstante, antes da iniciação tais manifestações

não fatalista, já que todas estas energias podem trazer um aspecto positivo e um negativo, cabendo ao babalorixá efetuar os rituais necessários para que todas elas atuem de forma construtiva na vida da pessoa. 
são consideradas um tanto instáveis, podendo ser muito mais prejudiciais do que benéficas. Como Goldman (1985) argumenta, o processo de iniciação individualiza as próprias divindades que passam a ter um nome próprio ${ }^{63}$ e uma representação material individualizada, o assentamento. Uma pessoa iniciada não é mais somente filha de Ogum, por exemplo, mas filha de um Ogum específico cujo nome foi anunciado publicamente no barracão. Ao longo dos sete primeiros anos de iniciação ${ }^{64}$, várias divindades são singularizadas dessa forma, construindo uma rede de relações na qual o iniciado termina por ocupar uma posição que é única e exclusiva. Assim, o vínculo com esta religião vai sendo lentamente firmado, ao mesmo tempo em que vai progressivamente construindo uma pessoa mais completa e equilibrada porque é singular em suas relações com o sagrado.

Nicolau-Parés (1997, p. 162-172) segue adiante nesta trilha mostrando como distintas ortodoxias, operando em terreiros de diferentes tradições, articulam diversamente a identidade espiritual individual que pode se dar num continuum que teria num extremo a incorporação de um único vodun ${ }^{65}$ - na Casa das Minas - e no outro a incorporação de uma ampla gama de entidades, organizadas por linhas pessoais, que podem, algumas vezes, não ter uma identificação bem definida. Assim, diferentes tradições culturais podem oferecer noções de pessoa distintas que permitem articulações diferenciadas das identidades espirituais dos membros de um terreiro. De toda forma, mesmo nos casos mais extremos, se mantém a construção processual dessa identidade e fica evidente a importância da experiência

\footnotetext{
63 No Torrundê este é o nome do orixá e não costuma ser usado. 0 nome de iniciado de um filho de santo é composto por partes do nome do orixá, mas não é o mesmo. De toda forma, tratam-se de nomes de uso restrito ao grupo de culto. Ver também Silva (1998, p.40).

64 Na maior parte dos casos, tais cerimônias não podem ser realizadas exatamente na data da iniciação. Uma série de empecilhos faz com que sejam, em geral, atrasadas, principalmente em virtude da necessidade de combinar obrigações de pessoas com disponibilidades muito diferentes para voltar ao recolhimento no terreiro e as dificuldades financeiras para realizar cerimônias complexas e caras.

65 Equivalente a orixá na nação jeje. Na angola o termo é inquice.
} 
da divindade no ritual para sua identificação. Aqui encontramos uma grande diferença entre a iniciação e a confirmação, pois é preciso lembrar que equedes e ogãs "nascem adultos", ou seja, seu status é alcançado de maneira mais imediata, embora tais "comemorações" se apliquem também a eles, conferindo-lhes prestígio gradativamente mais elevado, ao menos em terreiros com influência da nação angola. Também em seu caso há uma singularidade devida às relações individualizadas com a esfera do sagrado, embora esta possa não ser vivida de maneira tão marcante.

Podemos, portanto, dizer que o candomblé apresenta uma ambiguidade que torna sua tipificação uma tarefa ainda mais complexa, uma vez que se pode enfatizar seu aspecto institucional, onde a autoridade máxima e o fim sagrado procurado têm caráter carismático, ou pode-se enfatizar as experiências que esta forma de religião permite e suas consequências para os indivíduos e, aqui, as possibilidades se ampliam. ${ }^{66}$ Aliás, este pode muito bem ser o grande atrativo do candomblé para as camadas médias urbanas: apresentar várias formas de religiosidade no interior de um só grupo de culto, o que oferece ao indivíduo possibilidades de inserção, mas principalmente, de experiências religiosas diversas. Se, por um lado, a ênfase maior é dada à autoridade carismática em função da experiência do transe, há também, por outro, a possibilidade de se ocupar posições cuja autoridade e cujas atividades apresentam um caráter mais racionalizado, ou seja, que seguem regras já explicitadas e se configuram em cargos correspondentes. ${ }^{67}$

A própria estrutura da iniciação religiosa volta-se para a construção de posições individualizadas, possibilitando que cada um interprete sua história como uma conjunção única. Ao ingressar no

${ }^{66}$ É preciso não esquecer que há outro elemento fundamental além do transe: a oferenda. Um ebó pode ser tanto um elaborado ritual comandado pela iálorixá ou pelo babalorixá, ou uma simples oferta de algo que o próprio adepto entrega ao orixá no local adequado, e, portanto, pode ser feito por qualquer um que detenha os conhecimentos necessários.

67 Ver também Sansi (2007) para uma discussão sobre "dom" e "iniciação" como fontes de poder no candomblé. 
candomblé o indivíduo deixa para trás uma série de interpretações de si próprio, mas não para se anular frente ao divino, não para se despersonalizar. Ao contrário, como afirmou Augras (1983, p. 60-93), deixa-se muito de si mesmo para trás para expressar a sua "natureza mais profunda". (TURNER, 1974) Este é meu ponto: o candomblé apresenta características adequadas aos interesses ideais de pessoas que compreendem a si próprias como indivíduos que "optam" e é, portanto, o centro biográfico de histórias singularizadas por estas opções, e ainda apresenta uma especificidade: a passagem pelo rito de iniciação. Esta também favorece que a religião surja como um elemento de distinção pessoal frente à origem sociofamiliar. Desse ponto de vista, podemos dizer que para parcela da classe média de Salvador, o candomblé é uma religião que surge como "solvente" de outros laços sociais e fidelidades anteriores, corolário de ter-se tornado uma religião “universal”. (PIERUCCI, 2006)

Temos aqui duas facetas de um elemento que pode ser responsabilizado pela atração que o candomblé vem exercendo para membros da classe média escolarizada, a possibilidade de inserção e experiências religiosas distintas e o processo singularização religiosa. Resta, porém, ainda um aspecto da questão: a que expectativas a religião responde para que pessoas estranhas a procurem pela primeira vez? Para refletir sobre isso, convém analisar quais os motivos alegados para visitar os terreiros e para o ingresso na religião.

Pois bem, no caso das pessoas entrevistadas neste projeto, todas elas eram advindas de um universo católico e/ou espírita e num dado momento de suas vidas decidiram se iniciar no candomblé. Em que momento isto ocorreu? Para Paulo foi durante a infância e não podemos dizer que houve um ato de escolha em seu caso. Ele tinha apenas 8 anos quando sofreu um grave acidente, ficando hospitalizado entre a vida e a morte, e o caminho encontrado por sua avó materna para salvar o menino foi através do candomblé. Assim, Paulo foi o único dos entrevistados que cresceu na religião. Sua família continua católica e ele contou que mantém grande afinidade com 
esta religião. É interessante notar que Paulo contou a história de sua iniciação como algo complicado e assustador, mas já na adolescência, quando a família descobriu sua ligação com o candomblé, ele acabou por abandoná-la pela religião, inclusive deixando a casa paterna e passando por grandes privações. Somente aos 18 anos, quando passou no vestibular, Paulo iniciou uma reaproximação com sua família, recorrendo à mesma avó que o levou ao candomblé. Assim, embora a iniciação não apareça para ele como uma opção individual, sua trajetória mantém esse caráter em sua narrativa. Para todos os outros entrevistados essa ideia de religião como "assunto de foro íntimo" tem tom menos dramático e, ao mesmo tempo, mais afirmativo da noção de que a religião é uma opção individual. Fábio, o companheiro de Ana, me contou que não consegue compreender como "pessoas esclarecidas" podem deixar de levar seus filhos para o terreiro, no que Ana discorda, pois pensa que cada um deve decidir por si quando for adulto.

Reencontramos aqui um ponto que já foi destacado com relação às profissões exercidas, pois ambas as trajetórias aparecem como opções pessoais, como caminhos que se trilha em busca de "crescimento", seja espiritual, seja material e de autorrealização. Assim, o candomblé surge de mais uma maneira: como um caminho de autoconhecimento. Este ponto, porém, será retomado mais adiante devido à sua relevância para a discussão de identidades pessoais no presente caso. O que quero enfatizar, por ora, é a coincidência de perspectivas no que diz respeito à trajetória profissional e à religiosa.

Quanto aos outros entrevistados, Rosana e Francisco ainda não se iniciaram - e talvez nunca venham a fazê-lo - seis se iniciaram com cerca de 20 anos de idade e sete deles com 30 anos ou mais. Podemos distinguir aqueles que se ligaram ao terreiro ainda bem jovens daqueles que o fizeram já bastante adultos, mas as diferenças de opiniões e ideias nas entrevistas não são muito marcadas tornando difícil dizer se são produto da idade e/ou de características pessoais. De toda forma, para todos eles é importante a ideia de que optaram pelo candomblé como religião. 
Este tema reaparece, ainda, de outra forma. Dos motivos alegados para o contato inicial com a religião, Marta e Ana (ambas filhas de santo) começaram a frequentar o terreiro levadas pelos namorados. Ana conheceu o Torrundê através de Fábio, também filho de santo, somente por curiosidade pela religião do namorado. Marta foi levada por seu parceiro, que era apenas frequentador, assistiu a algumas cerimônias, mas adoeceu e precisou de uma consulta porque iria se submeter a uma cirurgia, desse modo foi também "por necessidade". Elas "foram ficando" no terreiro, conhecendo a religião e as pessoas até que acabaram por se identificar com o candomblé e passaram dois e quatro anos como abiãs, respectivamente.

Seis pessoas contaram-me que se aproximaram do candomblé por "curiosidade" ou um "interesse cultural" um tanto inespecífico. Dois ogãs e dois filhos de santo narraram um despertar do interesse pelo aspecto estético do candomblé ou por o considerarem como um patrimônio cultural digno de maior atenção. Este é o caso de Francisco, que devido à curiosidade despertada pela leitura de trabalhos acadêmicos procurou um terreiro para um jogo de búzios, gostou do pai de santo e começou a frequentar as festas. Irene pode ser considerada um caso exemplar dessa situação. Ela desejava fazer um projeto de mestrado em Pedagogia que valorizasse a "cultura negra" na educação infantil. Por esse motivo foi levada por uma amiga a conhecer o terreiro do qual esta participava há quase duas décadas:

Mas o [terreiro], a pergunta que você me fez, o [terreiro], veio, olha, em, em tese, pra mim como uma consequência [do trabalho acadêmico que ela vinha desenvolvendo], agora, se considerar, é, a nível dos, desígnios do orixá, da vida espiritual de uma pessoa, eu acho que toda a vida eu fui de Oxum.

Ernesto foi apresentado à sua mãe de santo por uma conhecida pelo fato de ter morado três anos e meio na África. Fábio nem sabe dizer ao certo porque começou a ir ao terreiro. Ele pertencia a uma turma de amigos do bairro da Barra quando um deles começou a fre- 
quentar o candomblé e levou os outros. Numa espécie de aventura adolescente (e contestatória, podemos dizer, a partir dos conflitos familiares que tais “visitas” causavam), os rapazes começaram a trabalhar nas obras do terreiro, em Paripe. Muitos desistiram, mas três deles se iniciaram e dois continuam atuantes. Temos, então, dois motivos básicos para se procurar um terreiro: a necessidade de uma consulta ou a curiosidade. Como também já foi mencionado, podemos imaginar que o "interesse cultural" tem alguma relação com o movimento de contracultura e de valorização de uma certa "autenticidade" que, no caso de Fábio, soma-se ainda a uma contestação juvenil. Assim, para muitas dessas pessoas escolarizadas o candomblé surge como um objeto cultural digno de atenção. (PRANDI, 1999; SANSI, 2003) Já os motivos para o ingresso não são claros. As pessoas "gostam” da casa, "gostam" do pai ou mãe de santo, vão "ficando" e acabam por se iniciar, tanto aquelas que foram procurar por serviços espirituais quanto as que foram por curiosidade, como Antônia que, "quando viu, tava de saia”.

$\mathrm{Na}$ verdade, a amizade com alguma pessoa de candomblé tem sido fundamental na descoberta da religião, já que os familiares dos entrevistados não costumavam frequentar terreiros e, quando o faziam, não eram familiares próximos (como as tias de Ana e de Pedro) ou simplesmente não os levavam, como o pai de Marta, cuja avó era filha de santo e ela nem sabia disso. Como vimos, os colegas de faculdade e de trabalho têm um papel importante neste momento, pois em geral são eles que iniciaram o contato entre os entrevistados e o terreiro. Em apenas um caso, Paulo, foi a avó que o fez, através de uma vizinha. Isto reforça a ideia de que há um distanciamento da família no início destas trajetórias religiosas. Já a relação de amizade com o líder do terreiro tem se mostrado importante na decisão de ingressar na religião. É o caso de Helena, que me contou sua busca por um caminho espiritual pessoal (tendo conhecido o catolicismo, o kardecismo e a umbanda paulista) e que, ao descobrir que um amigo seu era pai de santo, decidiu participar ativamente, acabou sendo 
suspensa e se confirmando equede. Dois ogãs também disseram que "foram ficando" pela amizade que passaram a nutrir pelos sacerdotes de seus respectivos terreiros.

Antônia foi levada ao candomblé por uma amiga, por estar passando por um momento de grande desorganização de sua vida pessoal, com problemas familiares, financeiros e de saúde. De início ela foi fazer uma consulta e os trabalhos necessários, mas, então, contoume que foi desenvolvendo uma grande amizade pela mãe de santo e gostando da religião. Começou a participar das atividades como abiã e, quatro anos depois, foi suspensa equede. Hoje ela tem 10 anos de iniciada. O babalorixá Robson também foi levado a um terreiro por um amigo para conhecer a religião, não gostou do ritual a que assistiu, mas voltou porque se encontrava em um momento de crise pessoal e pensou que poderia encontrar a solução para seus problemas através do candomblé. Como transparece na sua fala que abre este capítulo, hoje, ele pensa que este não é um motivo legítimo para o vínculo religioso, pois a transformação que a religião opera "é interior". Equede Hortência é mais uma pessoa que foi levada ao candomblé por um amigo, pai Dary, que hoje é seu pai de santo. Na verdade, ela já havia assistido a uma entrega de decá, há cerca de 27 anos, mas não se interessou pela religião na época. Por volta de 1994, porém, foi convidada pelo babalorixá, que ela já conhecia e sabia ser uma "pessoa respeitosa", resolveu ir ao terreiro recém-aberto, gostou, foi ficando e logo depois foi suspensa. Ela afirma que já conhecer o caráter de seu amigo foi o que mais pesou para que ela imediatamente se sentisse à vontade para aceitar o cargo, pois pressentiu que ficaria ali "para o resto da vida”. Para Fábio foi o fato de ser um terreiro novo e cheio "de gente jovem" o que pesou. Pai Dary, para ele, apesar de ter mais idade, tinha a "cabeça" dos jovens.

Por outra via chegamos novamente ao mesmo ponto: a convivência no terreiro, para estas pessoas, não se dá no âmbito das relações familiares, mas sim no das relações de amizade e coleguismo. Isto, porém, não significa que tais relações se desenvolvam a partir 
da convivência no grupo. João Alfredo foi exemplar a esse respeito. Quando perguntei se ele havia desenvolvido amizades no terreiro, ele respondeu:

Ah, sempre! Aqui, é, você faz muita amizade porque vem muita gente de fora, né? Muito politico, vem muito empresário, tudo, a gente termina fazendo amizade também.

Para os entrevistados não foi algo problemático admitir que as amizades criadas no terreiro se deram entre pessoas do mesmo nível de escolaridade e da mesma classe, com raras exceções, uma vez que isto ocorre no desenvolvimento de suas relações de amizade de maneira geral. O grupo religioso não representa, para essas pessoas, uma grande oportunidade de ampliar suas relações sociais. Ainda que esta possibilidade não seja excluída de todo, ela é quase limitada aos contatos que poderiam ocorrer em vários outros ambientes, como escolas e faculdades, redes de amigos ou mesmo via internet, hoje em dia. No geral, o terreiro enquanto conjunto humano é sentido como um local de fofocas, invasão de privacidade e conflitos, muito mais do que como uma rede capaz de oferecer apoio a seus membros. Com isto não quero dizer que os membros desta classe média escolarizada não recorram ao terreiro em momentos de crise, nem que não encontrem apoio ali, mas este aspecto não é valorizado - muitas vezes sequer é mencionado - ao passo que as situações negativas são sempre exploradas nas entrevistas.

De toda forma, os motivos alegados para entrar em contato com um terreiro podem ser divididos em dois grandes grupos. De um lado temos aqueles que se encontravam em uma situação problemática e que foram a um terreiro pela primeira vez para um jogo de búzios e, a seguir, para os ebós prescritos. Estes poderiam ser classificados como "clientes". Mais uma vez, é preciso ter em mente que alguém não se dispõe a se apresentar como "cliente" de uma religião sem que seu horizonte de possibilidades apresente tal prática como possível. Como vimos, aqueles que procuraram um terreiro para a solução de 
problemas imediatos o fizeram com o auxílio de um amigo, da mesma maneira como poderiam ser aconselhados a procurar um "psicanalista formidável”. Com isto quero dizer simplesmente que a distinção analítica entre esferas da ação humana deve ser contrabalançada com o fato de que na vida individual é uma mesma pessoa que "trafega" entre todas elas, e o "cliente" um dia se torna "filho" da casa. Este ponto fica mais claro ao tratarmos do outro grupo: as pessoas que foram a um terreiro por "interesse cultural". O que significa ir conversar com uma mãe de santo para trocar impressões sobre a vida na África? Ou frequentar um terreiro porque se leu ou se quer escrever a respeito? Não seria esta uma visão um tanto “secularizada” da própria religião?

Um terreiro é um lugar onde alguém pode ir em busca de "cultura" e não do "sagrado" propriamente ${ }^{68}$ dito. É claro que pode ser difícil manter esta noção atuante após a iniciação, quando se deve, ao menos em tese, reconhecer a força e a liberdade de ação dos orixás, mas isto não impede que algumas pessoas a reconheçam como motivação inicial do interesse pela religião. Irene, que chegou a fazer “apresentações” das danças dos orixás antes de conhecer o terreiro a que pertence comenta:

Irene - Então ele [o amigo do candomblé] olhou pra mim e disse: 'é uma, é um congresso'. E que a gente ia dançar. Eaí ele fez, 'Dance Oxum'. Cê vê, hoje eu sô terminantemente contra isso porque não faz o menor sentido, né? Alguém se vestir de orixá e dançar a dança do orixá. Hoje eu vejo que na época foi uma coisa tão... inocente. E ele disse: 'você, acho que você é de Oxum. E você é de Oxum Apará'. Quer dizer, até a qualidade da Oxum ele deu, né? E dai por diante eu era de Oxum. Mas sem maiores consequências, eu não sabia, porque hoje tem, tem arquétipos até junguianos, né? Que se coloca, que se leva como referencial, mas eu não... esse foi o meu primeiro contato com a palavra Oxum.

68 Ver Sansi (2007) para uma discussão do sincretismo como processo histórico-cultural que, no caso particular do candomblé, possibilitou a construção da imagem pública do "candomblé como cultura", num intercâmbio entre especialistas religiosos e intelectuais. 
Luciana - Mas por que você ia dançar, se você não tinha $[\ldots]$.

Irene - Porque no congresso precisava apresentar uma dança que representasse a Bahia.

O que não estava colocado de antemão para estes adeptos como possibilidade era exatamente isso: as divindades como agentes. $\mathrm{Ou}$ seria apenas a possibilidade de que qualquer divindade seja encarada como agente? Este é o tipo de questão para a qual não se encontra resposta, mesmo porque as pessoas não saberiam respondê-la, em muitos casos por nunca terem pensado sobre isso. Na verdade, tanto faz uma afirmativa como a outra já que as duas têm o mesmo pressuposto: desconsiderar que a categoria especial de agentes, desencarnados, diria Sansi (2003, p. 135), com os quais se tem que negociar e lidar, é uma proposição específica a cada grupo religioso. A partir disso percebe-se que tanto desconhecer a atuação desses agentes, quanto considerar qualquer um como equivalente representam duas possibilidades do mesmo mundo: aquele em que a religião não é uma instituição que perpassa todas as esferas de nossa vida (e este pode muito bem ser um dos pontos mais afetados pelo vínculo com o terreiro). Mais uma vez, nos deparamos com uma situação que pode ser chamada de sociedade secularizada, onde várias alternativas religiosas - e várias formas de ver a mesma religião - podem conviver e na qual um indivíduo pode trafegar por várias delas. Entretanto há algo que pode ser mais forte para o caso de pessoas escolarizadas de classe média: a ênfase numa dimensão cultural. Como vimos no primeiro capítulo, para estas pessoas a distinção de classe passa pela "educação" e pela "cultura". Assim, num ambiente em que o candomblé é apresentado como "cultura autêntica", como é a cidade de Salvador, o resultado do "sincretismo cultural" (SANSI, 2007) efetuado por religiosos e acadêmicos pode ser mais um dos atrativos para os membros da classe média. Mas uma vez que se chega a um terreiro, como se interpreta a religião? 


\section{RELIGIÃO COMO ESFERA DO IRRACIONAL: DE ONDE SE ESPERA QUE VENHA A RACIONALIZAÇÃO?}

Considerei acima a hipótese de que as camadas médias poderiam ser portadoras de grandes ambiguidades no que toca aos tipos de religião que lhes atraem e que poderiam, portanto, aceitar religiões altamente racionalizadas tão bem como expressões da religião como esfera do irracional, ao modo das camadas "cívicas” de que falava Weber (1974b, p. 327):

Finalmente, podemos considerar as camadas "cívicas" no sentido que a palavra tem na Europa ocidental, bem como as camadas que a elas correspondem em outros lugares: artesãos, comerciantes, empresários dedicados ao artesanato e seus derivados, que existem apenas no Ocidente moderno. Evidentemente essas camadas foram as mais ambíguas com relação às posições religiosas que lhes estavam abertas.

Agora se faz necessário confrontar esta possibilidade com a situação particular encontrada entre as pessoas investigadas. No início das análises, parti do pressuposto de que a possessão, por ser uma experiência individual inexprimível verbalmente, consistiria numa "irracionalidade" com a qual era preciso aprender a lidar, principalmente no caso do candomblé, onde o modelo de manifestação das entidades exige a ausência de memória de quem a vive. No entanto, este ponto não se sustentava diante das experiências e receios narrados nas entrevistas. Quando perguntadas sobre a possessão, sobre sua reação inicial à presença das divindades nos corpos dos iniciados, as maneiras pelas quais estas pessoas manifestaram espanto ou descrença foram por demais variadas e contraditórias para permitir qualquer tomada de posição com relação à "irracionalidade" da experiência da incorporação. Embora pudessem duvidar da presença efetiva das entidades em alguns casos particulares, o que é comum ocorrer no candomblé, principalmente nos primeiros contatos com terreiros, isto não significa que houvesse algum tipo de expectativa de racionalização dessa prática religiosa. Mesmo 
aqueles que passaram a receber orixás, caboclos e erês revelaram uma espécie de receio que nada tinha de específico para uma classe ou ausência de contato anterior com a religião. Ana, por exemplo, contou que no início seu orixá não "passava completamente" e ela se sentia "muito mal", perdia o equilíbrio e o controle motor sem "perder a consciência”. Ela também tinha dúvidas quanto à legitimidade de sua experiência. Entretanto, este tipo de "desconforto", de dúvida e receio é frequente nas primeiras experiências de incorporação mesmo para pessoas que frequentaram um terreiro desde crianças. O que é mais interessante em seu discurso é que até hoje ela não gosta de receber Iansã em outros terreiros aonde vai como visitante e muito menos de "ficar de erê", pois tem um pouco de vergonha de se portar como uma criança pequena e mal educada.

O medo de "sair do ar" e perder totalmente a consciência, que Rosana expressava, me levou a pensar que uma experiência anterior no espiritismo poderia ser responsável pela familiaridade com a manifestação que muitos entrevistados relataram, pois já teriam contato com a manifestação de espíritos, embora num modelo oposto, que exige a lembrança dos eventos ocorridos. Para o babalorixá Robson, porém, cuja trajetória religiosa inclui a passagem pelo espiritismo na função de médium, a incorporação não representou sua maior dificuldade no início do contato com os membros do terreiro, a despeito de ter contado que pensou estar sofrendo um derrame na primeira vez que Obaluaiê passou, pois viu suas mãos e braços se entortarem sem controle de sua vontade até que caiu no santo completamente. "Fui carismática, né? Depois achei que é bem mais fácil receber Oxum do que Jesus Cristo", contou Irene. Portanto, as variadas reações que foram expressas e os percursos que levaram as pessoas de um certo estranhamento - que nem sempre ocorreu - a um certo receio e, finalmente, à normalização eram bastante comuns nas histórias de membros do candomblé e não me permitia tirar qualquer conclusão sobre uma possível aceitação do "irracional” na prática religiosa, além de ser comum a pessoas de outras classes e outras ori- 
gens religiosas. As respostas de duas equedes são ilustrativas do problema enfrentado:

Quer dizer, tirando o medo de dar santo, que todo o mundo tem, não teve conflito nenhum. [...] A incorporação 'nos outros', [risos] foi sem complicação nenhuma. Não teve complicação, não. (Antônia, ênfase na entonação).

Porque eu acho que é uma coisa que de uma certa forma, interfere na sua vida pessoal, profissional e tudo o mais, né? Eu mesma perguntava, falei: 'meu Deus, que coisa, né? Será que eu ia querer, é, receber, fazer, ter que aceitar, ter que fazer, ter que receber as pessoas, ter que dizer, ter que fazer os trabalhos e tudo o mais'? Não sei. No meu caso eu não, não recebo nenhuma entidade, mas eu acho que deve ser uma coisa que cria um certo conflito. (Helena)

Afinal, há "complicação” ou não? Trata-se de uma experiência que se admite para os outros e não para si? As respostas obtidas eram altamente ambíguas, não permitindo qualquer conclusão. Por vezes parecia haver um conflito no início do vínculo religioso que se diluía com o tempo. Por vezes esse conflito parecia permanecer, embora restrito às incorporações fora do próprio terreiro. Outras vezes ele parecia ser afastado pela iniciação, que eliminava esta possibilidade. Enfim, o problema residia em partir do princípio de que a incorporação era essencialmente uma experiência irracional. Como argumentou Bastide (2001), a possessão tem lugar na estrutura de um ritual, aliás, ela mesma é um ritual, e, mesmo excluindo a lembrança dos atos praticados, não exclui a comunicação entre os participantes, ao contrário, exige uma fina interação entre eles. Apenas esta comunicação não ocorre segundo os modelos de transmissão que normalmente consideramos "racionais". A incorporação das divindades, portanto, só pode ser compreendida como valor sagrado a ser alcançado, e as maneiras como isto deve ocorrer são altamente regulamentadas. Nicolau-Parés (1997, p. 177-197) mostra como a incorporação por diferentes entidades é articulada entre enquadramentos rituais específicos e concepções acerca 
das identidades desses seres, correlacionados às tradições específicas de cada terreiro e suas casas matrizes.

O que era expresso nessas respostas não dizia respeito à irracionalidade, mas sim, novamente, àquela possibilidade de mais de um tipo de experiência no mesmo grupo de culto. Religiosamente o transe não é para todos. Alguns são escolhidos para receber as divindades em seus corpos e outros para cuidar das divindades fora de seus corpos. Sociologicamente o transe tampouco é para todos: nem todas as pessoas entretêm expectativas semelhantes quanto a suas experiências religiosas. Embora isto possa ser generalizado para qualquer classe social, parece particularmente adequado a pessoas que compreendem seu vínculo religioso como uma espécie de carreira pela qual se optou. "Decidir" se iniciar num terreiro não significa se adequar a um só papel religioso, se conformar a uma forma de atuação. A própria estrutura do culto religioso já oferece, logo de partida, duas possibilidades de inserção que exigem experiências religiosas distintas: uma que envolve a incorporação de divindades e outra que a proíbe.

Por outro lado, há uma série de regras e comportamentos aos quais é necessário se conformar para ingressar num terreiro. A mais visível delas diz respeito à hierarquia religiosa. Como já foi mencionado, aprender a respeitá-la, saber quem ocupa qual posição no grupo e qual o tratamento adequado para com tal pessoa foi um processo delicado para os entrevistados. Aqui podemos imaginar que o problema não está diretamente relacionado à classe social, mas sim à familiaridade, ou sua falta, com o universo religioso em questão. Tudo seria um problema de desconhecimento de um código de conduta coletivo, se não fosse por um aspecto diretamente ligado à hierarquia e que tem apresentado certas peculiaridades: a autoridade.

Os cargos distribuídos pelos orixás e os graus de senioridade iniciática constituem a base da autoridade dos membros de um terreiro, cujo ápice encontra-se na figura da mãe ou pai de santo. Estes detêm a última e incontestável palavra sobre tudo, especialmente porque devem traduzir a vontade das divindades (lembremos que só eles de- 
têm a prerrogativa do jogo de búzios no terreiro). A ialorixá e o babalorixá ocupam uma posição particular cuja autoridade agrega: um tanto da legitimidade por cargos reconhecidos publicamente - em tese, pelo menos, devem ter recebido seu decá, o "diploma de pai de santo", nas palavras de baba Dary - um pouco de legitimidade tradicional, pois lembremos que deles é o orixá mais velho da casa que eles iniciaram - o que pode ser um problema em terreiros mais antigos nos quais o líder atual tem que conviver com irmãos mais velhos no santo - e esta senioridade se expressa nos termos "pai” e "mãe"; além da evidente fonte carismática de seu poder conferido pelo próprio axé de seus orixás. Se o "cargo" (que exige reconhecimento público e, portanto, o cumprimento de rituais já prescritos pela tradição, como a metáfora do "diploma" indica) permite uma boa dose de racionalização da transmissão da autoridade no candomblé, o aspecto carismático, porém, a impede no exercício cotidiano dessa mesma autoridade. Aqui encontramos o foco de muitos problemas enfrentados pelas pessoas entrevistadas.

Rosana, por exemplo, não conseguiu se adequar às exigências da hierarquia, não se acostumou a se deitar para tomar a benção a todos os mais velhos, o que fazia somente para pai Dary e nos momentos dos rituais públicos. Ela não admitia que a mandassem fazer algum serviço de limpeza no terreiro ou de preparo para as cerimônias. Seu problema não era com a atividade em si, pois ela preferia limpar os banheiros, e levava produtos por conta própria, a vê-los sujos. O problema, me parece, era receber ordens. Um dia ela se queixou comigo que não era mais uma garota para ficar se agachando o tempo todo para tratar galinhas e que mandassem "alguém mais nova”. Ora, no terreiro era ela só uma abiã, ou seja, uma "mais nova" e deveria obedecer.

Francisco se queixou do ambiente do terreiro e, na verdade, o abandonou três anos depois de ser suspenso, sem ter se confirmado para ogã. No entanto, ele afirma não ter deixado o candomblé, mas sim o terreiro. O motivo que ele alegou para sua saída foi a autori- 
dade suprema do pai de santo para decidir sobre o que pode ou não ser feito, quando e como: "Quando eles querem tudo pode, quando não, nada pode" ${ }^{69}$ Sua queixa pode ser comparada à necessidade de coerência lógica interna, mencionada por Silva (1999, p. 155, grifo do autor) ao analisar os processos de reafricanização e dessincretização que, utilizando-se da literatura acadêmica sobre o candomblé, vêm tornando a religião mais adequada " [...] ao consumo pelo mundo moderno (principalmente por uma clientela interessada também na coerência das tradições de sua religião em termos teológicos e filosóficos)."

É interessante confrontar a crítica de Francisco com a posição de alguém que ocupa exatamente o cargo de autoridade máxima. Pai Robson, que entrou para o candomblé desconhecendo os princípios básicos da religião e enfrentou muitas dificuldades de convívio no terreiro e de aprendizado das regras devido à hierarquia, comenta a respeito da forma de se aprender a religião:

Porque tudo na vida é diferente, você tem a teoria pra depois cê ter a prática. O candomblé é o inverso, ele vai na ordem inversa, você primeiro pratica, pra depois você ter o conhecimento, e o entendimento daquilo que você fez, tipo você é iniciado, você é raspado, mas você só vai entender esses atos todos, quando você começa a iniciar, tipo, sete, oito, nove anos depois. Então você vai praticar uma coisa que você já passou sem o entendimento. O que eu acho que não deveria ser. Mas ai é que tá a parte dos preceitos e fundamentos que, infelizmente, a gente não pode passar. Eaté entendo hoje porque. Porque você só pode, de repente, ter acesso a informações quando pressupõe-se que você teve um amadurecimento pra praticar aquilo que você aprendeu. [...] E fazer de maneira correta, porque se você pega essas informações antes, de maneira inconsequente, de maneira não preparada, você é capaz de começar a praticar esses atos e ao invés de ajudar, você prejudicar.

69 Vale notar que o pai de santo em questão não era do mesmo nível educacional de Francisco, o que pode ter tido alguma influência para que o problema não pudesse ser contornado. 
Há uma tensão na busca por "coerência interna” numa prática religiosa cujas regras dependem da vontade de alguém e podem ser relativizadas a depender do que exige a situação e cuja forma de transmissão do conhecimento está calcada sobre o segredo. Todavia isso não impede a formação de compromissos satisfatórios entre as expectativas pessoais e a prática coletiva, como transparece na fala de Robson. É claro que deve haver certos elementos, sobretudo rituais, quanto aos quais não se admite concessão, mas isto mesmo varia de casa para casa, e quanto às proibições e interdições, estas são na maior parte das vezes negociadas de acordo com as necessidades de cada um e com os orixás. Basta pensar nos períodos de reclusão para iniciação. Além da variação em razão das diferenças de nação, já ouvi casos - não lá em Paripe, mas em terreiros tidos como muito "tradicionais" - em que a reclusão foi reduzida a um mínimo de dias por causa dos compromissos profissionais dos envolvidos.

Para Fábio, essa maleabilidade é um problema. Em sua opinião a Federação Baiana dos Cultos Afro-Brasileiros (FEBACAB) deveria ser mais forte e atuante para poder controlar a legitimidade das práticas dos terreiros. Ele disse sentir falta de uma autoridade central, como a da Igreja Católica, que delimite e oriente os ritos e a teologia da religião como um todo. Nenhum outro entrevistado manifestou posição tão extrema, mas os casos de Fábio e Francisco apontam exatamente em que ponto se espera que a religião seja racionalizada e não o é: em sua fonte de autoridade, com o consequente poder de determinar a conduta dos seguidores.

Aliás, tanto os discursos quanto os atos das pessoas entrevistadas e acompanhadas em campo parecem marcados por esta necessidade de coerência interna, o que se traduz, por um lado, em uma racionalização moralizante da visão sobre a religião - por exemplo, atribuir aos ebós a mesma "lei do retorno" do kardecismo - e, por outro, numa tentativa de adequação estrita a gestos e comportamentos ritualmente adequados: não se chama "orixá" de "santo" nem Olorum de Deus; não existe "pecado", nem o diabo, nem inferno e 
não se participa das "marmotagens" de outros filhos de santo, isto é, de brincadeiras que consistem em imitar o transe, a dança dos outros, as atitudes dos mais velhos. É importante reiterar que esta necessidade de coerência não se concretiza num processo de racionalização efetivamente homogêneo. Embora referentes explicitamente católicos sejam normalmente evitados, outros permanecem atuantes nas explicações oferecidas nas entrevistas e comentários ouvidos em campo. Os mais evidentes consistem no uso de termos do espiritismo kardecista, como mediunidade e crescimento espiritual e na crença de alguns entrevistados em reencarnação, embora esta não possa ser atribuída necessariamente ao universo espírita. Tal ambiguidade, porém, não deve ser interpretada como um "fracasso" da busca por coerência teórica, mas apenas como uma espécie de "lembrete" de que processos reflexivos não são independentes do âmbito da prática, no qual a manutenção de ambiguidades é muito mais a norma do que a exceção. Quanto a isto é interessante relatar duas circunstâncias em que estive presente e que ilustram a natureza do conflito entre racionalização e carisma.

\section{RACIONALIZAÇÃO E MORALIDADE}

Esta busca por uma racionalização - no sentido de sistematização e coerência normativa - tem se mostrado inseparável de uma leitura moralizante da religião. Ou seja, independentemente dos postulados doutrinários exibirem uma distinção ética entre princípios absolutos de bem e mal, as pessoas encontram na religião uma orientação para suas condutas. Não estou afirmando que esta seja uma característica distintiva da classe média com nível superior de escolaridade, uma vez que é muito comum encontramos referências aos limites morais para a ação no discurso de praticamente todos os fiéis com quem mantive contato, mas apenas que, talvez, este seja um âmbito no qual possamos vir a encontrar algumas especificidades. A tão conhecida "lei do retorno" - ou "aqui se faz, aqui se paga" - não seria uma 
formulação que, mesmo escapando aos princípios absolutos, impõe limites para a vontade pessoal?

É muito complicado, é muito cheio de disse me disse, muito cheio de, de ... e outra coisa, o candomblé lhe dá uma... a crença do candomblé lhe dá isso, né? Você não gosta de alguém, 'eu não gosto de fulano, então eu vou aprontar uma com ele', assim. As pessoas fazem muito isso, no candomblé. Não, não reprime, né? Mas na verdade, o... a regulação disso, é, se dá na fé de cada um. Porque, por exemplo, é, eu posso fazer alguma coisa contra você, entendeu? Assim, mas eu, quando eu faço alguma coisa contra você, na verdade eu me esqueço que você também tem alguém, tem alguma energia com você. Você pode me devolver isso depois, cê tá entendendo? Assim, isso é, é tudo muito, as pessoas é que pensam que não é. Mas é tudo muito em pé de igualdade, não é? (Francisco)

Não seria este também o sentido da popular acusação de "fazer o mal" que é sempre dirigida a alguém que se deseja desqualificar? Lara, uma filha de santo que se encaixa em meus critérios, mas que não entrevistei formalmente, uma vez estava furiosa com uma amiga (hoje não mais amiga) que ela havia levado ao terreiro e se tornou abiã. Pegamos uma carona juntas após a sessão de caboclo e Lara reclamava o tempo todo. Acabou dizendo que poderia usar sua força espiritual contra a outra, mas que jamais faria isso, pois tal atitude "diminuiria" seu axé. Em outro momento, ao entrevistar uma filha de santo de classe baixa, esta me garantiu que poderia "jogar no buraco" quem quisesse. Fingi que não entendi e ela repetiu explicitamente que poderia fazer mal a alguém caso desejasse. Perguntei, então, se ela já havia se utilizado desse poder, o que ela negou. Eu quis saber porque e ela deu somente um muxoxo. Na verdade, ela foi a única pessoa com quem falei sobre isso que admitiu abertamente que usaria seu poder com más intenções. No geral, a questão dos ebós como malefício é tida como perigosa para o praticante ou, ao menos para alguns membros de classe média, é relativizada como no discurso de Fábio: 
Vou fazer uma comparação: quando você tá rezando, você tá fazendo um ebó, entendeu? É um preceito que você faz com a mente, com essa energia mental. Então até quando você pensa no orixá e pede alguma coisa, você tá dizendo 'tome um pouquinho dessa energia aqui' pra poder fazer com que tal coisa aconteça. Eu acredito assim. Você tira de algum lugar pra completar em outro. Você tira de um alimento pra completar em uma pessoa que tá com carência daquela energia.[...] Eu achei interessante uma vez, o... o evangélico critica muito o candomblé porque a gente faz ebó, é, faz macumba. É, faz o mal, e não sei o que, pra matar e pra separar e isso aí. Aí, um evangélico tava falando assim: 'Mas eu oro tanto, porque fulano de tal, Jesus ainda vai castigar'. Tá querendo o mal da pessoa! Não é um evangélico? Tá fazendo um ebó pro mal da pessoa. (Fábio)

Evidentemente, a ideia de que os rituais do candomblé podem ser utilizados para qualquer finalidade - e que corresponde ao medo que os não adeptos dizem ter da religião - confere poder aos seus praticantes. Entretanto, é exatamente esse poder que é negado pelas pessoas que entrevistei ou remetido a qualquer uma das religiões, pois o que conta é a "intenção" individual. Pedro contou que suas tias, e mesmo sua avó, haviam tido algum contato com o candomblé como "clientes", mas que tiveram uma péssima experiência e ficaram amedrontadas. Quando pedi mais explicações, ele disse apenas:

Elas quiseram usar a energia do candomblé para [...] a energia, quiseram usar energias negativas. Então, eu acho que existe uma lei universal, independente de religião, que quando você deseja algo de ruim pra uma pessoa aquilo volta sete vezes pra você. Isso é a mesma coisa pra energias positivas.

O babalorixá Dary enfatiza com frequência os três "dogmas" da religião: o segredo, o preceito e o respeito. O segredo, segundo ele, é necessário para que pessoas não preparadas não tenham acesso aos fundamentos do candomblé, o que poderia trazer prejuízos tanto para a religião - devido ao descrédito, ao desprestígio causado por 
ações desastrosas - quanto para os indivíduos envolvidos, que poderiam ser lesados por aqueles que, mal intencionados, detivessem esse conhecimento poderoso. O preceito refere-se não apenas às normas e exigências de comportamento, muito frequentes no candomblé, mas também envolve questões rituais bastante complexas, protegidas pelo segredo. Já o respeito deve ser dirigido tanto às divindades - toda e qualquer uma - quanto aos nossos semelhantes. É interessante notar que o babalorixá não aceita muito bem a ideia de "castigo" do orixá, preferindo expressar-se nos termos de "afastamento" deste, o que deixa seu filho desprotegido e suscetível a diversas contrariedades. Ele próprio tem uma história neste sentido para contar, e quando o faz enfatiza mais sua própria ignorância do que a represália do orixá. Pai Dary costuma dizer que o candomblé é a "religião mais racional" que há, pois não deixa coisa alguma sem explicação, e é ele um dos que enfatizam a necessidade de se "ensinar", educar os filhos de santo que devem estar informados a respeito do sentido dos atos que praticam e não apenas reproduzi-los. Para este babalorixá, a forma "antiga" de aprendizado no candomblé - ver e ouvir sem perguntar - nada mais é do que uma estratégia para a manutenção do poder nas mãos de um grupo restrito.

Em seu processo de iniciação ele enfatiza seu desconhecimento da forma correta de lidar com a divindade, tentando obter do orixá um benefício mundano - sua transferência para Salvador - em troca da feitura. Ao fim ele comenta: "Então uma coisa que a gente aprende, que o orixá lhe atende, o orixá lhe protege, mas só que o orixá não faz trocas comerciais”. Para ele a iniciação tem o caráter profundo de morte e renascimento para uma nova vida e condiz perfeitamente com a concepção já registrada na literatura socioantropológica sobre o candomblé:

Depois que a gente entra no candomblé, que a gente nasce, porque, a iniciação é um renascimento. É uma morte da vida anterior e um nascimento, tanto que você recebe um nome novo, em iorubá. Então, você é batizado, você reaprende a viver, reaprende a conhecer as coisas. Faz parte 
do ato de iniciação. Então, the é mostrado a rua, o tempo, o que é uma cadeira, onde você senta, como você come, tudo isso é re-ensinado, né? Simbolicamente, pra significar um renascimento [...] Inclusive o ato de raspar a cabeça significa isso, né? É a morte pra renascer. Você joga fora tudo o que não prestava pra uma nova vida.

É possível perceber tanto uma tentativa de racionalização teórica quanto uma moralização da conduta dos próprios orixás, em sua maneira de ver a religião: eles nunca farão algo de mal a seus filhos, o comportamento inadequado destes é que pode resultar em seu próprio prejuízo. Mas isto implica numa contraparte: os orixás se tornam mais incompreensíveis uma vez que se afastam do padrão humano de comportamento, seus desígnios tornam-se mais misteriosos. A citação presente na abertura deste texto é uma fala do outro babalorixá, pai Robson, que ressalta o quando foi difícil, para ele próprio, compreender os significados de sua iniciação, hoje expressos em termos de uma "mudança de valores", de “orientação" da própria vida, e de poder auxiliar aos outros no mesmo sentido. Embora estes dois casos sejam de sacerdotes, esse tipo de discurso não se limita a sua categoria. Helena enfatiza que o candomblé, para ela, abriu uma possibilidade de atuação em benefício do próximo, que a sociedade de hoje castra, e destaca o agir como oposição ao "falso moralismo" de outras religiões (principalmente as grandes “religiões éticas”):

Eu acho que tem um, uma porção de aspectos que me interessa mais em relação às outras religiões. Que eu acho que as outras, realmente, 'pregam', do ponto de vista do Decálogo, da escrita e tudo o mais, e na verdade pouco praticam, né? Eu pelo menos vejo. Entre as pessoas que, que frequentam, quer dizer, essa coisa da pessoa que vai pra igreja, que faz isso, que faz aquilo e que, na verdade, maltrata a quem trabalha em casa, maltrata o não sei o que, não é generosa com não sei quem, só pensa em ganância, só pensa nisso, só pensa naquilo, só pensa em corrupção. Então... não vejo muita, lógica, nisso. [...] Que as outras acabam tendo, aqueles rituais. Não, cê tem que acender vela, cê tem que 
ler a Bíblia não sei quantos dias, cê tem que decorar não sei o que lá e tal, mas que isso é uma coisa, coisas, rituais apenas, né? Eu acho que não, eu acho que com o candomblé você tem uma atenção para com você, pra com as outras pessoas, pra com a natureza, pra com o seu cotidiano, contínua, processual, é uma coisa processual. [ênfase na entonação]

A meu ver, nesta reelaboração religiosa não é possível distinguir facilmente a leitura racionalizante da moralizante, ou seja, trata-se de um só processo de apropriação do discurso religioso, que ao mesmo tempo em que o sistematiza, busca sua coerência interna e aproxima-o das exigências morais dos adeptos. Lembremos que para estas pessoas o que as distingue das camadas mais baixas é a “educação" e, como vimos, isto não se refere somente à "cultura" e escolaridade, mas alcança à moral manifestada nas condutas. Assim, temos um foco de desconforto que deve ser tolerado no cotidiano do terreiro. A experiência individual do transe não cria um problema quanto às expectativas de racionalização religiosa. Já a fonte de autoridade sim, principalmente a pouca possibilidade de racionalização da condução da vida cotidiana com base nessa autoridade e a falta de sistematização da moralidade esperada da religião que não encontra meios de se impor ao grupo como um todo. Isto surge como problemático para as pessoas entrevistadas e, deste ponto de vista, há uma apropriação de classe média da religião.

\section{CONCLUSÕES PARCIAIS: CANDOMBLÉ E INDIVIDUALIDADE}

A entrada no candomblé distingue, e por vezes opõe, as pessoas entrevistadas aos demais membros de suas famílias e de sua classe social ampla e heterogênea, de modo semelhante ao que igrejas evangélicas atuais operam como "solvente" das lealdades anteriores à conversão. (PIERUCCI, 2006) Por esse ângulo vemos que especialmente para estas pessoas o ingresso no candomblé apresenta um elemento de individuação. Como todas as famílias vinham de um universo ca- 
tólico e/ou kardecista, com algum contato com a umbanda, pode-se imaginar que qualquer outra religião, como as orientais, teria $\mathrm{o}$ mesmo efeito - e no caso especial de Ernesto, o médico de família comunista, qualquer forma de religiosidade poderia vir a dar na mesma, já que seus familiares são ateus convictos. No entanto, é preciso considerar o forte estigma que ainda pesa sobre o candomblé, mesmo na Salvador do século XXI. Para muitas pessoas de classe média esta religião ainda é "superstição de gente ignorante" ou "feitiçaria", e há pessoas que têm medo sem jamais ter mantido qualquer contanto maior do que ver um grande ebó numa avenida soteropolitana..$^{70}$ Assim, anunciar em casa a iminente iniciação no candomblé não tem o mesmo impacto que comunicar uma conversão ao budismo, por exemplo. Já a entrada para a Igreja Universal do Reino de Deus talvez despertasse rejeição semelhante.

Este ponto ficou claro nas entrevistas. Paulo, como vimos, rompeu com a família paterna aos 14 anos pela religião. Pedro, quando finalmente contou a sua mãe que havia se confirmado, enfrentou não apenas as reclamações como, sobretudo, o receio de que ele viesse a ter que abrir um terreiro (e Pedro é ogã). Fábio e Ana ainda não conseguiram que seus familiares fossem às suas obrigações, exceto a mãe dela. Marta tem uma irmã que passa por problemas espirituais, mas que se recusa a procurar um terreiro devido aos preconceitos que nutre, segundo a entrevistada. Em muitos casos os familiares passaram a uma melhor aceitação, principalmente, por verem como estas pessoas têm trajetórias ordenadas e "normais", embora o pai de Ernesto nunca tenha aceitado conhecer o terreiro e ainda faça brincadeiras acerca da religião do filho. Pelo candomblé estas pessoas se distinguem de seu meio social de origem, ao passo que por causa desta origem distinguem-se da maior parte dos adeptos. Enfrentam

70 Dois exemplos pessoais rápidos: mais de um conhecido me perguntou se eu não tinha medo de pesquisar o candomblé, inclusive colegas da Universidade Federal da Bahia; certa vez abandonei uma consulta após discutir com o médico que insistia que era um contrassenso eu dizer que eu estudava Sociologia da "Religião" e pesquisar uma "superstição". 
abertamente as críticas e preconceitos da parte de familiares, amigos e colegas, declaram sua opção religiosa quando solicitados a fazê-lo, como ao responder o Censo do IBGE, por exemplo, mas ao mesmo tempo criticam o comportamento de outros membros do terreiro que, muitas vezes, é sentido como inadequado e ofensivo.

A menor ênfase na religião como esfera central de interação social - sendo mais um dos meios que se frequenta - coaduna-se com a valorização da ideia de "busca pessoal". Hervieu-Léger salienta a correlação entre o fenômeno da religião como "busca pessoal” na modernidade e o problema da transmissão de tradições culturais de uma geração a outra. Na sociedade moderna as "crises de transmissão" têm obrigado as instâncias de socialização (e a religião é uma delas) a se adequar a novas estratégias de transmissão que logrem ultrapassar as verdadeiras "fraturas culturais" intergeracionais que vêm surgindo. Neste contexto é que a transmissão religiosa tem seu caráter institucional cada vez mais enfraquecido e ganha ênfase a trajetória individual. Essa valorização da religião por opção própria, da busca religiosa pessoal e "autêntica”, combina com o que poderíamos chamar de modernidade psicológica, ou seja, com a ideia de que cada um é um indivíduo que deve se esforçar para manter uma identidade pessoal muito mais forte do que qualquer identidade imposta por uma fonte externa de autoridade, da qual não devemos mais nos conformar. (HERVIEU-LÉGER, 1998, p. 216)

Esta análise pode ser aplicada ao presente caso, no qual a religião "escolhida" é justamente uma que permite a singularização da posição religiosa da pessoa, através de suas relações específicas com divindades e cargos, enquanto oferece mais de uma forma de inserção no grupo enquanto instituição. Mais uma vez, proponho que esta possibilidade de combinações variadas de experiências e posições dentro do grupo religioso pode muito bem constituir um forte atrativo para indivíduos de classe média altamente escolarizados. Esta atração, porém, se dá através de uma apropriação da religião que 
se ressente da impossibilidade de um alto grau de racionalização da autoridade e da conduta da vida, ao passo que impõe certas marcas morais à prática religiosa. Segundo Bourdieu (2003) são exatamente as formas de apropriação de "bens" culturais que expressam um estilo de vida. Mesmo o produto mais técnico é apropriado de acordo com valorações e posicionamentos no espaço social. A religião, porém, não é um "produto" cultural como outro qualquer, pois, como já foi dito, envolve a admissão de uma categoria especial de agentes. Em outras palavras, podemos afirmar que a entrada em certo mundo religioso oferece elementos para o estilo de vida em que é apropriada.

Neste capítulo foi destacado como uma situação de classe favorece determinada apropriação de uma religião. Podemos acentuar as reorientações que esta religião oferecer para a condução da vida cotidiana, mas antes é preciso analisar detidamente em que sentido e em que medida é possível se afirmar que as características acima exploradas permitem e operam a construção de identidades pessoais e, sobretudo, de que forma as trajetórias religiosas analisadas são compreendidas por aqueles que as viveram. É necessário explicitar o que significa "autoidentidade" e suas correlações com as experiências que procurei classificar nestes dois primeiros capítulos. 


\title{
Orixás e projetos: identidades pessoais em trajetórias religiosas
}

\begin{abstract}
Em primeiro lugar vêm as energias que me compõem, eu não sô só Oxum. Eu sô Irene Pacheco, né? Que tem uma família, que me legou virtudes e defeitos. Né? Que tenho, que vivi diversas situações, né? Como a gente já, como lhe coloquei. Eu sô também Oxalá, eu sô também Ogum, sô também Oxóssi, eu sô também Ossaim, Iansã. Ou seja, eu como uma pessoa iniciada, eu tenho uma relação com esses Orixás todos. E esse, desses Orixás, eu não posso ser o Orixá, eu sô a filha do Orixá. A espada é de Oxum, não é de Irene. Irene não tem espada. [risos] Eu sô 'de' Oxum e Ogum. Mas eu sô (de) Oxum e Ogum, eu não sou Ogum. (ênfase na entonação).
\end{abstract}

Ao tentar me explicar de que maneira ela compreende os orixás, Irene produziu um trecho de narrativa que considero sintético e exemplar daquilo que desejo explorar ao discutir a formação de identidades pessoais de membros de classe média no candomblé. Por esta razão, a primeira parte deste capítulo seguirá, em grande medida, a sua explanação, partindo da noção dos orixás como energias da natureza e do indivíduo como portador de uma biografia, passando pela cons- 
trução de uma identidade espiritual e, por fim, tentando explorar as maneiras como podemos compreender a identificação dos filhos com as divindades. Não pretendo oferecer aqui uma revisão bibliográfica dos usos do conceito de identidade pessoal e os esclarecimentos a esse respeito serão feitos na medida em que a exposição os exigir. Na segunda parte alguns pontos serão retomados na discussão sobre os aspectos reflexivos da identidade pessoal - e especialmente a noção de projeto -, a construção narrativa nas entrevistas e os processos pré-reflexivos que se encontram envolvidos nas interações entre o sujeito, o outro e o mundo. No entanto, antes de prosseguir seguindo os passos de Irene, é útil traçar, em breves pinceladas, os contornos do contexto religioso em que atuam estas pessoas.

\section{OPÇÃO RELIGIOSA NUM CONTEXTO PLURAL}

A coexistência de mais de uma instituição religiosa num mesmo grupo social não é uma novidade da contemporaneidade. Por exemplo, na Índia, muitas seitas, como o jainismo e o budismo, competiam com o hinduísmo oficial, pelo menos desde o século VII a.C. (WEBER, 1996, p. 193) Na região do rio Níger, vários cultos de possessão conviveram com o islamismo imperial em diversos períodos, entre os séculos XIII e XVI. (STOLLER, 1989, p. 18) No entanto, atualmente, a religião não apresenta um vínculo extensivo com as sociedades chamadas ocidentais a ponto de permear outras esferas da vida - tais como a jurídica, a econômica ou a intelectual - ou a ponto de que uma única instituição religiosa possa reivindicar legitimamente o monopólio da administração dos bens sagrados. (BRANDÃO, 1994; HERVIEU-LÉGER, 1998; MARIZ; MACHADO, 1998; NEGRÃO, 1997; PIERUCCI, 1998) Isto não significa que as práticas religiosas tenham perdido a importância para imensos grupos humanos, nem que haja uma "crise do sagrado". Mesmo que instituições "tradicionais" como o catolicismo tenham enfrentado diminuição do contingente de adeptos, a vivência religiosa permanece extremamente relevan- 
te para inúmeros indivíduos..$^{71}$ Apenas sua maneira de se vincular às confissões, denominações e cultos ganhou um novo acento: o direito a uma busca espiritual. De acordo com Brandão:

O trânsito tão descrito e discutido entre nós de uma situação social de hegemonia religiosa - em nosso caso a católica pra um campo regido pela lógica e retórica do mercado dos bens simbólicos, não deve ser compreendido apenas como um fenômeno institucional. Ele é também uma questão relativa ao sujeito da fé e, de algum modo, traduz o suposto muito pouco sectário de que, mesmo quando se considera que todas as religiões legítimas do campo visível da fé são ativa ou potencialmente dotadas de verdade, valor, virtude e valia (isto é, 'poder' na concepção popular) cada uma delas divide com as outras parcelas de um mesmo todo de tais atributos. (BRANDÃO, 1994, p. 28, grifo do autor)

Tal suposto de equivalência religiosa - que, evidentemente, é muito mais restrito em grupos como os evangélicos e os neopentecostais - seria o que permite ao sujeito efetuar um "trânsito" por diversas agências religiosas ou recorrer a elas simultaneamente com relativo conforto. ${ }^{72}$ Do ponto de vista individual, o que teria se desfeito seriam tão somente os laços que uniam uma pessoa, desde o fato de seu nascimento, a uma instituição religiosa hegemônica em seu grupo social. Negrão (1997) e Brandão (1994) sustentam que uma das particularidades na constituição do campo religioso brasileiro é sua configuração "pluralista” e "individualista” desde há muito. O primeiro enfatiza o tom mais individual ou, quando muito, familiar ou

71 Prandi (2008) apresenta uma discussão sobre como a importância da adesão religiosa individual não se converte, automaticamente, em influência cultural das instituições religiosas.

72 No sentido de que há várias correntes religiosas coexistindo e que podem ser tidas como complementares, é claro, pois do ponto de vista da história individual esse trânsito pode ser muitas vezes doloroso e motivado por situações altamente perturbadoras. No caso específico do candomblé fica patente a plurivocidade da religião que pode ser qualificada tanto na dinâmica das distinções de classe - sendo ainda objeto de uma valoração fortemente negativa, como "coisa de gente ignorante" - ou no entrecruzamento com o campo acadêmico, no qual ganhou destaque altamente positivo como patrimônio cultural. 
de vizinhança (NEGRÃO, 1997, p. 68) que sempre marcou a vivência religiosa em solo nacional, convergindo com o segundo, quando este reitera a imensa gama de práticas religiosas, desde sempre disponíveis aos sujeitos no Brasil, mesmo que o recurso a virtualmente todas elas não fosse moeda tão corrente outrora como o é hoje.

Então, nada teria mudado para o "sujeito da fé"? Não é bem assim. Em primeiro lugar, como o próprio Brandão (1994, p. 32) salienta: o sujeito de hoje já não se limita mais a lançar mão de todas as religiões de seu campo visível, mantendo-se fiel a uma só delas, mas o faz recorrendo a diversas delas, como um "nômade da fé" cuja fidelidade se volta para sua própria pessoa e não para os grupos religiosos. Em segundo lugar, não apenas a prática religiosa tem um caráter mais individual e menos institucionalizado, como parece haver uma valorização deste caráter, isto é, a busca pessoal pelo sagrado é, ela mesma, valorizada como uma forma de "autenticidade" do sujeito "fiel a si mesmo". (HERVIEU-LÉGER, 1998) Mariz e Machado (1998, p. 360-362) relativizam a perda de ênfase institucional no campo religioso apontando que, ao menos para o caso brasileiro, dois processos ocorrem concomitantemente. Um deles, representado pelas igrejas neopentecostais e pelo Movimento de Renovação Carismática Católica, ganhou impulso nas décadas de 1980 e 1990 do século XX e acentua justamente o vínculo religioso confessional exclusivo, dirigindo uma guerra contra as práticas "demoníacas” de religiões não cristãs. Neste âmbito há um pluralismo religioso confessional, no qual as instituições competem entre si para angariar fiéis e o modelo de carreira religiosa é aquele que leva da posição de "cliente" à de "fiel". Ao mesmo tempo ocorre um movimento de hibridização de práticas e crenças no qual ganha destaque o caráter pessoal das escolhas em matéria de religião. (MARIZ; MACHADO, 1998, p. 371) Por este ângulo, há um enfraquecimento da religiosidade institucional e o fortalecimento de uma subjetivação das crenças e sua combinação com um vocabulário psicológico e bem poderíamos chamá-las de “religiosidades interiorizadas”. Para essas autoras, o segundo mode- 
lo tem maior alcance em países ricos e nas parcelas mais instruídas do chamado "terceiro mundo", ao passo que o primeiro é mais forte entre as camadas mais populares deste último. Com isto, não se nega a existência nem a importância de um processo que coloca o indivíduo como centro ativo da fé e das práticas religiosas, mas apenas se delimita o alcance de tal movimento, da mesma maneira que a hegemonia católica de antigamente deve ser pensada dentro dos limites impostos pela convivência com uma série de outras práticas.

Se ao indivíduo é atribuído o direito de fazer a sua opção religiosa, e ele o faz explorando uma série de contatos com outras pessoas e grupos, a trajetória que ele descreve nesta exploração torna- se ponto crucial para análise da configuração do campo religioso, no mínimo, porque é para este sujeito que se voltam as estratégias de transmissão dos conteúdos religiosos. (HERVIEU-LÉGER, 1998) Assim, para a própria continuidade da instituição, enquanto tal, importa atingir estes sujeitos "errantes" de modo a fixá-los em suas fileiras. Importa saber como torná-los os novos portadores de suas verdades não apenas para que o grupo possa sobreviver, mas para que possa ser vivido como uma "linhagem de crença" (HERVIEU-LÉGER, 1998, p. 216) que retome o passado da instituição em contextos nos quais ele não é a memória coletiva de toda a sociedade, mas sim de um ato fundacional de um de seus muitos grupos. Max Weber (1974b, 1974c) já apontava a significação e o peso de "novos portadores" - principalmente se advindos de camadas sociais heterogêneas - para o desenvolvimento histórico dos grupos religiosos. A análise das marcas típicas que uma camada social imprime a uma religião e vice-versa é uma parte bem conhecida de seus trabalhos sociológicos. Entretanto, não pretendo esgotar a questão das transformações pelas quais o candomblé de Salvador vem passando, em minha opinião, inesgotável e sim analisar o significado de trajetórias religiosas para a conformação de identidades pessoais.

De um modo geral, temos uma situação na qual uma ampla gama de alternativas religiosas se oferece aos indivíduos que podem des- 
crever percursos de um grupo a outro, recorrer a alguns deles simultaneamente ou permanecer vinculados a apenas um deles. Hervieu-Legér (1998) defendeu o uso da noção de trajetória religiosa em contextos de pluralidade, quando várias alternativas são possíveis para um indivíduo, incluindo a possibilidade de negação de qualquer crença religiosa ou metafísica, somadas à ênfase no indivíduo como agente neste percurso. A “crise" institucional de transmissão de valores e conhecimentos de uma geração a outra, identificada pela autora, não diz respeito apenas às igrejas propriamente ditas, mas alcança todas as esferas de socialização, por exemplo, a escola ou mesmo a família. A ideia de fidelidade a si próprio - ao invés de fidelidade às instituições nas quais se toma parte - e da legitimidade de percursos individualizados é vista, então, como um valor "comum", um pressuposto subjacente à maneira como as pessoas veem suas biografias. Desta forma ganha especial destaque a noção de que as pessoas têm o direito à busca espiritual particular.

Diante do que já foi apresentado, podemos inferir que esta concepção de sujeito ativo e "fiel a si mesmo" na descrição de uma trajetória pessoal é condizente com a noção apresentada pelas pessoas entrevistadas tanto no que diz respeito a sua vida profissional quanto religiosa, o que foi correlacionado ao seu habitus escolar de classe média. O presente caso, porém, apresenta uma particularidade: no momento da pesquisa, a maior parte dos entrevistados encontrava-se vinculada a um terreiro de candomblé e não frequentava outras igrejas ou grupos religiosos - exceto outros terreiros. Desse modo, é preciso contrabalançar a ideia de fidelidade exclusivamente a si próprio com a fidelidade a uma comunidade de culto, pois como argumentei, essas pessoas expressaram uma expectativa de exclusivismo religioso. Mais uma vez os casos dissonantes dentre os entrevistados ajudam a manter o equilíbrio da análise. Paulo vai à missa da Igreja Católica de vez em quando, Francisco desistiu de se confirmar no terreiro onde foi suspenso por discordar de algumas decisões da autori- 
dade suprema e Rosana seguiu um caminho desconhecido para mim por não assimilar os comportamentos adequados no terreiro.

Paulo não é um "nômade da fé", ele apenas admite o recurso concomitante a duas práticas religiosas que compõem sua história de vida. Entretanto, quando questionado afirma que sua religião é o candomblé. Rosana é uma nômade com grande variedade de experiências religiosas (tendo passado pelo catolicismo, kardecismo, uma seita indiana não especificada e várias práticas esotéricas) e Francisco encontra-se num momento de indefinição. Todos os demais se encontram ligados exclusivamente aos seus terreiros e mesmo as visitas a outras roças são limitadas - quando comparadas ao trânsito frequente dos adeptos de classe baixa que costumo encontrar nos mais distantes pontos da cidade, a despeito das maiores dificuldades de locomoção -, restringem-se aos terreiros aparentados e se dão, muitas vezes, em companhia de seus babalorixás e ialorixás ou de irmãos de santo.

Com isso quero apenas deixar claro que a fidelidade a si mesmo não elimina a fidelidade a um grupo. O que parece ser de fato relevante é a ideia de que o próprio indivíduo é o agente dessa trajetória e desse exclusivismo que se expressa na noção de "escolha" já destacada. Ou seja, para a maior parte das pessoas entrevistadas, seu percurso religioso individualizado é pensado como uma escolha própria - e neste sentido "fidelidade a si mesmo" - e ao mesmo tempo como vínculo exclusivo ${ }^{73}-\mathrm{e}$, portanto, fidelidade a um grupo. Assim, é por apresentarem uma ênfase na opção pessoal que as identidades pessoais desenvolvidas podem ser analisadas em relação com uma trajetória religiosa, e não por conformarem um "nomadismo da fé". Faz-se necessário, então, uma análise mais detida de como filhos e filhas de santo de classe média compreendem certas noções envolvidas na formação de suas identidades.

73 Mais uma vez, é importante ressaltar que este exclusivismo se refere à participação em grupos religiosos e não conforma totalmente o discurso sobre concepções religiosas que, como vimos, comporta referências a outras religiões, em especial ao espiritismo kardecista. 


\section{O ORIXÁ TEM TRÊS MORADAS: TEORIAS SOBRE DIVINDADES E SERES HUMANOS}

Tratar do mundo do candomblé é tratar de um mundo habitado por pessoas, orixás, erês, caboclos e eguns. O poder de atravessar a divisão entre o mundo da vida humana e o mundo das forças espirituais é próprio das diversas entidades. ${ }^{74}$ Como já mencionei, é preciso ter em mente que para aqueles que participam dessa religião, ou apenas creem em seus efeitos (seja de maneira positiva ou negativa), as entidades são dotadas de agência, são outros com os quais se é obrigado a negociar. (NICOLAU-PARÉS, 1997; SANSI, 2003) Isto ocorre não apenas na vida cotidiana individual, mas também nas interações nos terreiros e não é demais imaginar que até em círculos muito mais amplos numa cidade como Salvador, onde grandes oferendas podem ser encontradas em locais públicos e, reza a lenda, algumas ruas tiveram que ser abertas respeitando as árvores sagradas que lá se encontram, como é o caso do pé de Loko na rua Prof. Aristides Novis. Dessa forma, é interessante começar a discussão sobre identidade pessoal pela concepção dos orixás.

Irene iniciou sua explicação falando das "energias" que a "compõem”. Esta é uma afirmação bastante comum, ao menos entre as pessoas escolarizadas que pesquisei. Ao pedir a várias pessoas (não apenas aquelas entrevistadas formalmente) que me dissessem como compreendiam o que eram os orixás, muitas vezes ouvi a resposta de que eles são energias da natureza. Pai Dary tem uma teoria elaborada acerca dos orixás e esta me foi repetida por vários de seus filhos, ogãs e equedes. Na concepção do babalorixá, os mitos causam alguma confusão ao contar a vida dos deuses como se tivessem sido pessoas que viveram algum dia. Esta confusão se deveria ao fato de que

740 mito "Obatalá separa o Céu da Terra", publicado por Prandi (2001, p. 514) narra exatamente como os humanos foram banidos do Orum devido à quebra de uma interdição. "Exu ganha o poder sobre as encruzilhadas" destaca o papel dessa divindade como "mensageiro", ou melhor, de receptor de oferendas, evidenciando sua função de comunicação entre os dois mundos. (PRANDI, 2001, p. 40) Ver também Juana Santos (1984). 
na África os iniciados perdem seus nomes individuais e passam a ser chamados pelo nome da divindade. Assim, quando se diz que Nanã é mãe de Obaluaiê, por exemplo, isto significa que alguma iniciada de Nanã deve ter sido mãe de algum filho de Obaluaiê que fez algo memorável e ficou na história. Para ele, muita gente toma os mitos ao pé da letra e imagina que houve uma mulher chamada Iemanjá ou um homem chamado Oxalá, por exemplo, e isto não está correto, pois as divindades são energias da natureza e como tal não podem ter nascido nem morrido. São eternos, embora tenham sido criados por Olorum. Desse modo Iemanjá é a própria energia da água marinha, enquanto que Oxum é a energia da água doce, Nanã a energia da lama, Iansã a energia do fogo e do vento, Ossaim a energia das folhas e assim por diante.

Algumas pessoas de outros terreiros expõem uma versão distinta na qual Ajalá, no Orum, faz cabeças de barro a partir dos elementos primordiais que correspondem aos orixás. Quando uma pessoa vai nascer deve escolher uma dessas cabeças, um ori, que comanda seu destino nesta vida, no aiê. Também nesta teoria as pessoas são filhas de determinados orixás por compartilharem com eles do elemento da natureza que é próprio de cada um. Podemos compreender este tipo de explicação como dizendo respeito ao orixá geral (GOLDMAN, 1985) ou a uma espécie de conjunto arquetípico de personalidades que permite uma classificação das pessoas que se acercam do candomblé, embora tal visão tenha sido considerada por alguns dos meus entrevistados como "uma das explicações possíveis" e totalmente recusada por outros, talvez por não levar em conta a qualidade de agentes das divindades. (Ver também, AUGRAS, 1983; SEGATO, 1995; VERGER, 2002b)

A teoria corrente no Torrundê afirma ainda que os orixás também residem na cabeça de seus filhos. Quando cada pessoa nasce, uma das energias naturais predomina nela e ela será filha do orixá correspondente. É dessa forma que as divindades se tornam donas das cabeças de cada ser humano, participando de sua composição na 
forma de energias. As qualidades específicas que podem apresentar formariam, então, “subcategorias”, tal como Iemanjá Ogunté é uma Iemanjá jovem e guerreira, aproximando-se das energias de Ogum. No entanto, isto ainda não é suficiente para que as pessoas tenham uma relação próxima com os deuses e uma vida equilibrada, pois os orixás residem também no ibá, isto é, nos assentamentos individuais onde são colocados elementos materiais da divindade e depositados os alimentos a elas ofertados. Os orixás dos iniciados têm então uma existência individualizada: uma residência no assentamento e um nome próprio revelado ao público ao fim da iniciação. Tal como Goldman (1985) argumentou, a iniciação constrói ao mesmo tempo a singularidade da pessoa e das entidades que a compõem e que são sucessivamente fixadas nos assentos. Esta parece também a concepção de Fabio, um jovem ebomi do Torrundê:

Só que o Ogum, quando incorpora em mim, ele é único. Por que ele é único? Porque ele tá misturado com a energia que é minha, só minha, nesse momento porque essa energia tá presa aqui, quando eu morrer essa energia vai se dissipar e ai tem todo aquele processo evolutivo que eu falei. E o Ogum que incorpora em você, ele é único também. Quando essas energias de Ogum sobem, que elas se dissipam, a minha energia de Ogum vai se misturar com a sua energia de Ogum outra vez porque Ogum é um só. Então, no final das contas, o meu Ogum é o mesmo que o seu, o seu Ogum é o mesmo que o meu.

De fato, considerar os orixás como arquétipos de personalidade significa que a concepção "nativa” opera como uma "categorização”, isto é, como uma forma de classificar pessoas com referência aos conhecimentos sobre o mundo espiritual. É bem verdade que quando começamos a frequentar terreiros de candomblé uma das primeiras preocupações das pessoas com as quais passamos a ter contato é nos atribuir um orixá. Dessa forma, é possível afirmar que ser filho de tal ou qual santo é uma atribuição feita por outros, mas é impossível 
ignorar que ela é negociada a partir daquilo que lhes apresentamos e, mais importante ainda, do jogo de búzios.

Segundo Jenkins (2000, p. 08) a identidade social - saber quem nós somos e quem os outros são - é um pré-requisito para a interação e um momento do processo dialético entre categorização, o momento externamente orientado da identidade social, e autoidentificação, o momento internamente orientado. Ou melhor, trata-se de um processo que atua simultaneamente em direção a si mesmo e aos outros situando-os na relação. (JENKINS, 2002, p. 275) A autodefinição de quem nós somos em parte depende e em parte constrói a categoria que outros nos atribuem e vice-versa. ${ }^{75} \mathrm{O}$ mesmo processo pode ser aplicado para a identidade pessoal. (JENKINS, 2000, p. 10) A ideia é que as identidades, sociais e pessoais, são processos em contínua construção na interação com outros com os quais o "nós” ou o "eu” contrasta, reage, resiste ou se reafirma. De fato é possível interpretar os orixás como um conjunto de conhecimentos estereotipados (PRANDI, 1991, p. 132-140) que permite saber quem é o recém-chegado: "Quando você se atrasou, eu pensei, 'ela é de Oxum'. Não tem gente que se atrase mais, porque roda, roda, roda pra sair, para e volta" (Antônia, também de Oxum, por ocasião de meu atraso para nossa entrevista).

Entretanto é preciso ter em mente que esta relação vai muito além disso: que uma das - apenas uma das - formas de atualização da concepção acerca das divindades é a categorização de outros de acordo com características que os filhos da cada orixá compartilham. Tal categorização é um processo dinâmico e contínuo e se desenvolve nas interações concretas, sendo negociada mais rápida ou lentamente a depender das maiores ou menores evidências de que um indiví-

75 O autor chama atenção também para o fato de que é apenas enquanto sujeitos encarnados (embodied) que podemos comparecer às interações sociais. Isto coloca um certo limite à flexibilidade das categorizações e autoidentificações, uma vez que há sempre uma certa permanência tanto do entorno quando da corporeidade individual, mas esta questão será retomada na última seção. 
duo pertença realmente ao conjunto de filhos de tal divindade. (SEGATO, 1995, p. 49-50) Isto ocorreu com Francisco:

Assim de [...] eu tenho um jeito meio, que eu sei que é meio complicado, assim, as pessoas não gostam muito, é meio arrogante, meio prepotente, assim... E, já que cê me perguntou em relação ao meu orixá pessoal, assim, quando ele [o pai de santo] me disse, né? Que eu fui lá, engraçado, ele não foi a primeira pessoa que disse, outras pessoas já tinham falado... que, olhado pra mim e dito, 'Ah!', inclusive uma pessoa me disse os dois assim, na lata. Mas só que disse: 'cê é de Oxóssi com Oxum'. Não sei, eu não sabia.

Tais “evidências” não constituem uma espécie de "lista de correspondências" entre atributos pessoais e sequer formam um conjunto no sentido próprio do termo. Elas são inferidas com base em relações não sistematizadas, em atos, gestos, "às vezes, é um jeito do olhar”, sem esquecer a importância do oráculo para tal atribuição (e aqui sim, temos uma sistematização). Não há um conjunto estabelecido de características que determine quem é o orixá de alguém, como é o caso dos signos do Zodíaco, dados através da data, horário e local de nascimento. Mesmo a iniciação não fecha totalmente as possibilidades de negociação, como fica claro nos casos traumáticos de "santos errados" de pessoas que foram iniciadas para um orixá e, posteriormente, foram consideradas filhas de outros. Além disso, há as outras divindades que compõem a pessoa e as "qualidades" do orixá, isto é, atributos particulares ligados a sua "biografia": se é uma versão criança, jovem ou velha, guerreira ou maternal, por exemplo. Assim, a atribuição de pertencimento tem que ser feita num processo mais longo. No Torrundê, e em muitos outros terreiros, não se procura saber a qualidade do orixá de frente antes do processo de iniciação e os anos que se passa como abiã são caracterizados por toda uma abertura de possibilidades que serão lentamente negociadas. Segato (1995, p. 52-53) analisou tal processo nos termos de uma fixação inicial em torno do primeiro orixá e posterior flexibilização e abertura para os demais. 
De toda maneira, os orixás podem ser considerados um aspecto de identidade social "dentro" do círculo de pessoas familiarizadas com o candomblé, já que uma categoria deve ser socialmente reconhecida como tal para operar. Como Jenkins (2000) deixa claro, é preciso que esta identidade se construa numa relação de mão dupla com a apropriação da categoria pela pessoa, ou sua negação, nos casos que se procura negociar uma rejeição da categoria atribuída. De uma forma ou outra, a identidade pessoal no candomblé deve levar em conta sua contraparte externamente orientada e o processo de autoidentificação com as divindades ocorre neste "diálogo" com outros. Não é possível ser de candomblé e filho de nenhuma divindade. Entretanto, para "fora" do grupo de adeptos e simpatizantes, tal identificação pode não ter reconhecimento suficiente para operar. Ser "filho de santo", "candomblecista" ou "macumbeiro" - termo pejorativo apropriado e ressignificado de maneira muito interessante, quase cômica, pelos praticantes dessa religião em Salvador - pode ser muito mais efetivo no contato com pessoas de outros círculos religiosos e até mesmo independente de questões de fé, como no caso de negociações com o poder público. ${ }^{76} \mathrm{O}$ pertencimento ao candomblé participa de alguns âmbitos da identidade social de seus membros e é inseparável da constituição de suas identidades pessoais, ou autoidentidades.

Segundo Frigerio (2002), é possível, e preciso distinguir três níveis analíticos: o da identidade pessoal, o da identidade coletiva e o da identidade social, mesmo que nas interações pessoais sejam sempre inter-relacionados. A distinção é possível porque em cada um dos níveis operam mecanismos de atualização diferentes, sobre os quais se constroem os esforços de transformação das identidades de pessoas que se vinculam a movimentos sociais ou a grupos religiosos. Assim, enquanto as identidades sociais dizem respeito a classificações socialmente reconhecidas que enquadram pessoas em certas categorias ou grupos - e podem ser assumidas como integrantes da identidade

76 Para uma análise de relações semelhantes na Argentina, ver Frigerio (2003). 
pessoal ou rejeitadas - como ser "de santo", as identidades coletivas são forjadas em torno de um sentimento de "nós" que se dirige para ações coletivas, por exemplo, embarcar numa luta judicial pelo respeito religioso. Já as identidades pessoais voltam-se para a questão de quem "eu sou" no mundo social e, desse modo, exigem um esforço reflexivo (embora o ultrapassem) de incorporação e atualização de valores e ideias do(s) grupo(s) ao(s) qual(is) se admite pertencer. O autor enfatiza a necessidade de se levar em conta que estes três níveis analíticos estão sempre imbricados na interação social, locus do desenrolar das identidades, situações nas quais o self se torna acessível através das identidades tipificadas que apresenta ou que lhe são atribuídas por outros.

Para as pessoas que acompanhei, passar a ser de candomblé oferece um contraste com os membros da família, amigos e colegas de trabalho, os círculos com os quais mantêm interações mais frequentes e que, em geral, são católicos “formais" - não praticantes - ou espíritas kardecistas. Como membros de uma classe intermediária, com variados estilos de vida, escolaridade, profissões e padrões de consumo, ou seja, que não oferece uma arena de identificação coletiva - embora possa e seja assumida enquanto identidade social - essas pessoas encontram no candomblé um grupo com identidade relativamente mais efetiva ${ }^{77}$ e cujo objetivo, nesse aspecto, é gerar um processo de identificação por parte dos adeptos. ${ }^{78}$ Nesse sentido, ser "de candomblé" ou "de santo" é um aspecto da identidade social que, assumido pela autoidentidade, permite ao indivíduo traçar uma distin-

77 O conceito de classe social não foi forjado de modo a dar conta, por si só, de processos identitários. Referindo-se a um estado de correlação de forças (ou poder) e não a um grupo de pessoas, não é suficiente para tratar de elementos da identificação entre elas que podem formar um senso de coletividade. Como vimos, certas percepções de distinções (que nesta pesquisa remetem à classe) são importantes para a autoidentidade e para a categorização. No entanto, apenas se tornam fortes o suficiente para fazer emergir um "nós" distinto do "eles" em interações concretas.

78 Mesmo que esta identificação fique restrita ao terreiro ao qual se pertence e seus aparentados. Para grupos religiosos como organizações de transformação da identidade, ver Frigerio (2002). 
ção entre si e os demais com quem convive cotidianamente. Permite também uma forma de identificação com pessoas mais distantes, cujos modos de vida podem ser muito diferentes, mas com as quais se compartilha uma religião, de maneira geral, e com seu grupo de culto de modo particular.

Esta identificação possibilitada pela religião, no entanto, não permite uma aproximação homogênea com todo o grupo de culto. As distinções de classe são fortemente sentidas, mesmo que com o passar do tempo, a convivência com pessoas diversas passe a ser positivamente avaliada. Um outro "nós” emerge dentro do "nós” de um terreiro e várias formas de contraste são enfatizadas a depender da extensão do grupo que se toma por objeto de análise, como um conjunto de casas aparentadas, uma nação ou a própria religião.

Frigerio (2002) enfatiza ainda que uma pessoa pode adotar uma identidade social religiosa sem que tenha passado por mudanças significativas em sua identidade pessoal, como um adepto recente que ainda não incorporou profundamente as concepções do grupo, por exemplo. O contrário também pode ocorrer, como nos casos das religiões estigmatizadas que podem ser extremamente importantes para a autoidentidade dos sujeitos, mas não reivindicadas como elementos relevantes de sua identidade social, ou em situações extremas, podem ser escamoteadas nas interações. É o caso, muito comum, de pessoas de candomblé que se apresentam como católicas. ${ }^{79}$ Já foi exposto que, neste ponto em particular, as pessoas de classe média parecem ser bastante reativas aos preconceitos contra o candomblé, expondo publicamente sua adesão religiosa como um elemento de suas identidades com bastante frequência, embora nem sempre. Como argumenta o autor, podemos pensar numa estrutura de compromissos identitários cujos aspectos podem ser postos em relevo a depender do contexto. Dessa forma, há uma identificação com pessoas de origens sociais variadas pelo aspecto religioso, mas há uma

9 É preciso considerar, porém, que pode não se tratar de um escamoteamento deliberado, mas sim de uma noção de que o catolicismo é a religião e o candomblé é o "axé". 
distinção entre elas pelos aspectos de classe e cada um deles pode sobressair a depender do tópico da entrevista ou do que está em questão nas interações concretas.

Ana pode ser descrita como uma jovem, casada, mãe, branca, auxiliar de Recursos Humanos, de classe média, iaô, filha de Iansã, entre inúmeras outras classificações. Ela mesma pode adotar todas estas que mencionei e mais uma série de outras. Entretanto, contou-me que no seu atual emprego ainda não revelou que é de candomblé. Não se viu numa situação em que fosse abertamente questionada e no seu trabalho anterior sentiu-se discriminada quando, ao sair da reclusão no terreiro, teve que ir trabalhar durante alguns meses vestida de branco, com os cabelos raspados e a cabeça coberta. Na ocasião ela foi transferida para uma função na qual não tivesse que atender fornecedores e, com isso, para outro escritório, muito mais distante de sua residência. $\mathrm{O}$ seu caso pode ser tomado como um exemplo de uma pessoa que tem uma identidade pessoal fortemente marcada pela religião, mas que a depender do contexto de interação pode apresentar outros aspectos mais valorizados de sua identidade social. Já outros entrevistados, como pai Dary ou os ogãs Pedro e João Alfredo, contaram que se identificam publicamente como membros de candomblé sempre que o tema religião surge, mesmo já tendo passado por alguns constrangimentos, menos ameaçadores do que o experimentado por Ana.

Esta postura contrasta com aquela observada entre adeptos de classe mais baixa, ao menos em Salvador. Tenho observado, nos terreiros que frequentei, que é muito comum que não se assuma publicamente ser de candomblé. Ao entrevistar dona Berta para um projeto no qual colaborei, ${ }^{80}$ perguntei sua religião. Mesmo vestida com as roupas do candomblé, ela respondeu "católica". Eu ainda perguntei mais uma vez e ela completou: “é, tem o axé também”. No terreiro de pai Robson observei um de seus ogãs, um arquiteto de classe média, discutir com uma filha de santo já de certa idade, pelo fato de que ela

80 Trata-se do projeto já referido, coordenado pela prof ${ }^{a}$. dr ${ }^{a}$. Miriam Rabelo. 
não gostava de dizer que pertencia a um terreiro e sequer comentar as datas das obrigações em casa. Durante a discussão ele se irritou bastante quando ela disse "Deus me livre de meu filho querer vir pro candomblé." Este tipo de atitude é bastante frequente, sobretudo, entre os adeptos de camadas menos escolarizadas e menos favorecidas economicamente para quem fazer o santo pode ser uma necessidade e não uma opção. Assumir publicamente o pertencimento a um terreiro, ou à "religião dos orixás" - termo preferido por alguns - é uma postura usualmente encontrada entre militantes religiosos e/ ou de movimentos negros. Os profissionais de classe média parecem compartilhar com eles a ideia de que é preciso valorizar sua opção religiosa, mesmo que para eles não se trate de uma militância sistematizada.

Dessa forma, o pertencimento ao candomblé afeta a identidade nos vários níveis analíticos propostos por Frigerio (2002, 2003), embora atue de maneira diversa em cada um. Para os membros da classe média com cultura escolar, em geral, torna-se uma faceta da identidade social assumida publicamente, mas que não escapa, nem pode escapar, às variações situacionais. No caso de uma identidade coletiva, como argumentou o autor para a Argentina, nem sempre o candomblé opera na formação de um senso de "nós" capaz de mobilizar para uma ação coletiva. Segue-se aí a lógica de filiação às casas - o "nós" de tal terreiro - e de parentesco ou rivalidade entre elas, embora ataques por parte de outros grupos, especialmente da Igreja Universal do Reino de Deus, tenham sido bastante eficazes na mobilização dos membros de candomblé em Salvador nos últimos anos e ações bem sucedidas de alguns terreiros na esfera pública possam ser comemoradas em outros não aparentados, como no caso da vitória judicial dos herdeiros de mãe Gilda, falecida em janeiro de 2000, após agressões praticadas por membros da referida igreja contra seu terreiro de candomblé. No Torrundê, o caso foi acompanhado com atenção por várias pessoas e notícias de jornal foram pregadas no mural interno quando os familiares da ialorixá ganharam a causa. 
No nível da identidade pessoal é preciso ter sempre em mente a imbricação entre todos eles e que ser filho de um determinado orixá significa ser feito a partir dos mesmos elementos da natureza que ele. É uma afirmação sobre a existência de pessoas e divindades e não apenas uma correspondência entre atributos. Como foi mencionado mais acima, a própria concepção dos orixás os apresenta ao mesmo tempo como energias cósmicas, impessoais e altamente individualizadas, capazes de agir no mundo por conta própria. Assim, a relação entre os filhos e as divindades é marcada, simultaneamente, pelo mais genérico - bem expresso na ideia de que todo ser humano tem orixá, até os santos católicos ${ }^{81}$ - e pelo mais particular, manifesto na individualidade do orixá da cabeça de cada um e nos cuidados que se deve dedicar individualmente ao assentamento de suas entidades.

É preciso, então, analisar as direções que tomam os processos de autoidentificação nas interações sociais para colocá-los em relação com noções bem difundidas sobre a pessoa. Confrontar as ideias expressas entre os membros do Torrundê e demais entrevistados com as proposições acerca da ênfase na noção de biografia e de reflexividade operantes na contemporaneidade pode ser extremamente frutífero para uma compreensão mais nuançada da formação das autoidentidades entre membros de classe média no candomblé.

\section{IDENTIDADE PESSOAL E BIOGRAFIAS}

$\mathrm{Na}$ fala de Irene ela nos diz que além das energias que a constituem, ela é Irene Pacheco, uma pessoa que viveu diversas situações, que vem de uma família que ela considera como fonte de uma certa herança em "virtudes e defeitos". Mais uma vez surge a questão do reconhe-

81 Esta é a base da interessante explicação de pai Dary para o sincretismo religioso com o catolicismo. Como toda pessoa tem orixá, aquelas que se tornaram santas também tinham os seus. Isto fez com que a influência das divindades em suas vidas e modo de ser tenham marcado sua história pessoal. Tais características, quando muito marcantes, permaneceram evidentes em suas hagiografias. A partir disso as pessoas puderam fazer associações entre os santos e os orixás. Assim sendo, Santa Bárbara é tida como filha de lansã, mas não a própria divindade. 
cimento da força de certas circunstâncias, das relações familiares como ficou claro nas escolhas profissionais de Ernesto e Marta - e até mesmo dos orixás. Ao mesmo tempo, emerge uma centralidade da pessoa como portadora de um conjunto de atributos e agente em uma série de eventos que a fazem única. É interessante observar que Irene diz "em primeiro lugar vêm as energias que me compõem" e logo a seguir enuncia seu nome próprio e a "herança” familiar, parecendo hesitar entre definir-se primeiro com relação aos orixás ou com relação a sua biografia.

Velho (1981), ao estudar o estilo de vida das camadas médias cariocas, apontou a importância da escolarização e, sobretudo, da incorporação de "teorias científicas" sobre o indivíduo, de cunho psicológico e psicanalítico, na formação das identidades pessoais de membros dessas camadas. Tais concepções estariam na base dos projetos "biográficos" aos quais se lançariam os sujeitos. Em outros termos, uma característica distintiva do estilo de vida dessas camadas médias seria uma concepção de si mesmo orientada pela apropriação de certos conceitos que enfatizam a reflexividade do processo de autoidentificação, conferindo-lhe características de um "projeto", ou seja, de um esforço consciente para dar coerência à diversidade de papéis exercidos em diferentes contextos culturalmente delimitados. (VELHO, 1981, p. 31-32) No caso que apresento, é possível perceber a relevância de ideias como história pessoal e biografia, na constituição da identidade pessoal como transparece na fala de Irene que abre este capítulo, embora eu questione, como veremos mais adiante, a preponderância da orientação reflexiva nos processos identitários.

Nos capítulos anteriores argumentei que as possibilidades de singularização frente à família e à classe social heterogênea e de individualização religiosa abertas pelo candomblé podem ser alguns dos atrativos dessa religião sobre as pessoas pesquisadas. Tal como nos argumentos de Velho (1981) e de Giddens (1991), essas pessoas compreendem-se como o "centro ativo" de suas histórias e, mais ainda, como capazes de optar e de eleger caminhos. Na verdade, trata-se de 
uma noção bastante corrente hoje em dia. Para Vera Felicidade de A. Campos, psicóloga, Oni Kowé do Ilê Axé Opô Afonjá, por exemplo, o horror da escravidão era a dissolução da individualidade do negro africano:

Em séculos passados, o africano chegou ao Brasil como escravo, pior que isto, como mercadoria para ser vendida. Era o carregamento valioso e necessário para o desenvolvimento agrícola do Brasil colônia. Trazido como coisa, tinha apenas peso, tamanho, força e uma cor que tudo identificava e justificava - era o preto. Desconsiderada a individualidade, sumia qualquer aspecto cultural, religioso. Sumia, pois estava encoberto pela não aceitação do vendedor/comprador. Não apareciam individualidades, não apareciam seres humanos. Apareciam escravos, pretos, sem nome, sem origem, sem cultura, sem religião. (CAMPOS, 2000, p. 167, grifo nosso)

Ainda segundo a autora, um dos grandes méritos de mãe Stella - atual ialorixá do Ilê Axé Opô Afonjá - é ser “[...] responsável pela dinamização individualizante de uma dimensão cultural [...]”. (CAMPOS, 2000, p. 170) Sua ênfase na importância da individualidade dilui a força de sua reiteração constante de que as atitudes se estruturam na relação com o outro. Não se trata aqui de criticar as concepções que os membros do referido terreiro expressam nos textos que publicam, mas apenas de apontar para a amplitude da difusão de conceitos das teorias psicológicas dentro e fora dos terreiros. Vera Felicidade de A. Campos participa de uma das casas religiosas que mais têm contribuído para a publicação de literatura dos próprios membros da religião. Assim, seu discurso ganha largo alcance e torna-se de fácil acesso, não sendo apenas um exemplo de certas concepções, mas participando de sua própria construção.

Como argumentou Jenkins (2000, 2002), quem eu penso que sou é um processo que corre simultaneamente em direção ao outro e ao próprio eu e que se efetiva nas relações sociais. Que estas relações sejam estruturantes de atitudes e comportamentos não discordo, apenas coloco em questão que um de seus polos constitua necessa- 
riamente uma individualidade, no sentido de uma entidade discreta portadora de atributos, como no texto da Oni Kowé. Mauss (2003a) enfatizou belamente que ter um nome, uma origem, uma religião não faz de alguém, necessariamente, um indivíduo. Pode fazer exatamente o contrário, uma persona a desempenhar um papel, uma pessoa que não se constitui como centro moral da ação.

Contudo, as pessoas que entrevistei parecem concordar, de maneira geral, com a autora citada. Para elas, ter um nome, uma origem, uma história, não as faz personagens de um enredo tramado em relações sociais para além do seu alcance. Elas não desempenham um papel no qual foram inseridas por relações de parentesco ou pela tradição. Elas desempenham vários papéis a depender da situação e, muitos deles, "escolhidos" por elas. Além disso, mesmo ao desempenhar um "papel” é empenhando sua singularidade que elas o fazem. Marta não representa a jornalista, mas é jornalista ao modo de Marta. Pai Dary no barracão não é o pai de santo, mas sim um babalorixá que comanda a sua roça. Assim como, quando incorporado, ele não se torna Obaluaiê, mas um Obaluaiê Ajagun que tem um nome próprio e uma morada em seu ibá, embora seja sempre conectado à energia geral de Obaluaiê. Quer dizer, a individualidade é uma questão relevante para estas pessoas, mesmo quando exercem papéis, mesmo quando se inserem em processos que têm uma face "desindividualizante" como a iniciação, uma vez que a própria concepção das divindades apresenta caráter individualizado:

Porque veja bem, o recolhimento, ele é, na realidade, preparar a matéria, tá? 'Você' é que tem que estar preparada pra essa nova vida que você vai ter, a nivel de espiritualidade. Cabe a cada um fazer ou não fazer. Cê pode passar vinte e um dias recolhida e você não mudar interiormente. Isso, essa mudança, é individual. Tem pessoas que podem levar um ano recolhida, vai sair dali e vai ser do mesmo jeito, porque as mudanças são individuais. Os atos que são feitos, são ritualísticos sim, precisam ser feitos, é o ato do renascer, né? É muito bonito, ótimo, maravilha, mas o re- 
nascer é uma questão do querer. (Pai Robson, ênfase na entonação)

Aqui a mesma temática que havia surgido a respeito da opção pelo candomblé face à família, ressurge com uma profundidade maior. Não se trata apenas de seguir um caminho singular, mas de ser agente da própria transformação pessoal. Se a noção de individualidade é tão importante no contexto aqui explorado, cabe analisá-la com maiores detalhes. Imbricada nas ênfases postas pelos pesquisados está uma expectativa de reflexividade no processo identitário. Não somente aquela inevitável, envolvida em toda operação de distinção e contraste, em toda interação na qual o "eu” aparece também refletido nos olhos do “outro”. Trata-se de uma disposição à apropriação reflexiva do próprio percurso e das próprias características, procurando desvendar seus sentidos. Tal como propôs Giddens (1991), as identidades pessoais ganharam características de um "projeto" no qual o sujeito se vê ativamente engajado. Segundo o autor, a amplitude alcançada pela reflexividade - que da esfera institucional alcançou a intimidade - é uma das características da contemporaneidade, chamada por ele de alta modernidade. Isto significa que a revisão constante das formas de ação em organizações e instituições passou a incorporar uma série de conhecimentos especializados acerca da própria ação, abarcando até mesmo a noção de self. Na vida cotidiana, isto se reflete na ideia de que "Cada um de nós não apenas 'tem', mas vive uma biografia reflexivamente organizada em termos de fluxos de informações, sociais e psicológicas, sobre possíveis modos de viver”. (GIDDENS, 1991, p. 14, grifo do autor) Sua difusão conta com o largo impulso da literatura de autoajuda que, apropriando-se dos conhecimentos "peritos" da psicologia, psicanálise e teorias sociais, torna-se o veículo de suas concepções para amplas parcelas da população. Estas passam a dispor de um vocabulário técnico-científico para retomar o próprio passado, expressar suas experiências e, assim, orientar sua ação. Dessa forma, as identidades pessoais na alta modernidade constituem-se num processo contínuo de reflexão 
acerca do próprio eu - tornando-se uma disposição permanente que incorpora conhecimentos objetivados acerca de quem é o ser humano e o sujeito da ação social.

Jenkins (2000) considera um exagero de Giddens tomar a reflexividade como uma das características distintivas da contemporaneidade, apontando que esta pode ser encontrada em outros tempos e culturas. No entanto, é sintomático o interesse despertado por biografias e diários, bem como a proliferação dos já referidos livros de autoajuda e oficinas do mesmo gênero, cujo objetivo é fornecer ferramentas ao público para dirigir suas ações, pensar sobre si mesmo, avaliar suas relações com outros, lançar-se em projetos. O esforço de auto-objetivação, de tomar a si mesmo como objeto de reflexão, não é exclusivo das grandes sociedades ocidentais atuais, mas o que Giddens (1991) acentua é que isto se dá, na alta modernidade, através da incorporação de conceitos e métodos técnico-científicos amplamente difundidos e que se torna uma disposição permanente. Com a vulgarização de noções como ego, self, indivíduo, torna-se possível ao sujeito empírico realizar tal retomada vendo a si próprio como centro ativo desse processo através de um vocabulário específico. Em outros termos, pode-se dizer que tal noção de indivíduo é um dos elementos do habitus incorporado em tais pessoas, é um dos valores que orienta a sua ação, ou sua forma de engajamento no mundo. É o que Velho (1981) propôs para a análise das identidades pessoais das camadas médias cariocas, levando em conta a importância da escolarização em seus estilos de vida. Em parte, coincide com o que foi apontado por Mariz e Machado (1998) acerca da "hibridização" de práticas religiosas católicas carismáticas com práticas psicanalíticas - regressão à vida intrauterina - e de outras religiões - budismo e kardecismo - entre pessoas com formação universitária em Belo Horizonte.

A noção de identidade pessoal como projeto, proposta por Giddens, aponta também para outra característica relevante já referida pelos demais autores: as identidades são processos contínuos, dos 
quais podem fazer parte as trajetórias religiosas. Nos contextos das grandes cidades contemporâneas, estas podem, então, ser analisadas como projetos. O trânsito de pessoas por diversos grupos religiosos pode ser considerado como uma revisão crônica de si mesmo - e de suas experiências e expectativas - que incorpora os conhecimentos específicos adquiridos e cuja ênfase recai no indivíduo como polo ativo. Em sua exposição encontra-se também a ideia de fidelidade a si próprio, referida por Hervieu-Léger (1998, p. 218), para quem as identidades religiosas devem ser analisadas através das experiências individuais e são o resultado precário, e sempre passível de revisão, de trajetórias de identificação que se realizam em processos longos. O que é apontado como característico da contemporaneidade é a ideia de que o indivíduo pode e deve escolher as normas e valores sob os quais viver. ${ }^{82}$ Neste sentido é que deve ser compreendido o termo "trajetórias de autoidentificação" tantas vezes utilizado neste trabalho como uma ênfase no aspecto processual das identidades e em sua dimensão internamente orientada. (JENKINS, 2000)

Mais uma vez é importante deixar claro que, embora concepções em comum possam ser encontradas, no caso de que trato as pessoas efetivaram um vínculo religioso exclusivo e atribuem importância a ele. Suas trajetórias são distintas daquelas que permanecem abertas, como nos casos analisados por Mariz e Machado (1998), uma vez que elas se encontram, no momento, fixadas nas fileiras de grupos bem definidos e valorizam o exclusivismo religioso. Como já foi mencionado, isto não finaliza a trajetória religiosa, mas esta deve prosseguir na estrutura hierárquica de um terreiro de candomblé.

82 Mais adiante esta concepção será nuançada. Tal como Mariz e Machado (1998) procuraram mostrar para a perda de relevância das instituições religiosas, não é possível aqui levar às últimas consequências a ideia de autonomia do indivíduo porque isto pressupõe uma dissociação entre o sujeito da ação e seu mundo cultural que não pode ser sustentada. Normas e valores não podem ser eleitos livremente pelo simples fato de que a eleição precisa operar sobre alguma base e esta é dada num mundo compartilhado. 0 que se pode argumentar é que a as grandes cidades contemporâneas abrigam uma série de "submundos" culturais que oferecem bases diversas. (VELHO, 1981) 
De toda forma, as características apresentadas acima permitem colocar mais uma interpretação desta religião afro-brasileira para as pessoas em questão. O candomblé foi muitas vezes mencionado como uma "fonte de autoconhecimento". Com isto, é possível argumentar que os conhecimentos "peritos" religiosos podem ser incorporados a esse processo de revisão crônica da própria vida, a um aprendizado de quem se é, de como lidar consigo mesmo e com os outros. Pai Dary atribui ao conhecimento de seu orixá e a sua relação pessoal com ele o fato de ter se tornado uma pessoa mais paciente, mais tolerante com os outros, pois segundo ele, quando era jovem, era muito estouvado e explosivo. O convívio com a qualidade jovem e guerreira de Obaluaiê lhe permitiu trabalhar o lado impaciente e desenvolver mais o lado emotivo e carinhoso. De forma semelhante, Antônia, tendo o conhecimento de que é filha de Iansã, vai "puxando mais elementos da água”, aprendendo a ser mais terna:

[...] a maioria das vezes que eu me vejo entrando na coisa da paixão, que é uma coisa de Iansã, eu chamo por Iemanjá rapidinho, eu digo, 'ô, meu Deus, jogue água, pela Iemanjá, tome aí, isso é uma coisa pra você, não pra Iansã, fique aqui', eu digo mesmo, mentalizo.

Assim, conhecer os orixás que compõem sua cabeça, as relações entre eles e as outras entidades, passa a fazer parte não apenas de uma classificação estereotipada do outro, mas de uma reflexão acerca de si mesmo. De fato, isto tem se mostrado relevante para os entrevistados, sobretudo, no que diz respeito à reinterpretação de seu passado anterior ao ingresso no terreiro. "A vida toda eu fui de Oxum”, "eu sempre fui assim, mas não entendia” e variadas formas de referência a fatos não explicados da infância, que são reavaliados como a presença dos orixás naquele passado em que eles eram desconhecidos. O passado pessoal é reaberto e reinterpretado na chave da religião. Mesmo a família pode ser envolvida neste processo, à revelia, nos casos em que são identificados orixás herdados ou mesmo um vínculo 
“ancestral” com o candomblé. ${ }^{33}$ Nos termos de Giddens (1991) os conhecimentos religiosos tornam-se um eixo de organização reflexiva das biografias. No entanto, como vimos, é preciso manter um certo equilíbrio entre a ação dos indivíduos e dos orixás. Como argumentou Segato (1995, p. 25):

Ao se abordar esses discursos afro-brasileiros à luz das perguntas fundamentais que os autores que acabo de citar formularam, conclui-se, como mostrarei, que a ideia indivíduo, como identidade separada do seu personagem social, está presente. Porém, a individualidade é ancorada numa referência - o orixá 'dono da cabeça' da pessoa em questão situada num espaço descrito como exterior e não num espaço de interioridade.

Reconhecer a presença dos orixás “desde sempre" e a força de sua vontade não elimina a agência individual, como já foi dito. A própria concepção de destino particular do candomblé não entra em confronto direto com a noção de projeto. Como escreveu Vianna Santos

Restaurar o equilíbrio entre essas duas partes [cabeça física e cabeça espiritual] é o objetivo dos ritos, em especial o 'rito do bori', entretanto, o que não foi sancionado pelo ori não poderá ser feito pelo orixá, pois o poder da individualidade proporciona a condição de que tudo o que não for desejo do ori de uma pessoa não poderá ser alterado por nenhuma divindade, daí ser muito comum entre o povo-de-santo a expressão 'converse com seu ori' . [...] Embora ayamó (destino) possa ser mudado por kadará (circunstância), a pessoa deve

83 É importante notar que tal herança não me foi explicada nos termos de uma referência que chegue à África, nem ao orixá como ancestral mítico, tampouco como forma de relação com baba Egun. As histórias que apresentaram tal ponto diziam respeito a uma "maldição" jogada contra algumas gerações da família, como no caso de Pedro, ou de uma suspeita de "herança" do orixá de uma ascendente ligada ao candomblé, como no caso de Marta. Tal relação pode mesmo surgir como algo que era desconhecido pelos próprios parentes e que, por isso mesmo trouxe prejuízos à sua vida. Para uma descrição sucinta do culto a baba Egun na llha de Itaparica e em Salvador, ver Braga (1988) e Santos (1975) apresenta uma sistematização das concepções metafísicas presentes no candomblé. 
trabalhar com afinco para essas possíveis mudanças [...]. (SANTOS, M., 2003, p. 63-64, grifo do autor)

Mais uma vez é enfatizada a necessidade de equilíbrio entre condicionamentos e ação individual. "Trabalhar com afinco", sobretudo através dos ritos religiosos e obediência aos preceitos, é algo que tem o poder de mudar o destino decidido antes do nascimento. Até que ponto esta concepção é uma herança africana ou até que ponto a própria noção ocidental foi apropriada pela religião é uma questão impossível de se decidir. O fato é que o candomblé é uma religião brasileira, desenvolvida no seio desta sociedade e, não sendo uma ilha isolada, não poderia estar imune às concepções correntes. Além disso, o autoconhecimento mencionado também diz respeito ao presente e ao futuro. Apreender a si mesmo como filho de um dado orixá possibilita uma compreensão do próprio jeito, das próprias atitudes por um novo ângulo. Dessa forma, os atos individuais podem adquirir nova significação e podem ser geradas orientações para a ação.

Embora a análise de Giddens (1991) permita uma reflexão acerca do caráter dos processos de autoidentificação como um projeto reflexivamente orientado que possibilita a incorporação de certos conjuntos de conhecimento acerca do sujeito, o acento posto pelo autor recai sobre a interação do sujeito consigo mesmo e com tais conhecimentos. Se permanecermos neste nível de interpretação, as divindades do candomblé aparecem como tipos que possibilitam a avaliação de características e do comportamento próprio e de outros. Isto não é tudo, porém, quando o esforço é por compreender a ação de sujeitos em seu mundo - já que o sentido desta não se dá numa suposta vida interior e sim no contexto das relações com outros.

A ênfase de Giddens (1991) em mecanismos abstratos - cuja validez pretendida é independe do contexto de aplicação, tal como as proposições científicas - como mediadores na alta modernidade termina por deslocar o papel das interações sociais na análise, que como vimos, outros autores convergem em apontar como locus de processos identitários. Ou seja, não apenas o que se sabe sobre as divindades 
e os conceitos compartilhados são relevantes, mas também - e principalmente - as relações que se desenvolvem em situações concretas. Assim, quando se passa a fazer parte de um terreiro, os papéis desempenhados, as atividades que se executa e como se é visto pelos outros são pontos que não podem ser ignorados na tentativa de compreender como se desenrolam os processos de autoidentificação de pessoas de classe média com o candomblé. Não adianta nada, por exemplo, uma pessoa ver a si mesma como filha de um dado orixá se sua experiência não for reconhecida pelos demais.

No caso dos terreiros de candomblé, essa experiência tem que ser, além de tudo, exposta e reconhecida publicamente. Isto é uma parte importante do que se passa nas obrigações e nas saídas de iaô: ${ }^{84}$ a exibição e confirmação para além do círculo de um terreiro - e de seus aparentados - de quem aquelas pessoas estão se tornando. Em se tratando de uma forma de engajamento interacional, novamente, é imprescindível considerar os “outros” existentes nos terreiros. Já vimos um pouco das relações com outros humanos - em muito marcadas por um esforço de manter certa distância. É preciso considerar, então, os modos de relação com o outro sagrado.

\section{IDENTIDADE ESPIRITUAL}

Irene prosseguiu explicando que além da energia de Oxum, ela também é composta pelas de Oxalá, Iansã, Ossaim, Oxóssi. Mencionou também a espada de Oxum e que Ogum é seu juntó, o que permite imaginar que se trata de Oxum Apará, uma das qualidades desse orixá. Afirmações como a sua são muito comuns e fazem parte da explicação das diferenças e idiossincrasias entre filhos do mesmo santo.

84 Até mesmo os "clientes" dos ebós têm que se expor a um certo público, uma vez que estes não são feitos sem o auxílio de alguns iaôs, ogãs e equedes. Sempre haverá alguém para cantar, bater palmas, ajudar a preparar e a limpar na execução do "serviço" religioso. Agrradeço à Elena Calvo-Gonzalez por ter apontado esta questão. 0 assunto surgiu entre nós ao levarmos vários amigos estrangeiros e de classe média para consultas e realização de ebós, quando percebemos o constrangimento de alguns deles ao saber que teriam que se "expor" de tal maneira. 
Desse modo se, como foi dito acima, saber quem é o dono de uma cabeça possibilita uma forma de autoconhecimento, uma forma de interpretação de si mesmo, é preciso agora considerar o fato de que, no candomblé, essa interpretação se dá numa operação muito mais complexa, que deve levar em conta todo um conjunto de entidades, além da relação com outros dentro e fora do terreiro.

Bastide (2001, p. 189) já havia apontado para as correlações entre divindades e identidade dos adeptos nas religiões afro-brasileiras. Para o autor o que se passava no transe era uma metamorfose da personalidade cotidiana do fiel na do deus, o que possibilitaria uma compensação, pela inversão, das condições de vida desfavoráveis e da posição social desvalorizada dos adeptos do candomblé. ${ }^{85} \mathrm{Na}$ interpretação de Prandi (1991, p. 176-182) trata-se de uma "multiplicação dos 'eus"” disponíveis aos inciados, na forma de papéis ritualmente exercidos que possibilita tal compensação. Como argumentou Goldman (1985) tais interpretações mantêm não questionada uma certa noção de personalidade como uma entidade realmente existente, completa e fechada em si mesma que pode ser substituída por outras ou desdobrada e Bastide terminaria por recorrer ao conceito de "inconsciente" da psicanálise ocidental para explicar essa substituição. Desse ponto de vista, a incorporação aparece como algo "estranho" que requer uma explicação exterior a ela mesma nas frustrações causadas pelas condições de vida. Goldman sustentou que é a própria noção de pessoa peculiar ao candomblé que está em jogo no fenômeno da possessão. Diferentemente da concepção individualista que foi delineada acima, a pessoa no candomblé não é compreendida como uma unidade fechada em si mesma, "acabada"

85 Apesar da crítica de Goldman (1985, p. 29) quanto à interpretação do transe através de algo que lhe é exterior, pelo fato de Bastide não levar às últimas consequências a noção de pessoa particular do candomblé, é importante mencionar que o segundo já apresentava em suas análises grande sensibilidade a aspectos como a interação entre diversas pessoas incorporadas o que levou o autor a sugerir que a possessão não era um fenômeno individual isolado, mas sim "intermental", cujos estímulos decorriam de um "outro mundo" (BASTIDE, 2001, p. 190) e que a dança, os gestos, as expressões eram toda uma "linguagem" (BASTIDE, 2001, p. 209) capaz de exprimir a experiência mística dos "negros do candomblé". 
e dotada de autonomia. A pessoa tem que ser "feita", ou nas palavras do autor, construída ritualmente. Como já foi argumentado aqui, este processo constrói simultaneamente as divindades individualizadas - que tem nome específico e morada no ibá - e as pessoas singularizadas numa série de relações particulares com as entidades. No caso do "eu" que se desdobra na multiplicidade de papéis, cabe questionar se todo o sentido da experiência da divindade seria de fato dado nessa referência que lhe é exterior.

Desse modo, tornar-se uma pessoa não significa alcançar a maturidade para tomar decisões e executá-las de maneira autônoma, mas se submeter a ritos que visam fixar as relações com as divindades que compõem a pessoa de modo a buscar um equilíbrio do próprio ser. Em outros termos, as ligações pessoais com as entidades não têm como resultado classificar pessoas tanto quanto produzi-las. (GOLDMAN, 1985, p. 36) Tal como Bastide (2001, p. 226-230) já havia afirmado, está em jogo a ontologia do ser humano: para o candomblé pode-se ser menos ou mais, o que coloca em cheque a dualidade radical entre ser e nada. Retomando a ideia apresentada na seção anterior da identidade pessoal como um projeto reflexivamente orientado - e que pode incluir os conhecimentos religiosos - a consequência da proposição de que a religião constrói ritualmente a pessoa é que não se trata apenas de uma interpretação de si mesmo, mas de um fazer-se no contexto religioso, atuando com outros, com suas regras, concepções e limites rituais. Entretanto, é possível, mais uma vez, criticar a ênfase excessiva na relação reflexiva do sujeito consigo mesmo e, como já foi enfatizado, este "fazer" da pessoa no candomblé é público.

Para Augras (1983, p. 60-61) é preciso olhar diretamente a experiência vivida dos membros para se compreender as consequências dessas relações entre seres humanos e divinos. Estas relações, no presente caso, comportam uma dualidade: as pessoas não são deuses - alteridade - , mas compartilham de sua natureza - identidade. É importante notar que para a autora a dualidade entre mesmo 
e outro é fundamental a todas as religiões, mas cada uma apresenta uma solução específica. A questão central aqui é a da relação do ser humano com a finitude, ou seja, a morte, a alteridade radical e inaceitável que afirma sua realidade diante da vida. (AUGRAS, 1983, p. 15) No caso do candomblé esta alteridade é construída numa série de divindades que encarnam as potências: os orixás, que são forças da natureza e da cultura. Sendo potências eles são compreendidos como forças exteriores, com vontade e conhecimento próprio, capazes de se impor aos seres humanos. Entretanto, a relação não é de alteridade exclusiva, pois os elementos fundamentais que compõem sua "cabeça” são os mesmo do orixá que é seu dono (AUGRAS,1983, p. 93) Assim, o orixá não representa apenas o outro, mas também um duplo. O indivíduo não se confunde com o orixá, não se torna o próprio, mas compartilhando de sua essência, também não é estranho a ele. Para Augras, o orixá é a "verdadeira natureza” da pessoa. Como duplos, os deuses são, ao mesmo tempo forças exteriores aos homens e modelos para estes, que são apreendidos através dos mitos que contam suas histórias, façanhas, aspectos, virtudes e defeitos. No processo iniciático a preparação da cabeça para receber o orixá traz a possibilidade de uma identificação com ele - embora por vezes ocorra a negação dessa identidade, principalmente no caso dos "deuses implacáveis" da morte, da guerra e do mato, como Obaluaiê, Ogum e Ossaim, cuja vontade é sentida como soberana, violenta e alheia (AUGRAS, 1983, p. 223) - que envolve tanto um nível consciente, quanto o nível das tensões internas vividas pela pessoa e a metamorfose que tem lugar no transe. ${ }^{86}$

Entretanto, é necessário notar que as divindades não necessariamente apontam para algo "interior" ao sujeito que emerge no transe. Elas contam pelo que são, pelo poder que têm de agir sobre as pessoas:

${ }^{86}$ Apesar de ultrapassar algumas dicotomias e apontar que alteridade e identidade constituem uma dualidade complementar (e não uma oposição), é possível perceber na análise de Augras a permanência de um certo essencialismo na ideia de que, no transe, o indivíduo expressa sua "verdadeira natureza". 
É um renascimento total. Coisas que, como eu disse antes, eu jamais teria paciência pra lidar com as pessoas, eu nunca fui uma pessoa muito paciente no sentido de ouvir, de escutar, de dar atenção a outras pessoas como seres humanos, isso eu não me envergonho de dizer que eu era muito egoísta, eu vivia pra mim e acabou. [...] Não há dúvida de que é influência do orixá. Não há dúvida. Tem horas que $o$ antigo Dary quer tomar a frente e a gente sente o freio, entendeu? Sente aquele banho de água fria assim, que the acalma e transforma na outra pessoa. (Pai Dary)

Ser é um processo construído na estabilização dos vínculos com o orixá de cabeça, o juntó, o exu, o restante do enredo, o erê e o caboclo nas casas que o cultuam, como é o caso do Torrundê. O terreiro a que Irene pertence não cultua os caboclos, mas mesmo assim há toda uma série de divindades cujas energias a compõem. Nicolau-Parés (1997) denominou esta série específica de relações de identidade espiritual, enfatizando a importância das diferentes tradições de cada casa na articulação de tais identidades. Dessa maneira, é possível pensar num continuum que teria num extremo a articulação representada pela Casa das Minas - em São Luís do Maranhão, onde a pesquisa desse autor foi realizada - que se manifesta na incorporação de apenas um vodun por cada iniciada. No polo oposto poderiam ser colocadas outras casas, onde uma mesma iniciada incorpora uma longa lista de entidades a cada enquadramento diverso do ritual, chegando a dez ou quinze diferentes encantados numa mesma cerimônia. (NICOLAU-PARÉS, 1997, p. 171-172) Vários terreiros ocupariam posições intermediárias, regulamentando à sua maneira as relações entre as entidades e seus filhos. Segundo Nicolau-Parés, uma nova identidade pessoal é articulada pela associação simbólica e ritual com um número discreto de entidades espirituais: "O senso de self do médium é aberto e dinâmico". O processo de nomeação de cada uma das entidades ganha relevância por ser um instrumento articulador através do qual as entidades podem ser associadas a certos comportamentos. Aos poucos o médium vai arti- 
culando uma identidade que envolve uma noção de pessoa múltipla diversamente estabelecida por cada ortodoxia. (NICOLAU-PARÉS, 1997, p. 149-150)

No Torrundê, são assentados o dono da cabeça, o exú, o caboclo e juntó na iniciação, mas este último não recebe um assentamento completo até a obrigação de cinco anos que lhe é dedicada e na qual poderá vir dançar. Como é usual nos terreiros, todo filho de santo deverá ser apresentado ao público incorporado por seu orixá de cabeça, quando da feitura e, cinco anos depois, apresentar-se com seu juntó. Seu erê sempre se apresentará quando o orixá partir. Poderá ainda receber seu caboclo nas sessões quinzenais. É preciso, então, focalizar os modos como se dá a articulação entre uma noção de pessoa individualizada e uma outra, múltipla.

Acima, os orixás foram interpretados como um conjunto de "conhecimentos" que vai sendo apropriado no processo de identificação com candomblé, passando a fazer parte da revisão crônica acerca de si mesmo, da retomada reflexiva acerca da identidade pessoal. No entanto, as análises que acentuam a construção dessa identidade no âmbito ritual (GOLDMAN, 1985; NICOLAU-PARÉS, 1997) baseiam-se no fato de que estas identidades são atuadas em contextos religiosos que possibilitam e exigem o engajamento sensorial dos sujeitos. Dessa maneira, ganha importância o fato de que os orixás, caboclos e erês não constituem apenas formas de interpretar o mundo, mas são dotados de vontade própria que podem impor aos humanos, como já foi reiterado e que apresentam um certo estilo, próprio do grupo religioso. A negociação da identidade, dos papéis que se pode assumir, dos degraus de status que se terá que ocupar se dá tanto na interação com outros humanos quanto na relação com outros sagrados. Para os participantes do mundo do candomblé são as divindades que escolhem $^{87}$ quem será ogã, equede, filho de santo, pai ou mãe de santo

87 Evidentemente surgem conflitos frequentes e há sempre a possibilidade de suspeita de que alguém foi favorecido pelo babalorixá ou pela ialorixá em tal procedimento. Nos casos de sucessão nos terreiros, há sempre aqueles descontentes com o eleito pelas divindades e ques- 
e todos os demais cargos que podem ser distribuídos. São elas que determinam a posição que se ocupará no interior do grupo de culto e a negociação com elas se processa através do engajamento corporal nos rituais do terreiro. O que quero dizer é que embora as divindades apresentem uma faceta cognitiva, por assim dizer - que permitiria a identificação através de atributos pessoais, características físicas e comportamentais' - não é este aspecto que tem maior força no processo de identificação e sim sua relação com os adeptos, o que elas podem fazer e isto se dá no âmbito da experiência, muitas vezes imediata, da ação dos orixás. No contexto ritual esta experiência é consolidada segundo proposições específicas aos terreiros que orientam o próprio modo de atentar para o que se vive durante os ritos e o cotidiano. Este ponto será retomado na próxima sessão. Antes, porém há mais uma questão a ser levantada, pois as trajetórias de identificação se dão com um grupo religioso e não apenas entre um indivíduo e as entidades sagradas.

As ênfases de Goldman (1985), no caráter ritual dessa construção, e de Nicolau-Parés (1997), na tradição de cada terreiro na articulação da identidade espiritual, apontam para uma dimensão da interação fortemente demarcada no candomblé: quem eu sou é algo público. Isto tem duas consequências extremamente relevantes. Em primeiro lugar, cada etapa iniciática vencida culmina numa festa em que os orixás vêm dançar. Também ogãs e equedes são confirmados na presença de uma audiência. A identidade que se constrói no candomblé não é aquela dos recônditos de uma suposta "vida interior", mas aquela que é atuada e reconhecida pelo grupo - no sentido amplo, pois estas cerimônias importantes sempre contam com visitantes ilustres de outros terreiros. Não se faz candomblé sozinho em casa, como quem faz uma oração, segue um caminho de meditação ou lê um livro de autoajuda. O candomblé não é uma religião que se

tionamentos podem surgir. No entanto, os descontentes costumam se retirar do grupo ou agir de maneira velada reforçando a ideia de que as divindades encontram-se por trás das escolhas. 
volte, em primeira instância, para a construção de uma interioridade, mas sim para a articulação da pessoa numa série de relações - de parentesco espiritual e com as divindades - que a vincula à história do terreiro e a exibe ao público através de certo estilo de uso do corpo. Exibe-se a performance da dança, exibe-se a boa organização e andamento da cerimônia a cargo dos ogãs e equedes, exibe-se, sobretudo, a manifestação dos orixás.

Em segundo lugar, trata-se de um processo contínuo. Há uma trajetória de identificação que pode ser chamada de inicial, que se desenrola nos momentos de aproximação ao grupo religioso, na passagem da condição de "cliente" - ou apenas "curioso" no presente caso - à de "fiel” (MARIZ; MACHADO, 1998), mas este movimento não se encerra, mesmo com a iniciação. A partir dela é que se abre todo um percurso explícito nos estágios de senioridade (FRIGERIO, 2002) e na relação com um número cada vez maior de entidades. (GOLDMAN, 1985; SEGATO, 1995) Neste ponto as trajetórias daqueles que se confirmam como ogãs e equedes divergem amplamente daqueles que se iniciam como filhos, pois os primeiros adquirem status de maioridade espiritual desde que confirmados, embora também devam reforçar seus vínculos religiosos nas obrigações e não experimentam as diferentes formas de "chegada" das entidades em seus corpos que acompanham esse percurso. Já os segundos mudam de posição hierárquica paulatinamente, nos anos de suas obrigações e, simultaneamente, podem passar por diferentes modos de sentir a aproximação das divindades, tais como o "passar mal" do não iniciado e a chegada rápida nos iaôs recém iniciados. Entretanto, a distinção bem demarcada no âmbito ritual não elimina a importância da convivência, das interações no terreiro para os processos de identificação. Ser de candomblé significa acreditar nos orixás e tomar parte nos rituais e isto só é possível para a presença encarnada do sujeito no terreiro.

Isto não significa que o candomblé não tenha consequências psicológicas importantes, mas antes que ele torna evidente o que religiões marcadamente "subjetivas" podem dissimular: que o su- 
jeito, mesmo o sujeito das crenças íntimas, é constituído na relação com seu mundo. Não cabe colocar as questões do que significa ser de candomblé exclusivamente num nível subjetivo da pessoa. ${ }^{88}$ Cabe perguntar, no entanto, se há sentido em separar tais consequências "subjetivas” da presença "objetiva” no terreiro.

Irene - Porque pra mim era, bobagem, era, subcultura, era... havia uma intencionalidade, qualquer coisa que negasse pra mim tava bom, né? Qualquer coisa que negasse o candomblé como alguma coisa, como uma experiência real. E... mas eu fui ficando lá dentro e eu acho que eu fui, eu fui... modificando, é, o meu comportamento, né? Eu fui assimilando que uma [...] sem essa, é, uma coisa sem, sem aquilo, "vai sê agora".

Luciana - Certo. Sem ter um, uma ideia de que você tava $[\ldots]$.

Irene - Exato. Pra mim, eu estava ali incólume.

Luciana - Conhecendo?

Irene - Conhecendo, vivendo, estudando, lendo, acho que a minha mãe costuma dizer que orixá não chega pelo intelecto, mas eu acho que... é, concordo com ela, né? Em tese, mas eu acho que pra mim foi acontecendo também na medida em que eu fui, vendo, comparando, estudando, percebendo o grupo, né? Percebendo o grupo. Percebendo o que é 'ser', de candomblé, o que é participar do candomblé. O que é pertencer ao grupo, né? Então, é uma coisa que pra mim ainda está acontecendo. (ênfase na entonação)

Mais uma vez Irene disse algo bastante elucidativo: ao lado do aspecto reflexivo de seu contato com o candomblé, ela enfatizou a convivência com o terreiro. Com este breve trecho ela ilustrou a necessidade, que venho reiterando, de se considerar os processos de identificação na religião em vários níveis de análise, pois todos apon-

88 As análises que tratam os orixás como tipos de personalidade e os processos de autoidentificação com referência à assimilação desses tipos, acabam por permanecer neste nível e não aprofundam as consequências do pressuposto de que os deuses têm agência própria, mesmo quando afirmam que este é o ponto de vista dos "nativos". (PRANDI, 1991; SEGATO, 1995) 
tam para questões relevantes. 1) Há o conhecimento estereotipado que permite categorização e um certo nível de autoidentificação, mas não dá conta de como o processo se desenrola; 2) Devemos então pensar que esta construção da identidade espiritual se dá através dos rituais, o que tem duas consequências importantes: a) não apresenta uma noção única e bem delimitada de pessoa múltipla, como mostra Nicolau-Parés (1997) ressaltando a importância das várias tradições de cada casa e assim, como argumentou Segato (1995), a noção de individualidade se combina, e não opõe, à de multiplicidade relacional; tal como a análise de Augras (1983) também demonstra que se trata de uma lógica do "e”, não do “ou”; b) os rituais não estabelecem as relações identitárias de uma vez por todas, o que torna mais evidente o fato de que se trata de um processo aberto e contínuo e já aponta para o engajamento sensorial dos sujeitos; 3) Já que os processos de autoidentificação se desenrolam nas interações, é preciso considerar quem são os outros envolvidos: pessoas e divindades; 4) Se a operação envolve tanto identidade como alteridade, é preciso perguntar o que significa a identidade (compartilhar energias) e a alteridade (os orixás podem fazer muito mais do que pessoas, têm a capacidade de atravessar os mundos e os corpos). Por isso é preciso atentar para os contextos dessas relações e como elas são compreendidas pelos que as vivenciam.

\section{"EU SOU FILHO DO ORIXÁ": PROCESSOS DE AUTOIDENTIFICAÇÃO}

Irene disse que ela "não tem espada”, que quem "tem espada é Oxum". Mais adiante ela esclareceu que é preciso desenvolver uma "leitura" correta das energias que são os orixás:

[... pra eu não cair na asneira de querer ser mais orixá do que o orixá. E aí eu sair quebrando mundo, né? Ou consertando mundo, ou devastando com o mundo, devastando com o mundo, né? Então, a questão, nesse, nesse momento, né? A questão do iniciado é fazer a leitura correta das energias. Ai você tem que aprender fazer isso todos os dias, todas as horas. E ainda faz errado. 
Nestes últimos cinco anos, ouvi inúmeras vezes afirmações desse tipo, de que uma pessoa é filha do orixá e não o orixá, tanto nas entrevistas como em conversas informais, tanto de pessoas do Torrundê como de outros terreiros. A princípio minha interpretação era bastante rasteira. Eu acreditava que meus interlocutores tentavam me mostrar o óbvio: que humanos e divindades são seres de naturezas diferentes e que os primeiros não se tornam os segundos por compartilhar de algo em comum. Pedro, por exemplo, tentou me explicar esta relação comparando-a com a herança genética familiar: "Você tem genes do seu tio, porque ele é irmão do seu pai, isso não quer dizer que vocês todos são iguais”.

A reiterada ênfase em explicações desse tipo só começou a despertar minha atenção devido a um aprofundamento teórico que trouxe novas questões. Nas entrevistas, ao pedir que as pessoas me apontassem as maneiras como se identificavam com seus orixás - já que quase todas respondiam afirmativamente - eu esperava ouvir uma série de atributos que correspondessem a uns e outros. Algumas vezes tais atributos foram de fato mencionados, como no caso de equede Hortência que se considera uma pessoa sisuda e acredita compartilhar esta característica com Obaluaiê, seu orixá de frente. Contudo, esta parecia não ser a questão central e, em geral, as respostas prosseguiam indicando uma série de feitos dos orixás ou maneiras como as pessoas sentiam sua presença.

Francisco dá um bom exemplo. Provavelmente por ser um rapaz bonito, de jeito ágil e rápido, as pessoas de candomblé que conheceu costumavam lhe atribuir Oxóssi como orixá de cabeça, como já foi visto acima. Quando foi jogar, porém, Oxum se revelou como sua mãe e Oxóssi como seu juntó. Ele próprio acredita apresentar características mais marcantes do seu segundo orixá, como a agilidade e a rapidez de raciocínio, mas pensa que orixá "é muito mais do que isso". Ao tentar me explicar, além da recorrente afirmação dos orixás como energias, Francisco afirmou que sente a presença deles, dessas energias, assim como sente Oxum com ele quando está numa situa- 
ção difícil, prestes a explodir e a reagir violentamente e "ela vem e acalma, coloca seu jeito diplomático". Da mesma forma, diz ele que quando se atribui um orixá a alguém - fora do jogo de búzios, numa tentativa de acerto - é porque se percebe a energia daquele orixá naquela pessoa. É importante lembrar que ele é um ogã e, portanto, esse sentir a energia, não tem relação direta com ser tomado pelo orixá.

Fábio, que é filho de santo, me explicou de forma um tanto semelhante como se dá a identificação de um filho com seu orixá:

Se você perguntar: 'você tem características dele' [orixá]? Algumas [pessoas] tem, mas não é cem por cento. Quando o orixá atua muito na sua vida, mistura muito a energia dele com a sua, na minha opinião, não tô falando por todo o mundo, ele tá doando uma parte da energia dele, você vai absorver essa energia, vai absorver as características dele também. É por isso que tem gente de Iemanjá que é assim, tem gente de Oxalá que é assado, tem gente de Oxóssi que é diferente. Cê tá entendendo? Na minha origem o elemento é esse [ferro, Ogum]. Ai você vai me perguntar, 'ah, mas ele já era assim antes de ele frequentar a religião'. Só que o orixá é atuante na sua vida mesmo antes de frequentar a religião, só que você ainda não despertou pra isso.

Minha incompreensão era decorrente do fato de que eu não percebia as divindades como forças atuantes na vida das pessoas e, assim, esperava que elas me apresentassem algumas "listas de correspondências" com seus "tipos psicológicos". Eu tentava fornecer exemplos, desenvolver mais o assunto e não chegava a interpretações satisfatórias. Simplesmente porque a interpretação não deixava espaço para o que as pessoas tentavam explicar. Era a negação da agência dos orixás o que impedia a compreensão e não uma inadequação das respostas. Uma limitação um tanto semelhante parece ser o teor da observação de Rita Laura Segato:

Por tratar o tema desta maneira, concentrando-me na relação racional de significante e significado que vincula cada orixá a um determinado tipo de personalidade, consegui francamente passar por cima do fato de que a atribuição de 
um orixá a uma pessoa se faz por meio do método de adivinhação ('o jogo de búzios'). Para dar um exemplo, sendo que meu orixá é Iansã, que, segundo acredito, me descreve com bastante aproximação, não soube que papel dar na redação final da etnografia (Segato, 1984) ao fato de que cada vez que os búzios foram jogados para mim, efetivamente, caíram na posição em que Iansã 'fala'. Para dizer a verdade, teria sido possível discorrer sobre tudo o que me interessava sem necessitar fazer menção desta 'coincidência' apenas uma vez. Contudo me pergunto: o que é prescindível, acessório, aqui? (SEGATO, 1992 apud SILVA, 1998, p. 149, grifo nosso)

Com o passar do tempo, desenvolvi a hipótese de que a identificação com as entidades espirituais não se dá através dos conceitos ${ }^{89}$ que se tem delas, mas através do que é percebido como sua ação. Que fique claro que tal posição não foi tomada em decorrência de uma conversão pessoal à crença nas divindades, mas sim de um esforço teórico que levou à reformulação das questões. Outro exemplo ilustra a dissociação entre crença pessoal e interpretação das relações dos entrevistados com os orixás. Até o presente momento pai Dary é obrigado a chamar minha atenção para o fato de que não é a crença de cada um que dá eficácia à ação das divindades. Ainda hoje, minha predisposição me leva a considerar que os ebós devem ser feitos somente para pessoas que creem neles, caso contrário serão ineficazes. Isto é o oposto da noção corrente que afirma a independência da vontade dos deuses. O argumento do babalorixá é que, se minha posição estivesse correta, não seria possível se fazer um trabalho para alguém sem que a pessoa soubesse e, no entanto, muitas vezes são terceiros que solicitam a realização do procedimento sem o conhecimento do beneficiário ou vítima. Este é o caso, por exemplo, de todos os ebós

89 É importante observar que, ao menos em Salvador, o candomblé tem uma presença pública bastante evidente. Assim, há uma ampla difusão de um conhecimento mínimo acerca de alguns orixás, especialmente Oxalá, lemanjá, lansã, Oxum e Ogum. Com isto, muita gente de classe média compartilha de certas concepções, bastante estereotipadas é verdade, sobre fiIhos desses orixás. Isto pode inclusive despertar a curiosidade inicial que move muitas dessas pessoas a um primeiro contato com os terreiros, como ocorreu com alguns dos entrevistados. 
realizados domesticamente para tentar obter o afeto de uma pessoa desejada.

Como já foi discutido na seção anterior, não se trata de desconsiderar completamente a possibilidade de que as divindades sejam tomadas como conhecimentos ou categorizações. Apenas isto parece ser um modo superficial de relação com elas, marcando muito mais os estágios iniciais da identificação com o grupo de culto. A relação entre filhos e orixás se configura nas ações (o que uns e outros podem fazer), muito mais do que no plano da representação de uns e outros. Os orixás atuam na vida de seus filhos, dirigem seus destinos, "orientam e protegem”, como disse pai Dary. O orixá é uma energia da natureza e o dono da cabeça de cada um é uma parcela dessa energia e, assim, a pessoa tem em si uma parcela do orixá. (GOLDMAN, 1985, p. 45) Estas relações são estabilizadas através de rituais (bori, iniciação, confirmação, obrigações) que exigem um engajamento sensorial dos envolvidos. (RABELO, 2008b, p. 104-105) Assim, emerge mais uma possibilidade de análise: ao lado da agência dos deuses, podemos colocar questões sobre como esta ação é sentida e compreendida. Isto aponta para o que acontece à pessoa na experiência da relação com as divindades. Por exemplo, muitas vezes este "contato" se realiza através de sonhos ou outros "sinais" da vontade dos orixás, constituindo momentos propriamente interpretativos da relação. Não somente as pessoas são identificadas recorrendo-se às divindades. Estas últimas também vão sendo identificadas nesta hermenêutica de sua agência. Todos os pontos do argumento que desenvolvi nesta seção apontam para a possibilidade de se colocar questões acerca da identidade pessoal no âmbito da ação.

Acima, procurei destacar algumas características da maneira como os entrevistados se apropriam das proposições religiosas, especialmente sobre a natureza das divindades e sua forma de relação com seus filhos. É preciso levar em conta o fato de que essas interpretações se apoiaram muito fortemente no material das entrevistas gravadas, embora não exclusivamente. Assim, é necessário ponderar, 
mesmo que de forma breve, sobre as relações entre as narrativas de um processo de aproximação ao terreiro e as identidades pessoais..$^{90}$

Do ponto de vista de Lamarque (2004) as origens estruturalistas da crítica literária e da narratologia podem ser responsabilizadas por um excesso de peso atribuído às narrativas na criação da realidade humana.

Isto encorajou certos mitos acerca da narrativa que precisam ser confrontados: por exemplo, que todas as narrativas são au fond ficcionais, que as narrativas criam os objetos ou eventos que descrevem, que o self é uma criação das narrativas, que estas são completas com começos, meios e fins (possuem "fechamento"), que não há estrutura de eventos independente da narrativa e que, mesmo quando estas descrevem uma realidade independente, inevitavelmente, distorcem tal realidade. (LAMARQUE, 2004, p. 393, grifo do autor)

Embora as narrativas ocupem lugar proeminente na prática, não podem ser equacionadas à experiência, no mínimo porque uma narrativa é uma história (i.é. uma ordenação de eventos) que é contada e "não encontrada”. (LAMARQUE, 2004, p. 394) Não há narrativa sem narração. Neste sentido, as entrevistas utilizadas são narrativas propriamente falando. Elas apresentam uma dimensão temporal e várias sequências de fatos são situadas temporalmente umas em relação às outras. Mais ainda, estes são contados como inter-relacionados, formando uma ordenação, mesmo que precária e revista nas várias retomadas, como quando o entrevistado se lembra de um detalhe que havia deixado de lado. Isto já é suficiente para colocar a questão perturbadora: se tenho acesso apenas às narrativas dessas pessoas, como saber que não há - ou qual o grau de - distorção da realidade que elas me apresentam? Se as histórias que me foram contadas criaram os eventos referidos, qual é o sentido disso?

90 Não pretendo aqui elaborar uma discussão a respeito da produção da narrativa etnográfica ou científica, assunto por demais extenso e muito além do escopo deste projeto. (CLIFFORD, 1986; GEERTZ, 1989; SILVA, 1998) Pretendo apenas explicitar algumas questões acerca da relação entre narrativa e experiência. 
Ainda segundo Lamarque (2004) tal tipo de questão se assenta no pressuposto de que a distorção é uma característica exclusiva das narrativas, por serem seletivas e apresentarem um ponto de vista. Para o autor este é, na verdade, um traço presente em toda linguagem. (LAMARQUE, 2004, p. 399) Em toda percepção e experiência, eu acrescentaria, já que mesmo um simples "eu não alcanço aquela prateleira" já traz um ponto de vista implícito, o do sujeito que não tem meios para efetuar a ação. A ideia de que as narrativas criam os eventos por darem-lhes ordenação - não apenas cronológica, mas motivacional e causal - é descartada pelo autor porque não há razão para supor que os acontecimentos - ou experiências - sejam desprovidos de qualquer ordenação previamente à sua descrição narrativa. (LAMARQUE, 2004, p. 400) Em suma, as narrativas são de fato fonte de sentidos e interpretações, mas isto não é o mesmo que dizer que a prática a qual elas se referem - descrevem, retratam ou analisam - seja desprovida de sentido enquanto não for tornada objeto de uma narrativa.

Mattingly (1998) defende um ponto semelhante quanto à questão da estrutura da experiência. De acordo com a autora, a experiência vivida não é um bombardeio pré-linguístico de sensações sem sentido. Tampouco tem seu sentido dado exclusivamente nos modelos (scripts) culturais que delimitam os enquadramentos da experiencia. (MATTINGLY, 1998, p. 44) A própria vida não é experimentada como mera sequência. Quando olhamos para o passado não vemos uma linha contínua se estendendo para trás até onde a memória alcança, mas sim "picos" de intensidades variadas erguidos ao redor de certos eventos mais marcantes. Ao projetar o futuro, tampouco nos vemos num quadro cronológico, mas antecipamos imagens afetivamente carregadas. (MATTINGLY, 1998, p. 45) As pessoas “enredam” (emplot) até mesmo suas ações cotidianas ao tentar compreender o comportamento de outros. Ou seja, elas tentam dirigi-las como episódio de uma história mais ampla na qual é possível entrever os sentidos de uma ação: 
Ser um ator, de fato, significa tentar fazer certas coisas acontecerem; tentar criar certos finais desejáveis, procurar por possibilidades que levem em direções cheias de esperança [...] E às vezes nós somos até capazes de negociar com outros atores de forma que podemos nos mover cooperativamente, cumulativamente nessas direções. A ausência de forma não é tanto uma descrição da estrutura da vida cotidiana quanto um retrato do desespero. (MATTINGLY, 1998, p. 47, tradução nossa)

Se contar uma história ou evento lhe impõe algum sentido isto não significa que a experiência mesma seja caótica e desordenada, mas apenas que ela não é enclausurada no passado. Novas interpretações são possíveis, evidentemente, a partir de diferentes perspectivas. O que elas revelam não é exatamente uma ficção, mas algo de interesse para a pesquisa socioantropológica: o ponto de vista do entrevistado sobre as questões que lhe coloca o pesquisador. Nos termos de Mattingly, elas revelam a "moral da história”, algo mais profundo e importante do que uma mera sequência causal de eventos. As narrativas, então, “acrescentam” sentido às ações não porque este seja ausente na experiência e sim porque as narrativas são retomadas e têm lugar em certos contextos de interação que estabelecem o que está em jogo, qual é o ponto. Nesse sentido, podemos dizer que as histórias que me foram contadas tinham um sentido já dado de antemão para os entrevistados. Isto, porém, não encerrava todas as possibilidades. A incompreensão da relação com os orixás mencionada na seção anterior exemplifica a constante retomada e reinterpretação do que foi dito e registrado.

Argumentos como os de Lamarque (2004) e Mattingly (1998) apontam ainda outra característica comum entre narrativas e vida pessoal: sua abertura. Na maior parte dos casos, narrativas pessoais não chegam a uma conclusão. As direções que podem seguir ficam em aberto, tal como a própria experiência. Assim, o uso de material registrado aqui não se assenta sobre o pressuposto de que as narrativas constituem cópia fiel do que foi vivido por quem as conta, mas 
sim de que apresentam uma das maneiras pelas quais os sujeitos voltam-se para si mesmos e para os eventos vividos, objetos da história.

No entanto, resta ainda o problema da relação dos pontos de vista narrados com as identidades pessoais, objeto de interesse aqui, já que não podemos equacionar a autoidentidade (mesmo as formulações com características de um projeto reflexivo) com a narrativa. Isto seria equivalente a dizer que só há identidade quando há uma história contada. Na maior parte da vida da maioria das pessoas, não é necessária uma narração acerca de si mesmo para que haja um senso de identidade, para que se saiba "quem sou eu":

Entretanto, se a unidade de uma vida depende de alguma forma da unidade de uma narrativa, então a maiorias das vidas irão se revelar sem unidade alguma porque não há tal narrativa. Mas isto é uma reductio porque uma vida é sempre a vida de alguém. [...] Narrativas são histórias que só existem quando são contadas. Sem narração não há narrativa. Contudo, onde não há narrativa parece ilegítimo inferir que não há sujeito do pensamento ou da ação. (LAMARQUE, 2004, p. 404, grifo do autor)

Proposições deste tipo confrontam a posição de Giddens (1991, p. 5) para quem a autoidentidade assumiu, na alta modernidade, as características de um projeto, tornando-se um esforço reflexivamente organizado. De fato, embora especifique que este esforço torna-se uma disposição permanente (que é exigida pela necessidade de "escolher" entre estilos de vida, imposta aos indivíduos pelo contexto), o autor coloca demasiada ênfase na reflexividade dos processos identitários - o próprio self, para ele, consiste em sustentar narrativas biográficas coerentes, que podem, no entanto, ser constantemente revisadas. (GIDDENS, 1991) Segundo Lamarque (2004, p. 405), as maneiras como alguém concebe a si mesmo podem ser narrativamente organizadas, mas estas narrativas não esgotam sua identidade. Extrapolando o argumento de Mattingly - que não investiga diretamente questões de identificação, mas toca constantemente no ponto ao tratar das limitações de pacientes de reabilitação - é pre- 
ciso atentar para como os sujeitos se engajam naquilo que podem ou não fazer. De pontos de vista distintos, Mattingly e Lamarque apontam para a necessidade de se ir além das narrativas em investigações acerca da identidade pessoal.

Assim, os relatos são considerados como tematizações que recortam e qualificam certos eventos, destacando-os do conjunto de experiências de uma vida, a partir da perspectiva pessoal assumida no contexto de uma entrevista sobre si mesmo. É possível, ainda, questionar se a ênfase na agência individual não seria fruto da retomada reflexiva da própria história, no esforço de oferecer um relato minimamente coerente. Há a possibilidade de que a tematização narrativa reforce o aspecto reflexivo do engajamento pessoal se, como sugeri, esta pode fazer emergir novos sentidos a depender do contexto. Entretanto, mesmo que o acento individualista diga muito mais respeito à história contada do que à vivida, não há porque considerá-lo "falso", mas apenas como participante da disposição permanente à retomada reflexiva de si mesmo como centro ativo de uma biografia. É possível tomá-lo como o ponto de vista do sujeito sobre sua história e é importante considerar também este aspecto na análise. Além disso, os mesmos relatos dão espaço para a emergência de influências "externas" e de resultados inesperados, o que me levou a reiterar a necessidade de um tratamento mais nuançado das concepções expressadas.

Tal como no processo de construir objetos de pensamento a partir das percepções, as narrativas objetificam e qualificam os eventos sobre o horizonte compartilhado da interação e de toda a vida que suporta tais objetificações. Ao delimitar e predicar certos fatos como relevantes, segundo o que se espera no contexto, todos os demais "recuam", mas permanecem como pano de fundo. Este horizonte, porém, não é composto por experiências e percepções caóticas e desordenadas, mas sim pelos sentidos e direções visados no tempo presente das ações (MATTINGLY, 1998; JENKINS, 2002) que não se cristaliza, tampouco se perde de todo com a passagem do tempo. Com 
isto quero dizer que os relatos disponíveis sustentam-se sobre um horizonte de sentidos já vividos, que são retomados no ato de contar. Aqueles, emergentes no presente, referem-se a estes já imersos no horizonte e são eles que se procura retratar ao se tentar "dar uma ideia" do que foram os contatos iniciais e o aprendizado no terreiro.

Além disso, as análises aqui apresentadas não se baseiam apenas em relatos, mas também em observações das interações desenvolvidas no terreiro, isto é, no presente das interações. Mais uma vez, já se imiscui a necessidade de se levar em conta a presença encarnada dos sujeitos nos contextos em que suas ações se desenrolam. Isto, porém, nos leva de volta aos processos identitários, que serão retomados a seguir considerando-se mais um nível de análise. Desde o início deste capítulo vem sendo reiterado que identidades pessoais são processos relacionais, que se desenrolam nas interações. Ao desenvolver este ponto Jenkins (2000, p. 10-11) enfatiza que é preciso levar em conta que as interações (e, portanto, as identidades que se formam a partir delas) se dão entre sujeitos encarnados. O próprio senso de self - e mesmo o mundo social - estão assentados nessa característica básica. Mais ainda, o autor argumenta que uma certa unidade da vida pessoal existe - e coexiste com o constante fluxo, com a mudança - sustentada pelo próprio entorno incorporado em construções, monumentos, lugares e na própria existência corporal dos sujeitos. ${ }^{91}$ Evidentemente a estabilidade encarnada no mundo físico e no corpo individual não evita as transformações, mas constitui sua própria base. Da mesma maneira, se enfatizo que os processos de autoidentificação com o candomblé se dão em interações com outros, é como sujeitos encarnados que os indivíduos comparecem em tais relações.

Não há qualquer problema na afirmação de que todo ser humano tem um suporte físico, corporal e que este é envolvido nas relações sociais, carregado de valorações. Também não é problemático admitir que tais avaliações socialmente posicionadas influenciam sobremaneira a identidade pessoal:

91 Ver Jenkins (2012, p. 272 e 275). 
Ernesto - Porque eu tinha sempre uma preocupação com essa minha identificação que é fora de mim inclusive, não sô só eu que me reconheço como um cara negro, né? Nos ambientes todos que eu andei, sempre me identificavam com a etnia negra. Então sempre tive isso na cabeça.

Luciana - Teve, assim, constrangimentos?

Ernesto - Passei por milhares de constrangimentos.

Luciana - Por ser negro?

Ernesto - Claro.

No entanto, considerar apenas este lado da questão é o mesmo que considerar a pessoa como mero suporte de inscrições culturais. Análises que se mantêm apenas neste nível supõem uma série de dicotomias do tipo mente/corpo, representação/materialidade. Terminam por tratar o sujeito ora como objeto passivo das representações, ora como sujeito desencarnado, mas capaz de refletir sobre as próprias inscrições. Embora processos reflexivos tenham importância na análise de processos de autoidentificação - como já foi discutido no início do capítulo - é preciso cuidado para não enfatizá-los demasiadamente. Como argumentou Budgeon (2003) análises como as de Giddens tendem a sobrevalorizar a dimensão representacional dos processos identitários e, mantendo as dicotomias mencionadas, fazem emergir sujeitos que, embora dotados de agência, são "desencarnados”. Por exemplo, o sujeito que no texto de Giddens (1991, p. 218) toma seu próprio corpo como “objeto" passível de manipulação através de intervenções cosméticas e médicas, desenvolve uma relação instrumental com ele. Quem é dotado de agência, na verdade, é a consciência desencarnada, um puro "sujeito pensante". (BUDGEON, 2003, p. 36-37)

De acordo com McNay (1999, p. 97), acentuar unilateralmente a dimensão das inscrições culturais sobre os corpos envolve o risco de se cair numa sobredeterminação do sujeito, em análises que, paradoxalmente, mantêm um pano de fundo voluntarista. O corpo que é somente objeto da cultura é então apropriado reflexivamente e 
alterado num projeto individual, tal como em Giddens. A proposta, então, é ultrapassar a cisão entre ação e encarnação (embodiment), entre suporte físico e representação, pois:

Como ponto de coincidência entre o físico, o simbólico e o sociológico, o corpo é uma fronteira dinâmica, mutável. O corpo é o umbral através do qual a experiência do mundo vivida pelo sujeito é incorporada e compreendida e, como tal, não é puro objeto nem puro sujeito. Não totalmente objeto já que é o lugar de engajamento no mundo. Tampouco é totalmente sujeito já que há sempre um resíduo material que resiste à incorporação no esquema simbólico dominante. (MCNAY, 1999, p. 98)

Segundo Budgeon (2003, p. 42-47), identidades não se dão apenas no plano representacional (o que impede a consideração dos sujeitos como agentes na construção dos significados atribuídos a suas identidades encarnadas), mas principalmente no engajamento corporal no mundo. Dessa forma, uma análise que leve em conta a corporeidade dos sujeitos não deve se perguntar pelos "significados dos corpos". Deve se perguntar "o que os corpos fazem". Por extensão, não se deve perguntar apenas pelo que os orixás significam, mas também pelo que eles fazem, o que, em certo sentido, os torna equivalentes aos seus filhos humanos: são agentes num mundo em eterna construção.

Evidentemente, o que os orixás podem fazer é uma questão de interpretação. É preciso que eles estejam no horizonte de possibilidades das pessoas. É preciso ter alguma relação com o candomblé para que se possa compreender certos eventos como "obra" dos orixás ou caboclos. No entanto, em certo sentido, todo conhecimento é uma questão de interpretação, já que se dá sobre um horizonte de possibilidades culturalmente dadas de compreensão. Mais uma vez, esta interpretação não é um processo puramente mental que se dá para um indivíduo pensante isolado, uma pura consciência destacada do mundo. Mesmo que os orixás sejam tomados como forma de conhecimento, trata-se de um conhecimento construído de forma compartilhada. No 
caso de Salvador, muitas vezes, compartilhado até mesmo por quem nunca foi a um terreiro. O que quero destacar é que os orixás não são considerados como "signos" que apontam para correspondências com alguma realidade para além deles. Eles fazem parte da realidade em que os que creem vivem - e os que não creem também, segundo os argumentos dos membros do candomblé. Não há qualquer novidade em considerar que o que as divindades podem fazer está dado num horizonte compartilhado que é culturalmente construído. Também o que as pessoas podem fazer tem os seus limites estabelecidos neste horizonte cultural, mas então, é preciso olhar para o mundo em que vivem esses sujeitos para se compreender como se conformam suas identidades pessoais.

Se conhecer o mundo e o outro envolve tanto representações quanto interações entre sujeitos encarnados, esta relação apresenta aspectos reflexivos e também pré-reflexivos. As pessoas acompanhadas nesta pesquisa, no entanto, não chegaram aos terreiros como tábulas rasas, aptas a serem "moldadas" de acordo com novas concepções. Carregavam consigo, em suas identidades, em suas formas de relação com o mundo, uma série de posturas, avaliações e percepções já incorporadas, embora sempre abertas à retomada. Trouxeram consigo seus habitus marcados por sua experiência anterior. Como argumentou Csordas:

O self não é substância nem entidade, mas uma capacidade indeterminada para o engajamento e a orientação no mundo, caracterizado por esforço e reflexividade. Neste sentido o self ocorre como uma conjunção de experiências corporais pré-reflexivas, entorno ou mundo culturalmente constituído e especificidade situacional ou habitus. Processos do self são processos orientadores nos quais aspectos do mundo são tematizados, com o resultado de que o self é objetivado, normalmente, como uma "pessoa" com uma identidade cultural ou um conjunto de identidades. (CSORDAS, 1994, p. 5, grifo do autor, tradução nossa) 
Assim, é preciso procurar construir uma abordagem que busque integrar os diferentes níveis até aqui mencionados, que procure manter uma visão interacional, levando em conta os aspectos reflexivos do processo identitário, a construção sociocultural das posições e valores e a existência fundamentalmente encarnada dos sujeitos no mundo. Trata-se de uma tentativa de situar os sujeitos socialmente, mantê-los como agentes e não ignorar o caráter fluido e aberto das autoidentidades. Ao mesmo tempo, é preciso manter as dimensões socialmente compartilhadas dos limites do mundo existencial dos sujeitos. É necessário considerar as disposições que carregam incorporadas e como estas se relacionam com aquelas exigidas no contexto específico da religião. É claro que não é possível tratar de tais disposições como se configurassem dois grupos bem delimitados que fossem colocados em contato com a entrada no terreiro. Estas são relações em aberto, que ganham diferentes tons em diferentes momentos e contextos. Contudo, é possível estabelecer algumas correlações mais estáveis entre aquilo que foi delimitado como propriedade desta classe (um habitus escolar) e certas práticas que eram desconhecidas dos participantes antes do ingresso no grupo de culto. Também é possível contar com seus comentários acerca de seus percursos de familiarização com as exigências e expectativas do terreiro. 


\section{No terreiro: processos encarnados de autoidentificação}

[A iniciação] muda a maneira que a gente vê as coisas, até a sessão de caboclo que a gente praticamente nem vê mais.

Foi como Marta respondeu à minha mensagem, em março de 2003, perguntando como ela estava após a saída da reclusão. Marta havia passado quatro anos como abiã no Ilê Axé Torrundê Ajagun e foi iniciada em dezembro de 2002, aos 47 anos de idade. Sua resposta parece simples, mas o que exatamente quer dizer uma mudança no modo de "ver as coisas", especialmente quando inclui a possibilidade de não ver? Durante os capítulos precedentes, algumas questões foram propositadamente deixadas de lado. Agora, porém é preciso retornar a elas. Argumentei que os processos de autoidentificação com o candomblé envolvem tanto uma relação da pessoa consigo mesma, quanto com o grupo de culto e com as divindades e que a análise deve levar em conta os aspectos reflexivos e pré-reflexivos envolvidos nas interações concretas, sobre os quais emerge toda reflexão. Este capítulo procura explorar exatamente como o não refletido pode ser 
envolvido numa análise do processo de tornar-se um membro de um terreiro de candomblé.

Várias vezes destaquei que a abertura inerente à autoidentificação com a religião não se cristaliza completamente num dado momento, sendo um processo contínuo. Certos eventos ou características - pessoais, do grupo religioso, da experiência escolar ou profissional - são tematizados num dado momento, operando como espécies de núcleos ao redor dos quais as narrativas são construídas. Contudo, estas não podem ser assimiladas à identidade pessoal, ao senso que a pessoa tem de si mesma, o qual sempre vai muito além das narrativas que produz. O processo em seu desenrolar não perde sua flexibilidade e mesmo o passado pessoal pode ser ressignificado de formas um pouco diferentes, com tons diversos, quando é chamado a fazer sentido, isto é, retomado a partir do presente e é, assim, envolvido no projeto de futuro, seja a tarefa imediata a que o sujeito se lança, seja um futuro somente imaginado. (JENKINS, 2002; LAMARQUE, 2004, p. 405)

Esta flexibilidade da prática humana, porém, não é desprovida de toda estruturação, pois esta é regida por esquemas encarnados (embodied) de avaliação e percepção que estão assentados sobre a constituição fundamentalmente sociocultural do mundo da vida. (CSORDAS, 2002) A cristalização das avaliações e percepções em esquemas corporais nos fala de como o corpo do sujeito (ou do agente social) é irremediavelmente construído por e construtor de distinções culturais, frisando, assim, a impossibilidade de objetos puramente naturais na experiência. Acima e abaixo, por exemplo, não são apenas posições no espaço objetivo - mensurável, abstrato e empiricamente dado - mas antes, são simultaneamente posições relativas ao meu corpo que se move, que alcança ou não um dado lugar e carregadas de valores. Olhar alguém de cima para baixo é uma forma de expressão corporal cujo sentido é bem conhecido em nossa sociedade. 
No primeiro capítulo foi discutida a importância da educação e da escolarização na formação de tais esquemas para profissionais de classe média e como elas constituem um eixo de corte entre "nós" e "outros". Agora a questão é tratar de como a convivência no candomblé aparece para esse habitus escolar, já que ele parece permanecer como a base incorporada que condiciona a aproximação com a própria religião.

\section{HABITUS E EMBODIMENT}

Segundo Csordas (1994, p. 8), Merleau-Ponty buscou tratar dos processos encarnados (embodied) de percepção nos quais a experiência de estar no mundo tem seus "inícios", ao invés de se limitar aos objetos da cultura já constituídos, onde a percepção "termina”. Para tal propôs o conceito de pré-reflexivo ou pré-objetivo. Conceitos, ideias e representações são objetos culturais e não a base da experiência vivida. São resultados da tematização desta experiência, de sua retomada num esforço reflexivo, são formas de objetivação. Embora os objetos da reflexão constituam parcela importante da vida pessoal, é preciso considerar também a maneira como os sujeitos estão imersos junto com outros em um mundo dado, seus modos de engajamento prático neste mundo que, na maior parte das vezes, não exige o recurso à reflexividade, à tematização produtora de objetos. É importante ter em mente que o conceito de pré-objetivo em nenhum momento afasta a ação humana de sua fundamentação cultural. Apenas aponta para modos de envolvimento no mundo e com os outros que antecedem à reflexão e a partir dos quais esta emerge. Estamos imersos num mundo que, sendo humano, é desde sempre carregado de sentidos.

Ainda segundo Csordas (1994), a tematização isolada não dá conta da emergência dos objetos culturais e nem do outro para mim. É preciso refinar a análise com uma teoria sobre a prática, na qual estes dois pontos sejam mantidos como complementares: 
Acabamos de ver que o objetivo de Merleau-Ponty é transpor o estudo da percepção de seus objetos para os processos de objetivação. Paralelamente, o alvo de Bourdieu para uma teoria da prática é mover-se para além da análise dos fatos sociais como opus operatum para uma análise do modus operandi da vida social. Ele encontra este modus operandi no conceito de habitus, definido como um sistema de disposições duráveis. Este sistema constitui o princípio inconsciente, coletivamente inculcado para a geração e a estruturação tanto de práticas quanto de representações. (CSORDAS, 1994, p. 9, grifo nosso, tradução nossa)

Apesar das aproximações há diferenças importantes entre os dois autores. Se Merleau-Ponty acaba por dar mais margem à fluidez, à indeterminação na relação do sujeito com o objeto, Bourdieu (2003) ${ }^{92}$ termina por acentuar a determinação do próprio sujeito. É muito mais fácil ver a face estruturada do habitus operando nas práticas dos agentes, ou sua face estruturante como reprodutora, do que sua qualidade generativa. Embora o autor admita a modificação do habitus ao longo da vida e a aquisição de novos elementos, é muito mais claro como os princípios de estruturação são capazes de posicionar qualquer objeto - ou agente, ou grupo desses - por sua capacidade de aplicação aos campos mais diversos da vida social, do que como são constituídos na e pela prática. E toda possível mudança deve ser reportada a uma alteração no estado das relações de força num campo dado - que tornam habitus consolidados inadequados - ou à trajetória de um indivíduo por posições distintas em tais campos, por exemplo, a idade que transforma um "adulto maduro" em "velho", situando-o de maneira diferente nas relações de produção econômica. É exatamente este movimento que McNay (1999, p. 110-113) faz ao utilizar o conceito de habitus em seu potencial transformador. Como o habitus só se realiza em um campo da prática e cada um destes segue uma lógica relativamente autônoma (exacerbada nas condições contemporâneas), surgem inadequações entre habitus e relações

92 Ver, por exemplo, Bourdieu (2003, p. 101; 1999b). 
estruturais do campo quando consideramos que os agentes não vivem confinados a apenas um deles em sua vida cotidiana. Assim, é o próprio conflito entre as diferentes disposições exigidas às mulheres na vida doméstica, no mercado de trabalho e na intimidade, por exemplo, o que traz um potencial libertador à identidade feminina e não um suposto incremento da reflexividade dos sujeitos na contemporaneidade.

Este tipo de formulação exige um grande cuidado para que o sentido das práticas humanas não seja procurado além delas, já que podem aparecer apenas como encarnações de uma lógica que seria a verdadeira chave para a compreensão dos sentidos que os sujeitos empíricos acreditam existir em suas ações. Mesmo as mudanças nos possíveis sentidos da prática poderiam ser reportadas ao conflito entre lógicas distintas. Deste ponto de vista, o problema é semelhante ao da significação na experiência - isto é, de onde provém o sentido da ação humana. No entanto, para Bourdieu, a prática não tem lugar num mundo caótico, organizado desde fora. Ela mesma é organizadora deste mundo, expressando princípios que se encontram inscritos em lugares e corpos. Dessa forma, toda ação tem sempre sentido, inclusive mais do que os indivíduos podem se dar conta na reflexão. (CSORDAS, 1994, p. 12)

A crítica que Budgeon (2003) dirigiu à Giddens pode ser, então, confrontada à posição de Bourdieu. Como já vimos, para a autora, a ênfase de Giddens na inscrição da cultura sobre os corpos - isto é, como eles podem ser tomados como objeto da prática reflexiva - acaba por apresentar sujeitos desencarnados, embora mantenha sua agência. É importante comparar esta crítica com as proposições de Bourdieu porque ao se acentuar demais a organização social das práticas e valores - sua hierarquia inscrita nos corpos e espaços - e tentar manter uma concepção de agência corre-se o risco do ressurgimento de uma dicotomia. De um lado haveria sujeitos encarnados empíricos, situados, posicionados socialmente. De outro lado, classes de agentes, também socialmente situados. Sobre os primeiros re- 
cairia toda a inscrição que os situa até mesmo naquilo que parece ser o mais biológico (seus gostos, gestos, movimentos) e aos segundos estaria reservada a agência obedecendo a uma lógica própria, interna ao par inclusão/exclusão referente a um campo, a uma dada situação de forças entre diferentes classes de agentes que competem para acumular o capital específico àquela esfera. ${ }^{93}$

Para Csordas, a questão recai no estatuto atribuído por cada um dos autores à indeterminação. Em Merleau-Ponty é a própria percepção que nunca esgota o objeto - mantendo sempre a possibilidade de outros pontos de vista -, enquanto que em Bourdieu (1994, p. 11) trata-se de uma indeterminação lógica, exatamente a que permite a aplicação dos mesmos esquemas de avaliação e percepção aos campos mais diversos e dá conta da variação na vida cotidiana. Portanto, diferentemente da crítica normalmente feita a Bourdieu, o problema de suas proposições não estaria na sobredeterminação econômica do sujeito, mas numa certa autonomização da lógica estrutural: são as diferentes lógicas dos distintos campos, que exigem disposições diversas e, entrando em conflito, oferecem uma certa indeterminação à prática. É preciso cuidado com esta ênfase, pois chega-se perigosamente perto de um sujeito desencarnado e é preciso ater-se ao aspecto produtivo do habitus incorporado para evitar este risco.

Já em Merleau-Ponty a plasticidade é inerente à condição encarnada dos sujeitos, pois a percepção mesma não nos dá objetos

93 É possível questionar ainda a redução de toda lógica de qualquer campo à acumulação de seu capital específico e à operações binárias. No caso do campo religioso pode-se argumentar que há lógicas distintas operando a depender do eixo de corte do campo, por exemplo, todas as instituições religiosas do campo soteropolitano estariam em disputa pelo mesmo capital simbólico. Na esfera do candomblé propriamente dito, os terreiros estariam operando na lógica da acumulação e monopólio do capital religioso, mas dentro de um mesmo terreiro não é frutífero distinguir estritamente entre "produtores" e "consumidores", ou "dominantes" e "dominados". A lógica da dádiva, da acumulação para distribuição, proposta por Mauss (2003b), Caillé (1998) e Bourdieu (1996) parece mais adequada para as análises no interior do grupo. Pode-se contestar que num grupo empírico encontram-se indivíduos com posições diversas em distintos campos (religioso, produção econômica, relações de gênero etc.) e que isto faz com a lógica da acumulação não seja evidente, mas não seria, então, justamente o caso de se pensar numa lógica mais inclusiva, acumulação mais redistribuição, por exemplo? 
- que são produtos secundários do pensamento -, mas facetas, perfis, conclamando a atividade da consciência à “completá-los”, retirá - los da indeterminação. Contudo, pelo próprio fato de ser uma consciência encarnada, situada no mundo com outros - e não uma razão universal, uma faculdade humana, ou qualquer operação de reflexão desencarnada - sua tarefa tem lugar num mundo intersubjetivo e, necessariamente a partir de um ponto de vista nele situado. ${ }^{94}$ Isto quer dizer que esta atividade se dá sempre num horizonte de sentidos culturalmente constituídos. O sujeito encarnado tem os limites de sua percepção e atividade reflexiva no seu entorno já constituído por e com outros, em suma, num mundo intersubjetivo e é a ele que se deve reportar a inteligibilidade das ações. Com isto também se coloca a questão da ininteligibilidade: maiores são as dificuldades quanto mais distantes forem os horizontes culturais da experiência. Por outro lado, da mesma maneira que nenhuma percepção esgota o objeto - ou seja, a transparência nunca é total - tampouco há uma impossibilidade radical de compreensão - e a opacidade nunca é completa. Isto pressuporia um objeto em si acabado ao qual a cognição se lançaria.

Embora os conceitos propostos por Merleau-Ponty enfatizem a natureza cultural do mundo humano, sua formulação pode parecer universalista por demais. Este é o teor da crítica que Weiss (1999) dirigiu ao filósofo, sem discordar do alcance de suas análises. Para acentuar a especificidade de ser um sujeito encarnado no feminino numa dada sociedade (norte-americana contemporânea) a autora propôs um desenvolvimento pormenorizado da noção de imagem corporal, já presente nas discussões do primeiro. Segundo Weiss, a imagem corporal fornece um senso de unidade ao sujeito - que tem e é um

94 Percebe-se aqui uma diferença crucial entre Merleau-Ponty (1962) e Bourdieu (2001). Enquanto que para o segundo é a homologia estrutural entre campos de prática que permite a "leitura" pré-reflexiva de quem é o outro, em Merleau-Ponty é o compartilhamento de sentidos num horizonte de indeterminação que atinge vários níveis, desde o orgânico - no qual o outro tem um corpo como eu - até os objetos culturais propriamente ditos - um certo tom de voz "significa" raiva, por exemplo. 
corpo dotado de uma certa integridade esquemática. Esta se desenvolve a partir dos investimentos afetivos diferenciados em partes ou capacidades do corpo. Assim, diferentes cores de pele recebem investimentos diversos, culturalmente determinados. Da mesma maneira, os sexos. Também os membros, órgãos e funções não são igualmente investidos, por exemplo, a cabeça e as nádegas, ou a fala e a excreção têm pesos diferenciados. Os valores da sociedade não são apostos aos corpos, como avaliações exteriores, mas participam do próprio senso de unidade corporal que sustenta os limites do sujeito. Não se trata apenas de uma exploração das maneiras como culturas são inscritas nos corpos, mas de formas de estar no mundo. A imagem corporal é muito menos uma imagem de si do que uma sistematização das relações intersubjetivamente constituídas com corpos e seus "atributos". Ela esquematiza modos de se voltar para o mundo, para si próprio e para o outro. Sendo indeterminada, isto é, um processo contínuo que não se fecha totalmente ao redor de um atributo ${ }^{95}$ ou conjunto deles, a imagem corporal pode vir a abarcar novos gestos, novos valores, novas potencialidades e incapacidades. Dessa maneira, é uma verdadeira identidade corporal. Como sustentou Jenkins (2002) a existência encarnada fornece um senso de continuidade ao sujeito e ao mundo e, simultaneamente, a base sobre a qual são vividas as transformações.

A noção proposta por Weiss (1999) para caracterizar o senso de integridade subjacente à corporalidade é extremamente próxima a de arco intencional, utilizada por Merleau-Ponty para expressar a unidade nunca dada de antemão do sujeito da percepção:

Protanto, deixem-nos dizer, emprestando um termo de outros trabalhos, que a vida da consciência - vida cognitiva, vida do desejo ou vida perceptiva - é antes subtendida por um 'arco intencional' que projeta em torno de nós nosso passado, nosso futuro, nosso ambiente humano, nossa situação física, ideológica e moral, ou ainda, que resulta do fato de estarmos

95 A rigidificação da imagem corporal em torno de um atributo - por exemplo, a massa corporal - ou um momento da vida, pode mesmo trazer transtornos que se manifestam no que foi chamado de psicopatologias, segundo Weiss (1999). 
situados a todos esses respeitos. É este arco intencional que coloca a unidade dos sentidos, da inteligência, da sensibilidade e da motilidade. (MERLEAU-PONTY, 1962, p. 136)

Esta noção de arco intencional apresenta também o caráter unificador e situado do habitus. Ela também diz respeito à integração de valorações - investimentos afetivos - e práticas distintas num senso de unidade que é o ponto de vista do sujeito encarnado. Mais ainda, diz respeito à capacidade de executar gestos sem que seja necessária uma reflexão acerca das partes do corpo envolvidas, sem correr o risco de sugerir uma "figura mental" de si mesmo, o que ocorre com a noção de imagem corporal. A única vantagem apresentada por esta última é a clareza de exposição quando é necessário enfatizar a incorporação de possibilidades culturais. Assim, toda vez que o termo for utilizado na análise a seguir deverá ser compreendido como uma referência ao arco intencional tal como proposto por Merleau-Ponty (1962).

Se a própria noção de embodiment expressa tanto indeterminação quanto integração e situação, qual seria, então, a necessidade de manter na análise o conceito de habitus se ele realmente ameaça introduzir um mal entendido? Como argumentou Csordas (1994), o conceito permite explorar a especificidade cultural que se encontra pressuposta nas análises de Merleau-Ponty, ou melhor, implicada na noção de intersubjetividade ${ }^{96}$ e manter seu embasamento encarnado, isto é, sem remeter a compreensão e o sentido para uma suposta "camada" reflexiva dos sujeitos, responsável pela significação a posteriori de suas experiências. O habitus possibilita explorar as especificidades de esquemas corporais sem recorrer à noção de "imagem”, criticada acima. Mais ainda, com sua referência necessária ao campo, o habitus permite uma aproximação à especificidade no interior de um mesmo grupo, permite que se considere que há sempre alguma

96 É preciso atentar para o fato de que este conceito não significa a interpenetração de subjetividades isoladas, mas sim uma espécie de tecido de padrões de comportamento que têm lugar no que é chamado de mundo objetivo e vida subjetiva num único e mesmo movimento que, ademais, nunca estanca. (CSORDAS, 1994, p. 12-13) 
compreensão da prática alheia sem que isto implique num suposto compartilhar de representações. O que veremos a seguir é exatamente isto: não é por pertencer a um mesmo terreiro que as pessoas passam a compartilhar, automaticamente, valores, julgamentos ou apreciações. Em outros termos, podemos dizer que o candomblé oferece elementos para distintos estilos de vida, mas não que fornece um único estilo de vida a seus membros.

Evidentemente, nem todos os conflitos e inadequações que emergem nas interações no terreiro podem ser referidos à uma posição específica da classe, escolhida como objeto desta análise. Alguns deles dizem respeito muito mais ao gênero e à idade:

Quem é nova e tem tudo duro que ache que pode mostrar seus peitos a todo o mundo, eu que sou velha é que não vou ficar mostrando tudo por aí.

Estes foram aproximadamente os termos nos quais uma iaô de cerca de 50 anos se queixou do fato de ter que trocar de roupa no mesmo quarto em que os homens o faziam. O fato das filhas de santo mais novas se trocarem sem incômodo num ambiente misto aparecia-lhe claramente como uma impropriedade, algo que "não cai bem" e que ela "não podia fazer". Em duas ocasiões que presenciei no Torrundê, as mulheres mais velhas tentaram tomar posse de um quarto com banheiro só para elas. Na primeira, a tentativa foi frustrada pelas condições físicas em que se encontrava o local: a fiação elétrica não estava boa e as lâmpadas não acendiam, com isto era impossível fechar a porta que, além do mais, estava sem trinco. Na outra, pai Dary havia acabado de construir um novo quarto com banheiro e uma das filhas mais velhas conseguiu o privilégio das chaves. Nas primeiras sessões e festas ela, manteve o controle do acesso ao espaço, admitindo as mais velhas e equedes, é claro, bem como as mais novas e abiãs que eram do seu agrado. No entanto, poucos meses se passaram até que alguns filhos de santo contornassem suas restrições, dando início novamente ao desconforto das mulheres de mais idade. 
No terreiro são frequentes as queixas de abiãs, e mesmo de alguns iaôs, que se julgam vítimas da jocosidade de outros por não saberem dançar bonito, tomar a bênção direito e outros gestos que passam a funcionar como demarcadores entre os "realmente de dentro" e os novatos. Evidentemente nem só os filhos da classe média são vítimas de tais comentários, mas o são preferencialmente, já que não foram - à exceção de Paulo - familiarizados com o candomblé desde a infância e os períodos iniciais na roça envolvem todo um aprendizado gestual para eles. No entanto, embora os adeptos não considerados diretamente neste estudo não constituam um grupo homogêneo e harmonioso (muito ao contrário, como mostram as queixas e brigas frequentes), parecem também ter alguma percepção da distinção que os separa dos primeiros. Um exemplo pode ser visto na diferenciação entre os que ingressam no candomblé por "necessidade" e aqueles que "acham bonito". Frequentemente, pude ouvir entre os filhos de santo de classe popular a censura aos que pensam que a religião é "só para mostrar a saia na roda”, o que pode ser uma alusão direta tanto à qualidade das roupas confeccionas por aqueles com mais recursos financeiros, quanto à ênfase que estes colocam (nos casos aqui estudados) na ideia de que a religião é uma “opção” individual. Eu mesma recebi esta crítica, algumas vezes, por ser uma pessoa que se tornava relativamente próxima sem me tornar, efetivamente, filha de santo.

Em suma, gostaria de sugerir que à flexibilidade inerente às formas de embodiment, o esquematismo corporal do habitus acrescenta uma ênfase em seu caráter integrador. Enquanto que as primeiras nos falam de como corpo e consciência são vividos como uma unidade, tanto no que diz respeito à união inextrincável de ambos na experiência, quanto à solidariedade dos sentidos (MERLEAU-PONTY, 1962, p. 116-120), o segundo expressa uma percepção de conjunto entre elementos tão heterogêneos como vestuário, alimentação, ocupação, tratamento socialmente adequado, posturas valorizadas, entre inúmeros exemplos, formando aquilo a que chamamos estilo de vida. Estes dois conceitos, por manterem a ambiguidade entre determina- 
ção e inovação, nos permitem compreender como o candomblé passa a fazer parte do mundo desses profissionais de classe média, e viceversa, ou como se dá a integração desta religião na vida destas pessoas, sem ignorar os conflitos e as dificuldades que emergem na frequência ao terreiro. Passar a ser de candomblé significa abrir-se para uma série de possibilidades, desde a convivência com pessoas de origem sociocultural muito heterogênea até a incorporação das entidades. Esta abertura só pode ocorrer a partir do enraizamento do sujeito em seu mundo, carregado de clivagens, sobre o qual se estende o arco intencional que sustenta a integração da religião que se escolheu num estilo de vida e num modo de ser. Enquanto as percepções e avaliações que a religião requer não forem incorporadas, muitas situações emergirão como tarefas difíceis ou como conflituosas durante as interações concretas.

\section{INDUMENTÁRIA, CONVIVÊNCIA E HIERARQUIA}

Anteriormente, indiquei que as pessoas acompanhadas nesta pesquisa carregam um habitus escolar - e que sua posição de classe se expressa especialmente numa distinção calcada na "educação" e na "cultura" - que fornece parâmetros para a maneira como elas interagem com outros e os percebem. Suas formas de compreensão da religião e de si mesmos também se apresentam perpassadas por esta matriz, embora em diferentes graus para indivíduos com idades distintas e diversos períodos de engajamento na religião. Assim, para analisar como se dá o processo de identificação com o terreiro de candomblé convém atentar para as inadequações, as dificuldades e impropriedades que surgem nas interações concretas.

A hierarquia religiosa de um terreiro de candomblé se expressa de diversas maneiras práticas. Uma das mais evidentes - quando nos familiarizamos com o código - é o vestuário nas obrigações. Quem 
pode dançar de sapatos, quem pode usar bata ao invés de camisu, ${ }^{97}$ quem pode usar pano da costa, são detalhes que indicam o grau iniciático de cada membro da roça. (BAPTISTA, 2009) Apenas ebomis têm o direito a ostentar tais objetos. Na verdade, há uma série enorme de variações de vestuário que permite inferir a posição de cada um, indo desde estes elementos mais óbvios até o tipo e a espessura do colar de contas que pode ser utilizado. Mais uma vez, há variações entre terreiros de diferentes linhagens, mas algumas regras parecem ser quase um consenso e no Torrundê tive a oportunidade de observar o trabalho dos mais velhos para que os mais novos "permaneçam em seu lugar”. Pai Dary, que é bastante paciente e dado a explicar aos filhos os motivos das exigências, disse uma vez a um grupo de adeptos que, se uma abiã ou uma iaô usarem as roupas dos mais velhos, não serão capazes de sentir a importância da passagem ritual de um status a outro. Seus termos foram mais ou menos os seguintes:

Que importância vai ter pra você quando eu, no meio do barracão, te entregar a bata e disser, 'minha filha, você não usa mais blusa de crioula', se nesses anos todos você já vestiu bata e pano da costa?

Como no Torrundê as obrigações contemplam um, três, cinco e sete anos de iniciação, há distinções de vestuário para cada etapa e recentemente tem havido um esforço mais claro para manter a obediência às regras. Para dirimir dúvidas, o babalorixá havia fixado duas páginas impressas com as normas de conduta e vestimenta, ao lado da porta da cozinha. Nelas podíamos ler que abiãs devem vestir exclusivamente roupas brancas "simples" - isto é, saia sem goma, blusa branca, atacã e ojá simples, para as mulheres e calça de ração com blusa branca para os homens - com apenas o fio de contas de seu orixá, quando já lavado. Iaôs mulheres devem vestir saia com anágua,

97 Um tipo de blusa longa e reta, com decote arredondado e mangas curtas, de algodão, mas que pode ter uma série de enfeites, como bordados, bicos e rendas. Deve ter "fralda", isto é, deve chegar até a altura dos joelhos, com aberturas laterais abaixo dos quadris que facilitam os movimentos. 
atacã, camisu, pano da costa acima da cintura e ojá - que podem ser bordados e enfeitados. Os homens usam uma espécie de bata masculina amarrada sobre um ombro que vai até a altura das coxas e calças parecidas com as dos abiãs, porém de melhor qualidade e mais enfeitadas. Além disso, devem portar os colares referentes à iniciação, os diloguns (longos e grossos, compostos por 16 fios de contas unidos por uma espécie de conta maior, as firmas, a intervalos regulares), além dos contra-eguns e mocãs, feitos de palha da costa trançada. Devem dançar descalços ${ }^{98}$ e não podem usar batas rendadas. Já os homens ebomis podem usar chinelos, um tipo de bata com mangas e um tipo de barrete do mesmo tecido da roupa. As ebomis devem se vestir com a indumentária completa que inclui algumas anáguas, bata rendada e o pano da costa na cintura, além das sandálias e chinelos de salto (evidentemente, a preferência é por modelos fáceis de descalçar, o que terá que ser feito caso o orixá desça). Outro elemento já mencionado são os colares diferenciados que podem ser utilizados e, em geral, já não são feitos de miçangas, mas de contas de cerâmica em formatos, tamanhos e cores variados, ou mesmo de outros materiais como chifre de bois e búfalos. Desse ponto de vista, podemos dizer que a hierarquia encontra-se inscrita no vestuário e sobreposta aos corpos dos iniciados.

Isto diz respeito aos momentos de execução pública dos rituais. Já aí há a questão de se executar todos os movimentos sob tantas camadas de tecido. ${ }^{99}$ Durante todo o tempo que se está presente no terreiro, preparando as cerimônias ou arrumando tudo depois, não se usa roupas “civis” (exceto durantes os trabalhos de reforma, cons-

98 Após o bori, os abiãs devem usar também um fio simples branco de Oxalá. Na obrigaçãa de cinco anos os iaôs ganham o direito de usar chinelos, mas totalmente sem salto, o que é prerrogativa das ebomis. Estas duas distinções não estão impressas, mas são efetivas, servindo de diferenciação interna a cada grupo de membros do terreiro ou causando confusão quando são desconsideradas.

99 Apenas como curiosidade: no primeiro semestre de 2003, em Cleveland, Ohio, EUA, conheci uma Iyanifá (sacerdotisa de Ifá) iniciada em Oyó, Nigéria, que já havia estado em Salvador. Ela comentou comigo, em tom recriminatório, que não sabia como os orixás daqui podiam dançar "amarrados" em tantos panos. 
trução ou escultura, quando todos os envolvidos usam trajes confortáveis e que serão praticamente destruídos pelo contato com materiais como cimento, cal, tintas etc.). Mencionei acima as regras de conduta também afixadas junto à cozinha. Nelas constava que qualquer membro do terreiro deve, logo ao chegar, tomar um banho, vestir-se adequadamente e ir tomar a bênção aos mais velhos. Isto significa vestir as "roupas de ração", blusas ou camisetas, em geral brancas com calças largas ou saias simples de algodão resistente, branco ou estampado. As saias de ração não são diferentes daquelas menos elaboradas, usadas nas sessões de caboclo, ou pelas abiãs o tempo todo. ${ }^{100}$ Com esta vestimenta serão realizadas todas as tarefas. Talvez para os homens isso não represente muita diferença do modo cotidiano de se vestir, já que suas roupas são leves e eles usam calças, mas para as mulheres, significa ter que varrer, lavar panelas imensas, fazer comida, tratar a carne de animais, sentar, agachar, levantar, usando saias amplas que muitas vezes entram no caminho. Pode ser esta a razão do hábito de se amarrá-las acima do busto ou sobre um dos ombros, prendendo a cintura com um ojá, da maneira como os caboclos fazem quando tomam os corpos de suas filhas nas sessões. Dessa forma as saias ficam pela altura dos joelhos, não chegando aos tornozelos, mas mesmo assim, ainda comportam uma boa quantidade de tecido que, muitas vezes, é segurada no meio das pernas de modo a não atrapalhar. É claro que isto só é possível quando a atividade exige mais movimentos das mãos e braços. As mulheres mais velhas não costumam vestir suas saias dessa maneira e sim normalmente, na cintura. Prendem, então, algumas partes da barra no cós, diminuindo a movimentação do tecido.

De toda forma, temos aqui uma situação na qual o vestuário dos rituais públicos evidencia a inscrição da hierarquia sobre os corpos dos membros do terreiro, ao passo que as vestimentas de trabalho

\footnotetext{
100 É importante ressaltar que o "simples" no candomblé significa apenas "um pouco menos elaborado", sendo bastante bem cuidado e até mesmo as roupas de ração podem ostentar bordados e outros "enfeites".
} 
evidenciam uma forma de requisitar o corpo, certas exigências de movimentação. Nas roupas das festas podemos ver a demarcação de proximidades e distâncias nos termos hierárquicos da própria religião. Nas roupas de ração uma demarcação de distância com relação às atividades cotidianas. Passar a ser de candomblé significa, entre muitas coisas, mover-se com naturalidade em trajes não costumeiros para a maioria de nós em Salvador. As tarefas executadas também não fazem parte do cotidiano usual de uma grande cidade, mas serão objeto da próxima sessão. Por enquanto é interessante ter em mente que tais indumentárias de trabalho constituem o primeiro conjunto de vestuário que um abiã irá providenciar. Assim, logo no início de sua aproximação com o terreiro ele - sobretudo ela - terá que se vestir de certa maneira e apropriar-se de um modo de se mover e, como argumentou Merleau-Ponty (1962, p. 106):

Nunca movemos nosso corpo objetivo, mas sim nosso corpo fenomênico e não há qualquer mistério nisso, uma vez que nosso corpo, como potencialidade desta ou daquela parte do mundo, é o que se levanta em direção aos objetos a serem apanhados e os percebe.

Assim, ao colocar exigências aos modos de movimentação de seus membros, o candomblé está estabelecendo os limites de seu mundo. Ao reivindicar formas de movimentos antes não usuais, podemos dizer que a religião está forçando tais limites para além daqueles já incorporados em seu habitus. Em resumo, isto é o que será apresentado durante todo este capítulo, porém, sob vários aspectos. Por ora, retornemos às interações no terreiro, pois é através delas que podemos observar tais exigências.

A hierarquia do terreiro, no entanto, não se limita à expressão nos suportes materiais de roupas, cadeiras e posições - posição física - no barracão. Ela é também praticada em uma série de gestos, como tomar a bênção e ocupar o lugar certo na roda. Os mais novos devem, idealmente, descalçar-se e deitar aos pés da pessoa a quem pedem bênção. Há ainda uma diferenciação a depender do sexo do orixá de 
cabeça: os que têm orixás masculinos deitam-se de frente, com o corpo reto; os que têm orixás femininos deitam-se apoiando primeiro um lado do corpo, deitando-se completamente depois e girando os quadris de um lado para o outro. Ao se tornar ebomi a pessoa não precisará mais se deitar. Apenas se curvará um pouco, estendendo as mãos na direção daquele que dará a bênção. ${ }^{101}$ Os mais novos devem sempre tomar a iniciativa do pedido, mesmo quando o status de ambos é igual, cabendo ao mais velho abençoar primeiro para só depois devolver a solicitação. Isto tudo compõe um quadro ideal. Na prática, na correria da cerimônia pública iminente, os próprios mais velhos impedem que abiãs e iaôs deitem-se no chão, bastando a menção de fazê-lo para que sejam abençoados. O gesto, mesmo interrompido em seu início, não perde seu valor e é reconhecido como uma adequação da atitude da pessoa às exigências da hierarquia religiosa. Muitas vezes, porém, as pessoas pedem a benção àquelas com quem têm mais afinidade e não a todos os seus mais velhos, abrindo mais uma possibilidade de conflito.

Mais uma vez, a situação descrita não diz respeito exclusivamente aos profissionais de classe média e sim a qualquer pessoa que não tenha crescido no ambiente do candomblé. Entretanto é especialmente apta a entrar em choque com sua posição socioeconômica. A maioria das pessoas que entrevistei expressou uma valoração positiva da obediência a tais normas, mesmo que esta tenha vindo com o tempo. É o caso de pai Robson, para quem o candomblé foi "um exercício de humildade". Sua família, porém não compartilhava dessa opinião:

Chegou ao ponto do meu pai nunca ter ido no candomblé me ver, porque não admitia. Ele dizia, 'eu te criei, eu te eduquei, você nunca... você quando quer dar a benção você dá e quando não, você passa por mim é 'bom dia'. Pra te ver deitar nos pés de um homem pra que ele te abençoe'?!

${ }^{101}$ No Torrundê o gesto de beijar a mão do outro e deixar a sua ser beijada depois não é habitual, embora eu tenha observado esta forma de troca de bênçãos em muitos outros terreiros de Salvador. 
A emergência de conflitos em torno dessa questão depende muito de idiossincrasias, pois alguns mais velhos não se importam tanto enquanto que para outros é uma ofensa grave que os mais novos não lhes demonstrem esse sinal de respeito. Da mesma forma, alguns dos mais novos se esforçam para não cometer a gafe, ao passo que outros são mais relaxados. Nem por isso a expressão do respeito pela hierarquia através dessa atitude perde a importância para os membros do terreiro. Já ouvi algumas vezes a menção a Fábio como um filho de santo exemplar e em uma delas (na sua obrigação de sete anos) seu comportamento para com os mais velhos e os orixás foi referido como modelo a ser seguido.

No extremo oposto, mais uma vez, o caso de Rosana é interessante. Já mencionei que um de seus maiores problemas de adaptação ao terreiro foi com relação a tomar a bênção. Ela se recusava terminantemente a fazê-lo para qualquer outra pessoa que não fosse pai Dary. Não achava adequado ter que se "deitar" para outras pessoas. No terreiro em que ela havia iniciado um tratamento espiritual, antes de conhecer o Torrundê, houve também o mesmo conflito:

Aí, depois ela [a mãe de santo] disse que ia fazer um negócio de noite e que eu tinha que dar a bênção. E me ensinou que eu tinha que dar a bênção, como é o nome? Que eu tinha que beijar os pés. Ai eu disse, ai foi que pegou o negócio. [risos] Eu saí, não voltei mais.

Já foi dito que Rosana considerava pai Dary "uma pessoa como nós” e tinha confiança nele. Talvez por isso não se importasse em lhe tomar a bênção. As tensões em torno da hierarquia foram, anteriormente, analisadas em relação à sua fundamentação e às expectativas de legitimidade por parte dos adeptos de classe média. Agora, vemos outro aspecto da mesma questão. Isto evidencia que as perspectivas analíticas não esgotam qualquer objeto e que é sempre possível retomá-los e fazer emergir sentidos a depender do ponto de vista. Uma interpretação não elimina as outras, mas procurando agregar formas distintas de abordar um mesmo tema, podemos en- 
contrar maneiras de enunciar vários sentidos que se conjugam na prática. Por ora, o que desejo acentuar é que valor e gesto são inseparáveis.

Nas vezes em que Rosana pediu minha opinião e a aconselhei a cumprir a regra, lhe perguntei o porquê de sua dificuldade. Ela não sabia responder com clareza, dizia que não gostava, que não tinha idade para isso. Era algo que não lhe caía bem. Tomar a bênção é um ato de prostrar-se frente à outra pessoa, descer ao nível de seus pés. Era dessa forma que Rosana compreendia um ato que pode ser sentido de maneira completamente diferente: como um colocar-se sob a proteção de alguém com maior poder espiritual. Na verdade, ela não gostava de executar nenhum gesto que incluísse agachar ou deitar-se. É preciso ponderar também que Rosana já se aproximava dos 50 anos de idade, o que, provavelmente, acrescentava uma dificuldade "orgânica” à execução de tais gestos. Isto, porém, não era apenas "dado", sendo constantemente retomado por ela como justificativa, o que evidencia a profunda imbricação entre o "físico" e o "valorativo". Sua existência corporal como uma mulher de uma certa idade era frequentemente tematizada, colocando uma dificuldade adicional ao seu engajamento nos gestos exigidos. Em seu caso, os esquemas de avaliação já incorporados falaram mais alto do que sua relação ainda inicial com o grupo de culto e geraram uma série de conflitos e antipatias que culminaram com seu afastamento sob a pecha de "maluca". Até comigo ela rompeu relações, passando mais de um mês sem me dirigir a palavra, devido à minha insistência para que ela tentasse se adequar às regras do terreiro, talvez, somada ao fato de minha lenta aproximação com a Iá Morô, uma das pessoas com quem ela entrava em confronto mais direto. O que julgo mais interessante neste caso, contudo, é o modo como Rosana tematizou um gesto valorizado no interior do grupo de culto (deitar-se para tomar a benção) como uma dificuldade praticamente insuperável.

Ao contrário do que me disseram Hortência e Ernesto, o terreiro não vive em tensão como qualquer lugar onde se junte muita gente. 
O terreiro não é um lugar como outro qualquer, suas regras e exigências são específicas e os conflitos que emergem giram em torno delas. Como ele mesmo disse, é difícil aprender o seu lugar, "na frente de quem" não se pode passar. Há muitas outras normas envolvidas nesta questão da hierarquia, por exemplo, quem pode ser chamado pelo nome ou apelido e quem deve ser chamado pelo cargo. Mais do que um conjunto de representações acerca do status de cada um, é preciso aprender a se "situar". O "lugar" que se ocupa requer um modo de se dirigir aos outros. No caso dos profissionais de classe média, esse modo muitas vezes significa uma inversão das posturas do cotidiano, ou mesmo das relações de poder entre pessoas de origem social diferente (SILVA, 1998, p. 86-87), quando é o caso de uma professora universitária, ou um médico se deitar para ser abençoado pela diarista. Em outras situações, trata-se de um conflito entre o que é tido como a maneira adequada de se tratar alguém com quem se tem um vínculo afetivo (saudar alegremente, abraçar e beijar no rosto) e a maneira adequada de se tratar alguém no candomblé, que exige o cumprimento de certas normas quanto ao corpo (tomar banho e vestir-se com as roupas de ração) e quanto aos gestos (colocar-se abaixo da outra pessoa, deitando-se ou curvando-se, e pedir-lhe a bênção).

Este, porém, é apenas um primeiro ponto de aproximação à questão. A presença no terreiro exige muito mais do que vestir certas roupas e respeitar uma hierarquia.

\section{LIMPAR GALINHAS E OUTROS GESTOS DIFÍCEIS}

No capítulo anterior reiterei que a autoidentificação com o candomblé deve ser pensada com relação às tarefas executadas e às relações com pessoas concretas, e não apenas como um movimento reflexivo do sujeito. Já vimos que a inserção dessas pessoas na comunidade de culto é sobremaneira marcada pela emergência de vários conflitos e especialmente no que diz respeito às atividades de preparação das cerimônias. Este é um âmbito de atividade privilegiado para se pensar a autoidentificação como processo encarnado, pois exige - 
e evidencia - exatamente a presença corporal dos sujeitos na roça. Da parte dos filhos de santo, ogãs e equedes mais disponíveis para as atividades religiosas, o modo de agir dos membros de classe média é muitas vezes classificado como "preguiça" e "privilégios" dados pelo babalorixá. Alguns entrevistados chegam a corroborar esta ideia, como Ana:

Ai tem que lavar o prato, tratar a galinha, nunca tinha pego uma galinha antes de entrar no candomblé. Até hoje, se eu puder, eu fujo. Tanto que eu sou conhecida, eu, Silvia e Rita. Iá briga com a gente, dizendo que nós somos as preguiçosas de lá. Realmente, varrer chão, pra lavar, até minha mãe olhava pra mim e ficava me criticando, 'ah, em Paripe, por que em Paripe você faz? E em sua casa não?’

No entanto, tais posturas não podem ser pensadas como fechadas, inalteráveis e com significado estável (tampouco pode-se pensar que a avaliação por parte dos outros filhos de santo é homogênea, sempre de crítica). Ana prossegue um pouco mais à frente, depois de relatar o choque inicial com a vida no terreiro:

As pessoas criticam, 'ah, filhinha branquinha, filhinha preguiçosa, filhinha isso, a filhinha aquilo', já falaram sim. Mas tinha as irmãs que eram boazinhas, me ajudaram até um pouquinho. [...] Como Regina, ela via o meu desespero porque eu tratava galinha nas pontas dos dedos pra não sujar a mão. Quer dizer, eu acho que foi coisa de chatice mesmo, educação mal dada.

A última parte da fala de Ana aponta para algo de extrema importância aqui. Não apenas como argumentou McNay (1999), que a inadequação do habitus às exigências do campo é a condição de emergência da reflexividade, mas esta pode se voltar para uma valoração negativa da conduta própria e não da alheia, mas este ponto será retomado mais adiante. Por ora quero me ater a um dos elementos de sua formulação: o vocabulário em que as pessoas expressam a inadequação entre disposições e situação concreta é o do desconhe- 
cimento e da limitação das possibilidades de agir. Na fala de Marta, isto é muito mais evidente:

Elas [as ebomis] reclamam que a gente é lerda, mas nunca na vida me ensinaram a tratar galinha.

Foi o que ela comentou comigo ao sermos repreendidas por ainda não termos terminado a finalização da limpeza das aves que seriam cozidas para a festa naquela noite. O problema com as galinhas é interessante porque aponta para muito mais do que um desconhecimento cognitivo, sugerindo que aprender é uma reivindicação de certos gestos e certas sensibilidades. De fato não é qualquer pessoa dos círculos de classe média que pode pegar uma ave recém-sacrificada, ainda quente, "despir" sua pele coberta de penas com as mãos e depois mergulhá-las em suas entranhas para retirar seu interior. É preciso ter um certo jeito de segurar, aplicar uma certa força e em certas direções. Além de tudo, não é qualquer pessoa que pode manipular as vísceras dos animais oferecidos, pois certas partes (coração e "miúdos") contém axé. É preciso saber também quando parar de realizar a tarefa. Talvez o interesse despertado por esta atividade em especial resida em seus aspectos sensoriais. Entrar em contato com sangue, com corpos de animais abatidos é uma das maneiras como o candomblé requer o engajamento de seus membros e que tem grandes probabilidades de entrar em choque com a experiência cotidiana de muitos habitantes das grandes cidades, sejam eles de classe média ou não. No entanto, para estes especialmente, no terreiro, havia um despreparo para tais afazeres, que são atividades manuais desvalorizadas em nossa sociedade. Mesmo uma pessoa que saiba executar todas as tarefas domésticas dificilmente apresentará as disposições necessárias para desempenhar com destreza o que é exigido, devido as suas dimensões: tudo no terreiro é excessivo, as panelas são enormes, os pratos são incontáveis, a comida é preparada em quantidades "industriais". No caso das pessoas de classe média, a socialização distante dos terreiros de candomblé não favorece a incorporação precoce de tais disposições. Entretanto, quanto a isto, é interessante 
ressaltar um contraste surgido nas entrevistas. Enquanto que a questão da "boa educação" apareceu como um forte demarcador de posição social, o aprendizado de tais tarefas não foi desvalorizado como "propriedade" de um grupo de status mais baixo. Isto sugere que tais gestos, quando apropriados pelos indivíduos pesquisados, são tidos como "propriedade" do grupo religioso, não diminuindo necessariamente o status daqueles que os desempenham.

Dessa forma, uma boa parte dos conflitos emergentes nas interações concretas entre membros do terreiro pode ser interpretada não nos termos da "preguiça" de que são acusados - muitas vezes observei iaôs que não eram de classe média "fugindo do pesado", escondidos pelos cantos da roça, fazendo um lanche ou fumando -, mas em termos da inadequação das disposições às exigências das tarefas. Mesmo aquelas mais simples, como varrer, requerem um certo uso do corpo que não estava disponível para pessoas como Ana, que sequer lavava pratos em casa. Evidentemente, por ser mulher tive acesso muito maior aos comentários das mulheres (além da experiência direta) e pude observar seus comportamentos muito mais de perto, pois ficava restrita a sua área de atividade. Tenho apenas os relatos dos homens quanto ao que passaram e algumas observações. De toda maneira, foi possível perceber que para eles as atividades envolvem muito mais diretamente a força física. São eles que auxiliam nas obras do terreiro, carregam sacos de cimento, quebram paredes, como disse Pedro e são encarregados de tratar os animais de maior porte, bodes e cabras, oferecidos aos orixás. Fábio mencionou explicitamente esta experiência ao relatar seus primeiros meses no terreiro. Como já foi dito, ele conheceu a roça em seus primórdios, quando ela tinha poucas construções e ele sequer havia completado 20 anos:

E uma coisa que eu gostei de lá também, foi que tinha muita gente da minha idade. Porque se eu chegasse num lugar que tivesse um bocado de velho, que ficasse sentado, que eu ia pra Paripe eu tava com 17, eu ia fazer o que lá? Então, lá a gente jogava dominó, a gente jogava buraco, a gente carregava pedra nas costas. Os filhinhos de papai da Barra, 
que era como a gente era chamado lá, carregando pedra nas costas. [risos]

As críticas dirigidas aos filhos de santo de classe média nos termos da preguiça e do privilégio têm um pressuposto voluntarista e reducionista ao mesmo tempo. Reducionista porque equaciona classe - no terreiro sentida como algo que se expressa no bairro de residência, no automóvel e no emprego formal - a um comportamento homogêneo: fazer apenas os trabalhos "leves" de decoração ou participar somente quando os rituais já estão preparados. Nesse sentido, ela pode ser considerada como uma categorização dessas pessoas, pelos demais membros com quem interagem (JENKINS, 2000), com a qual nem sempre concordam, tampouco correspondem. Voluntarista porque pressupõe que basta ao indivíduo desejar para que possa desempenhar uma tarefa.

É verdade que as pessoas aqui focalizadas permanecem menos tempo no terreiro, não comparecem às quartas-feiras ${ }^{102}$ - em geral, mas Marta passou seu último ano de abiã indo praticamente toda semana - para ajudar na execução dos ebós e muitas vezes permanecem alheias às atividades de limpeza e preparo da comida, o que dificulta seu aprendizado das tarefas. Contudo, isto não pode ser generalizado e, ao menos os dois primeiros pontos estão diretamente correlacionados ao seu estilo de vida regulado pelo compasso do emprego formal de 40 horas semanais, às vezes mais. Mesmo pai Dary não reside o tempo todo na roça, dividindo seu tempo entre ela e seu apartamento na Cidade Baixa, muito mais próximo aos seus dois locais de trabalho, uma clínica particular e um posto municipal de saúde. O ritmo de atividades do próprio terreiro se encontra marcado pelo ritmo do mercado de trabalho formal. Além disso, esses profissionais de classe média permanecem mais próximos das atividades do terreiro nos primeiros anos logo após a iniciação, o que pode ser generalizado para adeptos de qualquer classe social.

102 Devido à agenda profissional de pai Dary, as quartas-feiras são os dias preferenciais para a realização de consultas e ebós. 
Quando perguntados se havia conflitos de horários entre suas outras atividades - trabalho, lazer, família - e as religiosas, vários deles me contaram (inclusive os de outros terreiros) que já haviam participado mais ativamente, mas que naquele momento, não iam com tanta frequência. ${ }^{103}$

Assim, ao contrário da interpretação "nativa" que acentua a falta de "vontade", as dificuldades na execução do preparo das cerimônias apontam exatamente para o ponto central do processo de autoidentificação com a religião: trata-se de uma apropriação das disposições adequadas. Trata-se de "apanhar" um gesto, voltar-se para ele e realizá-lo sem que seja necessário refletir. Esta apropriação é possível porque a imagem corporal - a integração esquemática de suas possibilidades - não é estável, embora tampouco seja totalmente fluída. As novas possibilidades do corpo podem ser, aos poucos, incorporadas e executadas sem qualquer problematização, como no caso de Fábio, que prosseguiu após rir um pouco, quando eu perguntei se eles "batiam laje":

Batendo laje. Só que era prazeroso pra gente porque a gente saía daquele mundo que a gente vivia. Porque eu, você me perguntou 'qual a classe que você se enquadra?', 'Classe média baixa'. Mas só que essa classe média que eu vivo aqui, é um mundo totalmente diferente de você ir pro subúrbio, entendeu? A gente passa a ter um convívio com pessoas totalmente diferentes. Então a gente era os filhinhos de papai da Barra, carregando pedra nas costas.

É também a situação de Pedro que hoje se encontra à vontade com as atividades na roça:

Eu aprendi com o convívio, logo no começo do candomblé, quando eu realmente fiz o santo, eu aprendi o seguinte: ogã é pau pra toda obra. E isso eu aplico em mim, não em to-

${ }^{103}$ Outro ponto interessante é que o trabalho tem prioridade sobre a presença no terreiro, mas não as atividades familiares. Quando são obrigados a escolher entre essas duas últimas, a roça é preterida em casos considerados excepcionais, como o aniversário de 90 anos da tia-avó de Fábio. Evidentemente, isto gera mais conflitos familiares. 
dos os ogãs lá da roça, nem em outros ogãs de outra roça, mas eu aplico em mim, se precisar tocar eu toco, se precisar cantar eu canto, se precisar cortar eu corto, se precisar vestir o santo, eu 'visto'... Se precisar despachar o santo eu despacho, se precisar pintar eu pinto, se precisar quebrar uma parede eu quebro, se precisar carregar um saco de cimento eu carrego. (ênfase na entonação).

A fala de Pedro evidencia o que várias pessoas chamaram de "o grande aprendizado" que representou seu ingresso no candomblé. Aqui fica claro que esse aprendizado dizia respeito, basicamente, a duas questões: aprender a executar atividades desconhecidas e a conviver com pessoas muito distintas. Em ambos os casos trata-se de muito mais do que uma mudança de representações. É preciso aprender a interagir, a se situar bem diante do outro e dentro das regras do grupo. Isto significa executar e compreender gestos e tons, muito mais do que aprender conteúdos objetivos. Aprender a executar tarefas é aprender uma maneira de mover-se, de dirigir-se para certos objetos - por exemplo, a galinha a ser limpa - sem que os próprios gestos sejam objeto de reflexão, o que dificulta a realização das mesmas, ao mesmo tempo em que expressa a inadequação. Como escreveu Merleau-Ponty (1962, p. 142), “[...] é o corpo que 'apanha' e 'compreende' o movimento" e é a imagem corporal que se alarga, incorporando os "instrumentos" (ou apetrechos) com os quais o corpo aprende a se mover e é sempre como um corpo socialmente situado que este se lança a esse aprendizado. Isto quer dizer que as dificuldades, as recusas, os desgostos (e, sobretudo, o nojo que se sente em certas circunstâncias) dizem algo a respeito da posição de tais sujeitos num espaço constituído por valorações socialmente construídas. (BOURDIEU, 2001a, p. 164)

Pode-se objetar que todas as pessoas acima mencionadas que se saíram bem neste processo de aproximação ao terreiro eram bastante jovens (entre 17 e 20 anos), mas situações semelhantes foram narradas por pessoas que chegaram bem mais velhas ao candomblé, tal como Irene, que se iniciou aos 46 anos. 
Irene - É, na verdade foi, mas ele [seu companheiro] foi iniciado primeiro do que eu. Que ele... ele ficô lá e logo ele foi levantado ogã, foi confirmado e eu fiquei. Primeiro eu era, quando eu cheguei lá, eu fui... eu era 'mulher de ogã', as pessoas me serviam, tudo, né? E depois, nem entendo mesmo como é que foi que eu deixei de ser 'mulher de ogã ' e passei a ser abiã. Quer dizer a ...

Luciana - Aí mudou completamente a posição na hierarquia. Irene - Ai mudou completamente, ao invés de ficar sentada naquele lugar lá, que é destinado pras mulheres dos ogãs, ai eu ficava cá, ah! Junto com Antônia! [também entrevistada] Que Antônia na época também era abiã. Né? Então a gente ficava junto, lavava muito prato. Servia as pessoas na festa, né? Fazia os menores trabalhos que tinha pra fazer, a gente fazia. (ênfase na entonação).

Desse modo, o estilo próprio do candomblé de requisitar o engajamento de seus membros, mesmo fora dos momentos rituais propriamente ditos, possibilita a incorporação de novos gestos, novas posturas ao esquema corporal. A pessoa se torna capaz de fazer coisas que desconhecia, como tocar os atabaques nos variados ritmos das divindades. Esta apropriação - é disso que se trata, de tornar "apropriado" e também "meu próprio" - é sustentada pelo arco intencional. Ela é uma maneira de voltar-se para as tarefas, para os gestos, para os sons, para o mundo. Não se restringe a uma suposta "vida interior" do sujeito, mas dirige-se para "fora", para as ações e os outros. Ou melhor, ela estabelece, num mesmo movimento, os limites das capacidades e do contexto onde elas passam a existir. Elas delimitam a experiência que é simultaneamente de si e do mundo. Assim, passar a ser de candomblé é uma maneira de se situar frente ao mundo e de dirigir-se a ele. Como foi argumentado no capítulo anterior, o modo de se relacionar e interagir no universo social é fundamental para a identidade pessoal. A autoidentificação com o candomblé é um mesmo processo em duas direções simultaneamente (JENKINS, 2002, p. 275): em direção ao sujeito e ao seu mundo. 
Sugeri acima que o candomblé tem um estilo próprio de solicitar o engajamento de seus participantes. Embora as atividades e tarefas mencionadas sejam importantes para a compreensão de como se desenrola o processo de autoidentificação de profissionais de classe média com o terreiro, é preciso considerar, agora, um aspecto de fundamental importância. Trata-se de uma religião e, portanto, é essencial atentar para suas proposições acerca do plano espiritual também do ponto de vista do engajamento corporal dos sujeitos.

\section{INCORPORANDO HABITUS E DIVINDADES}

De acordo com a perspectiva analítica desenvolvida aqui, o candomblé pode ser pensado como construção de possibilidades de exploração do mundo pelo sujeito. Considerar os aspectos pré-reflexivos da ação e o engajamento corporal em atividades com outros, é o mesmo que apresentá-la como uma forma de se dirigir ao mundo, de lançarse em atividades e interações. Alguns pontos específicos ao grupo religioso já foram mencionados com relação à hierarquia, ao vestuário e aos trabalhos de preparação dos rituais. A seguir serão considerados momentos mais "próximos" à incorporação das divindades, isto é, situações que ocorrem em rituais propriamente ditos.

Em geral, as festas do candomblé se iniciam com o xirê, uma espécie de abertura na qual os ogãs tocam os ritmos dos vários orixás e os filhos da casa dançam numa roda. É o momento inicial de saudação às divindades. Mesmo antes que estas desçam nos corpos de seus filhos, esta fase do ritual já apresenta um elemento interessante para consideração: a maneira de dançar que esta religião solicita não é a mais usual em nossa sociedade, ao menos para pessoas de classe média. Os vários ritmos tocados são relacionados a certos passos e estilos de movimento diferenciados, correspondentes a cada orixá. Por exemplo, as danças das iabás das águas, Oxum e Iemanjá, envolvem gestos suaves, um uso dos braços que ocupa mais o espaço ao redor dos quadris, enquanto que a dança de orixás como Ogum e Iansã são pródigas em movimentos mais rápidos e retilíneos, que ocupam mais 
a frente e o alto. (BÁRBARA, 2000, p. 57-58) Começar a aprender tais movimentos é uma tarefa árdua para aqueles que não cresceram no ambiente de um terreiro, sejam eles de classe média ou não. Os que são familiarizados na roça desde a infância apresentam menos dificuldades. É comum ver crianças pequenas imitando a dança na roda, fazendo sua própria dança em locais menos visíveis ou imitando os orixás. Para elas, essa é uma forma de exploração do espaço ao seu redor com a qual contam desde sempre. Para quem vem de outros contextos, no entanto, é necessário aprender a desempenhar os gestos.

Os movimentos de dança no candomblé exigem uma postura dos pés, envolvendo o apoio sobre toda a sola, e não somente sobre as pontas dos mesmos, tal como é indicativo de elegância feminina em nossa sociedade, vide a popularidade dos saltos altos. ${ }^{104} \mathrm{Pude}$ observar que algumas das melhores dançarinas costumam inclusive levantar os dedos enquanto dançam, mantendo-se totalmente sobre as plantas dos pés. Muitas vezes os orixás incorporados também fazem isto. Além disso, há uma variedade de passos calcados em contratempos que seguem os difíceis ritmos dos atabaques e um amplo uso do espaço lateral do corpo. Tal estilo pode não ser problemático para quem cresce sabendo sambar à moda baiana, que consiste numa alternação rápida dos pés à frente e atrás, enquanto que os quadris se movem para os lados, para cima e para baixo, num ritmo contínuo. Para quem cresce num mundo onde os gestos podem ser coordenados de tal maneira, em várias direções ao mesmo tempo, captar os movimentos de dança do candomblé pode ser muito simples. Entretanto, para quem vem de um universo onde o corpo é educado nos ritmos da Educação Física dos colégios, ou das academias de ginástica, dança e esportes é bem mais problemático. Uma boa parte dos movimentos exigidos nestes ambientes mantém o equilíbrio através de uma divi-

${ }^{104}$ É interessante notar a diferença marcante entre as danças das mulheres iaôs e das ebomis no xirê, especialmente quando estas têm mais idade. Enquanto as primeiras parecem esmerar-se em executar os passos de cada ritmo de modo que sejam claramente diferentes entre si, as ebomis parecem exibir um "domínio contido" dos passos que parece tornar todos eles um pouco uniformes e ainda assim preservar alguma diferenciação. 
são do corpo em duas metades laterais, enquanto uma se projeta, a outra sustenta o peso. É usual, por exemplo, que ao projetar o braço direito à frente, a perna esquerda vá para trás. Nas danças do xirê o equilíbrio é mantido de maneira muito mais próxima à da Capoeira ou de artes marciais orientais: jogando-se o peso sobre as plantas dos pés e os joelhos. A ideia parece ser que o equilíbrio é alcançado por uma forma "equânime" de assentar o corpo sobre o chão, isto é, do modo mais bem distribuído possível, sem se basear numa oposição coordenada do lado esquerdo e do direito para que um contrabalance o movimento do outro. Muitos movimentos das danças no candomblé exigem que perna e braço esquerdo, por exemplo, movam-se na mesma direção ao mesmo tempo.

Assim, os primeiros passos de dança no candomblé vêm como um esforço consciente para executar os movimentos adequados. Mesmo para aqueles que já trazem algumas disposições incorporadas que tornam o aprendizado menos problemático, o início do processo ainda pode exigir uma objetificação dos gestos: procura-se atentar para as sequências de movimentos, para uma certa flexão dos joelhos ou braços, para toda a postura e para o ritmo. Algumas pessoas nunca aprenderão a dançar bem, outras, mesmo de classe média e chegando tarde da vida aos terreiros, podem aprender. De toda a forma, o que o processo envolve é a transformação dos gestos de esforço reflexivo em movimento espontâneo, ou seja, trata-se verdadeiramente de uma incorporação dos gestos adequados.

Um movimento é aprendido quando o corpo o compreendeu, isto é, quando o incorporou em seu "mundo", e mover seu próprio corpo é mirar as coisas através dele, é permitir-se responder ao seu chamado, que é dirigido ao corpo independente de qualquer representação. (MERLEAU-PONTY, 1962, p. 139)

Desta maneira, a incorporação de novos gestos é a incorporação de uma nova maneira de voltar-se para o mundo e interagir com os objetos que lá estão. Aprender a dançar é ter incorporado as roupas 
diferentes que se usa e o entorno onde se dá o movimento de tal forma que nenhum de seus elementos precise assomar à consciência. É não sentir mais o equilíbrio do próprio corpo, pois ele já retornou ao horizonte dos gestos possíveis, não precisando mais ser tematizado. Quando consideramos que "se mover" é um modo de estar no mundo, imerso em suas distâncias e lugares, vemos que é uma forma de perceber, de explorar e interagir com o entorno. Este, porém, nunca é um espaço abstrato, mensurável, objetivo - aquele compreendido em metros e coordenadas -, mas sempre um espaço situado em relação ao ponto de vista do sujeito encarnado (MERLEAU-PONTY, 1962, p. 107-108), é um espaço que sustenta suas possibilidades e incapacidades. Além disso, é um espaço compartilhado que carrega valores e afetos intersubjetivamente investidos numa espécie de topografia sociocultural. (BOURDIEU, 2001a) A reiteração da importância de movimentos e gestos se deve à sua adequação para enfatizar que entrar no mundo do candomblé não se limita ao compartilhar de certas ideias e representações, mas também de uma série de disposições incorporadas.

O candomblé coloca ainda uma solicitação mais radical aos corpos de muitos de seus iniciados: eles devem receber seus orixás, erês e caboclos. No capítulo anterior foram destacadas as relações dos filhos com suas entidades pessoais. Dentre estas destaquei a ação dos deuses na vida dos seres humanos como um elemento fundamental à compreensão do mundo religioso e, portanto, no qual têm lugar os processos de autoidentificação. Agora, focalizando especificamente os movimentos pelos quais o candomblé dirige a exploração do entorno por seus participantes, é preciso retomar esta questão. Boa parte dos esforços rituais tem por objetivo regular a incorporação das entidades, que muitas vezes se dá de forma "desordenada", como nos casos em que as pessoas começam a "dar passagem" a caboclos e exus, principalmente, fora do ambiente de um terreiro. Também é comum que frequentadores não iniciados e abiãs "passem mal” durante certas cerimônias, isto é, que sintam a presença do orixá, mas não os 
incorporem completamente. Nestes casos, pode-se sentir taquicardia, tonturas, frio ou calor, ter suores, a visão turva, ou muitas outras sensações de mal-estar. Os entrevistados que admitiram ter passado por um período de manifestação “incompleta”, afirmaram ser muito desagradável permanecer neste estado:

Porque tu sente, tanto assim que, a minha experiência ainda é recente nessa coisa, né? Uma sensação, assim, depois que passa aquele minuto, aquele, não sei quanto tempo, pouco tempo, tu tá transpirando, tu tá... é uma descarga de energia muito grande. (Marta).

Nos terreiros também é possível observar com frequência pessoas passando por tal situação, precisando ser amparadas por alguém ao lado, girando sobre si mesmas ou tentando fugir do barracão. No período em que frequentou o terreiro, Rosana passava com frequência por esta situação, ameaçando perder o equilíbrio e apoiando-se em quem estivesse ao lado, com olhar esgazeado. Segundo ela, a ideia de "sair do ar" era assustadora e, justamente, esse elemento era utilizado por uma das filhas de santo da vizinhança para atormentar Rosana em momentos de descontração, afirmando que ela iria "rodar”, que o santo iria "lhe pegar".

A iniciação "normaliza" a passagem do orixá e um iaô novo tende a receber o dono de sua cabeça em praticamente todos os momentos rituais que favoreçam a decida da divindade, como boris e oferendas feitas no terreiro. Nesta "preparação" uma grande atenção é dirigida ao corpo que é manipulado de diversas formas, numa longa série de rituais que visam estabelecer, ou “equilibrar”, como dizem os membros do Torrundê, a relação com as divindades. (BASTIDE, 1983; RABELO; MOTA; NUNES, 2002; RABELO, 2005) Os cabelos são completamente raspados e pequenas incisões, chamadas curas, são feitas nos braços, nas omoplatas e no alto da cabeça. Substâncias sagradas são preparadas e colocadas sobre estes cortes. As curas devem permitir a comunicação do axé e o contato com os orixás. Ao mesmo tempo são inscrições, no sentido que demarcam o pertencimento da 
pessoa a um grupo. Elas são de fato "sinais”, mas que “abrem” o corpo e não apenas apontam para algo além dele, ou melhor, se as curas "significam" algo é exatamente as possibilidades construídas pela iniciação, pois não se trata apenas de uma inscrição, mas também de abertura e fechamento. Seguindo a proposta de Budegeon (2003), no esforço de ultrapassar a dicotomia entre representação e materialidade, é preciso perguntar-se não somente como a cultura inscreve seus significados nos corpos, mas também o que estes "podem fazer".

Como vimos ao considerar a identidade espiritual, as possibilidades de incorporação das divindades são diferentemente articuladas no interior da tradição de cada terreiro, ou de famílias destes. (NICOLAU-PARÉS, 1997, p. 149-172) Assim, se trata de uma verdadeira construção de possibilidades e de eliminação de outras. Por exemplo, em muitos terreiros, como no Torrundê, há culto aos caboclos, portanto, a incorporação por estes é uma possibilidade encorajada a todos os filhos de santo. Alguns chegam ao terreiro já recebendo seus caboclos em casa ou em outras circunstâncias. Outros são iniciados, seu orixá de cabeça se manifesta, bem como seu erê, mas não seu caboclo. De qualquer forma, o caboclo está sempre presente no horizonte de possibilidades destas pessoas. Ao contrário, a incorporação por Exu não. Em muitas casas o culto a este orixá é feito sem sua presença nos corpos dos filhos. Os membros da roça não devem receber Exu. No entanto, várias pessoas chegam ao Torrundê apresentando esta manifestação. Uma das primeiras providências, nestes casos, é fazer uma limpeza e procurar agradar ao orixá para que pare de tomar o corpo da pessoa. Na verdade, a teoria local afirma que não se trata do orixá Exu propriamente dito, mas que ele pode usar a energia de alguns eguns e misturar-se a ela para poder incorporar. ${ }^{105}$ Embora muitas pessoas tenham boas relações com seus Exus e Pombagiras - que dão conselhos e ajuda -, no terreiro isto não é visto com tranquilidade. Assim, ao lado da proposição de abertura do corpo, o candomblé também opera uma restrição referente à tradição

1050 mesmo tipo de explicação é encontrado no já referido terreiro da irmã de santo de pai Dary. 
religiosa da casa, sem contar os ogãs e equedes a quem, uma vez feita a confirmação, é vedada qualquer possibilidade de incorporação.

O corpo no candomblé é a morada da vida individual e das forças sagradas, mesmo que estas se manifestem visivelmente apenas em alguns momentos apropriados. Pessoas recém-saídas da reclusão, tanto equedes e ogãs como iaôs, têm que manter uma série de cuidados especiais durante longos períodos que variam de 21 dias a três meses - podendo durar até um pouco mais, caso o orixá expresse esta necessidade no jogo de búzios. Durante esse período o novo membro da casa deverá vestir-se exclusivamente de branco, cobrir a cabeça com algum chapéu, boné, lenço ou assemelhado, usar quelê e contra-egun, não poderá manter relações sexuais, nem fumar, beber ou tomar banho de mar. São os resguardos, que devem ser cumpridos à risca para não pôr em risco a saúde física e emocional do iniciado recente. Algumas destas proibições podem se estender por períodos mais longos, como a abstinência de bebidas alcoólicas e dos banhos de mar que, em certos terreiros, dura até um ano. Algumas sofrem variações de acordo com o orixá do iniciado, como Oxalá, por exemplo, que pode exigir que seu filho use branco por muito mais tempo, ou mesmo pelo resto da vida. Além disso, há as quizilas, proibições alimentares correspondentes aos orixás. Cada pessoa deverá evitar tanto as quizilas do seu santo, quantas as de sua ialorixá ou babalorixá. Estas proibições alimentares constituem um ponto interessante, pois sua quebra causa reações imediatas que, muitas vezes se parecem com uma intoxicação alimentar, podendo causar vômitos e erupções cutâneas. Assim, trata-se de um amplo conjunto de ações cujo foco central se encontra na corporalidade dos adeptos religiosos que estabelecem tanto o que os corpos podem fazer como o que não podem mais.

No entanto, é preciso ressaltar que toda esta atenção dirigida ao corpo não tem por objetivo, nem por resultado, estabelecer uma oposição entre "corpo" e "consciência”. Mesmo que a materialidade física seja tomada como "objeto" das manipulações rituais, o sen- 
tido dessas ações não se estabelece na rejeição das potencialidades corporais - embora consista numa elaborada regulação destas como algo oposto à mente ou ao espírito. Como argumentou Weiss (1999), não há razão para supor que toda atenção dirigida ao corpo seja necessariamente restritiva às potencialidades do sujeito. Não se trata, exatamente da retomada reflexiva do próprio corpo enquanto um objeto da vontade, como na análise de Giddens (1991), ao menos, não da vontade individual. Se esta atenção toma o corpo como objeto é no sentido de reconfigurá-lo para voltar-se de novas maneiras para o mundo. Mais ainda, para um mundo religiosamente constituído, no qual o sagrado tem seu lugar junto aos seres humanos, perpassando seus corpos, quer se torne visível na incorporação das divindades ou não. Este é um ponto fundamental para compreendermos a especificidade radical do candomblé. Como foi indicado de várias maneiras diferentes durante todo este trabalho, a religião aqui tratada não se assenta primordialmente sobre uma dicotomização, mas sim sobre dualidades que se completam e imiscuem umas nas outras. É preciso, no entanto, considerar mais atentamente a relação dessa particularidade com a do mundo das pessoas aqui tratadas.

Ao solicitar o engajamento corporal de seus adeptos das maneiras citadas, o terreiro de candomblé desafia muitas das fronteiras corporais presumidamente naturais para pessoas de classe média. Mobilizando todos os órgãos sensoriais e ainda avaliações muito próximas ao corpo, como a vergonha, os limites da exposição, do conforto e da destreza, além da radicalidade da incorporação do outro sagrado, esta religião desafia os limites do indivíduo social, psicológica e religiosamente. Ao fazê-lo, o candomblé estabelece simultaneamente o mundo em que tais fronteiras são reconfiguradas, uma vez que definições de interior, exterior e do que pode trespassar seus limites, do que é visível e do que deve permanecer invisível sustentam a coerência tanto da existência encarnada quanto da própria cultura. (WEISS, 1999, p. 89) O mundo - enquanto for mundo humano tal como o conhecemos - nos é dado através da sua exploração pelo corpo e, 
confrontando suas possibilidades, nos dá a conhecer ao mesmo tempo o próprio corpo.

Colocar o corpo como objeto de grande atenção é uma forma de conhecê-lo, mas isto não significa somente ter dele uma representação objetiva bem elaborada, e não é isto o que esta religião propõe. Mais ainda, conhecer meu corpo é fazer uso de suas possibilidades como minhas - pois é isto que elas são - , ter um senso do que me pertence neste mundo. As posições, reações, gostos, gestos me pertencem e têm sua unidade sustentada pelo arco intencional através do qual mantenho-me ligada a elas. Este arco que sustenta as formas de voltar-se para objetos, sendo constituído por este mesmo movimento de "atenção", refere-se à sedimentação de certas maneiras de lançar-se em ações mantidas no horizonte do sujeito. Embora, as formas de se dirigir ao entorno sejam sempre atuais, isto é, existindo no presente de sua ação, correlacionam-se intimamente com o passado e o futuro:

$[\ldots]$ a consciência se projeta no mundo físico e tem um corpo da mesma forma em que se projeta num mundo cultural e tem seus hábitos: porque ela não pode ser consciência sem contar com significações dadas tanto no passado absoluto da natureza quanto em seu passado pessoal e porque qualquer forma de experiência vivida tende para uma certa generalidade, seja aquela de nossos hábitos, seja aquela de nossas 'funções corporais'. (MERLEAU-PONTY, 1962, p. 137) ${ }^{106}$

\footnotetext{
106 É importante ressaltar que, para Merleau-Ponty, assim como para Bourdieu, a natureza não é o que jaz para além do "trabalho" da cultura, não é um mundo físico puramente objetivo independente da ação humana. A natureza é, antes de tudo, um resultado de uma sedimentação tão bem-acabada das significações que pode inclusive cumprir o papel de já dado na experiência, tal como as funções do "organismo" que, embora não existam independentes de sujeitos encarnados (concretos, culturais), permitem a coexistência de um certo nível de "processos em terceira pessoa" com a experiência pessoal. Este nível de "despersonalização" existente na vida da consciência é de extrema importância para evitar o idealismo, pois ele opera como limite concreto às explorações desta. Mais uma vez, porém, ele é dado no âmbito sociocultural, nas matrizes do habitus de Bourdieu e não numa "natureza objetiva".
} 
É preciso reiterar que essa operação sempre renovada no presente da ação não é desprovida de sentido nem mesmo nos menores gestos, uma vez que conta com o constante pano de fundo do mundo e do corpo próprio. Ao iniciar um movimento dos mais simples, como coçar a orelha, o sujeito lança-se a uma ação que tem sentido e direção: ela volta-se para um fim. Entretanto, a questão de como pode haver sentido no que é eterno fluxo e renovação pode sempre ser contraposta a esta formulação. Como argumentou Jenkins (2002) é a própria materialidade corporal e do entorno o que sustenta a permanência em meio ao movimento constante. A solidez física dos corpos e ambiente permite a sustentação dos liames intencionais que o mundo solicita em sua forma especificamente cultural de existência. Assim, as formas de voltar-se para o mundo participam da autoidentidade, pois se imiscuem na própria base das relações nas quais o "eu" se situa com relação a ele. Os modos específicos de engajamento nas ações são apropriados na identidade pessoal, de maneira semelhante à qual o habitus, por sua força integradora, constitui um estilo de vida.

No caso dos terreiros, a apreensão de gestos adequados que passam a ser executados sem reflexão tem duas consequências importantes para este argumento. A primeira é que, considerado como um espaço entre outros, a roça se torna um lugar onde se pode - e deve ir - ao invés de um lugar distante e inadequado. Neste sentido, podemos dizer que os indivíduos de classe média realizam uma verdadeira ultrapassagem de fronteiras sociais ao vincularem-se a um terreiro, especialmente àqueles que se situam em bairros mais distantes da periferia. Dessa forma, já podemos dizer que o vínculo com o candomblé "muda como a gente vê as coisas". A periferia (uma minúscula parte dela, é verdade) é apropriada pelo trânsito dessas pessoas em seu mundo mais próximo. A outra consequência é que novas formas de exploração do entorno significam novas formas de apreensão do mesmo. Como vimos acima, as possibilidades exploratórias do corpo participam do senso de unidade que possibilita a mais 
básica autoidentificação: saber que meus gestos são de fato meus. Como sustentou Jenkins (2002) é a própria solidez da corporalidade individual que oferece alguma estabilidade aos processos contínuos e sempre abertos de autoidentificação.

Assim, é possível que surjam novas avaliações e percepções no processo de autoidentificação com um terreiro, uma vez que estas emergem da prática. Ao serem apropriados pelos sujeitos, estes modos de exploração e interação passam a fazer parte de seu horizonte de possibilidades e, assim, contam como pano de fundo sobre o qual são recortados os objetos tematizados. É o horizonte que dá os contornos da figura: somente contra seu pano de fundo ela pode tornarse perceptível. Até mesmo o corpo próprio quando retomado como objeto de reflexão, passa a ter o candomblé como um de seus horizontes de sentido. Ou melhor, ele mais facilmente do que outros aspectos da vida pessoal, uma vez que muito das manipulações rituais o solicitaram e podem ser evocadas em diversas sensações, como quando da desobediência a uma quizila que provoca uma reação corporal violenta e desagradável. É dessa maneira, incorporando-se aos horizontes dos sujeitos que elementos oferecidos pelo candomblé podem passar a fazer parte de seus habitus e estilos de vida.

No entanto, não há uma "transformação total”, podemos apenas falar de uma ampliação de horizontes. Assim, as pessoas investigadas podem continuar mencionando a falta de educação, a ignorância daqueles com quem passaram a conviver, sua falta de "seriedade" ou de "sinceridade" nas relações com o sagrado e com os demais membros e, ao mesmo tempo, avaliar positivamente sua convivência no terreiro:

A questão, financeira, social, é uma outra história, mas a principal mudança, ela é interior. A forma como você vê a vida, a forma como você 'busca' orientar e conduzir a tua vida e as pessoas que te buscam. Que tipo de orientação você pode dar, né? Então, a mudança maior é essa, é interior. E essa mudança eu só vim passar, tipo um ano e meio depois da iniciação. A partir dai ela veio se aprimorando, lógico, você começa a ter contato com 'mil' pessoas dife- 
rentes, com, classes sociais diferentes, né? Enfim, culturas diferentes, hum... a espiritualidade me deu... é, um, um, vamos dizer assim, uma dádiva muito grande que foi poder ter contatos com muitas pessoas. Em outros Estados, em outros países, né? Enfim, isso abriu muito o meu horizonte, muito. A nivel de amizades fora da Bahia e, sabe? Facilitou muito o meu entendimento de universo. Que era um universo muito limitado. Hoje, eu ter uma vida que eu veja das mais diversas formas, onde você pode ir do, da alta esfera, ao, ao povo simples, que passa fome, que tem necessidades e você consegue ajudar a esse que tá cá embaixo, orientando, dando uma palavra, enfim, dando direcionamento, como você pode ajudar a esse que tá lá cima no pedestal. Então, essa coisa do convívio com pessoas das mais diversas formas, talvez tenha sido a grande mudança da minha vida. (Pai Robson, ênfases na entonação)

Irene também explicitou uma posição próxima à de pai Robson:

Então, é, eu gosto quando eu sei que eu posso chegar na academia e fazer uma fala legal sobre o meu trabalho, né? Sobre o que eu faço hoje. Mas eu sei sentar com as velhas do [terreiro], lá na beira do meio fio da porta, e sei conversar com elas de um jeito que elas me entendem e eu entendo elas, mesmo porque elas são muito mais sábias do que eu. Muito mais. Muito mais. E, por exemplo, uma, as minhas melhores amigas, eu tenho uma amiga lá no terreiro, é uma pessoa, inclusive ela é mais nova do que eu, que eu chamo ela de mãe. Porque ela ajudou muito quando eu, quando eu estava recolhida, né? O nome dela é Maria. Maria de Iansã. Maria é de muito pouco estudo, ela deve ter talvez, uma quinta série... Mas ela tem coisas tão seguras pra dizer à gente quando a gente precisa.

De maneira semelhante, vimos na fala de Ana como sua inépcia e seu desgosto puderam ser retrospectivamente avaliados como "má educação". O que não a impede de continuar "fugindo" das tarefas que a desagradam. Podemos dizer que há uma incorporação de possibilidades de apreensão, avaliação e julgamento, mas que estas não 
se sobrepõem totalmente ao habitus já incorporado anteriormente. Alguns até mesmo expressaram que sentem uma diferença na sua forma de vivenciar a religião:

Eu resolvi adotar o candomblé como uma religião. Mas eu não me vejo como um adepto, crente, é... convencional. Eu tenho uma perspectiva pessoal da religião que a própria compreensão do fenômeno religioso me posiciona de uma forma que eu acho que é original dentro dos ritos, do processo de culto e que não é de se estranhar porque um sujeito que veio chegar no candomblé depois dos 40 anos de idade, não há de ser um, um fiel por educação fundamental, né? [...] O rito é alguma coisa que precisa ser reproduzida para assegurar que a religião persista como fenômeno social, né? Então eu não posso me distanciar disso se eu tô naquele ambiente que professa essa religião. Mas eu tô numa posição que me confere uma perspectiva que eu acho que é diferente do geral dos religiosos que cresceram no ambiente do candomblé. (Ernesto)

É impossível discernir nas interações concretas aquilo já está totalmente assimilado como uma disposição incorporada e aquilo que é fruto de um esforço reflexivo no que diz respeito às avaliações e percepções. Não seria possível, por exemplo, dizer se pai Robson recebe e orienta as pessoas do "povo simples" com uma abertura que já não tematiza sua condição de classe, ou se os recebe a partir das reflexões possibilitadas pela incorporação da convivência que mencionou. De toda forma, sua prática hoje envolve a interação com um grupo muito mais amplo de pessoas, o que ele considera uma ampliação de seus "horizontes".

Outro exemplo de persistência do habitus escolar pode ser encontrado na fala de Antônia a respeito das amizades que fez no terreiro:

E ai, quando eu vi, eu tava fazendo trabalho e fui fazendo amigos. Ai outros amigos foram chegando, ai foi se formando um grupo. Quando eu vi, eu tinha um grupo de pessoas lá dentro que eram minhas amigas fora do [terreiro] também. 
E que era na maior parte, 'era' na maior parte, não. Era essencialmente pessoas de nivel universitário, intelectuais que estavam na roça. Pronto, eu fui ficando, nesse ficar eu fui suspensa. Eu fui suspensa equede de Iansã. Mas quando eu fui suspensa eu já tava 'toda', já tava toda. (ênfase na entonação)

Evidentemente, Antônia deve ter admitido a particularidade "universitária" de seu grupo de amigos por saber que minha pesquisa era sobre profissionais de classe média. Isto não significa que ela tenha inventado tal fato, mas apenas que nossa situação de entrevista pode tê-la feito refletir sobre este ponto, atribuindo-lhe uma importância que poderia não existir anteriormente. De toda forma, sua relação mais próxima com os outros membros de classe média não é excepcional para que duvidemos dela. Também no Torrundê houve uma sobreposição entre o grupo de pessoas que me eram indicadas para entrevistas por serem consideradas de classe média e um dos subgrupos internos do terreiro que é constituído por pessoas amigas entre si, algumas antes do ingresso na religião, outras que se conheceram lá. Marta e equede Hortência não fazem parte desse subgrupo, mas são mais velhas do que seus integrantes cujas idades variam entre 25 e 30 anos.

Assim, podemos concluir que através da abertura do horizonte de possibilidades - de gestos, apreciações e relações - o terreiro pode fornecer novos elementos ao habitus e aos estilos de vida de tais pessoas. Não podemos, porém, concluir que o candomblé domina completamente o estilo de vida de seus participantes. O horizonte de suas experiências de classe ainda marca muito seus esquemas de avaliação e percepção. A questão é que um estilo de vida é justamente a expressão da força integradora do habitus através da aplicação de uma mesma matriz geradora de práticas e valorações aos mais diversos campos. Desta maneira a autoidentificação com o candomblé pode trazer novos elementos a essa matriz, por exemplo, como vimos no capítulo anterior, possibilitar a categorização de outros em 
termos dos orixás de cabeça, ou manter certos cuidados com relação ao corpo e ao vestuário. ${ }^{107}$ Entretanto este processo identitário não invalida a matriz anterior.

Podemos dizer, seguindo a análise de McNay (1999), que é justamente a inadequação das disposições de uma classe média escolar à convivência no terreiro que permite a emergência da reflexividade acerca das mesmas e, ao mesmo tempo, possibilita a inovação através da incorporação de novas disposições. Assim, passar a ser de candomblé permitiria uma certa ultrapassagem das posições de classe, mas não total, como vimos nas expressões de como esta posição é sentida nas interações. Mais uma vez, trata-se de um jogo entre determinação e indeterminação, uma apoiando-se sobre a outra, sem eliminação de qualquer um dos polos. Ao mesmo tempo, é também um jogo entre reflexividade e pré-reflexividade que opera na estrutura figura-horizonte de toda percepção: é sobre um certo horizonte que podem ser tematizados os objetos. Estes, porém, quando não tematizados se "retraem", mas permanecem disponíveis como horizonte para novas objetivações.

\section{PARTICULARIDADES INCORPORADAS}

Há ainda um ponto que merece receber alguma atenção. Se os orixás contam como agentes, podem compartilhar certas características com os outros (os seres humanos) com os quais coexistem neste universo cultural. Estas residem tanto em "traços de personalidades" quanto - ou ainda mais - em seus modos de agir. Sob este aspecto, as divindades são altamente pessoais, particularizadas. Por outro lado, como vimos anteriormente, uma concepção bastante difundida afirma que os orixás são energias da natureza. Nunca foram seres vivos nesta terra, portanto não são mortais. São entidades cósmicas - cada uma corresponde à energia de um elemento natural - que

107 No candomblé a cor negra para roupas é considerada como inadequada e a branca a mais correta. Por isso é muito comum que adeptos desta religião evitem indumentárias de cores escuras e mantenham um guarda roupas em tons claros. 
são individualizadas na iniciação, recebendo um nome próprio e uma morada no assentamento pessoal do iniciado, o ibá.

Por este ângulo, as divindades apresentam um caráter universal e não de referência a um passado pessoal ou coletivo, etnicamente ou localmente definido (PRANDI, 1999), exceto por aquele que se encontra estabelecido na tradição ritual de cada família de terreiros e que, por sua vez delimita as experiências com as divindades. Hervieu -Léger (1998, p. 216) propôs que nas sociedades "complexas” as comunidades de fé têm a base de sua memória coletiva assentada sobre um ato fundacional - uma nova revelação - , uma vez que se rompeu o vínculo entre o passado da coletividade religiosa e a própria criação do mundo tal como conhecemos. Isto pode ser aplicável aos grupos protestantes, bem como a todos aqueles que se assentam sobre uma "verdade revelada", o que dá amplo espaço para a figura de um profeta fundador, mas não é o caso do candomblé, cuja reivindicação de verdade se assenta a própria criação do universo que coincide com a criação dos orixás. O candomblé é a religião de culto a forças da natureza e, portanto universais. Entretanto, os modos “corretos" de culto (e até mesmo quais entidades devem ser cultuadas) são objeto de disputa entre diferentes linhagens de terreiros, o que os aproxima um pouco da proposição de Hervieu-Léger (1998). Desse modo, mais uma vez o candomblé parece apresentar os dois polos de uma dualidade: uma ontologia universalista e uma prática particularista. Mais uma vez é preciso retornar aos orixás para compreender a direção do processo.

Como vimos, os orixás são considerados como energias da natureza que dominam a vida de cada ser humano independente do conhecimento deste, e ao mesmo tempo, como a relação mais individualizada que mantêm com cada membro iniciado. Assim, os deuses expressam ao mesmo tempo a mais ampla generalidade, que diz respeito ao cosmos e a toda a humanidade, e a maior particularidade, tornando-se individuais na iniciação de seus filhos. O que os orixás mani- 
festam quando incorporados não é o poder de um passado específico de um grupo, mas forças cósmicas. ${ }^{108}$

No contexto de Salvador, as divindades não apresentam o caráter de ancestrais bem definidos, de familiares ou chefes políticos divinizados. Aqui, existe a ideia de que certos indivíduos podem ter orixás herdados de seus ascendentes, mas esta concepção não é bem sistematizada entre os entrevistados, como já foi mencionado:

Marta - Mas meu pai Dary fala de um orixá de ancestralidade, e ai ele fala, assim, nessa coisa de que a minha Oxum é de uma, hierarquia muito velha, muito...

Luciana - Antiga?

Marta - Não que ela seja velha, mas é de uma...

L: A linhagem dela?

M: A linhagem dela é muito antiga, e não sei o que, pererê, não é assim tão fácil aqui. Mas eu não sei se... tanto que a minha irmã ficou de encontrar, tá procurando lá essa única foto que a gente tinha da minha avó no candomblé, pra gente poder ampliar e começar a identificar, pela roupa, pelas contas...

L: Ah! De que orixá ela era...

M: Pra ver se a gente consegue. É. Porque a gente não tem essa...

L: Nenhuma?

M: Não tem, não tem. Mas parece que essa minha Oxum é, eu não sei se... se ela não, pra mim ela vem da minha vó, vem da, vem desse lado de minha vó.

Através de reticências, retomadas, hesitações, Marta tentava me explicar como compreendia sua ancestralidade no candom-

108 Quanto a isto, é imprescindível ter em mente que a quase totalidade do trabalho de campo para esta pesquisa foi realizado num terreiro aberto pelo seu atual líder (isto é, que ainda não atravessou gerações de adeptos de modo a conformar uma memória coletiva de um passado altamente valorizado) que vem de uma família católica e espírita, sem "raízes" conhecidas no candomblé. Talvez seja possível encontrar concepções muito distintas em terreiros antigos. 
blé. Tentei trabalhar esta questão tanto com os entrevistados negros quanto brancos, mas todos permaneceram no mesmo nível de indefinição e hesitação. É interessante notar que Marta, não apenas é negra como tem antigas relações com movimentos negros. Mesmo assim, não emergiu uma forte correlação entre seu orixá pessoal e o pertencimento a um passado coletivo. É bastante provável que este seja um tema mais sensível que exige uma aproximação mais cuidadosa. É também de se imaginar que numa pesquisa conduzida nos terreiros "tradicionais" a questão da ancestralidade que vincula o indivíduo ao candomblé surja com força. No entanto, para essas pessoas de classe média cujas famílias não frequentavam a religião, o caso parece manter-se no nível de uma indefinição como a de Marta, pois mesmo entre Irene, Ernesto e Antônia, pessoas negras e membros de um terreiro antigo e considerado muito "tradicional”, não encontrei ressonância à questão.

Pode-se, então, dizer que o candomblé não oferece - ao menos para os adeptos de classe média - um palco para a elaboração de identidades coletivas bem definidas, pois não faz referência a uma história de um grupo bem delimitado. Evidentemente isto pode ser relacionado à história da escravização dos negros africanos e da reorganização de suas identidades em outro contexto sociocultural. (PRANDI, 1999) Num outro nível, pode ser relacionado à separação entre culto aos orixás e culto aos antepassados, baba Egun. Em ainda outro, pode ser relacionada organização descentralizada que mantém cada terreiro autônomo frente aos outros. (FRIGERIO, 2003) Por ora, no entanto, posso dizer que esta é uma religião que se volta para toda a humanidade e apresenta suas divindades como energias cósmicas.

Os orixás, portanto, não se apresentam como atualização do poder do passado de um povo concreto, mas e os caboclos? É interessante notar que estes vêm ao aiê para aconselhar, abençoar e tratar de seus seguidores. Mais ainda, os caboclos arranjam-se em categorias relacionadas a personagens da história brasileira. São os índios, donos originais desta terra (SANTOS, 1995), são os boiadeiros desbravadores dos sertões, são os marujos que atravessaram os mares. Dessa forma, 
assemelham-se às famílias de espíritos correlacionadas por Stoller (1997) à experiência histórica Songhay. Aproximam-se também do surgimento de uma categoria de espíritos, analisada por Ferrándiz (2004), no culto venezuelano María Lionza. Na década de 1990, num período de intensificação da pobreza e da violência urbana, esta forma de espiritismo (parecida com nossa umbanda) viu surgir a figura do Malandro - espíritos de jovens mortos violentamente, em geral ligados ao tráfico de drogas. Tal como os Hauka, os Malandros apresentavam uma face assustadora e, ao mesmo tempo, ofereciam proteção aos humanos envolvidos no culto. De modo semelhante ao de Stoller, Ferrándiz analisou a emergência destas entidades como uma forma encarnada de lidar com transformações sociais, evidenciando o caráter "histórico" das divindades.

Enquanto o poder dos orixás parece dizer mais respeito à existência universal, do mundo e do ser humano, o dos caboclos parece referir-se mais diretamente à particularidade de uma experiência histórica e, neste sentido, é interessante notar que, no dizer geral, “o caboclo vem para trabalhar". Ao que tudo indica, para uma ampla gama de adeptos do candomblé, o poder dos caboclos é mais diretamente sentido em suas vidas. Também é interessante a menção a um "Egun caboclo, baba Iaô" no culto a baba Egun de Ponta de Areia (Ilha de Itaparica) que encerra a festa e para o qual se canta em português e é um dos Eguns "mais festejados” daquele terreiro. (BRAGA, 1988a, p. 214)

Este é um ponto de contraste importante entre os membros das camadas populares e os adeptos de classe média que acompanhei. Como já foi dito, no Torrundê há culto aos caboclos e estes permanecem sempre como uma possibilidade para os filhos da casa. Boa parte daqueles focalizados nesta pesquisa de fato incorporam seus caboclos nas seções quinzenais. Mesmo assim, esta entidade não surgiu nas entrevistas com tanta ênfase como os orixás. Isto parece indicar, ao mesmo tempo, que a experiência histórica encarnada pelos caboclos encontra menor ressonância em suas vidas - ou encontra outras for- 
mas de atualização - e que a concepção das divindades como forças cósmicas individualizadas combina melhor com seu universo experiencial. A conclusão disto é que as próprias divindades encontramse enredadas no contexto social em que encarnam.

Isto, porém, não é o mesmo que dizer o "que está por trás da incorporação" dos orixás. Não é preciso descrer delas para fazer uma afirmação deste gênero. O ponto desta última análise é que o movimento exploratório pelo qual sujeitos engajam-se em seu mundo, constituindo simultaneamente este mundo e a si mesmos como sujeitos, é o mesmo que constitui as divindades enquanto tais. Isto significa que tal movimento informa um modo de voltar-se para as divindades, de relacionar-se com elas que as situa tanto quanto os indivíduos encontram-se situados socialmente. No mesmo sentido, podemos dizer que os orixás, ao existirem simultaneamente no mundo material e espiritual, têm que assumir uma forma de engajamento no primeiro quando encarnam em seus filhos. Ao incorporar nos iniciados, os orixás compartilham com eles uma forma de estar no mundo, de maneira semelhante à que Fábio utilizou para explicar como o orixá, ao ceder sua energia ao seu filho, cede também algumas de suas características. E neste mundo de classe média a individualidade é uma das formas de engajamento mais atuantes. 


\section{Conclusões: retomando argumentos}

O objetivo deste trabalho foi apresentar uma análise das trajetórias de autoidentificação de profissionais de classe média com o candomblé que pudesse considerar tanto o desenrolar dos processos identitários quanto elementos específicos da posição de classe e da religião particular enfocada. Para tanto, foi proposta uma abordagem teórico-metodológica que não estabelecesse correlações unilaterais entre classe, religião e identidade pessoal. Embora a exposição tenha sido iniciada por um quadro bastante esquemático sobre a cidade de Salvador apoiado sobre alguns dados estatísticos e características peculiares bastante evidentes, além de um breve panorama da situação econômica - logo me voltei para uma descrição sucinta dos perfis dos entrevistados e suas trajetórias religiosas. Somente depois deste prólogo o leitor foi introduzido à discussão da construção de classe social, na qual procurei justificar uma abordagem que integre tanto a posição numa situação de mercado quanto a questão do prestígio envolvido nas distinções de tais posições. A análise foi elaborada a partir das proposições de Max Weber e Pierre Bourdieu porque são perspectivas que procuram englobar as relações na esfera da produção e o mundo de significados em que pessoas concretas vivem. 
Os conceitos de prestígio, habitus e estilo de vida orientaram o recorte de classe. Dessa forma, procurei manter a referência à posição ocupada na esfera da produção numa situação de mercado de trabalho como uma das bases analíticas. É importante destacar que a abordagem proposta procurou ser inclusiva, agregando perspectivas e não eliminando umas em favor de outras. A classe média apresentada foi, então, recortada tanto em relação à esfera econômica quanto em relação ao prestígio diferenciado de cada posição. Procurei correlacionar sua posição atual, embora sucintamente, com a composição da estrutura de seu capital - são detentores de capital cultural relativamente maior do que econômico - e dar alguns indícios de sua trajetória de classe. Vimos, então, que os entrevistados com mais de 40 anos possuíam capital escolar mais elevado do que seus pais, enquanto que os com menos de 40 encontravam-se em posição semelhante. Financeiramente, porém, ambos os grupos encontravam-se estagnados ou em ligeiro declínio com relação à geração anterior, o que não diferia da situação da classe média brasileira em geral, anterior ao governo Lula, quando a pesquisa foi realizada. Curiosamente, ao atualizar alguns dados estatísticos referentes à renda e ao emprego formal para esta edição, utilizando dados disponibilizados a partir de 2010, não foi possível identificar alteração da posição das pessoas aqui retratadas com relação ao conjunto das camadas intermediárias da população, o que seria de se esperar frente à suposta formação de uma "nova classe média” brasileira. Contudo, qualquer conclusão a este respeito seria leviana, uma vez que isto não consistiu num dos objetivos deste trabalho.

A grande vantagem dos conceitos de habitus, estilo de vida e prestígio para a análise de classes sociais reside exatamente em evitar a dicotomização do mundo social entre relações objetivas e avaliações subjetivas, mostrando como ambas as perspectivas estão profundamente imbricadas na constituição do universo humano da ação. De acordo com tal ponto de vista, procurei mostrar quais são, para os próprios entrevistados, os marcadores de distinção de classe. 
Não é possível comparar estilos de vida sem uma grande massa de dados que possam ser postos em relação às classes de agentes, pois o conceito refere-se a esquemas de percepção que integram práticas distintas como pertencentes a um "conjunto". Mesmo assim, procurei dar algumas indicações de alguns elementos relevantes no cotidiano dos pesquisados. Evidentemente, isto poderia ser feito apenas depois que o leitor tivesse uma ideia, ainda que muito resumida, dos contextos sociais das práticas de tais pessoas e de alguns valores e noções amplamente difundidos. De forma geral, procurei construir um quadro de alguns aspectos de suas práticas religiosas, escolares e profissionais visando encontrar uma maneira de ressaltar o posicionamento social dos sujeitos pesquisados que permitisse uma aproximação não redutora ao âmbito de sua ação. A partir daí pude colocar a questão de como se desenvolveram as relações entre membros de uma classe social particular com esta forma de religiosidade.

Para prosseguir a análise, então, foi necessário procurar estabelecer algumas bases sobre as quais destacar as especificidades próprias a esta religião afro-brasileira. A orientação fundamental para este procedimento foi retirada da sociologia da religião weberiana. Desse modo, efetuei uma breve aproximação entre tipos ideais de aspectos religiosos (referentes, sobretudo, aos valores sagrados e à fonte de legitimidade da autoridade, mas também às diferentes formas de participação no grupo) e o candomblé. O procedimento revelou que esta religião comporta elementos marcantes de diferentes tipos de religiosidade, embora haja um forte acento em seu aspecto carismático, sobretudo no que diz respeito à autoridade suprema dos terreiros. No entanto, esta perspectiva exige que consideremos também aqueles indivíduos para quem a religião dirige suas proposições, as camadas "leigas" cuja importância é fundamental para o desenvolvimento histórico das diferentes religiões. (WEBER, 1974b; 1991; 1996) Embora o termo "leigo" não se aplique muito bem aos membros dos terreiros do candomblé, já que todos eles são envolvidos na "produção" religiosa, eles podem ser analiticamente 
considerados como tal. Assim, voltei-me para as experiências religiosas possíveis no culto, âmbito no qual a ambiguidade tipológica torna-se mais acentuada. O candomblé surgiu, então, como uma religião que possibilita formas distintas de inserção no grupo e de experiências do sagrado, o que, argumentei, pode ser um dos maiores atrativos que vem exercendo sobre pessoas de classe média.

A partir daí, foi necessário elaborar a questão da formação de identidades pessoais no âmbito religioso procurando manter, como pano de fundo, o posicionamento social dos sujeitos. Mais uma vez, o esforço de exposição deu-se no sentido de agregar perspectivas. Como vimos, as identidades podem ser pensadas em vários níveis analíticos que não se excluem mutuamente. Um enfoque interacional oferece maior destaque ao fato de que as identidades - pessoais ou sociais - constroem-se num jogo de aproximações e contrastes com outros. Este ponto é relevante não somente para evitar a reificação do conceito de identidade - como se estas constituíssem uma espécie de instância mental sobre si mesmo - mas também por abarcar o âmbito da ação em sociedade, chamando atenção para o caráter compartilhado e instável do universo de sentidos no qual se desenrola a vida cotidiana. Apontando para o constante jogo entre diferentes ênfases às quais os sujeitos recorrem na interação, esta perspectiva também põe em destaque o caráter processual das identidades, pois estas nunca se cristalizam em torno de um conjunto de atributos. Dessa forma, trajetórias de autoidentificação podem ser vistas como um contínuo "posicionar-se" nas interações, e não exatamente como um percurso bem definido. Não se trata de uma mobilidade de um ponto a outro, mas sim de um processo cuja característica principal é manter uma abertura e, ao mesmo tempo, continuidade.

As trajetórias de autoidentificação envolvem um componente reflexivo: a retomada constante do próprio passado na interpretação dos posicionamentos atuais. Giddens (1991) enfatizou que esta retomada, na contemporaneidade, ganhou status de disposição permanente dos sujeitos sociais. Sua própria formulação já indica, 
então, a necessidade de alargamento da abordagem teórica para além dos processos reflexivos. Disposições permanentes são incorporadas de modo a atuar sem qualquer esforço reflexivo. (BOURDIEU, 2001b 2003, p. 172-173) Por seu turno, considerar que as identidades pessoais atuam tanto no esforço refletido de retomada constante das próprias posições quanto nas disposições que lhe são subjacentes exige que a análise englobe também a dimensão encarnada dos sujeitos - locus da incorporação de disposições. Caso contrário, corre-se o risco de perder de vista toda a agência dos sujeitos, que emergem na análise como matéria inerte para as inscrições culturais: todo o sentido possível para suas ações estaria dado nas representações socialmente construídas e nunca no próprio desenrolar da ação. Esta postura pode ser aproximada àquela que considera o sentido como emergente da retomada posterior dos eventos na narrativa. No entanto, o próprio desenrolar da ação não se dá em meio ao caos e os autores aos quais recorri enfatizam este ponto, com ênfases um pouco distintas, mas não divergentes.

Budgeon (2003) enfatizou a necessidade de se levar em conta a encarnação (embodiment) para a compreensão de como pessoas ativamente retomam representações e valores, não apenas incorporando-os, mas também negociando-os, isto quer dizer que há uma verdadeira apropriação: uma incorporação negociada que as torna próprias. Jenkins (2002) argumentou que a própria corporalidade dos indivíduos - e a existência física de seu entorno - constitui uma base de continuidade sobre a qual emerge a identidade e sua constante reformulação. Merleau-Ponty (1962) investigou as minúcias da atividade exploratória dos sujeitos num mundo compartilhado, isto é, cultural e socialmente constituído. Voltar-se para o mundo - condição de existência dos seres humanos - é uma dimensão carregada de sentidos, mesmo antes que estes sejam tomados por um processo de objetificação, ou seja, tematizados como objetos de pensamento. Weiss (1999) incorporou estas análises para investigar a flexibilidade inerente à apropriação de valores e afetos socialmente difundidos. 
Bourdieu (1999a, 1999b, 2001b, 2003) acentuou o permanente posicionamento dos sujeitos e suas práticas num espaço social impregnado de distinções lógicas e de poder. Assim, procurei retomar uma descrição etnográfica que levasse em conta o caráter fundamentalmente encarnado dos sujeitos em seus contextos de interação.

Para Weber (2006), o próprio objeto da sociologia é constituído pela compreensão dos sentidos das ações sociais. Dessa maneira, a questão inicial da pesquisa, proposta com base nas formulações deste último, foi sendo ampliada sem que isto significasse o abandono de sua perspectiva analítica. O objetivo teórico-metodológico deste trabalho, portanto, foi argumentar em favor de uma investigação inclusiva, que procurasse englobar maneiras complementares de construção de um objeto de estudo. A questão inicial sobre "como indivíduos das camadas médias reelaboram as proposições do candomblé”, foi sendo ampliada de modo a constituí-los como uma classe social - sem desconsiderar sua posição de grupo de status - e abarcar as consequências da adesão a esta religião para seu modo de viver.

Evidentemente, a abordagem aqui proposta não esgota a compreensão do objeto que construiu. Muitos outros aspectos dos processos de autoidentificação de pessoas de classe média com o candomblé podem ser acentuados. Outras correlações podem ser enfatizadas, a partir de ângulos distintos. É importante deixar claro que propor uma análise inclusiva não significa procurar dar conta de todas as possibilidades. Isto seria pressupor que o objeto de estudo tem uma existência autônoma com relação à construção teórica e que basta focalizá-lo de todos os ângulos possíveis para descrevê -lo. Da mesma maneira como não existem objetos "naturais" para a percepção, que é sempre chamada à "completá-los" ativamente (MERLEAU-PONTY, 1962, p. 361), não existem objetos totalmente constituídos sobre os quais se debruçaria a análise. Dessa forma, o que procurei apresentar foi um conjunto de aspectos do objeto de estudo que permita situá-lo no mundo da ação humana, apresentar alguns de seus possíveis sentidos. Nenhuma perspectiva teórica 
é completamente verdadeira, tampouco totalmente falsa, segundo Merleau-Ponty (1962), desde que tenhamos em mente a profunda imbricação entre aspectos econômicos, morais, históricos, uma vez que nenhum ponto de vista pode esgotar o objeto que apresenta.

\section{ALGUNS PONTOS ESPECÍFICOS AO OBJETO}

Já no início da análise das trajetórias religiosas desenvolvidas por estas pessoas de classe média, um dos primeiros pontos recorrentes que desperta a atenção é o fato de que, embora algumas delas tenham iniciado seu contato com um terreiro em busca de soluções para problemas pessoais, todas as demais foram movidas pela curiosidade, o que algumas chamaram de um "interesse cultural". Robson, Francisco e Marta, porém, apresentaram uma união dos dois fatores. O primeiro foi assistir a um ritual, não gostou, mas retornou em busca de solução para seus problemas financeiros e afetivos. Os outros dois começaram a ir aos terreiros apenas para conhecer, logo depois adoeceram e procuraram apoio na religião. Mais interessante ainda é que, apesar dessa curiosidade, nove dos 15 entrevistados permaneceram visitando somente um terreiro e começaram a frequentar outros apenas depois de iniciados, em companhia de irmãos ou dos líderes de suas casas.

Estes últimos surgiram como as figuras mais importantes no processo de adesão, já que todos os entrevistados desenvolveram um vínculo afetivo com a ialorixá ou o babalorixá de seus terreiros, o que, na verdade, é bastante usual. Entretanto, a amizade inicial com os líderes da casa, neste caso, foi um dos motivos mencionados para a adesão e se contrapõe ao distanciamento com relação aos demais membros, situação bastante diferente daquela encontrada por Rabelo (2008) nas trajetórias de adeptos de camadas populares em Salvador. No caso aqui trabalhado, muitas vezes, esta amizade já existia e foi o motivo dos primeiros contatos com o candomblé, como para as equedes Hortência e Helena, por exemplo. Em outras, foi decorrente da curiosidade inicial o motivo de adesão. A abordagem através de múltiplas perspectivas, porém, permitiu evidenciar sentidos que se superpõem na 
vida cotidiana. O elemento que emergiu, inicialmente, como motivo de adesão é o mesmo que elucida umas das dificuldades nas interações no terreiro quando focalizei especialmente a apropriação do gestual adequado no último: há uma tensão entre a postura adequada frente ao superior religioso e as disposições exigidas à interação com um "amigo".

A convivência na roça os colocava diante de uma série de outros desconfortos e conflitos. Embora as intrigas e desavenças sejam corriqueiras entre adeptos de qualquer classe social, há dois pontos de interesse aqui. O primeiro deles correlaciona-se com a falta de familiaridade com as regras do candomblé, sobretudo com sua hierarquia e com os gestos que a expressam, o que muitas vezes colocou as pessoas aqui consideradas em situações desagradáveis e exigiu delas um esforço de aprendizagem, ou mais especificamente de apropriação reflexiva das disposições adequadas. O outro ponto, de maior relevância, é que os conflitos enfrentados são sentidos como uma "invasão de privacidade" e como uma ultrapassagem dos limites esperados para relações num ambiente religioso. Os entrevistados desenvolveram uma atitude mais fechada em relação aos outros participantes e raramente mantiveram laços de amizade que extrapolaram o ambiente da roça. Nos casos em que isto ocorreu, as relações geralmente se limitaram aos adeptos que, tal como eles, tinham nível universitário, eram profissionais de carreira e apontados como de classe média. É o que vemos entre o grupo de entrevistados jovens do Torrundê e o grupo formado por Antônia, Ernesto, Irene e João Alfredo, no outro terreiro.

Estas pessoas não chegaram ao candomblé levadas por familiares, exceto Paulo, que era criança, e Rosana. Quem cumpriu este papel foram colegas de trabalho e estudo ou amigos. Com isto, suas relações com o terreiro colocaram-se em outro âmbito e muitas vezes foram motivo de confrontos no interior das famílias, que reagiam negativamente ao envolvimento destas pessoas com a religião. Hoje, tal atitude é interpretada pelos entrevistados como fruto do 
"preconceito" e da "ignorância" de seus familiares quanto à "verdadeira" natureza do candomblé. Talvez a religião vivida em contraposição à família favoreça a rejeição do controle do comportamento pelos demais membros do terreiro e a sensação de "invasão de privacidade" provocada pelas fofocas, acirradas ainda mais pelas diferenças de condições socioeconômicas no interior do grupo de culto. Assim, há já aqui um espaço para que a trajetória religiosa que leva ao terreiro seja pensada como opção individual. É importante destacar que entre estas pessoas não emergiu o discurso da "necessidade" da iniciação, muito comum entre adeptos cujas famílias mantinham-se próximas à religião. Mesmo admitindo que exista um "chamado do orixá", que os participantes são "escolhidos” pelas divindades, as pessoas de classe média que pesquisei sentiam que sua relação com elas deu-se por livre e espontânea vontade, como vimos em várias passagens. A ênfase na ideia de que a religião seguida é fruto de uma opção individual é um dos elementos mais relevantes que surgiu da análise das trajetórias das pessoas pesquisadas. Sua importância está muito mais no fato de que permite considerar a inter-relação entre autonomia do sujeito e as influências contextuais também admitidas voluntariamente, que é expressa muitas vezes no vocabulário da agência das divindades e da influência familiar.

Esta ideia de que o candomblé foi a religião escolhida por vontade própria encontra seu corolário no exclusivismo religioso expresso pelos pesquisados. Em seu entender, distintas práticas religiosas não combinam entre si para formar um estilo pessoal de espiritualidade. Este exclusivismo institucional, porém, não significa que eles não recorressem a ideias de outras vertentes religiosas, em especial do espiritismo kardecista, e termos como mediunidade, evolução e crescimento espiritual apareceram em várias das entrevistas. De toda forma, sua prática religiosa manteve-se vinculada a um grupo apenas. Mais uma vez reencontramos a temática da manutenção de duas tendências teoricamente opostas. Nesse sentido é importante ressaltar que o vínculo religioso exclusivo pode estar efetivamente relacionado 
a certas expectativas de coerência interna às concepções e práticas religiosas (SILVA, 1999), que também foi manifestada por muitos dos envolvidos. É importante reiterar que a expressão de certas tendências nos discursos e comportamentos não significa que estes se tornem homogêneos e lineares. Ao contrário, um certo nível de ambiguidade parece ser característica marcante da vida concreta e boa parte do esforço analítico desenvolvido neste trabalho se voltou para a manutenção de possíveis dualidades e imprecisões.

Portanto, podemos concluir que uma das características marcantes das trajetórias religiosas que levaram estas pessoas ao candomblé está na ideia de que a religião foi um ato de escolha própria, pelo qual se enfrenta a família - e às vezes preconceitos em outros ambientes, como o de trabalho - e se expressa na manutenção de um vínculo exclusivo. Tais elementos permitem à pessoa traçar uma distinção frente ao ambiente familiar e à sua classe. Este ponto apresenta um contraste com os casos de indivíduos cujas famílias pertenciam ao candomblé, o que não lhes permite operar uma distinção com base religiosa e para os quais o discurso do "chamado" do santo e da "necessidade" é recorrente.

As concepções relatadas acerca do desenrolar da trajetória religiosa são replicadas na esfera escolar e profissional. Sobre este ponto encontrei a mesma ideia de que a ocupação exercida é resultado de uma escolha individual. Também neste aspecto a influência de fatores externos à vontade individual foi admitida sem que implicasse numa diminuição da ênfase na opção pessoal, no gosto e no prazer de exercer a ocupação escolhida. Boa parte da vida cotidiana dos pesquisados foi - e continua sendo - articulada em torno do estudo e do trabalho, e é interessante notar que, ao me sugerir outros possíveis entrevistados, eles apontavam exatamente a profissão e a escolarização como justificativa. No entanto, o que chamou a atenção foi que a maneira pela qual os indivíduos analisados expressaram distinções entre pessoas de diferentes classes assenta-se sobre a ideia como "educação" e "cultura". Como vimos, estas abrangem tanto a 
educação formal, a polidez, quanto uma certa "moralidade" no uso da linguagem, nos gestos e no comportamento no ambiente do terreiro. Religião não combina com "paquera”, o que é condizente com o fato de que o terreiro não representou para os entrevistados uma grande possibilidade de ampliação das relações sociais. Aqui se apresenta novamente a necessidade de nuançar a afirmação. Dois pontos não podem ser desconsiderados.

Em primeiro lugar, a frequência ao grupo religioso possibilita o alargamento dos contatos e das relações de amizade. No entanto, para os membros da classe média escolarizada estas se restringem quase totalmente a pessoas da mesma posição social. Ou seja, indivíduos que poderiam vir a se encontrar independentemente da opção religiosa. Talvez isto esteja na base do fato de que, apesar de recorrer ao terreiro em busca de auxílio, os adeptos de classe média não sentem que a comunidade de culto lhes ofereça uma rede de apoio. Ao contrário, a convivência próxima foi avaliada negativamente pelas pessoas estudadas em quase todas as circunstâncias. Isto nos leva ao segundo ponto, que apenas aparentemente contradiz o primeiro. Apesar desta ênfase nos problemas e desconfortos da convivência, muitos dos entrevistados referiram-se a uma "ampliação de horizontes" que o candomblé lhes possibilitou. Mais uma vez, retomo a opção teórica que permeia este trabalho e segundo a qual a vida concreta admite e suporta ambiguidades. Dessa forma, recuperei a questão do alargamento de possibilidades no último capítulo, procurando mostrar como a própria encarnação dos sujeitos nos contextos de ação envolve esta ampliação. Ao invés de uma contradição entre "fato" e "consciência", este desencontro de afirmações foi analisado como um modo de voltar-se para o mundo das interações sociais no qual o sujeito posiciona-se como "indivíduo", isto é, dotado de autonomia e interioridade. O "individualismo" surge, então, como um acento moral e afetivo nas relações com o entorno, mais do que como "representação" das relações sociais. Assim, a convivência num ambiente diverso de sua formação familiar e escolar possibilita a emer- 
gência de novos pontos de vista, de outras formas de "voltar-se para o outro", ao mesmo tempo em que a retomada reflexiva de si mesmo na narrativa mantém o foco na individuação. A identidade pessoal, então, encontra a durabilidade das disposições incorporadas, do habitus, e se desenrola em processos ambíguos e revisáveis nas perspectivas dos diferentes contextos.

O passo seguinte foi procurar delimitar algumas especificidades da instituição religiosa analisada, visando correlacioná-las com as particularidades da posição de classe. Neste sentido enfatizei que o candomblé comporta possibilidades de inserção e participação que remetem a tipos ideais distintos. O valor sagrado supremo aponta para a legitimação carismática da autoridade (assentada sobre o princípio do axé do orixá como fonte de poder do líder do terreiro), mas esta é conjugada com a legitimação burocrática (expressa na distribuição de cargos e na importância de seu reconhecimento público) e mesclada com uma legitimidade tradicional, onde emerge o peso da filiação a certas ortodoxias e da reprodução das práticas rituais e das relações afetivas marcadas pela nomenclatura do parentesco, além da ênfase no princípio de senioridade. Isto reverte na existência de possibilidades distintas de experiência religiosa no interior de um mesmo grupo de culto. Ao considerar a inserção religiosa também do ponto de vista das experiências possíveis a seus adeptos, concluí que a própria possibilidade de experiências distintas pode ser um forte atrativo para estes membros de classe média escolarizada cujas expectativas quanto às práticas religiosas não são bem definidas, admitindo tanto a alta racionalização das normas e procedimentos quanto experiências místicas variadas e formas institucionais distintas, embora possam existir algumas tensões internas às elaborações individuais efetuadas. Como já foi reiterado, um dos pontos especialmente apto a permanecer em tensão diz respeito à legitimação carismática da autoridade que confronta expectativas de racionalização das regras e as disposições acerca das relações de amizade. 
No caso do candomblé, a própria "construção ritual da pessoa" (AUGRAS, 1983; GOLDMAN, 1985; NICOLAU-PARÉS, 1997) reforça esta atração. Segundo as concepções religiosas as pessoas não nascem "prontas", têm que ser "feitas", o que se dá num entrecruzamento de diversas relações com diferentes entidades. Desse modo, o processo iniciático estabelece uma individualização espiritual, no sentido de que cada ser humano é único em sua rede de vínculos com o sagrado, não confrontando o acento "individualista" da relação sujeitomundo. Podemos ainda considerar a iniciação como um processo que despe os novatos de suas posições e atributos sociais (TURNER, 1974) e os reconstrói na referência ao mundo sagrado (SEGATO, 1995), enfatizando sua aptidão para efetuar uma distinção intraclasse das pessoas iniciadas. Ao mesmo tempo, as próprias divindades são individualizadas no mesmo processo, ao deixar de ser a energia genérica da natureza e ganhar um nome próprio e uma residência no assentamento, o que reforça a necessidade de se considerar também a esfera do "simbólico" como imiscuído e constituído na ação. No Torrundê se diz que o orixá tem três moradas, a natureza, o ori e o ibá. Para que a relação de uma pessoa com seus orixás mantenha-se equilibrada é necessário que os três elementos estejam interligados pela iniciação. Portanto, o candomblé pode oferecer à classe média escolarizada uma forma de singularização que distingue frente à família e frente à classe social e poderia atuar como "solvente" (PIERUCCI, 2006) nessa camada social específica. Esta possibilidade pode ter um efeito altamente atrativo para pessoas que compreendem a si próprias como indivíduos que "optam" por suas religiões, profissões e "carreiras" em geral. Além disso, o processo singularizador em mão dupla, operado pela iniciação, evidencia que é preciso considerar simultaneamente a constituição social dos sujeitos e a constituição do mundo através de seu agir.

A ideia de escolha própria é importante para a compreensão dessa constituição. Vimos que mesmo os entrevistados que iniciaram um contato com o terreiro por "necessidade", isto é, para jogar búzios e 
realizar ebós por questões de saúde ou problemas familiares, mesmo assim interpretam seu ingresso no grupo de culto como uma opção própria. Este ponto foi reiterado diversas vezes dada a ênfase posta pelas pessoas analisadas na ideia de que a religião é algo que se faz de livre e espontânea vontade. Isto é menos evidente no caso daqueles que começaram a frequentar festas ou procuraram uma consulta por curiosidade ou interesse cultural. Como eles não precisavam dos serviços religiosos, parece apenas "lógico" que procurassem um terreiro movidos exclusivamente por seu desejo. Entretanto, como mostram os casos de "necessidade", esta ideia não é uma mera consequência da situação pessoal, mas uma forma bem difundida de orientar a retomada da própria trajetória. Disso decorre que a ênfase na "opção" pode ser considerada como parte do habitus dos sujeitos pesquisados.

Procurei, então, levantar algumas particularidades das interpretações religiosas efetuadas pelos entrevistados e examinar mais de perto sua participação nas atividades da roça. Mais uma vez, enfatizei que não é possível descrever tais reelaborações como um apanhado homogêneo e totalmente coerente, muito embora haja um esforço interpretativo neste sentido por parte dos adeptos de classe média. Assim, as expectativas de racionalização não entram em choque com a possibilidade do transe, uma vez que não se aplicam a este nível da prática religiosa. Ao invés de encarar a incorporação dos orixás como uma experiência religiosa irracional, fez muito mais sentido recolocá-la entre as possibilidades de experiência oferecidas - e altamente regulamentadas, como mostram as análises de Bastide (2001), Goldman (1985) e Nicolau-Parés (1997) - pelo candomblé. Desse modo, mais uma vez a análise retornou à questão da atração que esta religião pode exercer sobre pessoas de classe média justamente por oferecer possibilidades de experiências religiosas distintas.

No entanto, há um âmbito em que as tensões entre o esforço de racionalização e a prática nos terreiros se fazem sentir com evidên- 
cia: a hierarquia religiosa. Ficou claro que as dificuldades apresentadas pelos entrevistados não eram decorrentes apenas do desconhecimento das regras hierárquicas, e sim de seu fundamento carismático. Aqueles que se encontram no topo da gradação de poder têm a prerrogativa de estabelecer normas, isto é, os pais e mães de santo são as autoridades incontestáveis em suas roças. Desse modo, nem sempre a regra geral opera de fato e inúmeras exceções têm lugar no cotidiano. Este é um ponto de tensão para as pessoas pesquisadas e se traduz em esforços e anseios quanto à normalização de procedimentos, na expectativa de maior controle externo ou no abandono do terreiro, como no caso de Francisco, ao mesmo tempo em que permanece um gestual "informal" no dirigir-se aos superiores religiosos, devido às relações pessoais de amizade com os líderes.

Além disso, esta necessidade de racionalização das regras e, por consequência, da autoridade, pareceu ser inseparável de uma "moralização" da religião, como podemos inferir já pela noção de crescimento espiritual. Como argumentei, os entrevistados não veem o poder do candomblé como uma força que pode ser utilizada ao bel prazer dos indivíduos. Ou melhor, embora o poder religioso possa ser voltado tanto para o bem quanto para o mal, eles concebem instâncias - os próprios orixás ou as "leis universais" - que regulam tal utilização, promovendo represálias contra aqueles que fazem mau uso da força do axé. Sustentei que este processo é imbricado no de racionalização, pois ambos constituem aspectos do mesmo esforço de sistematização de concepções e práticas. Podemos inferir, então, que este próprio esforço é orientado pelo habitus de classe média que constitui a matriz integradora de tais avaliações, predispondo seus portadores a certas interpretações da agência e à busca de uma sistematização lógica das normas que devem reger a vida humana. No entanto, é preciso não perder de vista a especificidade do contexto religioso em questão. No caso do candomblé, há mais um fator relevante a ser considerado na análise. Este esforço sistematizador, ao se voltar para o mundo proposto pela religião, deve envolver a negociação com todas as ca- 
tegorias de agentes o que, no presente caso, inclui levar em conta a vontade das entidades e a pressão que podem exercer sobre a ação humana. Entretanto, não chega a se formar uma contradição problemática, uma vez que as próprias divindades são vistas como portadoras de comportamentos moralizados, e alguns dos entrevistados chegam mesmo a apontar para as religiões éticas - no sentido weberiano de comportarem princípios abstratos e universais de separação entre o bem e o mal - como propagadoras de um "falso moralismo".

De toda sorte, procurei dar destaque a um ponto subjacente aos desenvolvidos posteriormente: considerar a ação humana implica levar em conta o mundo em que esta se desenrola o que, por sua vez, significa incorporar na análise os possíveis agentes. As concepções religiosas acerca do mundo, dos seres humanos e das divindades orientaram a exploração da compreensão dos processos de autoidentificação com o candomblé pelos quais passaram estas pessoas. Logo no início, retomei algumas proposições correntes nas Ciências Sociais acerca do universo religioso contemporâneo, apontado como pluralista e desinstitucionalizado, procurando mostrar novamente, a necessidade de nuançar tais categorizações. Por um lado, o pluralismo não é exclusividade das sociedades modernas. Por outro, os indivíduos que pesquisei sustentam ao mesmo tempo a concepção de religião como escolha própria e a necessidade de exclusivismo quanto ao vínculo às comunidades de culto. Desse modo, fica evidente a necessidade de considerar o mundo das práticas humanas não somente do ponto de vista institucional, mas também das práticas que o constituem. No caso do candomblé, este último ponto envolve diretamente as divindades, e as concepções acerca da relação destas com seus filhos formaram o ponto de partida para a exploração dos processos identitários desenvolvidos nos terreiros.

Assim, iniciei a análise pela noção de que os orixás são energias da natureza e que as pessoas são seus filhos por serem compostas por elementos dessas energias. Neste ponto considerei a possibilidade das divindades operarem como formas de classificação das pessoas, como 
estereótipos que permitem situar alguém desde os primeiros contatos. No entanto, procurei mostrar que identidades são processos contínuos que se desenrolam na interação com outros, o que exige, mais uma vez, a conjugação de vários níveis de análise. Ao tratar do aspecto relacional do processo destaquei, mais uma vez, a importância de considerar quem são os outros envolvidos nas relações dessas pessoas. Procurei expor brevemente as possibilidades da identificação com o candomblé em contextos sociais mais amplos, nos quais os adeptos de classe média relataram assumir uma postura próxima a dos militantes religiosos: declarar publicamente o pertencimento religioso. Mais uma vez, reiterei que, nesse sentido, a adesão religiosa pode operar como elemento de distinção para as pessoas investigadas. No entanto, suas identidades pessoais não se conformam apenas em torno do pertencimento ao grupo religioso - embora isto seja de extrema relevância - mas também em relação com os orixás pessoais.

Argumentei, então, pela necessidade de confrontar as concepções expressas acerca das divindades com noções amplamente difundidas, como a já mencionada ênfase na autonomia individual. Vimos como os próprios orixás, concebidos simultaneamente como o mais genérico - energias da natureza que compõem todo e qualquer ser humano - e mais particular - o orixá do iniciado, que tem nome próprio e reside no assentamento - correlacionam-se com um modo individualizado de voltar-se para o mundo e se engajar nas interações sociais. Como as próprias entidades espirituais ganharam um caráter altamente singularizado, até mesmo o processo iniciático, com seu potencial desindividualizador, pode ser apropriado segundo a ênfase na pessoa como agente de suas escolhas e projetos. Como argumentou Segato (1995) é preciso manter a dualidade entre individuação e referência externa quando tratamos da identificação com o candomblé.

Dar espaço para a noção de indivíduo enfatizada nas narrativas dos pesquisados, porém, não significa restringir os processos de autoidentificação ao âmbito da reflexividade, muito embora esta constitua um aspecto relevante, quando os sujeitos veem a si próprios 
como agentes de uma biografia que envolve uma série de "opções" pessoais. Desse ponto de vista, as divindades podem operar como referência na retomada reflexiva do próprio passado e da situação atual, constituindo também uma orientação nas projeções de futuro. De fato, é muito comum que membros do candomblé justifiquem suas ações e as de outros como influência dos donos de suas cabeças. No entanto, mais uma vez, procurei chamar atenção para o fato de que este não é um processo uniforme e os próprios entrevistados apontaram para outros níveis a serem considerados. Em suas explicitações acerca da autoidentificação com as divindades, muitas vezes surgiu a importância de como elas "atuam" em suas vidas, o que elas "podem fazer". Assim, eles indicaram a importância de se considerar a experiência, muitas vezes imediata, através da qual o deus se deixa "conhecer" pelo adepto, possibilitando sua identificação. Assim foi efetuado um retorno à questão da interpretação no qual as divindades deixaram de aparecer como "signos" constituídos - que permitem classificar - e surgiram como parte integrante no processo de identificação.

Entretanto, diversas vezes enfatizei o aspecto interacional dos processos de autoidentificação, o que exigiu uma análise mais detalhada das relações com as divindades num local concreto de ação: o terreiro. Assim, elementos rituais, já explicitados no capítulo 4 com relação às possibilidades de singularização da posição individual, foram retomados e analisados mais detidamente. Aqui o acento foi um pouco modificado ${ }^{109}$ e a individualização foi referida mais explicitamente às diversas articulações religiosas da identidade que o candomblé pode oferecer. Os orixás foram, num dado momento, considerados como elementos cognitivos de interpretação de si e dos outros e, em outro, como agentes no mundo religioso. A partir desse

109 Não apenas as falas dos entrevistados podem revelar novos sentidos quando confrontadas com abordagens teóricas distintas, mas também as análises acadêmicas apresentam esta multivocidade quando em diálogos com perspectivas diferentes, como podemos ver aqui. 
ponto a própria experiência das divindades surgiu como resultado da constituição do entorno da ação em termos específicos.

Contudo, o olhar dirigido especialmente para o contexto ritual evidenciou ainda outros aspectos relevantes. Em primeiro lugar, que as identidades pessoais constituídas em relação com o candomblé devem ser atuadas e reconhecidas publicamente no contexto especificamente religioso. Como vimos, uma das particularidades desse contexto é a manutenção de uma série de dualidades. Em segundo lugar, que os processos identitários são articulados em longos percursos que configuram trajetórias religiosas internas ao grupo, marcadas pelas obrigações que reforçam os vínculos com o axé e pelos degraus hierárquicos alcançados. Em terceiro lugar, que é imprescindível considerar a convivência na roça e, portanto, a presença encarnada dos sujeitos no ambiente religioso. Tratar o objeto aqui proposto considerando a condição fundamentalmente incorporada da ação humana significa procurar iluminar o próprio processo pelo qual se dá a abertura a novas disposições e sua relação com a continuidade.

Dessa forma, procurei analisar detidamente eventos e situações a partir dos quais foi possível enfatizar a dimensão incorporada de significados e sentidos emergentes nas interações. Mais uma vez, a proposição de diferentes perspectivas que se somam permitiu evidenciar a instabilidade dos sentidos, como no caso das dificuldades na relação com a hierarquia, por exemplo. As disposições do habitus puderam, então, ser retratadas como horizonte da ação presente, ou seja, como pano de fundo e não como condicionamento da prática. Foi possível, assim, ressaltar algumas peculiaridades de uma posição de classe que não situa de uma vez por todas os agentes, tampouco pode ser completamente transcendida na incorporação de novas disposições. A inadequação do habitus existente às exigências da interação surge como possibilidade de reflexividade acerca da própria situação. Esta reflexão, no entanto, é posicionada em relação às mesmas disposições que a possibilitam. No entanto, há um processo que se desenrola no tempo e a aquisição de gestos, posturas, avalia- 
ções e percepções consiste exatamente na capacidade de recorrer a eles sem necessidade de tematização. Neste sentido, a convivência no terreiro possibilita uma verdadeira ampliação de horizontes para os novos adeptos: estes passam a contar com as formas de voltar-se para o mundo propostas pelo candomblé. Desta forma, pode-se dizer que a inserção num terreiro envolve os processos autoidentitários oferecendo-lhes elementos reflexivos à retomada da própria vida e também exigindo um engajamento corporal nas situações concretas.

No entanto, a própria religião não pode ser tomada como objeto estanque e constituído. Também ela é histórica. Assim, sugeri, brevemente, o interesse de uma possível comparação com outras análises que consideram a incorporação por espíritos e ancestrais como modo de relação com a história. Isto evidencia que, como participantes de um mundo humano, as próprias divindades são constituídas nos modos do sujeito de voltar-se para seu entorno. Nesse sentido, também elas emergem de uma espécie de hermenêutica da experiência imediata que se dá sobre o horizonte dos envolvidos. Desta forma, no caso particular do terreiro onde foi realizado o trabalho de campo, os deuses apresentam características comuns com os modos de engajamento no mundo, surgindo como simultaneamente individualizados e generalizados a toda a humanidade. Este, porém, é um âmbito no qual se entrecruzam todas as especificidades possíveis e que pode constituir um objeto de análise por si só e que exigiria uma investigação acerca de concepções particulares de ancestralidade e sua correlação com diferentes classes sociais, com o fenótipo negro e terreiros de idades e tradições diversas. Como indiquei, a intenção no presente estudo era analisar correlações entre uma posição de classe e uma religião particular e, portanto, apenas pude indicar que o ponto de vista inclusivo que propus favorece a contínua emergência de novos temas e objetos de pesquisa, ao invés de esgotá-los.

Se o que chamei de "lógica do candomblé" (a manutenção de dualidades, uma lógica do "e”, não do “ou”) condicionou minha abordagem teórica ou esta condicionou minha visão da religião é im- 
possível dizer. Talvez ambos simultaneamente. De toda forma, posso dizer que procurei construir uma análise compreensiva, seguindo uma perspectiva em muito marcada pelas posições teóricas weberianas, uma vez que, no fundo, diz respeito ao sentido da ação. Contudo, procurei revelar maneiras como este sentido está profundamente imbricado no mundo concreto em que esta ação ocorre na forma de interação com outros, sejam estes humanos ou divindades. 


\section{Referências}

AGIER, M. Mobilidades: algumas formas recentes de diferenciação social. In: GUIMARÃES, A. M.; AGIER, M.; CASTRO, N. A. Imagens e identidades do trabalho. São Paulo: Hucitec, 1995. p. 75-112.

AGIER, M.; CASTRO, N. A. Projeto operário, projetos de operários. In:

GUIMARÃES, A. M.; AGIER, M.; CASTRO, N. A. Imagens e identidades do trabalho. São Paulo: Hucitec, 1995. p. 113-148.

AGIER, M.; GUIMARÃES, A. S. A. Técnicos e peões: a identidade ambígua. In: GUIMARÃES, A. M.; AGIER, M.; CASTRO, N. A. Imagens e identidades do trabalho. São Paulo: Hucitec, 1995. p. 39-74.

ALBUQUERQUE, J. A. G. Classe média: caráter, posição e consciência de classe. In: ALBUQUERQUE, J. A. G. (Org.). Classes Médias e Política no Brasil. Rio de Janeiro: Paz e Terra, 1977.

ALMEIDA, P. H. de. Quanto vale um diploma de graduação em Salvador? Bahia Análise \& Dados Dez Anos da PED, Salvador, v. 15, n. 14, p. 527-536, 2006.

AMARAL, R. de C. Xire! O modo de crer e viver no Candomblé. Rio de Janeiro: Pallas, 2002.

AMARAL, R. de C.; SILVA, V. G. da. A cor do axé: brancos e negros no Candomblé de São Paulo. Estudos Afro-Asiáticos, Rio de Janeiro, n. 25, p. 99-124, 1993.

ARAÚJO, B. J. de. Mudanças na estrutura social brasileira. In: ALBUQUERQUE, J. A. G. (Org.). Classes médias e política no Brasil. Rio de Janeiro: Paz e Terra, 1977. 
AUGRAS, M. O duplo e a metamorfose: a identidade mítica em comunidades nagô. Petrópolis, RJ: Vozes, 1983.

BAPTISTA, J. R. de C. Amigos, amigos, negócios à parte... Mas nem tanto assim: uma abordagem preliminar sobre as relações entre clientela e saúde no Candomblé. In: MANDARINO, A. C. de S.; GOMBERG, E. (Org.). Leituras afro-brasileiras: territórios, religiosidades e saúdes. Salvador: EDUFBA; São Cristóvão: UFS, 2009. p. 241-261.

BÁRBARA, R. S. A dança sagrada do vento. In: MARTINS, C.; LODY, R. (Org.). Faraimará: o caçador traz alegria: Mãe Stella: 60 anos de iniciação. Rio de Janeiro: Pallas, 2000. p. 150-166.

BASTIDE, R. As religiões africanas no Brasil. São Paulo: Pioneira, 1971.

BASTIDE, R. Cavalo dos santos. Esboço de uma sociologia do transe. Estudos Afro-brasileiros, São Paulo: Perspectiva, 1983. p. 223-323.

BASTIDE, R. Le príncipe d'individuation (contribuition à une filosophie africaine). In: COLLOQUES INTERNATIONAUX DU C N R S LA NOTION DE PERSONE EN AFRIQUE NOIR, 1973, Paris. Colloque... Paris: Editions du C.N.R.S., 1973.

BASTIDE, R. O candomblé da Bahia. São Paulo: Companhia das Letras, 2001.

BIRMAN, P. 0 campo da nostalgia e a recusa da saudade: temas e dilemas dos estudos afro-brasileiros. Religião e Sociedade, Rio de Janeiro, v. 18, n. 2, p. $75-122,1997$.

BOURDIEU, P. Condição de classe e posição de classe. In: BOURDIEU, P. A Economia das Trocas Simbólicas. São Paulo: Perspectiva, 1999. p. 3-25.

BOURDIEU, P. Distinction: a Social critique of the judgement of taste. London: Routledge, 2003.

BOURDIEU, P. Marginália: algumas notas adicionais sobre o dom. Mana: estudos de antropologia social, Rio de Janeiro, v. 2, n. 2, p. 7-20, 1996.

BOURDIEU, P. O conhecimento pelo corpo. In: BOURDIEU, P. Meditações pascalianas. Rio de Janeiro: Bertrand Brasil. 2001a. p. 157-198.

BOURDIEU, P. Razões práticas: sobre a teoria da ação. 3. ed. Campinas, SP: Papirus Editora. 2001b.

BOURDIEU, P. Sistemas de ensino e sistemas de pensamento. In: BOURDIEU, P. A economia das trocas simbólicas. São Paulo: Perspectiva, 1999b. p. 203-229. BRAGA, J. A cadeira de Ogã: e outros ensaios. Rio de Janeiro: Pallas, 1999. 
BRAGA, J. Fuxico de candomblé. Feira de Santana: Uefs, 1998.

BRAGA, J. O culto de Egun em Ponta de Areia, Itaparica. In: REIS, J. J. (Org.). Escravidão e invenção da liberdade: estudos sobre o negro no Brasil.

São Paulo: Brasiliense, 1988a. p. 198-214.

BRAGA, J. O jogo de búzios: um estudo da adivinhação no candomblé. São Paulo: Brasiliense, 1988b.

BRANDÃO, C. R. A crise das instituições tradicionais produtoras de sentido. In: MOREIRA, A.; ZICMAN, R.; BRANDÃO, C. R. (Org.). Misticismo e novas religiões. 2. ed. Petrópolis, RJ: Vozes, 1994. p. 23-41.

BUDGEON, S. Identity as Embodied Event. Body \& Society, New Delhi, v. 9, n. 1, p. 35-55, 2003. Quarterly.

CAILLÉ, A. Nem holismo nem individualismo metodológicos. Marcel Mauss e o paradigma da dádiva. Revista Brasileira de Ciências Sociais, São Paulo, v. 13, n. 38, p. 5-35, 1998.

CAMPOS, Vera Felicidade de A. Estruturação de atitudes - individualidade cultural. In: MARTINS, C.; LODY, R. (Org.). Faraimará: o caçador traz alegria: mãe Stella: 60 anos de iniciação. Rio de Janeiro: Pallas, 2000. p. 167-173.

CARNEIRO, E. Candomblés da Bahia. 8. ed. Rio de Janeiro: Civilização Brasileira, 1991.

CASTRO, N. A.; BARRETO, V. S. Os negros que dão certo. In: CASTRO, N. A.; BARRETO, V. S. (Org.). Trabalho e desigualdades raciais: negros e brancos no mercado de trabalho de Salvador. São Paulo: Annablume, 1998. p. 131-157.

CASTRO, N. A. Trabalho e desigualdades raciais: hipóteses desafiantes e realidades por interpretar. In: CASTRO; BARRETO. (Org.). Trabalho e desigualdades raciais: negros e brancos no mercado de trabalho de Salvador. São Paulo: Annablume. 1998. p. 22-40.

CASTRO, N. A.; GUIMARÃES, A. S. A. Classe proletária, trabalhadores prósperos. In: GUIMARÃES, A. S. A.; AGIER, M.; CASTRO, N. A. Imagens e identidades do trabalho. São Paulo: Hucitec, 1995. p. 19-38. (Ciências Sociais, 35).

CLIFFORD, J. Partial truths. In: CLIFFORD, J.; MARCUS, G. E. Writing Culture: the poetics and politics of ethnography. Berkeley: University of California Press, 1986. p. 1-26.

CRAPANZANO, V. Introduction to Case Studies of Spirit Possession. In: CRAPANZANO, V.: GARRISON, V. (Org.). Case Studies of Spirit Possession. New York: John Wiley, 1977. p. 1-40. 
CSORDAS, T. J. Body / Meaning / Healing. New York: Palgrave Macmillan, 2002.

CSORDAS, T. J. The Sacred Self: cultural phenomenology of charismatic healing. Berkeley: University of California Press, 1994.

DANTAS, B. G. Vovó nagô e papai branco: usos e abusos da África no Brasil. Rio de Janeiro: Graal, 1988.

FERRÁNDIZ, F. M. The Body as Wound: Possession, Malandros and everyday violence in Venezuela. Critique of Anthropology, New Delhi, v. 24, n. 2, p. 107$133,2004$.

FIGUEIREDO, ÂA. A classe média negra não vai ao paraíso: raízes, trajetórias e identidade entre os empresários negros. 2003. Quantidade de folhas. Tese (Doutorado) - Instituto Universitário de Pesquisa do Rio de Janeiro, Rio de Janeiro, 2003.

FRIGERIO, A. Por nuestros derechos, ahora o nunca!: Construyendo una identidad colectiva umbandista en Argentina. Civitas: Revista de Ciências Sociais, Porto Alegre, v. 1, n. 3, p. 35-68, jun. 2003.

FRIGERIO, A. El estudio de la religión desde la perspectiva de los movimientos sociales: Sus aportes ao análisis de la construcción de identidades religiosas. In: ENCONTRO ANUAL DA ANPOCS, 26., 2002, Caxambu. Anais... Caxambu, 2002. p. 2-18.

GEERTZ, C. El antropólogo como autor. Barcelona: Ediciones Paidos, 1989.

GIDDENS, A. Modernity and self-identity: Self and society in the late modern age. Stanford: Stanford University press, 1991.

GOFFMAN, E. A representação do Eu na vida cotidiana. 8. ed. Petropólis, RJ: Vozes. 1999.

GOFFMAN, E. Estigma: Notas sobre a manipulação da identidade deteriorada. 4. ed. Rio de Janeiro: Guanabara, 1988. (Antropologia Social).

GOLDMAN, M. A construção ritual da pessoa: a possessão no candomblé. Religião e Sociedade, Rio de Janeiro, v. 1, n. 12, p. 22-55, Ago. 1985.

GONZAGA, L. L. Diferenças e semelhanças do mercado de trabalho nas regiões metropolitanas de Salvador e de São Paulo. Bahia Análise \& Dados, Salvador, v. 15, n. 4, p. 443-449, 2006. (Número especial dez Anos da PED).

GORDILHO, Â. Limites do habitar: segregação e exclusão na configuração urbana de Salvador e perspectivas no final do século XX. Salvador: Edufba, 2000. 
GUIMARÃES, A. M.; AGIER, M.; CASTRO, N. A. Imagens e identidades do trabalho. São Paulo: Hucitec, 1995.

GUIMARÃES, A. S. A ilusão do atalho: a experiência operária da pequena burguesia em descenso. In: GUIMARÃES, A. S.; AGIER, M.; CASTRO, N. A. Imagens e identidades do trabalho. São Paulo: Hucitec, 1995. p. 149-180.

GUIMARÃES, A. S.; AGIER, M.; CASTRO, N. A. Introdução. In: GUIMARÃES, A. S.; AGIER, M.; CASTRO, N. A. Imagens e identidades do trabalho. São Paulo: Hucitec, 1995. p. 9-18.

GUIMBELLI, E. O "baixo espiritismo" e a história dos cultos mediúnicos. Horizontes Antropológicos, Porto Alegre, ano 9, n. 19, p. 247-281, jul. 2003. HALPERIN, D. Memória e "consciência" em uma religião afro-brasileira: o Tambor de Mina do Maranhão. Religião e Sociedade, Rio de Janeiro, v. 19, n. 2, p. 77-102, 1999.

HERITAGE, J. Garfinkel and Ethnomethodology. New York: Polity Press, 1984. HERVIEU-LÉGER, D. The transmission and the formation of the socioreligious identities in modernity: an analytical essay on the trajectories of identification. International Sociology, New Delhi, v. 13 n. 2, p. 213-228, 1998.

IBGE. Cidades@, Salvador, (c)2014. Disponível em: < http://cod.ibge.gov. br/232MX >. Acesso em: 5 jan. 2012.

IBGE. Pesquisa mensal de emprego. Salvador, 2011. Disponível em: <http:// www.ibge.gov.br/home/estatistica/indicadores/trabalhoerendimento/pme_ nova/pme_201111ba_01.shtm>. Acesso em: 6 jan. 2012.

IBGE. Síntese de indicadores sociais: uma análise das condições de vida da população brasileira. Rio de Janeiro, 2010. (Estudos e Pesquisas Informação Demográfica e Socioeconômica, 27).

JENKINS, R. Categoriation: Identity, Social Process and Epistemology. Current Sociology, New Delhi, v. 48, n. 3, p. 7-25, out. 2000.

JENKINS, R. In the present tense: Time, identification and human nature. Anthropological Theory, New Delhi, v. 2, n. 3, p. 267-280, 2002.

LAMARQUE, P. On not expecting too much from narrative. Mind \& Language, Oxford, v. 19, n. 4, p. 293-480, 2004.

LEWIS, I. M. Exxtase religioso: um estudo antropológico da possessão por espírito e do xamanismo. São Paulo: Perspectiva, 1977. 
LIMA, V. da C. A família de santo nos candomblés jeje-nagôs da Bahia: estudos de relações inter-grupais. 2. ed. Salvador: Corrupio, 2003.

MARIZ, C. L.; MACHADO, M. das D. C. Changements récents dans le champs religieux brésilien. Social Compass, New Delhi, v. 45 n. 3, p. 359-378, 1998.

MATTINGLY, C. Healing dramas and clinical plot: the narrative strutucture of experience. New York: Cambridge University Press, 1998.

MAUÉS, R. H. "Bailando com o Senhor": técnicas corporais de culto e louvor (o êxtase e o transe como técnicas corporais). Revista de Antropologia, São Paulo, v. 46, n.1, p. 10-40, 2003.

MAUSS, M. Uma categoria do espírito humano: a noção de pessoa, a noção de eu. In: MAUSS, M. Sociologia e Antropologia. São Paulo: Cosac Naify, 2003a, p. 367-397.

MAUSS, Marcel. Ensaio sobre a dádiva: forma e razão da troca nas sociedades arcaicas. In: MAUSS, M. Sociologia e Antropologia. São Paulo: Cosac Naify, 2003b, p. 183-314.

MCCALLUM, C. Resisting Brazil: Perspectives on Local Nationalisms in Salvador da Bahia. Ethnos, Stockholm, v. 61, n. 3-4, p. 207-229, 1996.

MCNAY, L. Gender, habitus and the field: Pierre Bourdieu and the limits of reflexivity. Theory, Culture and Society, New Delhi, v. 16, n. 1, p. 95-117, 1999.

MERLEAU-PONTY, M. Phenomenology of Perception. New York: Humanity Press, 1962.

NEGRÃO, L. N. Refazendo antigas e urdindo novas tramas: trajetórias do sagrado. Religião e Sociedade, Rio de Janeiro, v. 18, n. 2, p. 63-74, 1997.

NICOLAU-PARÉS. L. The Phenomenology of Spirit Possession in the Tambor de Mina (An ethnographic and audio-visual study). 1986. Tese (Doutorado) University of London, London, 1997.

O'DOUGHERTY, M. Auto-retratos da classe média: hierarquias de "cultura" e consumo em São Paulo. Dados, Rio de Janeiro, v. 41, n. 2, p. 411-444, 1998.

ORO, A, P. As relações raciais nos terreiros do Rio Grande do sul. Estudos Afro-Asiáticos, Rio de Janeiro, n. 33, p. 31-50, 1998.

PEIXOTO, F. A. Diálogos Afro-Brasileiros: uma Análise da Obra de Roger Bastide. São Paulo: EDUSP, 2000. 
PIERUCCI, A. F. Religião como solvente uma aula. Novos Estudos, São Paulo, n. 75, p. 111-127, jul. 2006.

PIERUCCI, A. F. Secularização em Max Weber: da contemporânea serventia de voltarmos a acessar aquele velho sentido. Revista Brasileira de Ciências Sociais, São Paulo, v. 13, n. 37, p. 43-73, 1998.

PRANDI, R. Converter indivíduos, mudar culturas. Tempo Social: revista de sociologia da USP. São Paulo, v. 20, n. 2, p. 155-172, 2008.

PRANDI, R. Mitologia dos Orixás. São Paulo: Companhia das Letras, 2001.

PRANDI, R. Referências sociais das religiões afro-brasileiras: sincretismo, branqueamento, africanização. In: CAROSO, C.; BACELAR, J. A. (Org.). Faces da tradição afro-brasileira: religiosidade, sincretismo, anti-sincretismo, reafricanização práticas terapêuticas, etnobôtanica e comida. Rio de Janeiro: Palas; Salvador: CEA0; Brasilia, DF: CNPq, 1999. p. 93-111.

PRANDI, R. Os Candomblé de São Paulo: a velha magia na Metropole Nova. São Paulo: Hucitec: EDUSP, 1991.

RABELO, M. C. Entre a casa e a roça: trajetórias de socialização no Candomblé de habitantes de bairros populares em Salvador. Religião e Sociedade, Rio de Janeiro, v. 28, n. 1, 176-205, 2008a.

RABELO, M. C. et al. Comparando experiências de aflição e tratamento no candomblé, Pentecostalismo e Espiritismo. Religião e Sociedade, Rio de Janeiro, v. 22, n. 1, p. 93-121, 2002.

RABELO, M. C. Merleau-Ponty e as Ciências Sociais: corpo, sentido e existência. In: VALVERDE, M. (Org.). Merleau-Ponty em Salvador. Salvador: Arcádia, 2008b, p. 107-130.

RABELO, M. C. Rodando com o santo e queimando no espírito: possessão e a dinâmica de lugar no Candomblé e Pentecostalismo. Ciencias Sociales y Religión, Porto Alegre, v. 7, n. 7, p. 11-37, 2005.

REIS, J. J.; SILVA, E. Nas malhas do poder escravagista: a invasão do candomblé do Accú. In: REIS, J. J.; SILVA, E. Negociação e conflito: a resistência negra no Brasil escravista. São Paulo: Companhia das Letras, 1989. p. 32-61.

ROUGET, G. Trance and possession. In: ROUGET, G. Music and Trance: a theory of the relations betweeen music and possession. Chicago: the University of Chicago Press, 1985. p. 3-62. 
SANSI, R. Fetishes \& Monuments: Afro-Brazilian art and culture in the twentieth century. New York: Berghahn Books, 2007. (Remapping cultural history, 6).

SANSI, R. Fetishes, Images, Commodities, Art Works: Afro-Brazilian Art and culture in Bahia. 2003. 599 f. Tese (Doutorado) - University of Chicago, Chicago, 2003.

SANSONE, L. Não-trabalho, consumo e identidade negra: uma comparação entre Rio e Salvador. In: MAGGIE, Y.; REZENDE, C. B. (Org.). Raça como retórica: a construção da diferença. Rio de Janeiro: Civilização Brasileira, 2001. p. 157-182.

SANSONE, L. Os objetos da identidade negra: consumo, mercantilização, globalização e a criação de culturas negras no Brasil. Mana, Rio de Janeiro, v. 6, n. 1, p. 87-119, 2000.

SANTOS, J. E. dos. Os Nagô e a morte: Pade, Asese e o culto Egun na Bahia. 3. ed. Petrópolis, RJ: Vozes, 1984.

SANTOS, J. T. dos. O dono da terra: o caboclo nos candomblés da Bahia. Salvador: SarahLetras, 1995.

SANTOS, J. T. dos. O poder da cultura e a cultura no poder: a disputa simbólica da herança cultural negra no Brasil. Salvador: Edufba, 2005.

SANTOS, M. das G. V. Redes sociais e saúde mental num terreiro de candomblé. 2003. Dissertação (Mestrado) Universidade Federal de Bahia, Salvador, 2003.

SCHAWRCZ, L. M. O espetáculo das raças: cientistas, instituições e questão racial no Brasil 1870-1930. São Paulo: Companhia das Letras, 1995.

SEGATO, R. L. Santos e daimones: o politeísmo afro-brasileiro e a tradição arquetipal. Brasília, DF: UnB, 1995.

SILVA, V. G. da. O antropólogo e sua magia: trabalho de campo e texto etnográfico nas pesquisas antropológicas sobre as religiões afro-brasileiras. São Paulo: Edusp, 1998.

SILVA, V. Reafricanização e sincretismo: interpretações acadêmicas e experiências redigiosas. In: CAROSO, C.; BACELAR, J. (Org.). Faces da tradicão afro-brasileira: religiosidade, sincretismo, anti-sincretismo, práticas terapêuticas, etnobotânica e comida. Rio de Janeiro: Pallas; Salvador: CEAO, 1999.

SILVERSTEIN, L. Mãe de todo o mundo: modos de sobrevivência nas comunidades de candomblé da Bahia. Religião e sociedade, Rio de Janeiro, n. 4, p. 143-169, 1979. 
STOLLER, P. Embodying colonial memories. In: STOLLER, P. Sensuous Scholarship. Philadelphia: University of Pennsylvania Press, 1997. p. 48-73. STOLLER, P. Fusion of the Worlds: an ethnography of possession among the Songhay of Niger. Chicago: The University of Chicago Press, 1989.

TURNER, V. W. O processo ritual: estrutura e antiestrutura. Petrópolis: Vozes, 1974. VELHO, G. A utopia urbana: um estudo de Antropologia Social. 5. ed. Rio de Janeiro: J. Zahar, 1989.

VELHO, G. Individualismo e cultura: notas para uma antropologia da sociedade conteporanea. Rio de Janeiro: J. Zahar, 1981. (Antropologia social).

VERGER, P. Orixás: deuses iorubás na África e no novo mundo. 6. ed. Salvador: Corrupio, 2002b.

VERGER, P. Papel exercido pelo estado de torpor durante a iniciação dos noviços ao culto dos Orixás e Voduns. In: MOURA, C. E. M. de. (Org.). Saída de laô: cinco ensaios sobre a religião dos orixás. São Paulo: Axis Mundi, 2002a.

WEBER, M. A Ética protestante e o espírito do capitalismo. São Paulo: Companhia das Letras, 2004.

WEBER, M. A objetividade do conhecimento nas Ciências Sociais. São Paulo: Ática, 2006. (Ensaios Comentados).

WEBER, M. A psicologia social das religiões mundiais. In: GERTH, H. H.; MILLS, W. (Org.). Ensaios de Sociologia. Rio de Janeiro: J. Zahar, 1974b. p. 309-346.

WEBER, M. Classe, estamento, partido. In: GERTH, H. H.; MILLS, W. (Org.). Ensaios de Sociologia. Rio de Janeiro: J. Zahar. 1974a. p. 211-228.

WEBER, M. Conclusions: Confucianism and puritanism. In: WEBER, M. The Religion of China: confucianism and Taoism. New York: Free Press, 1968. p. 226-249.

WEBER, M. Rejeições religiosas do mundo e suas direções. In: GERTH, H. H.; MILLS, W. (Org.). Ensaios de Sociologia. Rio de Janeiro: J. Zahar. 1974c. p. 371-410.

WEBER, M. Sociologia da religião (tipos de relações comunitárias religiosas). In: WEBER, M. Economia e sociedade: fundamentos da sociologia compreensiva. Brasília: Unb, 1991. p. 249-418.

WEBER, M. The Religion of India: the Sociology of Hinduism and Buddhism. New Delhi: Munshiram Manoharlal Publishers, 1996.

WEISS, G. Body Image: embodiment as intercorporeality. New York: Routledge, 1999. 
COLOFÃO

\author{
Formato $\quad 17 \times 24 \mathrm{~cm}$ \\ Tipografia Leitura Sans/Leitura News \\ Papel Alcalino $75 \mathrm{~g} / \mathrm{m}^{2}$ (miolo) \\ Cartão Supremo 300 g/m² (capa) \\ Impressão Edufba \\ Tiragem 300 exemplares
}

Capa e Acabamento Cartograf 